ELIZABETH DE SOUZA MACHADO-HESS

\title{
UMA PROPOSTA METODOLÓGICA PARA A ELABORAÇÃO DE ATLAS ESCOLARES PARA OS ANOS INICIAIS DO ENSINO FUNDAMENTAL: O EXEMPLO DO MUNICÍPIO DE SOROCABA - SP
}

Versão Corrigida 


\section{UMA PROPOSTA METODOLÓGICA PARA A ELABORAÇÃO DE ATLAS ESCOLARES PARA OS ANOS INICIAIS DO ENSINO FUNDAMENTAL: O EXEMPLO DO MUNICÍPIO DE SOROCABA - SP}

Tese apresentada ao Programa de Pós-graduação em Geografia Humana do Departamento de Geografia da Faculdade de Filosofia, Letras e Ciências Humanas, da Universidade de São Paulo para a obtenção do título de Doutora em Geografia Humana.

Área de concentração: Geografia Humana

Orientador: Prof. Dr. Marcello Martinelli.

Versão Corrigida

De acordo,

Prof. Dr. Marcello Martinelli

São Paulo

2012 
Catalogação na Publicação

Serviço de Biblioteca e Documentação

Faculdade de Filosofia, Letras e Ciências Humanas da Universidade de São Paulo

M151p MACHADO-HESS, Elizabeth de Souza

Uma proposta Metodológica para a Elaboração de

Atlas Geográficos Escolares (Anos Iniciais do

Ensino Fundamental): O Exemplo do Município de

Sorocaba (SP) / Elizabeth de Souza Machado-Hess ;

Orientador Dr. Marcello Martinelli. - São Paulo, 2012.

$225 \mathrm{f}$.

Tese (Doutorado) - Faculdade de Filosofia, Letras

e Ciências Humanas da Universidade de São Paulo.

Departamento de Geografia. Área de concentração:

Geografia Humana.

1. Geografia. 2. Educação. 3.Cartografia

4. Atlas Escolar Sorocaba-SP. I. Martinelli, Marcello, Orient. II. Título.

CDU : $912(815.6)$

CRB1552 - Mônica M.S.M.Nunes 
Dedico este trabalho aos alunos e professoras das Escolas Estaduais Baltazar Fernandes e Brigadeiro Tobias. 
Mas os que esperam no senhor renovarão as suas forças, subirão com asas como águias, correrão e não se cansarão, caminharão e não se fatigarão. Isaías 40:31 
Ao meu pai Luiz (in memoriam) pelo seu exemplo de humildade e gratidão. À minha mãe Elza Machado, exemplo de vida! 
A todos os meus irmãos e irmãs que apesar da distância estão sempre presentes em meus pensamentos! 
Ao Tarcpai, meu marido, por sua constante e carinhosa dedicação à família. Aos meus amados filhos Tarcfilho e Helena que me deram força para a concretização deste trabalho. 


\section{AGRADECIMENTOS}

Ao professor Dr. Marcello Martinelli pela dedicada orientação durante todas as etapas desta Tese de Doutorado. Orientação que me fez crescer como pessoa e profissional.

Ao Presidente do Instituto Histórico, Geográfico e Genealógico de Sorocaba e professor Adilson Cezar pela notória contribuição para o conhecimento da História de Sorocaba.

Ao Diretor da Área de Geoprocessamento e Cadastro Técnico - AGCT. Secretaria de Habitação e Urbanismo - SEHAB da Prefeitura de Sorocaba, senhor Isalberto Boff

Aos Srs. Samuel F. Leite e José Manoel Guerreiro - Núcleo de Informação da Secretaria da saúde.

Às professoras da família Machado: Elza, Maria Bernarda, Raquel e Mônica Maria fonte de inspiração.

À Diretora Eliane e vice-diretora Darly (vice-diretora) da Escola Estadual Baltazar Fernandes.

Ao diretor Sérgio Armênio e Coordenadora Pedagógica Lindinéia da Escola Estadual Brigadeiro Tobias.

À professora e amiga Maria Cristina Lopes, exemplo de educadora a se seguir.

Ao meu cunhado Marcus Glay que com sua câmara fotográfica ao registrar fragmentos de uma realidade, acabou por refletir o seu próprio olhar.

À bibliotecária Mônica Maria pela cuidadosa revisão das referências e normalizações, o meu sincero agradecimento.

À professora Erineuza de Jesus que acompanhou de perto todos os momentos da pesquisa.

A todos os que já foram meus alunos que através de suas indagações, em meio às aulas, chamaram-me a atenção para a importância de um trabalho desse gênero.

Aos meus sobrinhos Bruna Monique, João Pedro e Maria Júlia que acompanharam todo o processo.

Ao corpo profissional da Secretaria de Pós-Graduação do Departamento de Geografia - FFLCH.

Ao CNPq pela concessão de bolsa de estudo pelo período de 2 anos

A todos que de alguma forma participaram e contribuíram para a concretização desta Tese. 
Vejo as ruas de perto, não vejo as de longe.

No mapa posso ver como a foto de mamãe quando não está aqui.

O mapa é um desenho que faz pequeno os lugares, para os pequenos ver o mundo grande.

Como eu faço pequeno o desenho de mamãe e papai que para mim são do tamanho do mundo.

Humberto Machado 


\section{RESUMO}

No período correspondente à última década do século $\mathrm{XX}$ até o momento atual, observa-se que a Educação Básica no Brasil e, mais especificamente, o Ensino Fundamental, experimentou alguns avanços, em virtude de ações governamentais, visando a melhoria da qualidade da Educação nos seus diferentes níveis. No entanto, apesar destes avanços, as políticas educacionais no Brasil ainda se caracterizam pela descontinuidade e centralização. Dentro do cenário nacional, também é objeto de preocupação a qualidade da formação dos professores, bem como a sua preparação para ensinar o conteúdo previsto no currículo e, não menos importante, a verificação da aprendizagem dos alunos formados.

Neste contexto, os Atlas Escolares surgem como recursos didáticos de apoio, que aliados às práticas de alfabetização cartográfica e aos exercícios em sala, permitem viabilizar o ensino/aprendizagem do conteúdo previsto de Geografia para cada ano do Ensino Fundamental.

Ao propor uma metodologia para a elaboração de Atlas Escolares para o conhecimento do local, esta Tese retoma a questão de se produzir recursos didáticos e sugerir práticas de ensino que sejam adequadas tanto para professor quanto para o aluno.

Portanto, são objetivos deste trabalho: propor uma metodologia para a elaboração de Atlas Escolares para o conhecimento do local; aplicar a metodologia proposta, mediante a implementação de um protótipo de Atlas Escolar para o município de Sorocaba-SP; avaliar a adequação do Protótipo em sala de aula.

Palavras-chave: Geografia. Educação. Cartografia. Atlas escolar. Sorocaba-SP. 


\begin{abstract}
During the last decade of the 20th century until the present day, one can notice that the Basic Education in Brazil and, more specifically, the Elementary School, has experienced some advances, due to government actions, seeking the improvement of the quality of Education among its different levels. However, despite of the advances, educational politics in Brazil are still characterized by the discontinuity and centralization. Inside this national scenario, the quality of the teachers' formation is still a major concern, as well as their preparation to teach the curriculum contents and, not less important, the student learning verification.
\end{abstract}

In this context, School Atlases arise as didactic support resources, that allied to cartographic initiation practices and classroom exercises, allow the teaching/learning achievement of the Geography contents for each grade in the Elementary School.

By proposing a methodology to produce School Atlases for the local knowledge, this Doctoral Dissertation focuses on the issue of producing didactic resources and suggests teaching practices that are adequate not only for the teacher but also for the students.

Therefore, these are the goals of this work: to propose a methodology for producing School Atlases for the local knowledge; to apply the proposed methodology through the implementation of a prototype of School Atlases for the city of Sorocaba (SP); to evaluate the adequacy of the prototype in the classroom environment.

Keywords: Geography. Education. Cartography. Student Atlas. Sorocaba-SP. 


\section{LISTA DE ILUSTRAÇÕES}

FIGURA 1 - Organograma da interação entre a Geografia, Educação e

Cartografia

FIGURA 2 - Frontispício do Atlas de Mercator.

FIGURA 3 - Cartograma da população do Brasil - 2000 …………........................90

FIGURA 4 - Anamorfose da população do Brasil - 2000........................................90

FIGURA 5 - A transcrição gráfica das relações entre objetos..................................93

FIGURA 6 - As principais variáveis visuais da imagem e de separação....................93

FIGURA 7 - Os diferentes níveis da análise espacial.......................................103

FIGURA 8 - Modelo explicativo das dimensões escalares: totalidade-mundo.........105

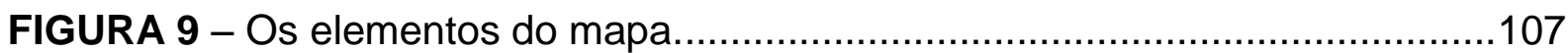

FIGURA 10 - Região Administrativa de Sorocaba............................................120

FIGURA 11 - Mapa político do Município de Sorocaba........................................120

FIGURA 12. Exemplo de uma Prancha Temática - Mapa do Município de SorocabaSP. 125

FIGURA 13 - Fluxograma da metodologia seguida para avaliação dos capítulos do Protótipo do atlas escolar. 133

FIGURA 14 - Atividade: Lateralidade (a) e (b). Carimbo da mão esquerda e da direita; do pé esquerdo e do direito. Alunos do $2^{\circ}$ ano, turma "A".

FIGURA 15 - Mapa do corpo da criança (a) e (b). Atividade desenvolvida pelos alunos do $2^{\circ}$ ano, turma "A".

FIGURA 16 - Maquete da sala de aula feita por alunos do $3^{\circ}$ ano, turma "C". Visão frontal (a), Visão Oblíqua (b) e Visão Vertical (c)

FIGURA 17 - Passagem da Maquete para a Planta da sala de aula (a) e (b). Atividade executada pelos alunos do $3^{\circ}$ ano, turma "C". 159

FIGURA 18 - Atividade em grupo dos alunos do $5^{\circ}$ ano, turma "E", envolvendo o uso de uma maquete para auxiliar na representação do relevo através das curvas de nível, (a) e (b) 180 


\section{LISTA DE ILUSTRAÇÕES (continuação)}

FIGURA 19 - Da fotografia aérea ao mapa do relevo passando por maquetes (a), (b) e (c). Aluno observando a maquete sob vários pontos de vista (d). Trabalho

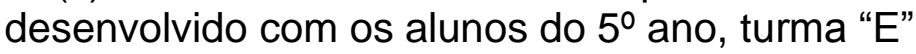
.184

FIGURA 20 - Alunos do $5^{\circ}$ ano, turma "A" da Escola Estadual Brigadeiro Tobias confeccionando a sua Linha do Tempo. 212

FIGURA 21 - Linha do Tempo construída por uma aluna do $5^{\circ}$ ano, turma "A".....213

FIGURA 22 - Alunos do 5 ano, turma "A", reproduzindo uma paisagem do centro histórico da cidade de Sorocaba-SP, através de um desenho a mão livre, sob orientação da professora Maria Cristina, (a), (b) e (c)

FIGURA 23. Avaliação em dupla da prancha temática: Linha do Tempo. Alunos do 5 ano, turma "A", (a) e (b). 216 


\section{LISTA DE GRÁFICOS}

GRÁFICO 1 - Percentual dos alunos da turma do $2^{\circ}$ ano $A$, segundo o número de questões certas. Prancha temática: Localização.

GRÁFICO 2 - Percentual dos alunos da turma do $2^{\circ}$ ano $\mathrm{B}$, segundo o número de questões certas. Prancha Temática: Localização

GRÁFICO 3 - Percentual dos alunos da turma do $2^{\circ}$ ano $D$, segundo o número de questões certas. Prancha temática: Localização

GRÁFICO 4 - Percentual dos alunos de todas as turmas dos $2^{\circ}$ anos, segundo o número de questões certas. Prancha temática: Localização.

GRÁFICO 5 - Percentual dos alunos da turma do $3^{\circ}$ ano B, segundo o número de questões certas. Prancha temática: Localização na sala de aula.

GRÁFICO 6 - Percentual dos alunos da turma do $3^{\circ}$ ano $C$, segundo o número de questões certas. Prancha temática: Localização na sala de aula. 162

GRÁFICO 7 - Percentual dos alunos de todas as turmas dos $3^{\circ}$ anos, segundo o número de questões certas. Prancha temática: Localização na sala de aula. 163

GRÁFICO 8 - Percentual dos alunos da turma do $5^{\circ}$ ano C, segundo o número de questões certas. Prancha temática - Sorocaba: Relevo. 186

GRÁFICO 9 - Percentual dos alunos da turma do 5ำ ano E, segundo o número de questões certas. Prancha temática - Sorocaba: Relevo.

GRÁFICO 10 - Percentual dos alunos de todas as turmas dos $5^{\circ}$ anos, segundo 0 número de questões certas. Prancha temática - Sorocaba: Relevo 187

GRÁFICO 11 - Percentual dos alunos da turma do 5o ano E, segundo o número de questões certas sobre o gráfico da pluviometria de Sorocaba. Prancha Temática Sorocaba: Clima - 2011.

GRÁFICO 12 - Percentual dos alunos da turma do $5^{\circ}$ ano $\mathrm{E}$, segundo o número de questões certas sobre o gráfico da temperatura de Sorocaba. Prancha temática Sorocaba: Clima - 2011. 192

GRÁFICO 13 - Percentual dos alunos da turma do $5^{\circ}$ ano E, segundo o número de questões certas. Prancha temática - Sorocaba: Clima. 


\section{LISTA DE GRÁFICOS (continuação)}

GRÁFICO 14 - Percentual dos alunos da turma do $5^{\circ}$ ano $\mathrm{E}$, segundo o número de questões certas sobre o texto da Prancha temática: Área urbana e área rural.

GRÁFICO 15 - Percentual dos alunos da turma do $5^{\circ}$ ano $\mathrm{E}$, segundo o número de questões certas. Prancha temática - Sorocaba: área urbana e área rural. 198

GRÁFICO 16 - Percentual dos alunos da turma do $5^{\circ}$ ano E, segundo o número de questões certas. Prancha temática - Sorocaba: População total, urbana e rural 2010 201

GRÁFICO 17 - Percentual dos alunos da turma do $5^{\circ}$ ano $\mathrm{E}$, segundo o número de questões certas sobre o texto da Prancha temática: Uso da terra e cobertura do solo de Sorocaba 206

GRÁFICO 18 - Percentual dos alunos da turma do 5ํaㅅ ano $\mathrm{E}$, segundo o número de questões certas. Prancha temática - Sorocaba: Uso da terra e cobertura do solo 2011 207

GRÁFICO 19 - Percentual da razão entre o número de acertos e o total de questões sobre a linha do tempo, segundo os períodos da história de Sorocaba, dos alunos das turmas dos 5a anos (A, B e C). Prancha temática: Linha do tempo

GRÁFICO 20 - Percentual da razão entre o número de acertos e o total de questões sobre a linha do tempo, segundo os eventos históricos brasileiros, dos alunos das turmas dos $5^{\circ}$ anos $(A, \quad B \quad e \quad C)$. Prancha temática: Linha do Tempo... 219

GRÁFICO 21 - Percentual da razão entre o número de acertos e o total de questões sobre a linha do tempo, segundo os eventos históricos mundiais, dos alunos das turmas dos $5^{\circ}$ anos (A, B e C). Prancha temática: Linha do Tempo. 


\section{LISTA DE QUADROS}

QUADRO 1 - Coordenadas Geográficas do Município de Sorocaba.

QUADRO 2 - Pranchas Temáticas do Protótipo selecionadas pelas professoras da Escola Estadual Baltazar Fernandes - 2ํㅜㄴ $3^{\circ}, 4^{\circ}$ e $5^{\circ}$ anos 130

QUADRO 3 - Modelo da proposta metodológica para avaliação parcial do Capítulo 1 - ingressando no atlas - prancha temática: localização - $2^{\circ}$ ano. .136

QUADRO 4 - Modelo da proposta das atividades para avaliação parcial do Capítulo 1 - Ingressando no Atlas. Prancha Temática: Localização - 2ํano. Etapa I. 137

QUADRO 5 - Modelo da proposta das atividades para avaliação parcial do Capítulo 1 - Ingressando no Atlas. Prancha Temática: Localização - 2ํano. Etapa II. 138

QUADRO 6 - Modelo da proposta das atividades para avaliação parcial do Capítulo 1 - Ingressando no Atlas. Prancha Temática: Localização - $2^{\circ}$ ano. Etapa III 139

QUADRO 7 - Exemplo da Avaliação realizada. Capítulo 1 - Ingressando no Atlas. Prancha Temática: Localização. $2^{\circ}$ ano, turma A. 146

QUADRO 8 - Modelo da proposta metodológica para avaliação parcial do Capítulo 1 - Ingressando no atlas - prancha temática: Localização na sala de aula - $3^{\circ}$ ano, turmas: B e C 151

QUADRO 9 - Modelo da proposta das atividades para avaliação parcial do Capítulo 1 - Ingressando no Atlas. Prancha Temática: Localização na sala de aula - 3o ano. Etapa I. 152 


\section{LISTA DE QUADROS (continuação)}

QUADRO 10 - Modelo da proposta das atividades para avaliação parcial do Capítulo 1 - Ingressando no Atlas. Prancha Temática: Localização na sala de aula - 3o ano. Etapa II 153

QUADRO 11 - Modelo da proposta das atividades para avaliação parcial do Capítulo 1 - Ingressando no Atlas. Prancha Temática: Localização na sala de aula - 3o ano. Etapa III - Primeira Parte. 154

QUADRO 12 - Modelo da proposta das atividades para avaliação parcial do Capítulo 1 - Ingressando no Atlas. Prancha Temática: Localização na sala de aula - $3^{\circ}$ ano. Etapa III - Segunda Parte. 155

QUADRO 13 - Exemplo da atividade realizada. Capítulo 1 - Ingressando no Atlas. Prancha Temática - Localização na sala de aula. Exercício - "coleta de dados da sala de aula". $3^{\circ}$ ano, turma "C" 156

QUADRO 14 - Exemplo da Avaliação realizada. Capítulo 1 - Ingressando no Atlas. Prancha Temática: Localização na sala de aula. $3^{\circ}$ ano, turma "C" 160

QUADRO 15 - Proposta metodológica para avaliação parcial do Capítulo 5 Sorocaba: Geografia. Prancha temática: relevo - 5o ano 167

QUADRO 16 - Proposta das atividades para avaliação parcial do Capítulo 5 Sorocaba: Geografia. Prancha temática: relevo - 5o ano. I Etapa - Primeira parte. 168

QUADRO 17 - Proposta das atividades para avaliação parcial do Capítulo 5 Sorocaba: Geografia - Prancha temática: Relevo. 5o ano. Etapa I - Segunda parte 169 
QUADRO 18 - Proposta das atividades para avaliação parcial do Capítulo 5 Sorocaba: Geografia - Prancha Temática: Relevo. 5a ano. Etapa II - Primeira parte.

QUADRO 19 - Proposta das atividades para avaliação parcial do capítulo 5 Sorocaba: Geografia - Prancha Temática: Relevo. 5o ano. Etapa II - Segunda parte. 171

QUADRO 20 - Proposta das atividades para avaliação parcial do Capítulo 5 Sorocaba: Geografia - Prancha Temática: relevo. 5o ano. Etapa III - Primeira parte. 172

QUADRO 21 - Proposta das atividades para avaliação parcial do Capítulo 5 Sorocaba: Geografia - Prancha Temática: Relevo. 5ํaㅇ. Etapa III - Segunda parte 173

QUADRO 22 - Exemplo das atividades de iniciação cartográfica: Orientação, como subsídio para a avaliação parcial do Capítulo 5. Prancha Temática: Relevo. 5a ano, turma "E". Etapa I - Primeira Parte. 175

QUADRO 23 - Exemplo das atividades de iniciação cartográfica: Orientação, como subsídio para a avaliação parcial do Capítulo 5. Prancha Temática: Relevo. 5aㅡ ano, turma "E". Etapa I - Segunda parte 176

QUADRO 24 - Exemplo das atividades de iniciação cartográfica: Orientação, como subsídio para a avaliação parcial do Capítulo 5. Prancha Temática: Relevo. 5a ano, turma "E". Etapa I - Terceira parte 177

QUADRO 25 - Exemplo das atividades realizadas pelos alunos para subsidiá-los na avaliação parcial do Capítulo 5 - Sorocaba: Geografia. Prancha Temática: Relevo. 5o ano E. Etapa II. 178 


\section{LISTA DE QUADROS (continuação)}

QUADRO 26 - Exemplo das atividades realizadas pelos alunos para subsidiá-los na avaliação parcial do Capítulo 5 - Sorocaba: Geografia. Prancha Temática: Relevo. 5ำ ano E. Etapa II 179

QUADRO 27 - Exemplo das atividades realizadas pelos alunos para subsidiá-los na avaliação parcial do Capítulo 5 - Sorocaba: Geografia. Prancha Temática: Relevo. $5^{\circ}$ ano E. Etapa II 181

QUADRO 28 - Exemplo das atividades realizadas pelos alunos para subsidiá-los na avaliação parcial do Capítulo 5 - Sorocaba: Geografia. Prancha Temática: Relevo. 5o ano E. Etapa II. 182

QUADRO 29 - Exemplo da Avaliação realizada. Capítulo 5 - Sorocaba: Geografia. Prancha Temática: Relevo. $5^{\circ}$ ano, turma "E". 185

QUADRO 30 - Proposta metodológica para avaliação parcial do Capítulo 5 Sorocaba: geografia - Prancha Temática - Sorocaba: clima. 5o ano 188

QUADRO 31 - Exemplo das atividades realizadas pelos alunos para subsidiá-los na avaliação parcial do Capítulo 5 - Sorocaba: Geografia. Prancha Temática Sorocaba: Clima. 5ํㅡ. ano. Etapa I. 189

QUADRO 32 - Exemplo das atividades realizadas pelos alunos para subsidiá-los na avaliação parcial do Capítulo 5 - Sorocaba. Prancha Temática - Sorocaba: Clima. 5ำ ano. Etapa II 190

QUADRO 33 - Exemplo da Avaliação realizada. Capítulo 5 - Sorocaba: Geografia. Prancha Temática - Sorocaba: Clima. $5^{\circ}$ ano, turma "E”. Etapa III. 191 


\section{LISTA DE QUADROS (continuação)}

QUADRO 34 - Proposta metodológica para avaliação parcial do Capítulo 5 Sorocaba: Geografia. Prancha Temática - Sorocaba: área urbana e área rural, 5oㅡ ano

QUADRO 35 - Exemplo da atividade realizada. Capítulo 5 - Sorocaba: Geografia. Prancha Temática - Sorocaba: Área Urbana e Área Rural. $5^{\circ}$ ano, turma "E". Etapa I. 195

QUADRO 36 - Exemplo da atividade realizada. Capítulo 5 - Sorocaba: Geografia. Prancha Temática - Sorocaba: Área Urbana e Área Rural. 5ำ ano, turma "E". Etapa II. 196

QUADRO 37 - Proposta metodológica para avaliação parcial do Capítulo 5 Sorocaba: Geografia. Prancha Temática - Sorocaba: População total, urbana e rural. 5ำ ano

QUADRO 38 - Exemplo da Avaliação realizada. Capítulo 5 - Sorocaba: Geografia. Prancha Temática - Sorocaba: População total, urbana e rural. 5o ano, turma "E". 200

QUADRO 39 - Proposta metodológica para avaliação parcial do Capítulo 5 Sorocaba: Geografia. Prancha Temática: uso da terra e cobertura do solo. 5ํano, turma "E". 202

QUADRO 40 - Exemplo da atividade realizada pelos alunos para subsidiá-los na avaliação parcial do Capítulo 5 - Sorocaba: Geografia. Prancha Temática Sorocaba: uso da terra e cobertura do solo. $5^{\circ}$ ano, turma "E". Etapa I 203

QUADRO 41 - Exemplo da atividade realizada pelos alunos para subsidiá-los na avaliação parcial do Capítulo 5 - Sorocaba: Geografia. Prancha Temática Sorocaba: uso da terra e cobertura do solo. $5^{\circ}$ ano, turma "E". Etapa II. 204 


\section{LISTA DE QUADROS (continuação)}

QUADRO 42 - Exemplo da Avaliação realizada. Capítulo 5 - Sorocaba: Geografia. Prancha Temática - Sorocaba: uso da terra e cobertura do solo. 5o ano, turma "E" 205

QUADRO 43 - Modelo da proposta metodológica para avaliação parcial do Capítulo 3 - Sorocaba: sua história. Prancha temática - Linha do tempo - 5aㅡo 210

QUADRO 44 - Proposta da atividade para avaliação parcial do capítulo III Sorocaba: sua história. Prancha Temática - Linha do tempo - 5o ano. Etapa I.......211

QUADRO 45 - Proposta da atividade para avaliação parcial do capítulo 3 Sorocaba: sua história. Prancha Temática - Linha do Tempo - 5o ano. Etapa II.....211

QUADRO 46 - Exemplo da avaliação realizada. Capítulo 3 - Sorocaba: sua história. Prancha Temática: Linha do Tempo, $5^{\circ}$ ano, turma "C". 


\section{LISTA DE ABREVIATURAS E SIGLAS}

ACl Associação Cartográfica Internacional

AGB Associação dos Geógrafos Brasileiros

AGCT Área de Geoprocessamento e Cadastro Técnico

CD-ROM Compact Disk Read Only Memory

CNPq Conselho Nacional de Desenvolvimento Científico e Tecnológico

EUA Estados Unidos da América -

FFLCH Faculdade de Filosofia, Letras e Ciências Humanas

HTPC Horas de Trabalho Coletivo Pedagógico

IBGE Instituto Brasileiro de Geografia e Estatística

ICA International Cartographic Association

IHGG Instituto Histórico Geográfico e Genealógico de Sorocaba-

LDB Lei de Diretrizes e Bases da Educação

MEC Ministério Educação e Cultura

PCN Parâmetros Curriculares Nacionais

SARESP Sistema de Avaliação de Rendimento Escolar do Estado de São Paulo

SEHAB Secretaria de Habitação e Urbanismo

SIG Sistema de Informações Geográficas

UGI União Geográfica Internacional

USP Universidade de São Paulo 


\section{SUMÁRIO}

INTRODUÇÃO .26

CAPÍTULO I - A OPÇÃO METODOLÓGICA

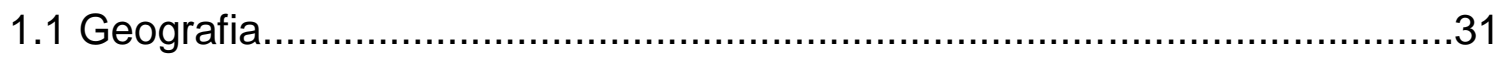

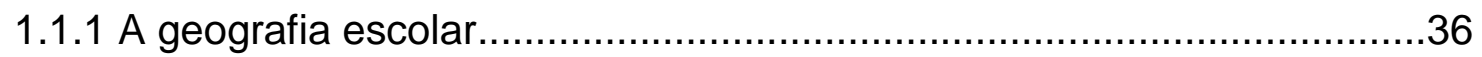

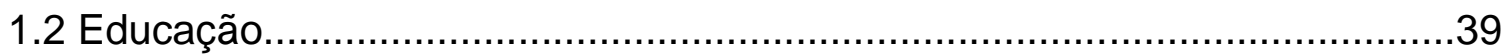

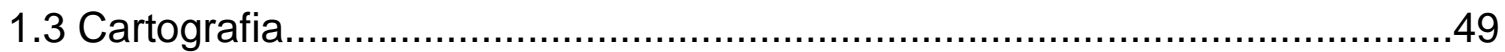

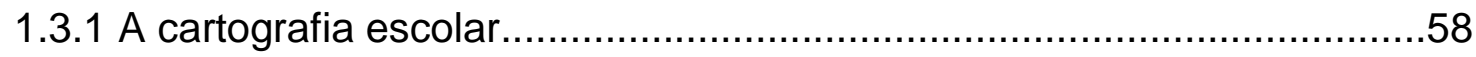

\section{CAPÍTULO II - OS ATLAS EM GERAL E OS ATLAS ESCOLARES...62}

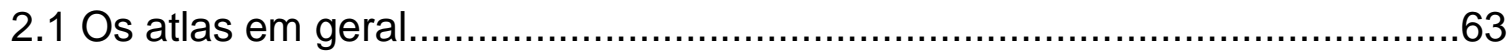

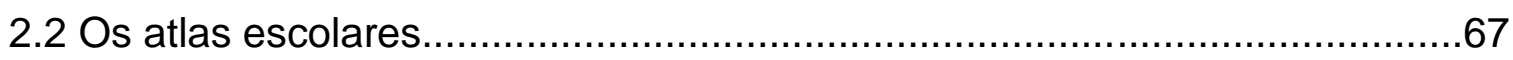

2.3 Os atlas escolares para o conhecimento do lugar..................................71

\section{CAPÍTULO III - PROPOSTA METODOLÓGICA PARA A ELABORAÇÃO DE ATLAS GEOGRÁFICOS ESCOLARES.}

3.1 As dimensões espaço e tempo da realidade ..........................................77

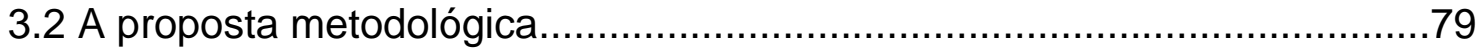

3.2.1 O ensino DO mapa.................................................................... 79

3.2.1.1 A construção e representação do ESPAÇO na criança..................79

3.2.1.2 A representação da realidade espacial pela criança.....................83

3.2.1.3 A construção e representação do TEMPO na criança.....................96

3.2.1.4 A representação da realidade no tempo pela criança.....................98

3.2.2 O ensino PELO mapa..................................................................100

3.2.3 Organização dos atlas geográficos escolares.................................108

3.2.3.1 O recorte espacial..........................................................108

3.2.3.2 O recorte temático........................................................110 


\section{CAPÍTULO IV - IMPLEMENTAC̄̃̃O DE UM PROTÓTIPO DE ATLAS}

PARA O MUNICÍPIO DE SOROCABA - SP............116

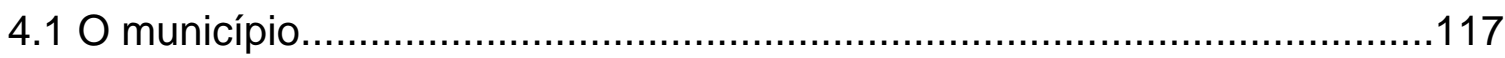

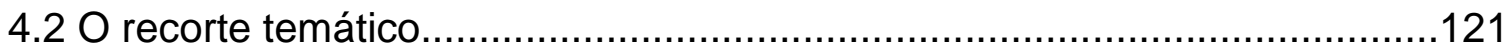

4.3 A diagramação das pranchas temáticas...............................................125

CAPÍTULO V - O PROTÓTIPO NA SALA DE AULA..........................126

5.1 As escolas participantes do processo de avaliação.......................................128

5.1.1 Escola Estadual Baltazar Fernandes............................................128

5.1.2 Escola Estadual Brigadeiro Tobias..................................................131

5.2 Metodologia seguida para avaliação parcial dos capítulos do protótipo.....133

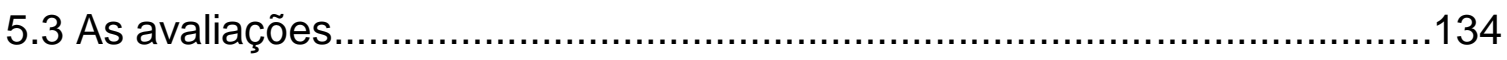

5.3.1 As avaliações na Escola Estadual Baltazar Fernandes.......................134

5.3.1.1 Capítulo 1 - Ingressando no Atlas......................................134

5.3.1.1.1 Apreensão e representação do espaço: Localização.....136

5.3.1.1.2 Apreensão e representação do espaço - Coordenadas Geográficas: Localização na sala de aula.....................150

5.3.1.2 Capítulo 5 - Sorocaba: geografia........................................164

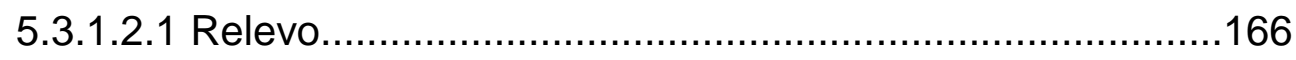

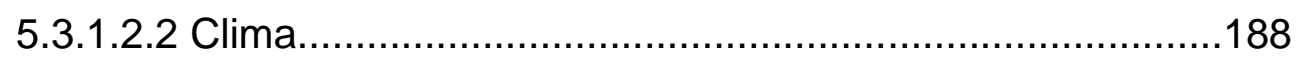

5.3.1.2.3 Área Urbana e área rural.............................................194

5.3.1.2.4 População total, urbana e rural.....................................199

5.3.1.2.5 Uso da terra e cobertura do solo...................................202

5.3.2 As avaliações na Escola Estadual Brigadeiro Tobias...........................208

5.3.2.1 Capítulo 3 - Sorocaba: sua história.....................................208

5.3.2.1.1 Linha do tempo........................................................210

CONSIDERAÇÕES FINAIS............................................................221

REFERÊNCIAS .............................................................................229

APÊNDICE - ATLAS ESCOLAR DE SOROCABA - SP : História, Geografia e Ambiente. Anos Iniciais do Ensino Fundamental....................248 


\section{INTRODUÇÃO}

No período correspondente à última década do século $X X$ até 0 momento atual, observa-se que a Educação Básica no Brasil e, mais especificamente, o Ensino Fundamental, experimentou alguns avanços, como a aprovação da nova LBD, a definição de parâmetros curriculares de abrangência nacional (PCNs), e o conjunto de ações previstas no Plano Nacional de Educação (PNE) e no Plano Desenvolvimento da Educação (PDE), visando a melhoria da qualidade da Educação nos seus diferentes níveis. No entanto, apesar destes avanços, as políticas educacionais no Brasil ainda se caracterizam pela descontinuidade e centralização.

Paralelamente às ações governamentais, também é objeto de preocupação a qualidade da formação dos professores, bem como a sua preparação para ensinar o conteúdo previsto no currículo e, não menos importante, a verificação da aprendizagem dos alunos formados.

Neste contexto, os Atlas Escolares surgem como recursos didáticos de apoio, que aliados às práticas de alfabetização cartográfica e aos exercícios em sala, permitem viabilizar o ensino/aprendizagem do conteúdo previsto de Geografia para cada ano do Ensino Fundamental.

Ao propor uma metodologia para a elaboração de Atlas Escolares para o conhecimento local, aplicando-a a um município do Estado de São Paulo, esta Tese retoma a questão de se produzir recursos didáticos e sugerir práticas de ensino que sejam adequadas tanto para professor quanto para o aluno. 


\section{Objetivos}

- Propor uma metodologia para a elaboração de Atlas Escolares para o conhecimento local.

- Aplicar a metodologia proposta, mediante a implementação de um protótipo de Atlas Escolares para o município de Sorocaba-SP.

- Avaliar a adequação do Protótipo em sala de aula.

\section{Estrutura do trabalho}

O trabalho está estruturado em cinco capítulos e um apêndice. No primeiro capítulo, trata-se da opção metodológica. A seguir, no capítulo 2, abordam-se os Atlas em geral e os Atlas Escolares. A proposta metodológica para a elaboração de Atlas Geográficos Escolares é apresentada no capítulo 3. No quarto capítulo, aborda-se a implementação de um protótipo de Atlas para o município de SorocabaSP. O capítulo 5 relata, detalhadamente, como o protótipo do Atlas foi utilizado e avaliado em sala de aula. Nas considerações finais, o trabalho é completado com a identificação das suas principais contribuições. No apêndice, apresenta-se o protótipo do Atlas Escolar para o município de Sorocaba-SP.

Ainda dentro deste contexto, tem-se a dizer que o tema deste estudo também é fruto de um processo que começou com a dissertação de Mestrado, "Na busca de uma metodologia da cartografia temática para o trabalho com mapas em geografia", defendida em 2001, na Faculdade de Filosofia, Letras e Ciências Humanas Departamento de Geografia. A pesquisa citada, em termos gerais, tratou:

. A cartografia e a sua dimensão social.

. Geografia e cartografia.

. A cartografia temática e o trabalho com mapas.

A pretensão da pesquisa citada era buscar uma metodologia adequada para o trabalho com mapas no ensino superior junto a alunos de graduação, futuros 
professores, de forma que estes tenham um apoio teórico-metodológico dos mapas temáticos junto ao ensino/aprendizagem da geografia ao nível de Ensino Fundamental e Médio. Para tanto, foram selecionados onze temas considerando-se a realidade natureza e sociedade do Estado de Goiás. Para cada tema foi apresentado uma discussão em termos conceituais, uma proposta de atividade e, por fim, um modelo resolvido da atividade desenvolvida.

$\mathrm{Na}$ ocasião, a banca examinadora sugeriu a título de pesquisas futuras um estudo voltado para a metodologia de atlas.

Além disso, é importante ressaltar que o tema dessa Tese advém de uma experiência profissional com alunos de graduação em Geografia, que normalmente demonstram certa dificuldade no aprendizado da disciplina de cartografia e na experiência de sala de aula na rede pública Federal de Goiânia-Go e São Paulo-SP na Educação Básica Municipal e Estadual. 
CAPÍTULO I

A OPÇÃO METODOLÓGICA 


\section{CAPÍTULO I - A OPÇÃO METODOLÓGICA}

Para bem fundamentar a proposta desta pesquisa apresentada como Tese de Doutorado, considerar-se-á essencial transitar pelas questões metodológicas que regem três áreas científicas: Cartografia, Educação e Geografia. Estas compõem a Cartografia Escolar, como área de ensino e pesquisa em construção no atual contexto social e cultural, que por sua vez irá lastrear o encaminhamento metodológico para Atlas Geográficos Escolares [Fig.1]

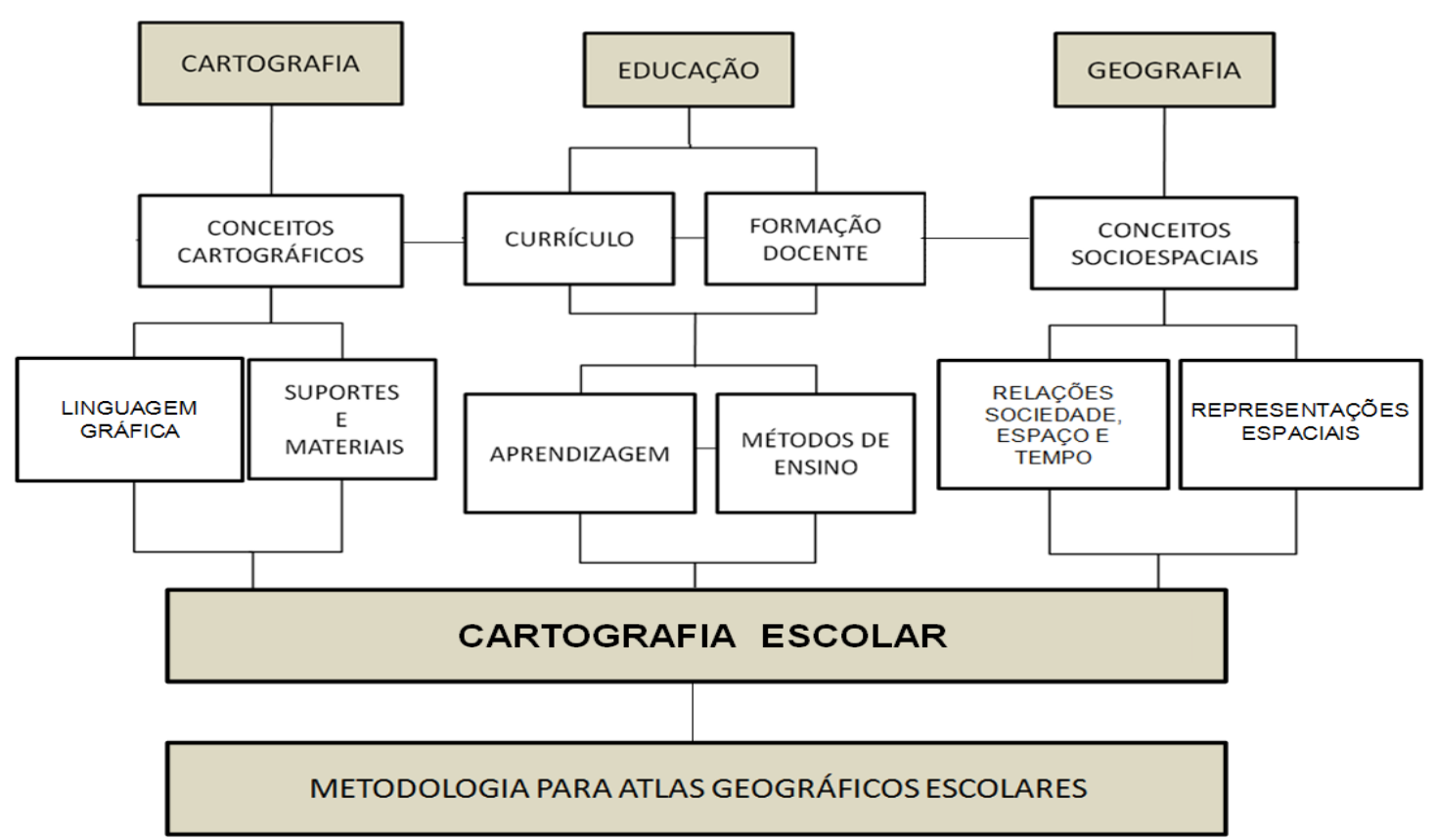

Figura 1 - Organograma da interação entre a Cartografia, a Educação e a Geografia que compõem a Cartografia Escolar que fundamentará a proposta em pauta. Fonte: ALMEIDA (2001, p. 22; 2007, p. 10). Com adaptações.

O organograma acima apresenta a articulação que deve haver entre a cartografia, que está atrelada às discussões em torno dos conceitos cartográficos, linguagem da representação gráfica, suportes e materiais. A Educação que contempla o currículo e a formação docente por um lado e, por outro, a aprendizagem e os métodos de ensino. Geografia, que por sua vez, participa com seus conceitos sócio espaciais, envolvendo discussões em torno das relações entre a sociedade, espaço e tempo e suas representações em mapas. 
Quando se deseja trabalhar com metodologia de atlas geográfico escolar, essas três áreas científicas, segundo ALMEIDA $(2001$; 2007) são fundamentais. Em especial, em termos de cartografia, destacamos a Linguagem da Representação Gráfica, pois os estudos de Bertin, Bonin, Bord, Blin e Gimeno, além de outros, pautados na Semiologia Gráfica e no tratamento gráfico da informação, demonstram que a "[...] aquisição de conhecimentos passa pela observação e pela organização lógica do pensamento." (LE SANN, 2010, p. 95). Sendo assim, a Semiologia Gráfica, a linguagem da representação gráfica e o tratamento gráfico da informação "[...] são instrumentos privilegiados para o ensino, em geral, e para o ensino de Geografia, em particular." (LE SANN, 2010, p. 96). E o uso desse entendimento para o estudo de uma metodologia de atlas geográficos escolares mostra-se aceitável.

\subsection{Geografia}

Ao enveredar por caminhos que se dirigem às bases de uma metodologia de atlas geográficos escolares para promover o ensino e aprendizagem de seus mapas e da Geografia por seus mapas, que representam temas da realidade social em composição com a natureza, é imperativo tecer considerações sobre a ciência dessa conjunção.

Sabe-se que o surgimento do saber geográfico é muito antigo, pois no homem sempre existiu a necessidade de conhecer o seu lugar, seu entorno, bem como outros ambientes próximos ou distantes. Esta ansiedade de colher informações sempre fez parte da humanidade, seja por uma questão de sobrevivência, conhecimento ou dominação. Assim, de observação em observação, os dados da Terra foram aos poucos sendo adquiridos, trabalhados e registrados, dentre outras formas, também através de desenhos que compunham esboços representativos de uma dada realidade. Um saber que se confundiu com o de fazer mapas (PEREIRA, 1993, p. 36). 
Entretanto, a sistematização do conhecimento geográfico somente ocorreu no início do século XIX, momento em que a Europa começou a processar o avanço e domínio das relações capitalistas de produção. Neste contexto, foram Alexandre von Humboldt e Karl Ritter, que sistematizaram as primeiras bases teóricas e propostas metodológicas que deram origem à geografia.

Na França, Paul Vidal de La Blache, por volta da década de 1870 estabeleceu uma geografia voltada para questões mais humanas, fincando os alicerces para uma Geografia regional.

Já no século XX, os Estados Unidos concorreram com os europeus, em termos de produção do pensamento geográfico, principalmente a partir dos anos trinta com Hartshorne e outros estudiosos.

Um marco que não pode deixar de ser mencionado teve lugar na metade da década de 1950, tendo-se desenvolvido logo a seguir. Na época emergiu um movimento de renovação do pensamento geográfico, colocando em questão a tradicional postura sobre o objeto, o método e o próprio significado de geografia.

Compareceu, assim, uma nova geografia, que se formulou em duas vertentes: a Geografia pragmática e a Geografia crítica, ambas vistas como decorrentes de posicionamentos sociais e/ou de engajamentos políticos.

Consoante com os novos encaminhamentos do saber geográfico o modelo tradicional do currículo escolar de geografia de todos os níveis, também teve suas reformulações e críticas.

Com particular atenção ao vínculo dos mapas com a geografia, deve-se citar o trabalho de Lacoste (1976), “La géographie: ça sert d'abord, à faire la guerre”. Nele, o autor destacou a existência de duas geografias: a das Forças Armadas, em sua essência uma cartografia por excelência, e a dos Professores. Ressaltou ainda a grande importância que é dada aos mapas para o exército, no sentido de servirem de verdadeiros mecanismos de conhecimento, planejamento e de dominação sobre o espaço e as pessoas que nele habitam. Em contrapartida, para os professores e para a sociedade no geral, eles não passariam de meras figuras ilustrativas, sem 
serventia alguma, além de se apresentarem como difíceis de serem entendidos e confeccionados. Eram os mapas para os especialistas da área.

Como referência teórica e metodológica de peso do século $X X$, merece destaque as obras de Milton Santos, que apresentaram uma concepção de geografia mais global. Em seu livro "Por uma Geografia Nova", na primeira edição de 1978, o Professor abordou de forma crítica a geografia que fora vista como tradicional, a crise do pensamento geográfico e as principais propostas de renovação concretizadas pela geografia pragmática, finalizando com a exposição da concepção do objeto geográfico. Para o autor, é preciso não apenas discutir o espaço social, mas também conceber a produção do espaço como objeto. Definiu o espaço como acumulação de trabalho, incorporação de capital na superfície terrestre, criando formas duráveis, as quais ele chamou de "rugosidades", que gerariam imposições sobre a ação presente da sociedade, pois elas persistem mais do que o processo que as criou.

Em publicações mais recentes, da década de 1990, identificou o espaço do presente momento histórico como um meio técnico científico-informacional, o próprio meio geográfico, caracterizado por incluir multinacionais, globalização da produção e do produto, onde

[...] tudo começa com o conhecimento do lugar, tarefa conjunta que é hoje tanto mais possível porque cada lugar é o mundo. É daí que advém uma possibilidade de ação. Conhecendo os mecanismos do mundo, percebemos por que as intencionalidades estranhas vêm instalar-se em um dado lugar, e nos armamos para sugerir o que fazer no interesse social. (SANTOS ,1994, p. 116-7).

Em outro trabalho, colocou ainda que:

Fora dos lugares, produtos, inovações, populações, dinheiro, por mais concretos que pareçam são abstrações. A definição conjunta e individual de cada qual depende de uma dada localização. Por isso a formação sócioespacial e não o modo de produção constitui o instrumento adequado para entender a história e o presente de um país. Cada atividade é uma manifestação do fenômeno social total. E o seu efetivo valor somente é dado pelo LUGAR em que se manifesta, juntamente com outras atividades .(SANTOS, 1996, p.107). 
Em seus escritos, enfatizava também que só é possível compreender o conceito de lugar, se for pensado como "o espaço do acontecer solidário". Assim,

No lugar, se sobrepõe, dialeticamente, o eixo das sucessões, que transmite os tempos externos das escalas superiores e o eixo dos tempos internos, que é o eixo das coexistências, onde tudo se funde, entrelaçando, definitivamente, as noções e as realidades de espaço e tempo. (SANTOS, 1996, p. 258).

O lugar pode ter duas qualificações: os espaços opacos que não se mobilizaram de forma significativa para o processo de modernização e os espaços seletivos que estão aptos para o mundo competitivo, onde a fluidez é a palavra de ordem das forças hegemônicas. Neste contexto, entende-se que os novos usos do território, caracterizam-se pela simbiose entre a ciência, a técnica e a informação.

O autor enfatiza a discussão em torno do conceito do lugar, o qual deve estar arraigado em conceitos, como: formação socioespacial, meio técnico científicoinformacional, horizontalidades, verticalidades, densidades técnicas e densidades comunicacionais, coexistência etc. O conceito de formação socioespacial, em especial,

[...] possibilita o conhecimento da territorialidade e da identidade da região, mostra ainda a importância das relações entre o modo de produção e sua espacialidade, as particularidades dos lugares. Não existe formação econômica e social descolada do espaço, pois ambas são categorias interdependentes, onde as transformações são processadas no espaço através do trabalho. (SANTOS, 2005, p. 27).

Dentro deste contexto, o espaço banal tem como característica as suas peculiaridades do lugar, seja na dimensão cultural da população que nele habita, seja na vocação da exploração de seus recursos naturais. Estas manifestações podem ser abafadas, parcial e/ou totalmente, na medida em que este espaço se torna seletivo ao se conformar plenamente às exigências da modernidade e se estruturando de acordo com as mesmas. Sendo assim, o território usado constitui-se no espaço banal, entendido como um sistema de objetos indissociável de um sistema de ações cuja totalidade é o mundo. 
Assim, o mundo se revela, conforme Santos (2000) como um todo sistêmico em função da unicidade da técnica, da ciência e da informação que permitem a convergência dos momentos e a cognoscibilidade do planeta. É também desigual e combinado, pois o uso das técnicas, da ciência e da informação é diferenciado. $O$ mundo, portanto, não é formado por pedaços fragmentados e desconectados. Ao contrário, apresenta-se enquanto possibilidade, seja por inteiro em todas as partes, seja para todas as pessoas. E é a busca da visão de mundo que permite a coerência entre as idéias e o método de pesquisa.

Em termos de Brasil, a sua formação socioespacial mostra "fragmentação" e "articulação". Tal fato se deve a uma "aceleração desigual dos tempos nos seus subespaços, tomados como manifestações existentes por meio da (re)funcionalização do processo de globalização". A relação lugar-mundo apresenta ações que constituem arranjos contínuos e/ou descontínuos pelas horizontalidades e verticalidades ${ }^{1}$. Além disso, nota-se que a utilização dos lugares pelas empresas depende de dois dados: normas e formas, como um conjunto indissociável.

Toda essa produção científica, que vai da geografia tradicional até a crítica, passou por diferentes momentos, gerando inúmeras reflexões acerca dos objetos e métodos da citada ciência.

Junto a este contexto de uma geografia mais crítica, a cartografia atual além de ter que se afirmar cada vez mais com status de ciência, o que já vinha sendo feito desde o início do século XX, terá que buscar novas concepções voltadas para novas metodologias. Autores como Rimbert (1990), Taylor (1994), MacEachren (1994), Artimo (1994), Peterson (2005), e outros, em seus trabalhos, chamaram a atenção, em especial, dos estudiosos da área, para uma nova cartografia, abrindo espaço para uma nova concepção metodológica para os Atlas escolares, através da visualização, a visualização científica, que junto à cartografia ganhou o nome de Visualização cartográfica, possibilitando grandes chances para as novas relações entre a moderna geografia (a geografia crítica) e a atual cartografia.

\footnotetext{
O termo horizontalidade deve ser entendido como solidariedade orgânica, característica das ações regionais e, contraditoriamente, solidariedade organizacional, caracterizada pela racionalidade imposta que nasce distinta, determinando normas e formas.
} 
Esta cartografia abriria as portas para as elaborações dos atlas digitais e eletrônicos, com consistentes acréscimos no domínio do ensino.

A esse respeito, a Geografia contribuirá com concepções que abarcam diversos fenômenos, sejam físicos (da natureza), sejam humanos (da sociedade), utilizando representações espaciais em suas análises, pois o homem ao produzir o espaço em seu viver, modifica a natureza e produz a sua própria natureza mediada pelo trabalho. Assim, "[...] a sociedade está agindo sobre ela própria, e jamais sobre a materialidade exclusivamente." A dialética, pois, não se dá entre sociedade e paisagem, mas entre sociedade e espaço. E vice-versa". (SANTOS, 1996, p. 88).

\subsubsection{A Geografia Escolar}

Segundo Capel (1983) e Pereira (1999), a geografia escolar tem a sua origem na Alemanha do início do século XIX, cujo território estava dividido em diferentes reinos, tendo mais destaque o da Prússia. Para o estudo da geografia do território alemão, na época, dava-se destaque para cada região segundo o estado (reino) do qual ela fazia parte. Uma geografia escolar também teria surgido neste mesmo país. Era comum, também, o uso de mapas mudos.

Conteúdos descritivos e matemáticos como, a Terra e seus movimentos, pontos cardeais, sistemas de montanhas, cursos dos rios, cosmografia, geografia geral dos continentes, etc. faziam parte do currículo escolar alemão-prussiano

Também na França, por volta do início do século XIX, a geografia escolar teve sua aparição, tendo os seus fundamentos pautados nos ideais da Revolução. Assim, mesmo de forma tardia em relação à Alemanha, foi neste país, pelo menos considerando o universo da Europa, que houve um início mais incisivo na organização da instrução pública, incluindo a Geografia. 
Reformas na educação básica, na Alemanha e na França, a partir da década de 1870, resultaram em uma demanda favorável de professores. Assim,

[...] desde el final de la década de los 70 la presión para la institucionalización de la geografía en los centros de enseñanza superior era muy fuerte. La necesidad de formar los profesores que las reformas pedagógicas de los niveles primario y secundario exigían es, sin duda, el factor decisivo para la aparición y la afirmación de este proceso (CAPEL, 1983, p. 121).

Dentro deste contexto, a geografia escolar teve o seu valor para a sociedade, de forma não menos importante e necessária, que a própria institucionalização da geografia, enquanto ciência.

No Brasil, no século XIX, o Colégio Pedro II, no Rio de Janeiro, foi um marco referencial do ensino oficial de Geografia, quando, por meio dele se deu o início da produção de livros e a atlas de Geografia. (AGUIAR, 2011:41).

Um dos objetivos dessa instituição, já ingressando no século XX, era fomentar outras escolas públicas e mesmo as privadas. Entretanto, a geografia escolar nesta instituição e em suas seguidoras era de caráter descritivo, mnemônica, enumerativa e enciclopédica, isto é, apresentava-se distante da realidade social e abarcava um caráter de ser uma ciência que tinha por objetivo descrever a Terra. Segundo Issler (1973: 55-56), outras questões como: administração do ensino secundário, os inúmeros projetos, carência de recursos, a qualificação dos professores dentre outros devem ser levantadas em relação aos problemas no ensino da geografia no Império:

A situação do ensino da Geografia no Império ressentiu-se também dos inúmeros problemas que afetaram todo o processo de educação. Certamente de melhoras significativas nos programas estariam relacionadas com a longa série de fatos que tumultuaram a administração do ensino secundário. Os inúmeros projetos de reforma discutidos, aprovados ou não, e arquivados; as discussões de questões em torno da centralização e descentralização, os gabinetes de passagem, tudo isso e mais uma situação constrangedora de trabalho escolar: carência de recursos, ausência de professores qualificados e baixos salários, a ponto de escolas ficarem sem mestre por não haver interessados; a disseminação de aulas particulares de preparação para os exames, a improvisação, enfim, a falta de uma definição para a escola média. (ISSLER,1997 apud PESSOA, 2007, p. 41). 
Deve-se apontar, igualmente, que o início da Geografia escolar no Brasil teve o apoio dos livros didáticos nacionais editados no século XIX. Seus autores, professores desse ensino, para organizá-los valiam-se dos programas oficiais do citado Colégio Pedro II e da própria prática desses mestres. Eles construíram, assim, um conhecimento fora daquele sistematizado na academia, construído como um saber original elaborado dentro da escola para ser aplicado na própria escola, contando, com a facilidade de assimilação. Esta geografia escolar tinha como componentes básicos, conteúdos expositivos (as vulgatas), exercícios, práticas motivadoras e formas de avaliação (CHERVEL, 1990; BOLIGIAN e ALMEIDA, 2001).

$\mathrm{Na}$ organização destes livros escolares de geografia fazia parte também conteúdos de cartografia, congregando uma série de noções, conceitos e temas, tal como persistem até a atualidade.

No ensino de geografia para escolares dos primeiros anos do processo educacional, vários autores apontam possibilidades em prol da formação do cidadão, quando se coloca o aluno em posição crítica diante das desigualdades sociais que comparecem diante de sua vivência concreta, entrevendo, assim, uma realidade de múltiplas relações integrando o todo mundial (STRAFORINI, 2008, p. 79).

Na metade da década de 1950, a Geografia Escolar sofreu e ainda pode-se sentir nela, certa influência significativa da Geografia tradicional, distanciando-se de uma Geografia atual mais crítica. Essa forma de ensino junto à Geografia aparece nos estudos descritivos das paisagens naturais e humanizadas, muitas vezes de forma dissociada do espaço vivido pela sociedade e das relações contraditórias de produção e organização do espaço dentro de uma totalidade-mundo. Os envolvidos nesse contexto, os professores com seus procedimentos didático-pedagógicos intencionais, muitas vezes se dão por satisfeitos em promover, principalmente, a descrição e a memorização (associação mais repetição) dos elementos que compõem as paisagens. Contudo, não atentam em esperar que os próprios alunos estabeleçam relações, analogias ou generalizações e, muito menos como eles estariam representados nos mapas e como trabalhá-los para apreendê-los. 
Lembra-se, com base em Moraes (2008), que o trabalho com os mapas em sala de aula se restringe, ainda, aqui e ali, ao ato de fazer cópias, responder a questões, bem como outras atividades afins.

Entretanto, não se pode cercear que a produção e reformulação científica da Geografia e a proposição de seu Currículo nas últimas décadas da atualidade, trouxe algumas mudanças para o seu ensino. Categorias de estudo da Geografia como: território, paisagem e lugar passaram a ser vistos sob novos olhares, diante dos novos desafios da ciência geográfica atual. $O$ que se mostrou realmente decisivo para o ensino da geografia, em especial a partir da década de 1980, pelo fato de ter sido desenvolvida uma gama de propostas curriculares voltadas para 0 período da quinta a oitava séries ${ }^{2}$, foi de se considerar uma geografia mais coerente com a Geografia Crítica.

A Geografia para o escolar deve ser trabalhada não apenas sob o ponto de vista que a centraliza no espaço geográfico. Deve também considerar as citadas categorias, paisagem, território e lugar, adequadas às características cognitivas e afetivas dos escolares, colocando o homem, numa perspectiva histórica, como um ser social e cultural que deixa marcas de seus valores no processo de construção de seu espaço.

\subsection{Educação}

Antes de discorrer sobre um tema tão vasto como a "Educação", deve-se primeiramente delimitar o escopo para a análise. Assim, nesta seção, abordaremos questões relacionadas à Educação em território brasileiro, no nível de Educação

\footnotetext{
2 A Lei $\mathrm{n}^{\mathrm{o}}$ 11.274, de 6 de fevereiro de 2006, altera a Lei de Diretrizes e Bases (LDB 9.394/96) e amplia o Ensino Fundamental para nove anos de duração, com a matrícula de crianças de seis anos de idade e estabelece prazo de implantação, pelos sistemas, até 2010. A partir dessa lei o Ensino Fundamental passou a compreender os "Anos Iniciais" (do $1^{\circ}$ ano ao $5^{\circ}$ ano) e "Anos Finais" (do $6^{\circ}$ ano ao $9^{\circ}$ ano). Dentro deste contexto, os ciclos apontados pelos PCNs seguem a seguinte correspondência. $1^{\circ}$ ciclo $\left(1^{\mathrm{a}}\right.$ e $2^{\mathrm{a}}$ série $), 2^{\mathrm{o}}$ ciclo $\left(3^{\mathrm{a}}\right.$ e $4^{\mathrm{a}}$ série $), 3^{\mathrm{o}}$ ciclo $\left(5^{\mathrm{a}}\right.$ e $6^{\mathrm{a}}$ série) e $4^{\mathrm{o}}$ ciclo $\left(7^{\mathrm{a}}\right.$ e $8^{\mathrm{a}}$ série). A equivalência entre o Ensino Fundamental de nove e o de oito anos passa a ser: $1^{\circ}$ ano (pré-escola), $2^{\circ}$ ano ( $1^{\mathrm{a}}$ série), $3^{\mathrm{o}}$ ano $\left(2^{\mathrm{a}}\right.$ série), $4^{\mathrm{o}}$ ano ( $3^{\mathrm{a}}$ série), $5^{\mathrm{o}}$ ano $\left(4^{\mathrm{a}}\right.$ série $), 6^{\mathrm{o}}$ ano $\left(5^{\mathrm{a}}\right.$ série), $7^{\circ}$ ano ( $6^{\mathrm{a}}$ série $), 8^{\circ}$ ano ( $7^{\mathrm{a}}$ série $)$ e $9^{\circ}$ ano ( $8^{\mathrm{a}}$ série $)$.
} 
Básica, compreendendo apenas o Ensino Fundamental da disciplina Geografia, dentro de um período recente definido a partir de 1990 até os tempos atuais.

Segundo Dourado (2007), a Educação constitui-se num amplo processo de socialização da cultura, onde a Escola é o local de produção e apropriação do saber. Além disso, a Escola como instituição social possui uma organização própria, que deve ser orientada por políticas, formas de gestão e processos, visando os objetivos da formação dos indivíduos da sociedade (DOURADO, 2007).

Em se tratando da Educação Básica, esta compreende três etapas: a educação infantil, o ensino fundamental e o médio. De acordo com o artigo $4^{\circ}$. da LDB (lei no. 9394/96), "a educação básica é um direito do cidadão e um dever do Estado, que deve atendê-lo mediante oferta qualificada" e, portanto, é indispensável para que este indivíduo participe ativa e criticamente de grupos, em prol de uma sociedade mais democrática e justa (CURY, 2002).

No final do século XX, durante o período de abertura política (BELLO, 2001), ocorreu a promulgação da Constituição brasileira de 1988 e aprovação do projeto de lei para a nova LDB em 1996. A partir deste momento, surgiram várias iniciativas por parte do governo federal preocupado com a recuperação da escola fundamental, com o incremento da qualidade e avaliação dos sistemas escolares, mantendo a sua tradição histórica centralizadora nestas questões (CURY, 2002).

Assim, em 1997, foram definidos os parâmetros curriculares de abrangência nacional, conhecidos como PCNs, de modo a orientar as ações educativas do ensino obrigatório, além da busca pelo aprimoramento da qualidade do ensino nas escolas brasileiras. Neste sentido, a LDB destaca a necessidade de fornecer a todos uma formação básica comum, que deve fundamentar-se num conjunto de diretrizes capazes de nortear os currículos e seus conteúdos mínimos, incumbência que, nos termos do art. 9, inciso IV, é remetida para a União.

Além disso, foram lançados dois planos, em 2001, o Plano Nacional de Educação (PNE), e em 2007, o Plano de Desenvolvimento da Educação (PDE), marcados por um conjunto de ações visando a melhoria da qualidade da Educação nos seus diferentes níveis, principalmente, na Educação Básica. 
Retomando a questão do currículo escolar, segundo Almeida (2001), este pode ser conceituado, como um "instrumento que veicula idéias para uma melhor atuação dos professores"3 . Para tanto, nele estão embutidos: conteúdos, recursos pedagógicos e seus métodos de uso e aplicação.

Na visão de Moreira e Silva (2010), o currículo é um artefato social e cultural. Assim, as concepções de currículo estão relacionadas também a uma questão de identidade ou de subjetividade, pois vai além de uma questão de conhecimento e de poder, pois se trata de uma identidade.

Dentro deste contexto, os Parâmetros Curriculares Nacionais de $1988^{4}$ têm como objetivo maior o desenvolvimento das competências e das habilidades dos alunos. Trata-se de uma referência curricular básica para todo o país, no sentido de fomentar, escolas públicas e privadas, no trabalho de elaboração dos currículos e nas discussões sobre o projeto pedagógico das escolas. Assim, no corpo dos conhecimentos, estão os componentes curriculares (língua portuguesa, ciências, história/geografia, matemática, artes e educação física) e os temas transversais (saúde, ecologia, orientação sexual, ética e convívio social, pluralidade étnica, trabalho e economia) (CURY, 2002).

Os objetivos gerais do Ensino Fundamental, bem como os específicos de cada área, estão organizados, nos Parâmetros Curriculares Nacionais, em quatro ciclos. Cada ciclo corresponde a duas séries do ensino fundamental. Assim, vários estados e municípios, ainda na década de 1980, reestruturaram o ensino fundamental. A adoção desse sistema resultou em uma maior flexibilização da seriação, isto é, abertura de um período de tempo maior para o currículo, e o respeito aos diferentes ritmos de aprendizagens dos alunos, viabilizando assim, uma redução do número de repetências e evasões escolares.

\footnotetext{
${ }^{3}$ ALMEIDA (2001, p. 50)

${ }^{4}$ A Lei Federal n. 9394 de 1996 - a LDB (Lei de Diretrizes e Bases da Educação Nacional), usualmente denominada "Lei Darcy Ribeiro", determina como competência da União, o estabelecimento, junto aos Estados e Municípios, das diretrizes que orientem os currículos e seus devidos saberes, de forma a garantir uma formação básica comum a todos. Nesse sentido, foram elaborados os PCN's para o ensino fundamental (BRASIL, 1988)
} 
Os PCNs ${ }^{5}$ apresentam, também, de forma separada, os objetivos gerais de cada disciplina. Para o caso da Geografia do ensino fundamental, destacam-se, em termos gerais:

\begin{abstract}
- Conhecer e saber utilizar procedimentos de pesquisa da Geografia para compreender o espaço, a paisagem, o território e o lugar, seus processos de construção, identificando suas relações, problemas e contradições.

- Fazer leitura de imagens, de dados e de documentos de diferentes fontes de informação, de modo a interpretar, analisar e relacionar informações sobre o espaço geográfico e as diferentes paisagens.

- Saber utilizar a linguagem cartográfica para obter informações e representar a espacialidade dos fenômenos geográficos. (PCN, 2001, p. 122).
\end{abstract}

Para o primeiro ciclo ( $1^{a}$ e $2^{\underline{a}}$ séries) do ensino fundamental, o estudo da Geografia aborda, em especial, questões que envolvem a relação entre sociedade e natureza na construção do espaço geográfico. Dentro deste contexto, a paisagem local e o espaço vivido são o ponto de partida para o professor conduzir a sua ação pedagógica planejada.

O segundo ciclo ( $3^{\underline{a}}$ e $4^{a}$ séries) do ensino fundamental sugere um estudo voltado para as diferentes relações entre as cidades e o campo em suas dimensões sociais, culturais e ambientais. Considera ainda a relevância do papel do trabalho, das tecnologias, da informação, da comunicação e do transporte. Deseja-se com isso que os alunos percebam que as paisagens urbanas e rurais foram e ainda estão sendo construídas dentro de um processo histórico social e que acabam por sintetizar múltiplos espaços geográficos.

No terceiro ciclo (5 $5^{\underline{a}}$ e $6^{a}$ séries), o ensino de geografia deve retomar questões relacionadas à ação humana individual e em grupo frente à natureza, do papel da sociedade na construção do espaço. Busca-se uma maior autonomia do aluno em relação à observação, descrição, representação, explicação e compreensão do espaço e suas paisagens. Para tanto, o professor deve se servir dos diferentes recursos e linguagens com os quais possa obter viabilizar a mediação nas interações educativas, criando desafios para os conteúdos e atividades apresentadas, sem cercear os limites de sua interação de forma não anular a

\footnotetext{
${ }^{5}$ PCN de História e Geografia (2001), vol.5, p.122
} 
criatividade e motivação dos alunos. É sugerido que o professor trabalhe com diferentes tipos de mapas, com atlas, globo terrestre, plantas e maquetes.

Para o quarto ciclo ( $7^{\mathfrak{a}}$ e $8^{\underline{a}}$ séries) espera-se que o aluno seja capaz de compreender as relações entre sociedade, cultura, Estado e território e as contradições internas nos diferentes espaços não apenas para compreender o mundo, mas para construir paulatinamente o seu saber sobre o mundo.

Neste sentido, mudanças condizentes ao ensino e aprendizagem da Geografia retratam algumas posturas teórico-metodológicas, como a de privilegiar, num primeiro momento, o lugar, para em seguida estabelecer conexões com a realidade estadual, regional, nacional e global, com os devidos vai e vem para melhor entender o relacionamento entre o lugar e o todo mundial. O regionalismo e localismo retomam os seus postos de importância no momento em que apontam novos problemas e novos aparatos conceituais para a pesquisa geográfica.

Assim, o ensino da Geografia, ao investir no estudo dos lugares, das paisagens, território etc., tem proporcionado um trabalho interdisciplinar e buscado outras fontes de informação. Nos conteúdos da Geografia escolar, o estudo do lugar e o uso de mapas, constituem um dos objetivos do ensino em questão.

Os Temas Transversais e a ética, também fazem parte dos PCN's e apresentam certa complexidade em função da sua natureza diferir das demais áreas convencionais do saber. O que se deseja é que os temas transversais nunca sejam trabalhados de forma isolada, mas ao contrário, devem ser articulados com os objetivos e conteúdos, ou seja, é preciso que haja uma interação contínua, integrada e atual dos temas transversais nos conteúdos de todas as demais áreas distintas do saber $^{6}$. Assim, Ética, Meio Ambiente, Pluralidade Cultural, Saúde e Orientação Sexual são temas, que em seu conjunto, receberam a denominação de Temas Transversais $^{7}$. A escolha dos temas citados deu-se em função da urgência social, da abrangência nacional, da possibilidade de ensino e da aprendizagem no ensino

\footnotetext{
${ }^{6}$ É preciso levar em consideração que há afinidades maiores ou menores nas áreas do saber, como por exemplo: Ciências Naturais e Saúde ou entre História, Geografia e Pluralidade Cultural. PCN's, 2001. Vol. 8 p. 41

${ }^{7}$ O Tema Transversal, sob o título provisório: "Trabalho, Consumo e Cidadania" está na fase de elaboração, segundo os PCN's: apresentação dos temas transversais: ética/Ministério da Educação. Secretaria da Educação Fundamental. 3 ed. Brasília: A Secretaria, 2001. Vol. 08, p. 29.
} 
fundamental, e para favorecer a compreensão da realidade, das suas teias de relações histórico-social.

Deve-se deixar aqui bem claro que os PCN's não estão livres de críticas e questionamentos por parte de pesquisadores da área e de professores da rede de ensino. Candau (1999) discute a real proposta política por trás da reforma. Macedo (1999), por sua vez, levanta questões voltadas para a implantação dos temas transversais. E Pontuschka (1999), de igual forma, chama a atenção para o texto dos PCN's no sentido de que a linguagem utilizada nos textos dos PCN's é complexa e fora da realidade dos professores no Brasil:

[...] o texto é teórico demais para o professor que ainda utiliza o livro didático como a sua única ou principal bibliografia. Desse modo, ao lado dos PCNs, muitas outras ações precisam ser efetivadas para que o público-alvo possa elevar a qualidade de seu trabalho de acordo com os objetivos gerais previstos pelo MEC. (PONTUSCHKA, 1999, p. 16).

CACETE (1999) advoga que o processo de elaboração dos PCN's excluiu a participação e contribuição dos seus principais agentes: professores com suas experiências e saberes acumulados, alunos e sociedade civil através de suas entidades representativas. Para a autora,

\begin{abstract}
"A elaboração de um currículo nacional no Brasil demonstrou, e vem demonstrando, uma descabida obediência às prescrições do Banco Mundial na medida em que mantém uma postura elitista e centralizadora, entendendo o currículo como rol de conteúdos, que se baseia no modelo de ensino tradicional, separando conteúdo de método e privilegiando o primeiro, que considera os professores como meros receptores e executores passivos, que ignoram as reais condições do magistério no país e não levam em conta as experiências, conhecimentos, inquietudes e dificuldades do cotidiano do professor". (CACETE, 1999, p. 37).
\end{abstract}

A AGB desde 1996, também tem as suas ressalvas junto aos PCNs, no sentido de que o respectivo currículo tem caráter centralizador e hegemônico. Isto por descartar tanto as singularidades quanto as diversidades regionais e os saberes acumulados pelos professores em função do seu vivido, percebido e concebido junto aos seus alunos, onde o papel do professor é o de mediar o conhecimento e não apenas de transmiti-lo. Onde professores e alunos aprendem concomitantemente no momento em que questões são levantadas a partir da experiência do aluno, momento este que o professor o ajuda a reformular o seu conhecimento a partir da 
sua realidade, porém, com um embasamento teórico, capaz de revelar e aproximar ambos de uma realidade complexa.

Neste sentido, Dourado (2007) afirma que as políticas educacionais no Brasil, historicamente, caracterizam-se pela sua descontinuidade e centralização. Por descontinuidade, entende-se a ausência de planejamento de longo prazo e as ações sem articulação com os sistemas de ensino. Desta forma, deve-se buscar a organicidade das políticas, ações e programas, visando o ingresso, permanência e qualidade. Quanto à centralização, apesar dos avanços presentes na Constituição Federal de 1988, não houve elaboração de Lei Complementar para definir a colaboração entre os entes federativos (DOURADO, 2007).

Além do currículo escolar, deve-se também comentar acerca de outra questão relevante: a formação dos professores.

Ao analisar a formação dos professores, deve-se enfatizar que esta não se limita apenas à qualidade da sua formação inicial ou dos cursos de aperfeiçoamento realizados, mas abarca também um processo reflexivo e crítico sobre a prática educativa e as suas reais condições de trabalho, com o método de estudo e pesquisa apenas com base em livros didáticos. AGUIAR (2011, p.11) aponta que

[...] um dos argumentos para o estabelecimento de um currículo nacional,
segundo o documento introdutório, dos PCNs, são os baixos níveis de
formação dos professores. Temos que reconhecer que realmente, nas
últimas décadas houve um aligeiramento na formação do professor, através
dos cursos de licenciatura curta. No entanto não podemos nos esquecer
que esses cursos foram amparados pela Lei Federal n. $5692 / 71$ que institui
as licenciaturas curtas. Além deste fato, houve cursos de licenciaturas,
sendo oferecidos por algumas faculdades particulares em que o currículo
não atendia às necessidades de formação desses profissionais. Faculdades
estas reconhecidas pelo MEC.

Assim, entende-se que há professores que não puderam se dedicar integralmente à formação acadêmica em função da necessidade de conciliar estudo e trabalho, o mesmo acontecendo em relação aos cursos de capacitação ou especialização.

Com relação à questão docente, o atual Plano de Desenvolvimento da Educação (PDE), definiu ações que contemplam o aumento do piso salarial e a 
formação. Sobre a formação, estão previstos cursos de formação inicial e continuada, através da Universidade Aberta do Brasil. Contudo, estes cursos não são presenciais, mas de Ensino a distância, funcionando como mecanismo de certificação e não de qualificação (SAVIANI, 2007).

Como instrumentos para auxiliar a atuação do professor em sala de aula, destacam-se os recursos e práticas de ensino em Geografia. Neste sentido, os PCNs (1998, p.76), "[...] colocam para o geógrafo e para o professor de Geografia a importância da existência de recursos técnicos e didáticos que permitam, em seus estudos e pesquisas, a aproximação com seu objeto de estudo".

Os Atlas escolares, dentro deste contexto, apresentam-se como recursos didáticos de apoio reveladores, desde que a estrutura, a abordagem temática e os encaminhamentos de seu uso acompanhem as etapas do desenvolvimento mental da criança, como afirma Oliveira (1978). Sendo assim, os Atlas escolares não deveriam ser apenas uma mera coletânea de mapas

[...] mas sim uma organização sistemática de representações trabalhadas com a finalidade intelectual específica: são representações temáticas selecionadas, construídas a partir de dados consistentes, com o fim de revelar o conteúdo das informações sobre a atualidade, proporcionando ao estudante a compreensão de determinadas questões que a ele se colocam, em busca do conhecimento da realidade em que vive e o cerca. (MARTINELLI, 2011, p. 59).

Para o ensino da Geografia, o PCN (2001) ressalta a importância do ensino da alfabetização cartográfica a partir dos anos iniciais da escolarização, pois:

A imagem como representação também pode estar presente. Desenhar é uma maneira de se expressar. É uma característica desse segmento da escolaridade e um procedimento de registro utilizado pela própria Geografia. Além disso, é uma forma interessante de propor que os alunos comecem a utilizar mais objetivamente as noções de proporção, distância e direção, fundamentais para a compreensão e uso da linguagem cartográfica. (PCN, 2001, p. 129).

Entretanto, concordando com Almeida (2001, p.16), não se pode cercear a relevância dada pelo $\mathrm{PCN}$ de Geografia, em relação à valorização do uso de diferentes linguagens, dentre as quais, a do mapa, que aparece como uma linguagem passível de utilização para o ensino e aprendizagem de geografia. E, em 
especial, para o estudo do Lugar, que abre um leque de possibilidades para uma pesquisa mais aprofundada do espaço local como espaço cotidiano onde os conflitos mundiais se fazem presentes.

Entende-se nesse sentido, que os PCNs não deixam de ser um referencial de qualidade, e que embora o fato deles não contemplarem toda ação pedagógica necessária e desejada, eles são importantes para análise crítica e retomada das inúmeras discussões relacionadas tanto aos conteúdos quanto às metodologias a serem aplicadas em sala de aula.

Nesse sentido, na presente pesquisa se entende o espaço como "um conjunto indissociável de sistemas de objetos e sistemas de ações", como já comentado oportunamente. Pois, esse conceito permite trabalhar com recortes espaciais de análise, sob o ponto de vista de que a produção do espaço se dá dentro de um contexto histórico, em que a análise do lugar, permite compreender como se deram e se dão as relações de apropriação do espaço.

Nas orientações voltadas ao ensino e aprendizagem do e pelo mapa, entra-se no campo da Cartografia escolar. Lembra-se que a Educação permeia a Formação Docente e o Currículo, isto é, aponta os conteúdos, os recursos pedagógicos e os respectivos métodos de uso e aplicação, como já foram apresentados oportunamente.

Sobre este aspecto, Lastoria (2007), chama a atenção para o fato de a cartografia não constar ainda no Currículo Oficial do Ensino Fundamental e Médio como disciplina. A esse entendimento, acredita-se que seria o professor com formação de uma boa Licenciatura, onde nessa sim, houvesse uma disciplina de "Cartografia Escolar", que faria a diferença na vida dos seus alunos. Posição que se compartilha como já foi anunciado acima. Na verdade, as noções cartográficas, no Brasil, em especial, são ensinadas como um conteúdo curricular do programa de Geografia para as séries finais do ensino fundamental e médio. Lembrando que nos dois primeiros ciclos do Ensino Fundamental os conteúdos curriculares enaltecem o estudo da paisagem local, tendo o espaço vivido das crianças como o ponto de partida. 
Os avanços teórico-metodológicos na Educação brasileira, baseados nos trabalhos de Piaget e na Geografia vista na postura do materialismo histórico e dialético, na década de 1980, foram notáveis. Porém, a Geografia crítica apresentada em sala de aula por professores, não foi fruto de uma construção mental, pois a grande maioria dos professores tomou esse conhecimento para si, da mesma forma que seus alunos, isto é, através dos livros didáticos com seus conteúdos já estabelecidos como na Geografia Escolar Tradicional.

Segundo Straforini (2008), a Geografia Crítica apresentada em sala, não conseguiu romper com o conteudismo da escola tradicional, mas simplesmente passou de um discurso neutro para um dotado de criticidade, pois havia a crença que para ensinar bem e de forma atualizada, bastava o conteúdo de a matéria ser tratado de forma crítica. Uma retórica diferente! Os mapas, dentro deste contexto, aparecem como meros instrumentos didáticos, longe de serem instrumentos de pesquisa e distantes do entendimento de que por meio deles, seria possível obter pistas da realidade e do entendimento acerca de que compreender o todo mediante a conexão entre dados, é mais importante do que saber tudo. Vale lembrar que a realidade está inserida num todo, isto é, numa totalidade, onde o estudo fragmentado dela descompromete o aluno na sua formação para uma cidadania consciente.

Entretanto, tem-se aqui a acrescentar que uma forma dos alunos atingirem tais metas, antes será necessário que o seu professor também tenha condições de desenvolver e aprimorar o domínio de tais habilidades, através de uma formação contínua, coerente com a sua prática pedagógica e de acordo com as suas possibilidades na situação de protagonista deste processo.

SCHWARTZMANN e BROCK (2005, p. 38) afirmam que

[...] para enfrentar esta situação de complexidade crescente, é necessário também criar condições adequadas para o desenvolvimento da pesquisa em educação e fazer com que estes resultados sejam difundidos, conhecidos e incorporados às políticas governamentais.

No contexto apresentado desponta a necessidade de uma consideração mais incisiva a respeito da participação da Cartografia junto à Geografia. 


\subsection{Cartografia}

Tal como o da geografia, também o desenvolvimento da cartografia está atrelado à história do próprio homem, pois, à medida que a vivência espacial da pessoa foi se expandindo, esta, por vezes era registrada por incisões, pinturas ou montagens de estruturas. As mesmas foram feitas, sejam por uma questão de sobrevivência, conhecimento ou dominação, tanto em terras como em águas, fazendo dos mapas primitivos um legado e uma manifestação própria de cada povo, cultura, época e espaço. Desde os mapas primitivos o homem fez com eles Geografia (DUARTE, 1994).

A cartografia da antiguidade teve como mais evidente exemplo, o mapa da cidade Çatal Höyük, da Anatólia, Turquia, datado de 6.200 a.C. Um segundo mapa de destaque foi o grafito de Bedolina (Itália) gravado em um rochedo, reconhecido como de 2.500 a. C. A estes dois seguiu-se um mapa, não menos importante, de origem babilônica de 2.400 a.C., o qual atualmente se encontra no museu de Bagdá (Iraque). Tratava-se de uma placa de barro cozido com inscrições cuneiformes, representando, provavelmente, o vale do rio Eufrates.

A cartografia também floresceu do outro lado do mundo, na China, antes mesmo dela entrar em contato com outras civilizações. As primeiras referências a um mapa chinês datam de 227 a.C. Os remotos mapas de origem chinesa declaravam às claras uma nítida divisão social-territorial, pois estes vislumbravam um mundo concebido por zonas concêntricas, onde a China ocupava o centro do mundo, ficando a periferia para os bárbaros. Na verdade, quase todas as civilizações sempre tiveram o cuidado de colocar a sua, por coincidência ou não, no centro. ${ }^{8}$

Mas, foi no século $\mathrm{XI}$, conhecido como o das cruzadas, que a cartografia passou por profundas mudanças. As cruzadas intensificaram de certa forma a circulação comercial e marítima no mediterrâneo, impulsionada por mercadores e navegantes. O momento era propício para colher e registrar o maior número possível de dados das novas terras para transformá-los em informação. Neste sentido, os mapas serviam para registrar a localização dos pontos conhecidos e para traçar

\footnotetext{
${ }^{8}$ RAISZ, E. Cartografia Geral. 2 ed. Rio de Janeiro: Científica, 1964, 414p.
} 
outros que viriam a ser descobertos. Todo esse processo acabou por contribuir para a ampliação dos conhecimentos da Terra, gerando informações adicionais que colocaram em dúvida o contorno da Terra disseminado pela igreja Cristã da época.

No fim da Idade Média (século XIII) surgiram os mapas náuticos, mais conhecidos como cartas portulanos. A mais difundida destas é a Carta Pisana (1300), dotada de grande precisão e rigor científico para a época. São mapas orientados em relação ao norte magnético, representavam o Mar Mediterrâneo, o Mar Negro e o Oceano Atlântico, até a Irlanda. O sistema da Rosa dos Ventos e de rumos (direção da bússola) era um marco que também definia estas cartas portulanos. O objetivo delas era a navegação, de forma que os primeiros mapas apresentavam apenas a toponímia dos portos, cabos, detalhes das costas. Porém, à medida que aventureiros lançavam-se ao mar, traziam novos dados que iam aos poucos preenchendo os lugares vazios de tais mapas e até mesmo substituindo símbolos que serviam unicamente para mascarar o vazio dos mapas, ou ainda adorná-los.

Passando o ímpeto das descobertas das novas terras, as quais foram registradas em mapas, chegou o momento dos Estados modernos empreenderem uma reforma na cartografia (século XVII e XVIII), no sentido de acelerar o desenvolvimento desta ciência, motivados pelo desejo de, num primeiro momento, conhecer melhor suas novas aquisições e, logo em seguida, empreender obras estratégicas.

Assim, a passagem dos descobrimentos para a colonização (1560) propiciou o surgimento da figura do colonizador que se serviria da cartografia como instrumento estratégico de dominação para concretizar os planos da coroa. A profissão de cartógrafo passa a ser desejada pelos membros das melhores famílias da corte. Neste intento, surgem várias escolas voltadas para a cartografia. O saber cartográfico passou a ser eficiente para o conhecimento, a organização e a dominação do espaço.

Neste mister as grandes potências da época perceberam rapidamente que o momento pungia escolas especializadas em cartografia com a finalidade de formar e 
aperfeiçoar a ciência de se fazer mapas, marcando assim o início da ciência cartográfica moderna.

Vários motivos fizeram do século XVIII um dos grandes momentos da história da cartografia, ou ainda, da sua reforma. A academia real de Paris composta por astrônomos, matemáticos, cartógrafos foram convidados a revisar e corrigir a longitude, o comprimento da circunferência da Terra, bem como a sua forma, além de aperfeiçoar as técnicas cartográficas e os novos instrumentos de uso, tanto no mar (alidade e esquadros), como em terra (sistema de triangulação, alidade, que foi substituída pelo teodolito com luneta).

Grandes inovações foram propostas pelo astrônomo francês Cézar François Cassini de Thury (1714-1784). Ele foi o responsável pela reformulação da cartografia na França, além de eliminar informações não confiáveis. Para tanto, ele teve o cuidado de apoiar a sua cartografia em levantamentos geodésicos, topográficos e observações astronômicas. Neste intento, ele elaborou a primeira série sistemática de mapas topográficos para a França. Seus trabalhos tiveram reconhecimento e aproveitamento no exército.

Em um momento de grande desenvolvimento da indústria, da tecnologia, das invenções e dos transportes, da segunda metade do século XVIII até o fim do século XIX, com a divisão do trabalho, tal como se deu em tantas profissões, também na área científica operou-se uma divisão em ramos especializados. Este fato engendrou uma crescente demanda por mapas cada vez mais específicos para atender as solicitações das ciências emergentes. Estes mapas vieram a ser os que hoje são chamados de Mapas Temáticos. Assim, uma cartografia temática surgiu a partir do esforço em criar mapas "especiais" com temas de interesse das ciências, que foram se sistematizando, ou seja, com representações que foram se acrescentando paulatinamente aos mapas topográficos tidos como uma base de apoio para as localizações.

Assim, a cartografia passa a atender as solicitações das ciências. Por sua vez, a geografia fez também as suas cobranças tanto na área da geografia física como naquela da geografia humana. 
A institucionalização da Geografia, enquanto Disciplina curricular nos vários níveis de ensino no final do século XIX reconheceu os mapas como uma sua linguagem. Isto ficou bem comprovado com a publicação do livro "Le langage des géographes" de Fronçois de Dainville em 1964. Muito mais do que mapas geográficos isolados, tal institucionalização adequou o uso e aplicação de mapas organizados em atlas como recursos didático-pedagógicos no ensino e aprendizagem da geografia.

Embora a Alemanha tenha se adiantado, o clássico "Atlas général Vidal de La Blache, histoire et géographie" de 1894, induziu muitas derivações, tanto na França, como em outros países. No Brasil, o primeiro atlas escolar foi o "Atlas do Império do Brazil" de Cândido Mendes de Almeida, de 1868, antecedendo-se, portanto ao francês. Assim, os atlas tidos apenas como de "referência" ganharam uma nova conotação junto à sociedade, no momento em que neles foram incorporados mapas temáticos voltados a uma visão geográfica espacial integradora. Desta maneira, os "Atlas universais" passaram a concorrer com atlas em níveis escalares de maior detalhe ao incluir mapas temáticos específicos com o escopo de favorecer o entendimento sobre os mais variados espaços geográficos. O estudo do lugar no ensino da Geografia favoreceu uma grande profusão de atlas escolares para o conhecimento daquele.

O progresso da geografia quantitativa trouxe para a cartografia temática a necessidade de procedimentos mais apurados para o tratamento estatístico e gráfico de enorme volume de dados, assegurando-Ihe maior objetividade. Primeiro com as calculadoras eletrônicas, depois com os computadores, a cartografia se inseriu na era da informática, contando na década de 1960, com o início dos primeiros passos do processo cartográfico computadorizado e do estabelecimento da cartografia digital, os quais se efetivaram em função do potencial oferecido pelo computador.

Da junção entre cartografia e informática, resultou a proposta de inúmeros softwares. Considerados de forma agregada em sistemas, constituíram os Sistemas de Informações Geográficas - SIGs. Assim, a cartografia, na era da informação, deixou de ser apenas a arte de fazer mapas, passando, com base na sugestão de Taylor (1991, p. 214), a ser redefinida como: 
A organização, apresentação, comunicação e utilização da geoinformação nas formas gráficas, digital ou tátil, incluindo todas as etapas, desde o levantamento dos dados até o uso final de mapas, entendidos como produtos relacionados à informação espacial.

O autor estende a cartografia para o campo da informática.

Já para ACI (2003), indo mais adiante e valorizando o sujeito que a produz e não apenas o produto, a Cartografia seria definida como, uma

[...] singular habilidade para a criação e manipulação de representações visuais ou virtuais do geoespaço - mapas - para permitir a exploração, análise, entendimento e comunicação da informação sobre tal espaço.

Ressalta a cartografia como habilidade e não como uma ciência.

O já citado Taylor, para 2009 coloca a cartografia como sendo:

[...] a organização, apresentação, análise e comunicação da informação espacial georreferenciada numa ampla gama de tópicos de interesse e uso para a sociedade num formato interativo, dinâmico, multimídia e multisensorial.

Que seria aplicada a uma ampla variedade de temas de estudo.

Para o caso do mapa, a mesma associação o entende como

[...] "uma representação simbolizada de uma realidade geográfica, reproduzindo feições e características selecionadas, resultantes do esforço criativo da execução de escolhas por parte de seu autor, sendo destinada para uso quando as relações espaciais são de elevada relevância" (ACl, 2003).

Ressalta a temática a ser tratada, amplia as possibilidades da aquisição do conhecimento, além de ter evidenciado a importância das aplicações.

Como um acréscimo metodológico a uma cartografia desejosa de se tornar mais científica, dentre várias lucubrações e, em especial, antes mesmo da proposta da "comunicação cartográfica" da década de 1960, despontou não distante daquele 
contexto, a proposta de Jacques Bertin. Com esta postura, o estudioso desenvolveu as bases para uma gramática de uma linguagem gráfica, não só do mapa, como também do gráfico e da rede, a "Representação gráfica", com bases alicerçadas nas propostas de Ferdinand de SAUSSURE para a linguística.

Portanto, levou a cartografia para uma concepção estruturalista. Estabeleceu, assim, em paralelo à semiologia, a teoria geral dos signos, uma "Semiologia gráfica", que seria específica aos signos gráficos. A idéia era chamar a atenção dos estudiosos, inclusive dos geógrafos, para a reflexão e a prática sobre o uso da representação gráfica em suas pesquisas. No campo da geografia era preciso que os geógrafos e outros cientistas praticassem uma cartografia mais analítica do que descritiva, com maior cuidado na sua sintaxe, semântica e pragmática. Que tais estudiosos pensassem no mapa, enquanto uma parte racional e eficiente das imagens, pois "[...] eles fazem parte de um sistema de signos que o homem construiu para reter, compreender e comunicar as observações necessárias à sua sobrevivência". (BERTIN, 1973).

Com sua propositura, o mesmo autor ressaltava que os mapas, gráficos e redes, como construções gráficas, integrariam um domínio específico, o da Representação Gráfica, o qual se inseriria, por sua vez, naquele da Comunicação Visual, que integra a comunicação social. Pelo fato de se estar mobilizando uma estrutura específica, o sistema semiológico monossêmico, contar-se-ia com uma sua grande particularidade, a de enaltecer a relação entre os significados dos signos, não se atendo apenas à relação entre o significado e o significante do signo, tarefa já realizada pela legenda da representação gráfica.

A representação gráfica tem a proposta de transcrever as três relações fundamentais que podem se dar entre objetos, fatos e fenômenos a representar dentro de uma postura sobre a realidade problematizada pelo autor: de diversidade $(\neq)$, de ordem $(O)$ e de proporção $(Q)$, por relações visuais de mesma natureza $(\neq, O$ e Q). Segundo o mestre, este seria o único caminho para o mapa, o gráfico e a rede deixarem a categoria de meras ilustrações, e passarem a orientar o discurso sobre o que se descobriu acerca da realidade, promovendo sua compreensão e por consequência, seu conhecimento. 
Bertin (1973) considera ainda, que fazer um mapa significa explorar sobre o plano bidimensional as correspondências entre todos os elementos de uma mesma componente espacial da informação - as localizações dadas em coordenadas geográficas. É o componente locacional. As duas dimensões $(\mathrm{X}, \mathrm{Y})$ do plano identificam a localização do lugar (Longitude e Latitude). Caracterizam a ordem geográfica: a localização de Sorocaba não pode ser permutada com a de São Paulo. É o domínio da cartografia topográfica. É a base cartográfica (BERTIN, 1973, 1977).

Entretanto, os mapas podem dizer muito mais sobre cada lugar, além de apenas responder à questão “Onde fica?", caracterizando-os. Este é o domínio da cartografia temática.

A fim de representar o tema, seja no aspecto qualitativo $(\neq)$, ordenado $(O)$ ou quantitativo (Q), seja com manifestação pontual, linear ou em área, exploram-se em mapa, variações visuais sensíveis com propriedades perceptivas compatíveis, o que constituiria a modulação de uma terceira dimensão visual.

A partir do raciocínio acima apresentado, os métodos de representação gráfica para o caso dos mapas junto à cartografia temática deverão se adequar à representação das relações entre objetos, fatos e fenômenos da realidade. Assim, o aspecto qualitativo $(\neq)$ responde à questão "o quê?", caracterizando relações de diversidade entre os conteúdos dos lugares, caminhos ou áreas. Para abordá-los empregam-se métodos de representações qualitativas. O aspecto ordenado $(O)$ responde à questão "em que ordem?", caracterizando relações de ordem entre os conteúdos dos lugares, caminhos ou áreas. Para mostrá-los mobilizam-se métodos de representações ordenadas. O aspecto quantitativo (Q) responde à questão "quanto?", caracterizando relações de proporcionalidade entre os conteúdos dos lugares, caminhos ou áreas. Para explorá-los utilizam-se métodos de representações quantitativas.

Tais métodos de representação, estabelecidos durante o século XIX e que seriam usados para representar os fenômenos que compõem a realidade a ser exposta em mapa, podem ser viabilizados sob o ponto de vista estático ou dinâmico, solicitando para tanto, contribuições respectivamente, da cartografia estática ou cartografia dinâmica. 
A realidade, objeto de representação, pode ser vislumbrada dentro de um nível de raciocínio analítico (caracterização dos lugares, caminhos ou áreas por seus atributos ou variáveis), bem como de síntese (identificação e delimitação de agrupamentos de lugares, caminhos ou áreas unitárias de análise caracterizadas por agrupamentos de atributos ou variáveis).

Depois de prontos os mapas em suas várias modalidades de expressão, podem oferecer, quanto ao grau de apreensão, uma apreciação em nível elementar ou de conjunto.

Maiores detalhes sobre estes encaminhamentos serão apresentados em item mais específico junto ao Capítulo III.

Dentro de uma visão mais recente, podendo ser vista como complementar às anteriores, para Taylor (1994), a atual cartografia deve ser abordada dentro do contexto da era da informação, congregando a visualização científica, que será a grande responsável pela revitalização da cartografia moderna e certamente conduzirá a uma nova relação entre a cartografia e a geografia.

Neste mister, a visualização cartográfica legitima o seu papel como conceito central para a cartografia da atualidade, interligando não apenas a cognição e a análise, a comunicação e as tecnologias computacionais, mas também a interação e a animação. Estas duas últimas propriedades, sendo operadas na internet, oferecem aos mapas um forte potencial de comunicação.

Para Rheingans (apud MARTINELLI, 2011, p. 256), "A Visualização é a ciência da representação visual de dados para lhes assegurar a comunicação ou a compreensão". Aqui se coloca a questão central de fazer com que a representação gráfica dos dados mediante mapas no campo da geografia seja realizada como forma de adquirir conhecimento. Crê-se, assim, que se estaria compondo uma Visualização científica. É certo que os mapas não podem e não devem ficar à margem do contexto da era da informação, que aponta o citado conceito como o maior da cartografia hodierna, o da Visualização cartográfica.

O campo da visualização cartográfica tem experimentado um grande crescimento nos últimos anos. Em substituição aos mapas estáticos, a animação e 
os ambientes virtuais, estes proporcionando alto nível de imersão e interação, são empregados para a exploração e a representação de dados geoespaciais. Dessa maneira, a Animação e a Realidade Virtual ${ }^{9}$ têm se apresentado como instrumentos de grande potencial na cartografia, buscando minimizar a diferença entre o mapa e a realidade.

A cartografia sempre procurou representar a realidade tridimensional, por duas dimensões, as do plano. Porém, com o desenvolvimento tecnológico ocorrido nas últimas décadas, surge um novo desafio, que é representar tridimensionalmente este mesmo mundo em um ambiente computacional. Além de trabalhar agora com uma representação tridimensional, diferente dos mapas convencionais, que são estáticos e bidimensionais, a cartografia pode, ainda, ser dinâmica, com a possibilidade de contar com uma ativa interação do usuário.

Esta nova forma de representar o mundo busca trazer a realidade de forma mais facilmente concebida ao usuário, além de proporcionar a ele a sensação de fazer parte da mesma, ao nela se imergir.

Todas essas inovações continuam exigindo dos geógrafos e outros usuários, o conhecimento da geografia para desenvolver estudos da realidade sócio-espacial, entrevendo correlações entre fenômenos, além de promover sínteses geográficas e cartográficas. Tais exigências implicam, não apenas no treinamento para a manipulação de programas para cartografia, como também o correto tratamento e representação gráfica de grande quantidade de dados de variada natureza, demandando o emprego de uma coerente gramática de sua linguagem, bem como a escolha certa da escala a ser usada, além da indicação de uma opção metodológica em Geografia.

A par das considerações sobre a cartografia apresentadas até aqui, deve-se apontar também para uma linha de apreços críticos que surgiram na Pósmodernidade, desde o final da década de 1980. Assim, os mapas não seriam

\footnotetext{
${ }^{9}$ Segundo MACHADO (1995), a Realidade Virtual pode ser definida como "um conjunto de métodos e técnicas capazes de permitir a integração sensitiva entre o usuário e o computador, objetivando dar a este a máxima sensação de presença no mundo virtual. Em geral, refere-se a uma experiência imersiva e interativa, baseada em imagens gráficas tridimensionais geradas em tempo-real por computador."
} 
exatamente iguais à realidade, senão uma representação particular dela, portanto, uma representação parcial do que realmente existe, carregando muito da visão de mundo do autor Há desse modo, um cruzamento entre saber e poder (LAMA, 2009, p.123).

Tendo como um dos primeiros estudiosos a colocar um olhar crítico sobre os mapas, John Brian HARLEY (1989), outros autores também fizeram exposições com esta apreciação.

Assim, passou-se a avaliar os mapas tentando desfazer sua neutralidade, considerando-os como formas de ver o mundo, social, cultural e historicamente construído. Ver-se-iam os mapas como formas de saber socialmente construído, não sendo, portanto, imagens isentas de julgamento e valor.

Pesquisadores da atualidade sugerem se fazer uma leitura crítica dos mapas, da mesma maneira como se pode fazer aos textos, entrevendo o discurso a que se propõem, onde transparece sua retórica.

\subsubsection{Cartografia Escolar}

Segundo AGUIAR (2012), a Cartografia pode se constituir num vínculo importante entre a produção e a transmissão do conhecimento na Escola. Neste sentido, a combinação adequada entre a narrativa oral e a visualização propiciará as condições necessárias para o exercício da imaginação geográfica. No entanto, a mesma ressalta que a Cartografia somente servirá como linguagem conceitual da Geografia se houver articulação teórica e metodológica entre Geografia e Cartografia. 
ALMEIDA (2001, p.09), por sua vez, coloca que o escopo da cartografia escolar transita entre três áreas científicas: Cartografia, Educação e Geografia. A cartografia participa mediante seus conceitos cartográficos, linguagem gráfica, suportes e materiais. A educação está presente com o currículo, formação docente, aprendizagem e métodos de ensino. A geografia por sua vez, compreende os conceitos socioespaciais, relações sociedade e espaço e as representações espaciais. Portanto, trata-se de uma área de ensino e de pesquisa. Para tanto, ela busca entender os procedimentos de ensino aprendizagem do mapa e pelo mapa, respeitando os processos cognitivos do escolar.

A professora Lívia de Oliveira apresentou um estudo metodológico e cognitivo do mapa, ressaltando a importância do preparo solidário do aluno para o entendimento do mapa, fruto da sua tese de livre-docência, em 1978. Essa pesquisa acabou por contribuir nos estudos de outros pesquisadores interessados em pesquisar os mecanismos perceptivos e cognitivos que a criança busca ao mapear.

AGUIAR (2011, p. 49) aponta que fruto do estudo da Professora Lívia de Oliveira de 1978 sobre uma lucubração metodológica e cognitiva do mapa, desencadeou-se na década de 1980 , além da produção didática de mapas, uma nova época na elaboração de atlas escolares no Brasil. Buscou-se maior interação com as propostas de ensino e aprendizagem da geografia, culminando na década de 1990 com uma maior difusão dos atlas locais e municipais, condizentes com os PCN, que se propuseram a indicar a reflexão teórico-metodológica para o ensino de geografia.

Tomoko I. Paganelli, por sua vez, apresenta uma contribuição significativa para a cartografia escolar através de um estudo aprofundado da representação do espaço sob o ponto de vista piagetiano, no qual discute o conhecimento e domínio do espaço por crianças em faixa etária na qual se espera que esteja resolvido as relações espaciais a nível concreto. Estudo que resultou em sua dissertação de mestrado intitulada "Para a construção do espaço geográfico na criança", apresentada e defendida em 1982. 
Outros pesquisadores da área como Maria Elena Simielli, Janine G. Le Sann, Elza Y. Passini, Rosângela Doin de Almeida, Marcello Martinelli, Mafalda N. Francischett, Sônia V. Castellar dentre outros com a mesma ou semelhantes linhas de pesquisa contribuíram para o aprofundamento da cartografia escolar no Brasil.

Assim, esses estudos no Brasil já vêm sendo feitos há um bom tempo, tendose iniciado com uma reunião de discussão sobre o assunto em 1995 por ocasião do $1^{\circ}$ Colóquio Cartografia para Crianças em Rio Claro (SP). No entanto, a cartografia escolar vai alcançar um desenvolvimento significativo somente a partir da década de 1990, em função dos encontros e colóquios internacionais, considerados momentos oportunos para a divulgação de pesquisas relacionadas "às práticas educativas com mapas", fundamentadas na Teoria Psicogenética de Piaget, na produção do espaço social de Henri Lefèbvre e na Semiologia Gráfica de Bertin. (AGUIAR, 2012, p.271).

Outros se seguiram até o presente momento. Neste campo de estudo, pesquisadores divulgaram outros trabalhos mais específicos, tendo emergido dentre eles contribuições sobre a elaboração dos atlas escolares em nível de município, confirmando a adoção da categoria lugar para a compreensão de seu vínculo com o mundo (ALMEIDA, 2001).

Para a cartografia escolar, no âmbito internacional, conta-se com a Comissão sobre Cartografia e Crianças (Commission on Cartography and Children) da Associação Cartográfica Internacional (ACl) - International Cartographic Association (ICA).

Dentro do que foi exposto, "[...] a Cartografia Escolar possibilita pensar significativamente o conhecimento do espaço geográfico através da leitura e entendimento das representações cartográficas para além do objeto, ou seja, na constituição de seu significado." (FRANCISCHETT, 2007: 1). Contudo, professores e alunos apresentam ainda grande dificuldade no domínio dos conteúdos de cartografia. ALMEIDA (2010) aponta que no processo da formação do professor, há necessidade de que seja embutida a cartografia escolar nos cursos de capacitação. Lembra também que há tempo a cartografia escolar vem se estabelecendo na interface entre cartografia, educação e geografia. Assim, conceitos de cartografia 
vêm ocupando lugar no currículo e nos conteúdos de disciplinas voltadas para a formação do professor.

Outro campo que marca a presença da cartografia escolar é o do livro didático de geografia, onde se podem destacar exemplos de acurada veiculação.

Estes livros com um início junto à reprodução de figuras, mapas e gráficos em branco e preto, aos poucos foram ganhando mais veracidade com os avanços da reprodução a cores, com esmerados cuidados nas artes gráficas, proporcionando aos escolares um mundo a ser estudado, agora colorido.

Por outro lado a evolução do pensamento geográfico através do tempo foi tomando medidas específicas com relação aos mapas que se apresentariam em tais livros didáticos. De uma postura positivista com a descrição, a enumeração e a classificação da realidade em mapas pretendeu-se passar para uma cartografia em prol de um espaço mais justo, que seja constituído com base nos méritos da sociedade.

Francischett (2010) ao fazer uma análise da participação do mapa no Livro didático de geografia, em primeiro lugar vê este, não apenas como material didático, mas sim como veículo de comunicação com a capacidade de formar opiniões. $O$ mapa não profere uma alocução qualquer, em sua fala discursa sobre um espaço social com a autoridade de tal agente de transmissão, sendo porta voz dos mais conceituados intelectuais. 
CAPÍTULO II

OS ATLAS EM GERAL E OS ATLAS ESCOLARES 


\section{CAPÍTULO II - OS ATLAS EM GERAL E OS ATLAS ESCOLARES}

\subsection{Os atlas em geral}

A origem dos atlas remonta ao início da era cristã, aparecendo sob a forma enciclopédica, muitas vezes incluindo mapas históricos e geográficos. O primeiro atlas que se tem conhecimento é o de Ptolomeu tido como um anexo à sua obra Geographia datada do século II. Como uma coletânea de mapas, seu conteúdo revelava uma intencionalidade ligada às necessidades da época: conhecer o mundo e localizar lugares.

Coleções de mapas como esta, tinham mais o propósito de agrupar mapas em um único volume, tornando prático seu manuseio, do que entrever alguma finalidade intelectual que pudesse ser enaltecida mediante tal arranjo.

A história da afirmação dos Atlas como constructos do intelecto teve propriamente seu início na passagem do século XV para o XVI, com a afirmação dos avanços da cartografia no Renascimento. A invenção da gravação, primeiro em pedras, depois em metais também colaborou para tal desenvolvimento, barateando os custos de reprodução dos produtos concluídos.

Embora muitas obras cartográficas tenham sido realizadas em toda a Europa, no que tange aos Atlas vistos como coletâneas, aqueles dos Países Baixos ganharam grande repercussão devido ao empreendimento de suas editoras através de várias edições sucessivas. Uma das primeiras foi aquela de Abraham Ortelius, com o título "Theatrum Orbis Terrarum", editada em 1570. Sua originalidade como Atlas o destacou dentre os demais até então produzidos. Foi considerado o primeiro Atlas geográfico moderno. Reuniu tudo quanto os contemporâneos do autor já haviam escrito sobre a Terra. 
Seguiu-se a este, a coletânea de Gerard de Jode, intitulada "Speculum Orbis Terrarum" de 1578. Logo depois apareceu a coleção mais famosa, a de Gerhardt Kremer - o Mercator - organizada e editada após sua morte por seu filho, em 1595. Nomeou-a de "Atlas Sive Cosmographicae Meditationes de Fabrica Mundi et Fabricati Figura". Usou-se assim, pela primeira vez, o termo "ATLAS" para designar um conjunto de mapas. Mercator deu-lhe este nome ao comparar o esforço empreendido em sua obra, na qual trabalhara de 1569 até sua morte em 1595, àquele que a fábula atribuiu a Atlas.

Na mitologia grega, Atlas era um Titã revoltado contra os deuses. Por ter tomado parte na luta dos Titãs contra aqueles, fora condenado por Zeus a sustentar nos ombros a abóbada celeste. Assim Mercator decorou o frontispício de sua produção com uma figura do herói legendário, porém substituindo a esfera celeste pelo globo terrestre!

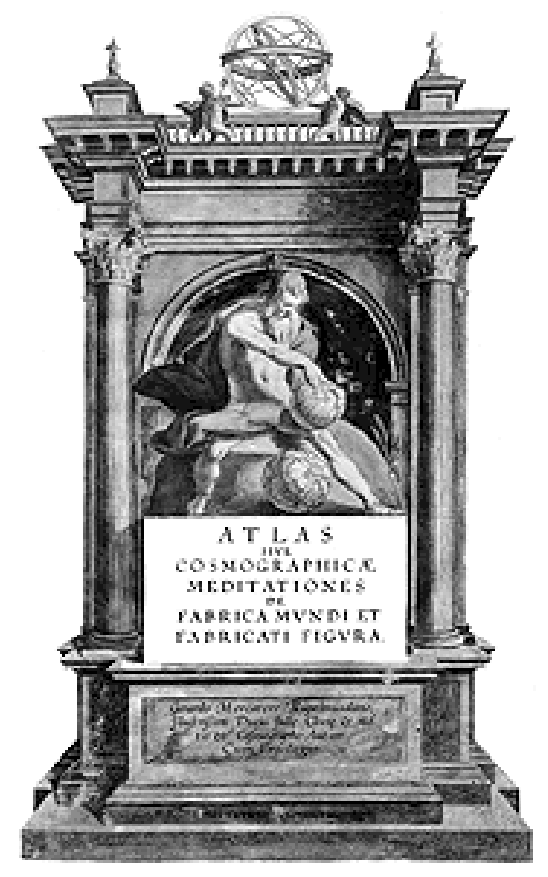

Figura 2 - Frontispício do Atlas de Mercator.

Na segunda metade do século XVII, por conta dos avanços capitalistas na Europa destacaram-se várias realizações em termos de Atlas. O marechal Vauban, por ser engenheiro militar além de economista, propôs em seu tratado econômico "Projet d'une dîme royale" criar um "Atlas da França" (1698), que deveria mostrar 
tudo o que havia de importante no território francês para o supremo mandatário e, assim tornar-se merecedor de maior atenção naquele reinado. Vauban teria inventado os Atlas nacionais e regionais (LIBAULT, 1967).

A necessidade de procurar conhecer e representar o mundo, por meio dos atlas universais, se fez desde então, sempre presente. No final do século XVIII, a idéia de "ocupação e dominação de novos territórios" passou a exigir um conhecimento mais detalhado de cada parte do mundo. Assim, emergiram os atlas nacionais como uma necessidade imperativa para a época, sendo, um pouco mais tarde, complementados, pelos regionais por conta de atender a uma abordagem mais detalhada.

Para Raisz (1953, p.271) atlas é "[...] uma coleção de mapas, formando geralmente um volume, publicado em um mesmo idioma, com simbolismo uniforme e idêntica projeção, mas não necessariamente na mesma escala". Aqui, tem-se uma definição cartográfica ou técnica: simbolismo, projeção e escala. Mas, mesmo assim, ela revela a questão da escolha da escala que deve ser vista, também, de forma qualitativa.

Pode-se, também, considerar como definição de atlas aquela dada por Aurélio Buarque de Holanda Ferreira (1999), como "coleção de mapas ou cartas geográficas em volume". Nessa definição, ele enfatiza: a coerência, o estado de estar completo e diversidade de representação. Isto é, mapas e cartas. Outra definição seria aquela dada por Cêurio de Oliveira (1987) para atlas que diz: "Coleção ordenada de mapas, com a finalidade de representar um espaço dado e expor um ou vários temas". Aqui, tem-se uma escolha metodológica de um ou mais temas e a forma de representação dos mesmos.

Assim, dentro dessas definições fica claro que há uma intencionalidade do autor do atlas, seja pela escolha e ordem dos temas, pela decisão da escolha da escala e pelo uso de diferentes representações gráficas, como mapas e/ou gráficos. Tudo depende do que se quer informar e comunicar. Entretanto, o caráter intencional do atlas pode ser amenizado ao se considerar o aspecto léxico no atlas, isto é, o atlas enquanto fonte de pesquisa para localizar lugares que estão indicados no índice de nomes. Segundo Sandford (apud ALMEIDA, 2001, p.6), os atlas 
comportam uma coleção de mapas gerais (físicos e políticos). Tais mapas apresentam muitos topônimos, daí serem chamados de "mapas léxicos" e são complementados por mapas temáticos, figuras, diagramas e textos.

Recentemente, está-se assistindo a uma grande diversidade de meios na produção de atlas: impressos em papel e encadernados, digitais e eletrônicos, possibilitando a interatividade, a animação e a realidade virtual. Os atlas podem ser compostos não apenas por mapas, mas também por textos, tabelas, fotografias, infográficos, gráficos e redes. Assim, o conteúdo, a forma de uso do Atlas, o acesso à informação, a possibilidade de comparação de mapas, as formas de interação e a própria produção, certamente são questões importantes que requerem um arcabouço teórico-metodológico direcionado aos profissionais da área, estudiosos e usuários.

Percebe-se que, paulatinamente, as grandes inovações tecnológicas no mundo, influenciaram a forma de pensar, construir e empregar os mapas e, por consequência, os atlas geográficos também. Segundo Delazari um ponto importante para a visualização é a interatividade na cartografia, proporcionando ao usuário maior abertura em uma possível recomposição, como a simbologia a ser utilizada, a escolha das escalas etc. O surgimento do CD-ROM e da Internet (décadas 1980/90) favoreceram um satisfatório desenvolvimento na área da multimídia. Dentro deste processo, com base na Associação Cartográfica Internacional a eficácia do mapa vai além da comunicação, voltando-se, sobretudo à revelação e percepção dos fenômenos espaciais, pois se serve desses instrumentos para proceder a análises visuais, no processo denominado de visualização cartográfica apontado anteriormente (ICA, 2001; OLIVEIRA, 2002).

Mesmo na sua forma mais simples e usual, impressa em papel e encadernado, o Atlas geográfico é do maior interesse, ganhando crédito nas aulas de geografia. Com certeza configurar-se-ia como recurso didático-pedagógico. Entretanto, é preciso que profissionais além de professores e usuários não se atenham apenas às formas dos fenômenos representados em seus mapas, mas também avaliem o seu respectivo conteúdo. Kraak e Ormeling (1998) discutem a relevância do conteúdo e a forma de uso dos atlas para o caso dos eletrônicos. Ambos entendem que o conteúdo deve ser analisado em função da finalidade ou 
propósito do usuário. Pensa-se que o mesmo se aplica aos atlas em geral. Assim, com base nos autores citados, é preciso questionar "O que está no atlas?", "Qual é o conteúdo topográfico e temático de seus mapas?"; "Qual a região e a época da representação?". A forma de uso do atlas, por sua vez, deve ser trabalhada com base em perguntas como: "Quem usa o atlas e como?"; "O atlas é projetado para usuários com conhecimento sobre os temas e tópicos que estão sendo apresentados?"; “Os usuários, talvez especialistas em seu campo, sabem como interpretar padrões apresentados no mapa?". Perguntar-se-ia, agora, como seria no caso dos escolares. Acredita-se na validade das mesmas perguntas.

É neste ponto que ganha validade a elaboração de um "Manual do professor", acompanhando o Atlas, o qual poderá, primeiramente, elucidar as bases do aprendizado do mapa, depois empreender o aprendizado pelo mapa com leitura, análise e interpretação dos mesmos (vistos separadamente ou em comparação entre temas vinculados) e, por fim, oferecer roteiros de trabalho.

Nimer et al. (1988) salientam que os atlas devem fornecer informações sobre os recursos naturais presentes e exibir a organização espacial da sociedade, bem como retratar as mudanças ambientais decorrentes. Esta proposta dos autores dá um consistente encaminhamento para estruturar conteúdos dos atlas. Foi adotada no "Atlas Nacional do Brasil", 3ํㅗㄹ edição, de 2000. Outro aspecto relevante é o recorte espacial. Um atlas escolar pode representar um determinado bairro, cidade ou município. Evidentemente, que a abrangência pode ser maior em se tratando de um país, continente e até do mundo. Vinculado a este recorte estaria a definição da escala de seus mapas.

Percebe-se que, apesar de existirem diferentes formas de compor atlas, a busca por uma metodologia de atlas constitui-se, já de há tempo, num desafio tanto para estudiosos como para editores de atlas.

\subsection{Os Atlas escolares}

No ambiente de ensino e aprendizagem da geografia, desde a sua instituição como disciplina escolar, primeiro na Alemanha e depois na França, na segunda 
metade do século XIX, seguindo o modelo da geografia alemã, os atlas geográficos escolares ganharam crédito entre os materiais didáticos, adequando-se cada vez mais a esta tarefa em sala de aula (AGUIAR, 1996, 2011; MARTINELLI e MACHADO-HESS, 2011).

O Kleiner Atlas Scholasticus, publicado na Alemanha, em 1710 pelo editor Homann, teria sido um dos primeiros atlas escolares. No entanto, tal atlas não foi uma iniciativa isolada. Na França, o Petit atlas géographique du premier âge, de Cortambert, editado pela Hachette, em 1840, foi considerado como o primeiro atlas voltado para o ensino fundamental daquele país. Criou-se, assim, uma tradição do uso de tais construtos por alunos e professores como apoio às aulas para se tratar temas da geografia, ao nível de ensino a que se destina, embora muitas vezes eles estivessem muito próximos das simplificações dos conhecidos Atlas gerais de referência.

Convém destacar que boa parte dos atlas escolares, agora já sendo produzidos em pleno século $X X$, foi inspirada no "Atlas général Vidal-Lablache: histoire et géographie" de 1894, o que pôde ser observado tanto na França quanto em outros países do continente europeu. O autor, na época, colocava primeiro o mapa político o qual deveria ser complementado pelo físico, tecendo comentários em texto sobre a questão.

Já o Atlas de géographie physique, politique et historique de GrosselinDelamarche, editado em Paris em 1896, foi dirigido especificamente aos cursos de geografia e história franceses.

No Brasil, como já foi anunciado oportunamente, o primeiro atlas escolar a ser publicado foi o de Cândido Mendes de Almeida, em 1868, adiantando-se até em relação ao congênere francês. Esse atlas, composto basicamente por mapas políticos, foi desenvolvido com o objetivo de expandir o conhecimento e importância acerca das fronteiras do Império. O público-alvo foram os alunos do ensino secundário, em especial, os do Colégio Pedro II do Rio de Janeiro (AGUIAR, 1996).

Até a década de 60 os atlas escolares, no Brasil, contemplavam as mesmas especificidades dos atlas mais antigos, principalmente os gerais de referência. 
Refletiam bem a Geografia daqueles momentos. Herança de uma época em que a Geografia se avizinhava à cosmografia. Assim, tais atlas apresentavam primeiramente as noções de astronomia (universo, sistema solar, Terra, Céu, Lua), depois vinham os planisférios, em seguida, os mapas regionais do mundo e por fim, os mapas temáticos do Brasil, chegando até às plantas de cidades. Traziam a ideia do entendimento do geral para o particular. Como exemplo, cita-se o "Atlas Geographico geral e especialmente do Brasil" (Atlas Geográfico Melhoramentos) de PAUWELS, com sua primeira edição de 1936, reeditado com algumas alterações em 1944 e depois em outras publicações, como a de 1994 (Jornal da Tarde), seguindo até hoje com inovações que a editora as considera plausíveis. Trata-se de um atlas clássico, idealizado dentro dos parâmetros europeus do século XX que enfatizava a Geografia física e a dos lugares. É um atlas que está no mercado com novas edições, com maior número de mapas temáticos, principalmente do Brasil e dados geográficos atualizados. Porém, apresenta poucas alterações na sua concepção teórico-metodológica.

Os atlas escolares publicados entre as décadas de 1960 e 1980 começaram a dar indícios de mudanças na forma de ver e entender o atlas. Entretanto, ainda estavam presos à localização dos lugares.

Um atlas com abordagem bem distinta deve ser mencionado. O Atlas de RODRIGUES (1977) constituiu um verdadeiro modelo para outras publicações do gênero que se seguiram. Sua especificidade estava em ter um formato cômodo de manuseio pela criança, além de contar com um conteúdo objetivo, consoante com o programa da disciplina. Era um atlas para Estudos Sociais, matéria obrigatória da época. Acompanhava o volume um pequeno Guia do professor, colocando primeiro, noções e práticas básicas da cartografia e depois, uma orientação didática para utilização do atlas, disponibilizando para cada tema abordado, os objetivos, observações sobre a visualização dos mapas e exercícios.

Na década de 1980, os atlas escolares começaram a ter mais cuidado em apresentar mapas temáticos na mesma escala, facilitando a leitura e correlação entre fenômenos expostos em vários mapas. 
Essa concepção de atlas escolar, com certeza, auxiliaria no processo ensino/aprendizagem de Geografia, visto estar mais consentânea com as novas propostas teórico-metodológicas da Geografia que têm buscado uma abordagem integrada do espaço geográfico, possibilitando a análise e o conhecimento, sob dimensões múltiplas, de um mesmo lugar. Essa linha de produção extrapola a simples cartografia de localização. (AGUIAR, 1996, p. 178-179)

Assim, o conhecimento metodológico voltado para a confecção de atlas geográficos escolares passou a ser pautado em um processo historicamente construído, não apenas como algo a ser reproduzido, mas a ser modificado, reconstruído e que contemple uma dimensão política e social, pautada na realidade. Os atlas escolares são frutos não apenas da evolução e transformação epistemológica da geografia, da cartografia e da educação, mas também da afirmação de uma economia de mercado cada vez mais globalizada. A supremacia do poder econômico e tecnológico e as relações de poder entre os países e mesmo no interior de cada nação apresentam grandes repercussões e desafios inclusive no campo educacional. Entretanto, recentemente, conta-se com uma considerável quantidade e variedade de atlas escolares entre os recursos didáticos, seja nos formatos impressos, digitais e eletrônicos, seja mundiais, nacionais, estaduais, municipais e inclusive os locais. Toda esta gama escalar busca uma flexibilidade maior na seleção dos seus conteúdos para que professores através da sua prática intencionalizada junto aos seus alunos intervenham nele a partir da sua realidade mais próxima para contextualizá-la na integração com outros lugares, portanto, o mundo.

Assim, a confecção de atlas escolares embute um campo de conflito na escolha do método de pesquisa no campo do saber da Geografia (conteúdo dos atlas), da Cartografia (método de representação) e da Educação (ensinoaprendizagem), e em torno de duas dimensões centrais da cultura: as ideologias e as relações de poder perante a seleção do conhecimento a ser revelado nos mapas que compõem os atlas. Assim, a elaboração de um atlas geográfico para escolares, voltado para os processos da construção dos saberes, não é uma ação simplista e neutra. 
Os atlas escolares, no geral, têm se adequado ao currículo do Ensino Fundamental e Médio relativos aos programas de Geografia. Entretanto, eles não devem tornar-se um produto do conhecimento técnico atrelado às influências políticas e de poder sobre os conhecimentos a serem selecionados e representados. Lembrando que a lógica da seletividade pauta-se numa intencionalidade.

Há muitas questões que deverão ser ponderadas. Por que estes conhecimentos e não outros? Por que este mapa é considerado importante e não outro? Quais interesses guiaram a seleção deste mapa ou daquele mapa em particular? Quais são as relações de poder envolvidas no processo de seleção que resultou nesse atlas? Quais os referenciais teórico-metodológicos que direcionam a representação do espaço geográfico nos atlas escolares? Como é feita a distribuição dos mapas em relação aos temas tratados? O uso de textos, glossários, ilustrações (fotos, desenhos etc.) é fundamental? Qual a importância da visibilidade e legitimidade das informações cartográficas?

O objetivo maior de tais obras é a construção do conhecimento a partir do atlas e encaminhar o aluno para o estudo crítico da sua realidade próxima envolvida no todo mundial. Esse objetivo pode ser alcançado com um atlas que forneça uma informação precisa adequada à faixa etária escolar. Que convide o aluno a visualizar dados, a fazer a conexão entre esses dados e por fim, a transformá-los em conhecimento. Que funcione como um instrumento didático na prática pedagógica intencional do professor, e no seu papel de mediador com vistas ao aluno desenvolver habilidades de leitura da existência, extensão e configuração de conjuntos espaciais expostos, de dados qualitativos, ordenados e quantitativos nos mapas adaptados para o uso escolar.

\subsection{Os Atlas escolares para o conhecimento local}

Em geografia, o conceito de lugar não se limita apenas à sua localização geográfica, mas abarca também as percepções e vivências daqueles que 
compartilham do mesmo espaço e, consequentemente, Ihe atribuem determinados valores e significados. Conforme consta nos PCNs,

[...] o lugar é onde estão as referências pessoais e o sistema de valores que direcionam as diferentes formas de perceber e constituir a paisagem e 0 espaço geográfico. É por intermediário dos lugares que se dá a comunicação entre homem e mundo. (PCNs - Geografia-Terceiro e quarto ciclos do Ensino Fundamental. Brasília, DF:MEC, 198 . p.29)

Para Yu-Fu-Tuan (1980), o elo afetivo entre a pessoa e o lugar, em seu aspecto estritamente material, é dito topofilia. Esse sentimento se dá por ser o lar o lugar de recordações e o lugar de vida. Quando esse sentimento é bastante intenso resulta do fato do lugar ter sido um sítio de acontecimento emocionalmente forte ou de ter sido percebido como símbolo. Também deve ser acrescentada a atração estética ou da beleza do cenário. $\mathrm{O}$ apego que se tem ao lugar também é marcante.

A consciência de um passado vivido em certo local também é componente de peso no amor ao lugar. Acaba-se tendo uma atitude de lealdade para com o espaço de vivência.

O que pode mostrar bem este sentimento com o lugar é a expressão feita por Horácio (65 - 8 a.C.):

\footnotetext{
"Esta era uma das minhas orações: um pequeno pedaço de terra com jardim, perto de casa, uma fonte de água corrente e ao lado, um pequeno bosque. O céu me concedeu isto e muito mais do que eu esperava. É bom. O único que peço agora... é: que isto seja meu para sempre".
}

Ainda com respeito ao lugar comparece o bairro que, de acordo com o planejamento da cidade pode não ter significado como uma realidade para os habitantes locais. Os sentimentos que definem o bairro podem ser muito complexos e variam de pessoa para pessoa ou entre os grupos de pessoas que moram muito próximas. Os residentes de um bairro não têm a ideia da real extensão e particularidade de sua área a não ser que venham a conhecer áreas vizinhas limítrofes; mas ao conhecer estas e se envolverem com este mundo exterior, o seu bairro vai perdendo cada vez mais o significado que the era dado. 
ALMEIDA (2002, p.12), por sua vez aponta que

[...] o lugar emerge, então, como importante categoria de análise da Geografia, e também de outras áreas ligadas a estudos sócio-ambientais. Como consequência, os estudos locais ganham importância nas atividades escolares. (ALMEIDA, R., 2001, p.12)

Assim, no contexto das atividades escolares, para que o professor realize satisfatoriamente a mediação do conhecimento acerca do lugar com seus alunos, de forma condizente com o currículo, este necessita dispor de material didático adequado para este fim. Dentre estes materiais didáticos, pode se considerar os mapas e os mesmos reunidos em atlas.

No entanto, como destaca ALMEIDA (2002), os recursos que o professor encontra normalmente se limitam a plantas urbanas, informes, relatórios e planilhas que, pela sua própria natureza, são inadequados para a utilização escolar. Apesar de alguns municípios disporem de atlas escolares próprios, ainda existe uma grande demanda por materiais didáticos sobre o espaço local.

Os atlas escolares para o conhecimento local devem ser antes de tudo, fundamentados em bases teórico-metodológicas consistentes. Estas se voltariam para a construção e representação do espaço na criança e a representação de sua realidade espacial no ensino de geografia dos Anos Iniciais, para os problemas da cartografia escolar e para as orientações curriculares atuais, sem deixar de lado a adequação do material aos usuários e o uso das novas tecnologias a serviço da cartografia.

Assim, um atlas para o conhecimento do lugar, este geralmente associado ao município, apresenta-se como um recurso didático-pedagógico facilitador na formação qualitativa do sujeito neste processo. Possibilita ao professor desenvolver atividades significativas para o ensino de conceitos e conteúdos na Geografia, História e Ciências no Ensino Fundamental (OLIVEIRA e ALMEIDA, 2000).

Aproximar-se-ia, assim, o jovem do valor da preservação dos recursos naturais, da recuperação da memória e da história local e da percepção da sociedade que ao ocupar um espaço, modifica-o e nesse processo acaba por transformar a natureza e a própria sociedade. 
Há demanda no ambiente escolar de materiais didáticos sobre o lugar, seja em função da mudança nas relações "local-global", seja pelo destaque das questões sócio-ambientais do "local e global". O fato é que o entendimento, a concepção deste contexto, imediato e próximo é uma necessidade do ser humano, do ser cidadão. Visto que o conhecimento empírico com vistas a uma análise integradora: do particular para o universal e vice-versa, favorece 0 desenvolvimento metacognitivo dos alunos e o aperfeiçoamento e valorização do trabalho do professor pesquisador em sala de aula.

Para a Cartografia Escolar, o estudo do lugar em Geografia é de elevado significado na concepção de um atlas escolar local. Pois,

[...] o lugar como categoria de análise geográfica passa a tomar importância com a globalização, com as transformações recentes do mundo, provocadas pela técnica. O lugar ganha, então, outro sentido, como espaço do cotidiano, no qual as relações próximas, as tarefas corriqueiras permitem a construção da identidade (ALMEIDA, 2001, p.14)

Assim, o estudo do lugar é significativo para a construção de conceitos que busquem explicar a realidade a partir de uma realidade vivida e observada de uma forma crítica.

Seja por uma questão de tradição ou facilidade, o estudo do lugar na geografia escolar é quase sempre feito via atividades de tal contexto (textos, mapas, gráficos, figuras, fotos, imagens, etc.) que retratam um "local padrão", isto é, um modelo representativo de qualquer ponto do país ou fictício. A adequação desse lugar "padrão ou fictício" à realidade do aluno fica a cargo do professor que pode estar preparado para tal simulação ou não! O problema surge se o professor diante desse desafio, sentir-se desprovido de conhecimento, recurso didático e prática acerca da representação do espaço e do ensino de conceitos sócio-espaciais. Então, ter-se-iam algumas questões a respeito da formação e prática do professor pesquisador, do seu material didático e das condições sobre as quais ele é empregado.

A formação e a prática do professor pesquisador de geografia e o uso de recursos didáticos, no caso, um atlas escolar bem elaborado, aparece como um 
aliado eficiente do professor para o seu trabalho com mapas em sala de aula. Entretanto, a sua eficiência, não garante por si só, que a informação contida nele, resultará em conhecimento para o seu usuário, seja para o professor, seja para o aluno, lembrando que ambos são usuários distintos, porém, complementares. Daí, a necessidade de trabalhar as condições sobre as quais o produto é ou será usado.

Assim, o estudo do lugar deve partir das necessidades da realidade do professor pesquisador, de seus alunos e do currículo. Já as lucubrações acerca de como melhorar a metodologia dos atlas escolares, devem passar pelo geógrafo, cartógrafo, educador (formação e prática) e currículo de Geografia (BRASIL, 1998).

Desta forma, um estudo, voltado para questões teórico-metodológicas relacionadas ao atlas escolar para o conhecimento do lugar, com ênfase na mediação entre o lugar e o mundo, dentro do processo da totalidade, poderá favorecer um diálogo rico. Este teria a possibilidade de promover a compreensão da realidade do mundo próximo com um olhar rumo ao global distante, entendendo que o lugar reproduz a ordem internacional. Assim, para o aluno, estudar o lugar para compreender o mundo, apoiando-se também nos atlas escolares, significaria uma possibilidade de construir, desconstruir e novamente reconstruir a sua identidade e reconhecer o seu pertencimento. Não há, também, como deixar de lado as questões teórico-metodológicas da Geografia, com vistas às preocupações que são colocadas pela educação. 
CAPÍTULO III

\section{PROPOSTA METODOLÓGICA PARA A ELABORAÇÃO DE ATLAS GEOGRÁFICOS ESCOLARES}




\section{CAPÍTULO III - PROPOSTA METODOLÓGICA PARA A ELABORAÇÃO DE ATLAS GEOGRÁFICOS ESCOLARES}

O encaminhamento de uma pesquisa referente a uma proposta metodologia para a elaboração de um atlas escolar é bastante amplo. Passa pelo currículo, formação e prática do professor, além de incluir conhecimentos de cartografia, educação e geografia. Em se tratando do caso específico de atlas municipais congregar-se-iam também saberes sobre história e ciências, estas últimas, particularmente junto aos estudos do ambiente.

Entende-se que para esta elaboração, devem ser seguidas determinadas diretrizes, que considerem as contribuições de autores de referência, que se apóiam em orientações basilares e que visem a organização do próprio conteúdo deste tipo de Atlas.

\subsection{As dimensões espaço e tempo da realidade}

O espaço é o lugar material da realidade onde se concretizam as possibilidades dos eventos. Seu estudo é desenvolvido por vários campos científicos. Na Geografia tem uma posição de destaque.

O espaço geográfico é entendido como a concorrência de sistemas de objetos e sistemas de ações mais as técnicas, o que vai apontar como o território é usado. Este uso percorre um caminho que se iniciando como meio natural passa, depois, pelo meio técnico, alcançando na atualidade o meio técnico científico-informacional, o espaço geográfico, exibindo-se como uma nova configuração do espaço e do tempo (SANTOS, 1994).

Porém, o espaço possui também seu componente psicológico, pois o espaço em que se vive é muito mais psicológico do que absoluto, onde as distâncias são percebidas em termos de custo, tempo e acessibilidade, dando-se, assim, maior destaque às dimensões sociais. 
Na elaboração de atlas para crianças será desejável que elas compreendam a ação dos grupos sociais no espaço e no tempo.

Assim, o espaço construído e organizado pela sociedade no transcorrer de sua história será uma temática a ser desenvolvida na escola, onde atlas criteriosamente organizados poderão ter uma participação efetiva (OLIVEIRA, 1978, PAGANELLI et al., 1993; SANTOS, 1994; SANTOS e SILVEIRA, 2001).

$\mathrm{Na}$ existência humana, o tempo e o espaço são suas duas dimensões básicas. A existência de qualquer coisa está num tempo e se dispõe em determinado espaço. Portanto, há constante mudança em tudo. Pode modificar a posição bem como se alterarem as características do que está no espaço e no tempo. (MUEHRCKE, 1981, 1983; GOMES, 1983).

No transcorrer do tempo nada se repete. Tudo muda. Onde há mudança há movimento.

O conceito de tempo linear veio com os seguidores de Newton ao considerar o movimento da matéria em linha reta, substituindo a percepção do tempo como cíclico característico do período medieval.

A atualidade se apresenta em toda sua dimensão espaço-temporal. Nesta realidade está presente a dinâmica social que é o espaço geográfico, estreitamente ligado à história da humanidade. A sociedade ao se modificar continuará elaborando novas maneiras de sobrevivência e novos espaços em consonância com as solicitações de sua existência.

A dimensão tempo junto à geografia pode ser vista sob dois enfoques: o tempo como sucessão e o tempo como simultaneidade. A sucessão se dá na ordem temporal, compondo o tempo histórico. A simultaneidade coordena espaços com uso diferenciado de tempo. Assim, cada ação se dá em seu tempo, porém a diversidade de ações acontece concomitantemente (SANTOS, 1982, 1994, 2001). 


\subsection{A proposta metodológica}

No empreendimento de uma metodologia para Atlas geográficos como está sendo almejado, considera-se como uma primeira etapa para a sua coordenação, o entrelaçamento integrado de duas orientações básicas: o ensino do mapa e o ensino pelo mapa, levando-se em conta que, tanto dentro, como fora de seus mapas, coexistem as duas dimensões básicas da realidade: o espaço e o tempo.

\subsubsection{O ensino DO mapa}

O ensino do mapa lastreia-se nas posturas teórico-metodológicas conjugando o espaço e o tempo:

. no espaço: - a construção e representação do espaço na criança;

- a representação da realidade espacial pela criança envolvendo práticas iniciais de cartografia, bem como o aprendizado de sua Linguagem.

. no tempo: - a construção e representação do tempo na criança;

- a representação da realidade temporal pela criança envolvendo práticas iniciais de cartografia, que inclui a dimensão tempo bem como 0 aprendizado da respectiva Linguagem para representações dinâmicas.

\subsubsection{A construção e representação do ESPAÇO na criança}

A construção da noção de espaço na criança inclui como ela percebe e representa o espaço. Processa-se desde o nascimento. Ocorre junto a outras construções mentais, se firmando com a própria inteligência. Acontece em evolução 
contínua, tanto no nível perceptivo como no nível representativo. Percorre um longo caminho que vem desde a ação até alcançar a operação.

Dessa maneira, a construção do espaço guarda coerência com o desenvolvimento mental da criança como um todo. Este se realiza por meio de uma sucessão de adaptações entre a pessoa e seu meio, evoluindo numa sequência de etapas. Constitui-se por dois procedimentos: a assimilação (o indivíduo age de forma ativa sobre o meio) e a acomodação (o sujeito se acomoda ao objeto permitindo-lhe enfrentar o meio em que está com a assimilação de novos elementos que se incorporam àqueles que já existiam) (OLIVEIRA, 1978).

No início, a aludida construção da noção de espaço associa-se a um espaço sensório-motor, que se constitui nos dois primeiros anos de vida, conjugado à percepção e à motricidade. Este espaço se firma com uma interação entre a criança e seu ambiente, fazendo com que ela se relacione a determinados objetos ou pessoas no espaço. Comparecem as relações espaciais topológicas, com destaque à mais simples delas, a de vizinhança (perto/longe).

Na sequência, a construção do espaço se torna representativa (7 - 8 anos). Isto quando aparece a imagem e o pensamento simbólico em consonância com o desenvolvimento da linguagem.

Entretanto, neste estágio, na representação, a criança não aciona as relações espaciais projetivas e euclidianas, muito embora ela já as tenha construído no contexto sensório-motor. O espaço representativo se realiza como uma reconstrução, não mais a partir de atividades sensório-motoras, mas sim a partir de intuições relacionadas ao espaço topológico. A criança reconstruiria o espaço por intermédio da ação representativa desempenhada sobre a ação perceptiva.

Por fim, dá-se a construção do espaço de forma operatória, agora em reelaborações sucessivas. O espaço operatório se inicia lastreado em estruturas operatórias concretas, para passar, depois para aquelas formais. 
Fica confirmado, assim que, para a construção da noção de espaço na criança, não basta operar apenas a percepção, sendo necessário avançar até a representação.

No início, a concepção do espaço na criança é topológica. Porém neste espaço, ela não consegue ainda situar objetos uns em relação aos outros. Só fica nas noções de perto/longe, junto/separado, antes/entre/depois, dentro/fora e de continuidade espacial (coordenando partes do espaço com o todo do mesmo).

Para que ela alcance estruturas espaciais mais completas será necessário considerar diferentes pontos de vista e, depois, as distâncias e os ângulos. Para conseguir esta coordenação deverá proceder à elaboração de dois sistemas de conjuntos distintos, mas complementares.

Um deles é o sistema de perspectivas, que lhe possibilitará dispor vários objetos levando em conta diferentes pontos de vista. Neste sistema a criança articulará as noções de à direita/à esquerda, frente/atrás, em cima/embaixo, primeiro em relação a ela própria (5 - 8 anos), depois em relação a outrem colocado à sua frente (8 - 11 anos) e por fim interligando vários pontos de vista.

A noção básica é de à direita e à esquerda, dadas pelo conhecimento da lateralidade, primeiro no próprio corpo da criança, depois em outros corpos, implicando ela ter consciência de ter mão direita e mão esquerda, reconhecendo-as. A lateralidade provém do processo de lateralização associado à assimetria funcional quando se verifica o predomínio de um lado do corpo. É necessário que o professor verifique este predomínio lateral, seja para o lado direito ou para o esquerdo. Confere-se se a criança é destra ou canhota. Lembra-se que, o fato dela ser canhota e contar com o predomínio do lado esquerdo, para ela é a mesma coisa de ser destra.

O outro sistema é aquele das coordenadas, base do espaço euclidiano. É um sistema de referência fixo que adota medidas de distância e de direções em relação a dois eixos ortogonais entre si, dando à criança a oportunidade de situar objetos uns em relação aos outros e mesmo deslocá-los no interior de um mesmo campo. 
O Professor Vinh-Bang numa entrevista concedida à Professora Lívia de Oliveira em 1976 the afirmara que a representação do espaço no caso daquele geográfico, que seria aquele que estaria no mapa, iniciar-se-ia pela percepção e representação das relações espaciais topológicas para depois passar àquelas projetivas e euclidianas (OLIVEIRA, 1978; PAGANELLI et al., 1993, ALMEIDA e PASSINI, 1989).

$\mathrm{Na}$ construção da noção de espaço foi visto, de acordo com a teoria psicogenética desenvolvida por Piaget e seus colaboradores, como as crianças estabelecem relações espaciais com a realidade em que vivem e como representam o espaço total no qual se movimentam.

Nessa representação entra em jogo a construção de sua realidade por meio do desenvolvimento do símbolo com base na imitação e no jogo e das relações que existem entre as pessoas, os objetos e aspectos da realidade no espaço (OLIVEIRA, 1978).

É marcante na representação do espaço pela criança o fato de que, enquanto a percepção e o conhecimento dos objetos que compõem a realidade exigem um contato direto com eles, a representação consiste em evocar tais objetos em sua ausência.

É, portanto, o momento que entra em cena nas significações da representação a relação entre o significante - o símbolo - (o que a criança desenha) e o significado do símbolo (o que a criança pensa) dos elementos que compõem o espaço (OLIVEIRA, 1978).

Será pertinente também que a criança compreenda que o desenho do contorno do seu corpo traçado por um colega ou professor no chão quando deitada de costas sobre o pavimento é a representação de seu corpo no espaço e não o seu corpo (PAGANELLI, et al., 1993). 


\subsubsection{A representação da realidade espacial pela criança}

Para a filosofia uma representação é um ente que se coloca para estar por outro ente. A representação está sempre por algo. Ela consiste em evocar algo em sua ausência. É uma construção que substitui algo, resultando de uma atividade.

Representação é toda criação social e/ou individual de um esquema apropriado do real. É importante reter que elas se imergem no social e num dado momento. Portanto, são dinâmicas (GUMUCHIAN, 1989).

$\mathrm{Na}$ atualidade é expressiva a abundância de representações. Constituem feitos sociais por excelência. Elas são produtos da mente humana.

Para Hegel, a representação é uma etapa, um momento do processo de conhecimento. Com esta consideração será possível defender a validade dos mapas no fazer geografia (LEFÉBVRE, 1981).

Já de há tempo, a alfabetização vem se colocando como uma incumbência a ser desenvolvida pelos educadores, porém apenas no campo do ensino e aprendizagem da leitura e escrita da linguagem escrita e falada de um idioma. Com o alvorecer de uma Cartografia escolar deu-se início a uma progressiva aplicação para o caso da leitura e escrita da linguagem gráfica dos mapas confirmando uma Alfabetização cartográfica.

Em épocas mais recentes vem surgindo o termo "Letramento cartográfico" por possuir uma dimensão mais ampla. Letramento vem do inglês: literacy. Letramento resulta da ação de ensinar e aprender a ler e escrever, propiciando à pessoa a apropriação da escrita. Assim, ela poderá cultivar práticas sociais que empregam a escrita. É neste sentido que se assistiu à confirmação de um Letramento cartográfico, mesmo que em certos momentos pode-se considerar uma alfabetização cartográfica (OLIVEIRA, 1978; CASTELLAR, 2011; SOARES, 2002). 
No aludido letramento cartográfico fazem-se presentes os conhecimentos da cartografia. Passa-se, assim, a proceder a lucubrações e elaborações neste campo científico.

Dando início à representação da realidade espacial pela criança estar-se-á entrevendo a possibilidade de se trabalhar, como preâmbulo à elaboração do mapa, com a construção do símbolo e organização da legenda.

Como se trata de uma representação em mapa deve-se ter claro que ela resulta de uma visão vertical, de cima para baixo, de determinado espaço com todos os seus elementos. Os símbolos que vão compô-la também serão apresentados em visão vertical.

Portanto, para se iniciar a construção do símbolo deve-se ter certa noção da visão vertical, a qual geralmente não é suficientemente experimentada por ser incomum. Porém, será fácil fazer com que as crianças experimentem estas visões e até tirem fotos. Basta olhar para um balde, por exemplo, primeiro numa visão frontal, ficando bem de frente e no mesmo nível onde está o objeto, depois numa visão oblíqua, tomando posição de olhá-lo, situando-se em uma posição pouco acima dele e, por fim, observá-lo colocando-se numa disposição bem acima do balde, olhando-o na vertical, de cima para baixo. As fotos registram estas três visões do objeto escolhido. A última tomada é a que servirá de base para construir o símbolo.

Para se passar à atividade de construir símbolos de elementos de uma paisagem, primeiro desenham-se esses objetos como vistos de frente na realidade. Depois, desenham-se os imaginando como se fossem vistos de cima. Finalmente, como o mapa é uma visão de cima, simplificam-se os desenhos feitos tornando-os símbolos.

Os símbolos poderão assumir formato de ponto, linha ou área conforme os objetos referentes se manifestam em ponto, linha ou área na realidade a ser representada. Assim, uma árvore será representada por um pequeno círculo verde 
(como se fosse sua copa vista de cima). Uma estrada seria uma linha vermelha e uma área de pastagem seria um quadradinho colorido de verde.

Outra forma de iniciar as crianças na construção de símbolos é a que as leva a elaborar aqueles icônicos, derivados diretamente dos objetos referentes, guardando grande analogia com estes. Assim, o símbolo para floresta seria um desenho simplificado de duas ou três árvores juntas.

Elaborados os símbolos eles serão organizados no mapa em um campo específico que toma o nome de legenda. A legenda é o local onde se elencam os símbolos do mapa, tendo ao lado deles, expostos os respectivos significados. Demonstra a relação entre o significante do símbolo e o significado do mesmo. Ao consultar na legenda determinado símbolo, tem-se imediatamente o significado do mesmo pela leitura de sua descrição.

Neste contexto inicia-se também a exploração das relações espaciais, agora no plano representativo, para a localização da própria criança, de pessoas e de objetos no espaço que poderão vir a fazer parte de representações em mapas.

As primeiras relações espaciais a serem elaboradas são as topológicas. Nelas a localização no espaço de pessoas e objetos não vai considerar direções nem distâncias. Portanto, nas crianças, elas se operarão em termos de vizinhança (perto/longe), de separação (junto/separado), de ordem (antes/entre/depois), de inclusão (dentro/fora) e de continuidade espacial (coordenando partes do espaço com o todo do mesmo).

Ao designar a localização de pessoas e objetos no espaço em termos de em cima/embaixo, na frente/atrás, à direita/à esquerda, a criança estará mobilizando as relações espaciais projetivas, que variam de acordo com o ponto de vista assumido pela criança ou com os referenciais específicos tomados.

No início, o ponto de referência é a própria pessoa. Desloca-se em seguida para outras pessoas e objetos, quando a criança passa a adquirir a capacidade de situar uns em relação aos outros. 
Lembra-se aqui, de confirmar o predomínio de um lado do corpo na criança o processo de lateralização, que leva ao conhecimento da lateralidade, isto é o fato dela reconhecer os lados direito e esquerdo do corpo.

As relações espaciais projetivas se desenvolvem em três etapas:

- à direita/à esquerda, frente/atrás, acima/abaixo em relação a si próprio (dos 5 aos 8 anos);

- à direita/à esquerda, frente/atrás, acima/abaixo em relação a alguém colocado à sua frente (dos 8 aos 11 anos);

- coordenando vários pontos de vista, ficando a criança bastante liberta de seu egocentrismo.

Superadas estas três etapas para a localização de si, de outras pessoas e de objetos e pessoas no espaço, a criança estará preparada, agora, para assimilar a noção de orientação, entendendo as direções cardeais na rosa dos ventos para se orientar e se localizar. Porém, elas devem estar apoiadas na experiência obtida com a observação do movimento aparente do Sol durante o dia. Este movimento se observa de Leste para Oeste. Assim, a trajetória do Sol fornece a direção LesteOeste. A direção Norte-Sul é perpendicular a esta. Os próprios alunos podem comprová-la, fincando uma estaca no solo e verificar que, quando o Sol estiver em seu ponto mais alto, lá por volta do meio-dia, a sombra da estaca será mais curta. E se projetará do lado que indicará sobre a direção Norte-Sul o sentido para o Sul, isto válido para o hemisfério Sul, O oposto a ela será o sentido para o Norte.

Por fim, as crianças passam a realizar relações espaciais euclidianas, localizando a si, objetos ou pessoas em relação a um sistema de referência fixo, segundo as duas dimensões do plano, adotando medidas de distância (PAGANELLI et al., 1993).

Passa-se, agora para a localização na superfície da Terra, que será transferida para o mapa, o que exige uma elaboração mais complexa baseada nas relações espaciais projetivas associadas às euclidianas: as coordenadas 
geográficas, formalizando a longitude e a latitude de cada lugar no globo e no mapa, a partir de um sistema articulado a um par de linhas que se cruzam ortogonalmente num ponto: um meridiano e um paralelo, origens do sistema, quais sejam, o Meridiano de Greenwich ( $\left.0^{\circ}\right)$ e o Equador ( $\left.0^{\circ}\right)$.

Este é o ponto de chegada da construção do espaço. Os alunos, agora, serão capazes de orientarem-se e localizarem-se usando referências abstratas, como aquelas dos mapas, atividades essenciais para sua própria organização espacial, junto à sociedade hodierna.

Seguem-se considerações sobre a escala. Como se trata de alocar a realidade espacial em uma folha de papel, no caso da elaboração de mapas no sistema analógico, é necessário mobilizar o raciocínio que envolve as operações de redução proporcional.

É bom lembrar que, quando se propõe refletir sobre geografia e suas representações em mapas surgem duas noções de escalas: a escala geográfica e a escala cartográfica.

A Escala Geográfica permeia o entendimento do espaço geográfico enquanto um sistema indissociável de objetos e sistema de ações, em suas dimensões local, regional-nacional e global e respectivas interconexões destes. Ela busca não se ater apenas à precisão da localização e do desenho da forma, mas, o seu objetivo maior é a procura pelo conteúdo de um recorte do espaço geográfico que pode ser representado em um mapa sem fragmentar a sua totalidade, pois está diretamente associada à ideia de totalidade-mundo (SANTOS, 1997).

Sob o ponto de vista conceitual de ampliação e redução, tem-se a escala cartográfica que busca referência significativa como a relação matemática entre as dimensões de um objeto na realidade e as do desenho que o representa em um mapa.

Entretanto, Castro (2000), por sua vez, advoga que a escala cartográfica, por si só, não se mostra mais eficaz para ajudar no entendimento da complexidade do espaço geográfico. 
Se "forma, tamanho e desenho" constituem atributos de uma geometria do espaço, para a geografia, "tempo e forma" são dados do processo, portanto, são elementos essenciais para a elaboração de um conceito de escala geográfica que dê conta do período atual. A autora lembra, ainda, que o tempo define e redefine a forma, a função e o limite e que o movimento dos eventos cria e recria formas materiais e o resultado disso tudo é um contínuo processo de fazer e refazer de formas, conteúdos e limites. Trata-se de um desafio, pois segundo a citada autora, "tão importante como saber que as coisas mudam com o tamanho, é saber exatamente o que muda e como" (CASTRO, 2000).

Assim, estar em um lugar, exige estabelecer relações deste lugar com outros lugares mais longínquos e em outros momentos, isto é, estabelecer relações com as diferentes escalas espaço-temporais. Fenômenos sociais se dão em tempos curtos e em espaços exíguos, necessitando escalas grandes para representá-los em mapas. Fenômenos naturais, excluindo-se as catástrofes, em geral se dão em tempos longos e em espaços enormes, necessitando de escalas pequenas para representálos.

É certo que não se pode mais trabalhar a Geografia, em sala de aula, servindo-se de seus mapas com suas escalas, apenas no sentido de maior ou menor proximidade entre as cidades, estados, países. Pois, estar-se-ia meramente reproduzindo apenas o espaço absoluto em detrimento do espaço geográfico e do entendimento do mesmo. Entretanto, ao se abandonar o espaço absoluto - o euclidiano - ter-se-ia que entrar em outras concepções de espaço, onde autores, desde a década de 1950 pesquisam a questão.

A noção de escala junto às crianças deve, primeiramente, ser trabalhada de forma qualitativa: a foto de uma jovem em visão frontal, de perto, enquadrando apenas o rosto fornece uma imagem de detalhe, portanto, uma representação em escala grande. A foto da mesma pessoa também em visão frontal, porém, tomada à distância, focalizando o corpo inteiro, apresenta uma imagem de conjunto, certamente com perda dos detalhes, portanto, uma representação em escala pequena. Depois, a escala precisa ser apresentada em sua proporção métrica. É necessário ter aprendido frações e sistema métrico decimal, hoje denominado de Sistema Internacional de Unidades (SI), junto à matemática. 
O mesmo raciocínio é transposto para a visão vertical, aquela dos mapas, tomada do avião para a escala grande e captada por satélite para a escala pequena. No mesmo campo, a foto aérea registra, em detalhes, os aspectos do terreno, enquanto que a imagem de satélite mostra uma grande porção da superfície da Terra. No primeiro caso tem-se uma planta em escala grande (1: 10.000) e no segundo, obtém-se um mapa em escala pequena (1: 1.000.000).

Nesse ponto caminhar-se-ia para uma questão bastante complexa e intrigante. É aquela atinente à compreensão da passagem da superfície da Terra, que é aproximadamente esférica, para aquela do mapa, que é plana. Esta operação é feita pela projecão, envolvendo sempre deformações, como quando se tenta tornar plana sobre a mesa uma casca de mexerica. Isto é realizado com o auxílio das superfícies de projeção que podem ser o cilindro envolvente, o cone envolvente e o plano tangente. Destas, quando desenvolvidas e estendidas no plano, resultam respectivamente, a projeção cilíndrica, a projeção cônica e a projeção plana.

Próximo ao campo das projeções pode-se considerar o domínio das Transformações cartográficas, pois já de há tempo comparecem nos livros e atlas geográficos escolares. Resultam das contribuições trazidas à cartografia pelos avanços da ciência da computação, da informática aliadas às tecnologias do presente. Elas se centralizam na valorização dos padrões espaciais que os atributos ou variáveis constroem, atentando mais para o respectivo aspecto morfológico, em vez de ficarem apenas presas às constatações das distribuições geográficas (RIMBERT, 1990).

Não seria uma grande novidade ao se considerar que Hägerstrand, na década de 1950 ressaltou em mapa como as pessoas residentes em Asby, Suécia, percebiam o espaço ao seu redor, exagerando e enaltecendo a importância das áreas mais próximas em detrimento das mais afastadas. Para esta representação, empregou uma Projeção Azimutal na Escala Logarítmica (HÄGERSTRAND, 1957).

São transformações cartográficas os Cartogramas e as Anamorfoses. Os Cartogramas são representações onde prevalece o tema, sendo elaborados 
justapondo-se sucessivamente as unidades de observação contíguas que, ao mesmo tempo em que perdem as formas e áreas originais, passam a ficar de tamanhos proporcionais à variável selecionada, com formato, em geral, quadrangular. As Anamorfoses são elaboradas a partir de uma superfície uniforme que, graças a operações matemáticas, sofreria dilatações ou contrações de forma contínua, por conta de uma força, em função de um maior ou menor valor da variável considerada (RIMBERT, 1990).

BRASIL: POPULAÇÃO - 2000

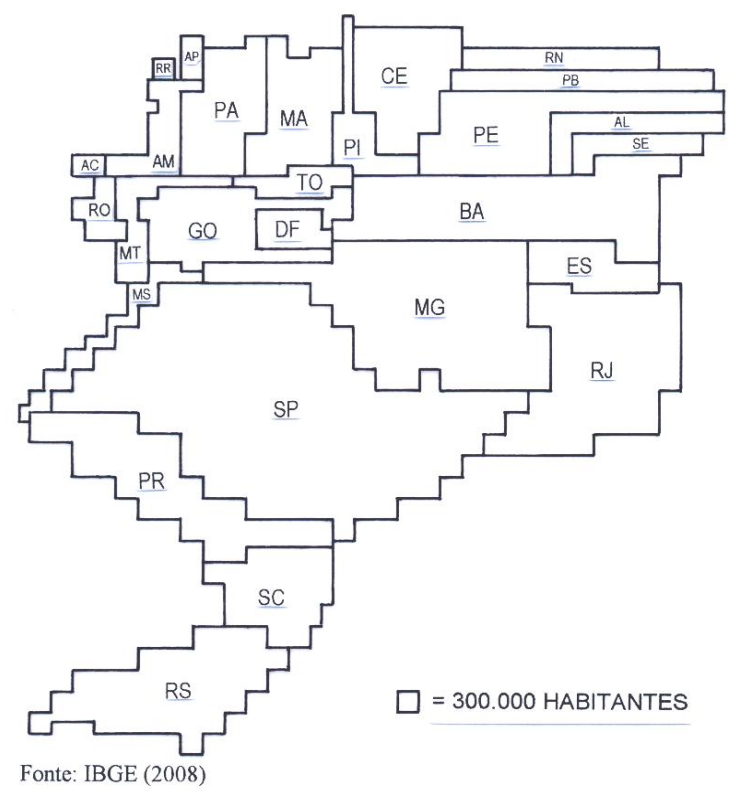

Figura 3 - Cartograma da população do Brasil 2000. Fonte: MARTINELLI (2011: 131).
BRASIL: PRODUTO INTERNO BRUTO - 2000

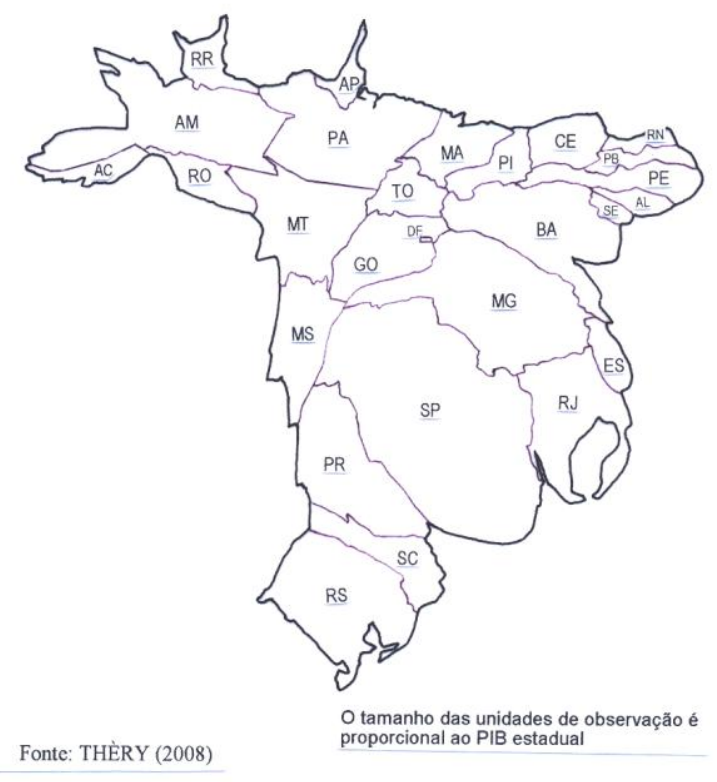

Figura 4 - Anamorfose da população do Brasil 2000.Fonte: MARTINELLI (2011: 130).

Tais representações como transformações cartográficas constituem ainda um assunto complexo no âmbito do ensino e aprendizagem da geografia com mapas, merecendo estudos específicos. Está certo que hoje elas são muito enaltecidas e difundidas na internet. Entretanto, acredita-se que uma criança teria dificuldades de trabalhar com essas representações. Seria muito difícil o escolar fazer a transposição do espaço euclidiano, o qual the é mais familiar, para essas novas "deformações" ou vice-versa, que o alteram em benefício de comunicar outras "relações" mais sensíveis e gritantes para quem já tem prática nessas novas leituras.

Elas já aparecem nos atlas, complementando a estrutura temática estipulada. Um atenuante que poderia trazer alguma contribuição à leitura, análise e interpretação destes mapas seria colocar junto ao cartograma ou anamorfose um 
mapa cartográfico dispondo a base das unidades espaciais de apoio para a representação dos dados. Porém, numa projeção já bem assimilada pelos pequenos leitores com todas elas na mesma cor, apenas para servir de referência para as crianças reconhecerem os territórios que estão expostos na representação.

Tal como está acontecendo no presente com os Cartogramas e as Anamorfoses, na década de 1980 ter-se-ia levado para o ensino fundamental e médio uma novidade, uma prática diferente, um novo alfabeto da geografia, com os modelos gráficos.

Foi uma época em que se afirmaram os modelos provindos da Teoria Geral dos Sistemas de Bertalanffy elaborada em 1937, como capazes de explicar a realidade junto aos mais variados ramos científicos (BERTALANFFY, 1968).

Em termos de modelos gráficos na Geografia foi Brunet (1980; 1987) que dispôs as bases para tanto. Estabeleceu uma gramática dos Coremas. Coremas são estruturas elementares de organização do espaço, cuja combinação cria modelos intermediários, que combinados neste passo medianeiro elaboram como produto final o mapa modelo. Será um modelo gráfico explicativo de uma realidade geográfica.

Com a obra Cartes et modèles à l'école de 1987, seus autores estabeleceram encaminhamentos para uma possível utilização dos modelos gráficos no ensino da geografia nos níveis fundamental e médio da França, após experiências pertinentes em sala de aula (CLARY, M. et al., 1987).

Concluída esta parte básica, ingressar-se-ia, agora, num momento, que será oportuno para as crianças empreenderem mediante a linguagem da cartografia a representação gráfica da realidade, onde se expressarão graficamente as relações espaciais e de conteúdo entre os componentes da realidade que vivenciam ou que venham a conhecer por meios de comunicação.

Dentro da Cartografia, será o campo da Cartografia Temática, que é um setor especializado em elaborar mapas com temas históricos, geográficos e ambientais que os Atlas escolares requer, a propiciar os meios para tanto. 
Neste campo trabalhar-se-á com a citada linguagem da cartografia, tendo por fundamento, junto ao leque de paradigmas oferecidos pela cartografia, mormente durante o século XX, as posturas tomadas por Bertin (1973), que a denomina linguagem da representação gráfica, como já foi apresentado no item 1.3. Serão retomados aqui detalhes específicos direcionados à elaboração dos mapas dos atlas.

É preciso, aqui, esclarecer que acima foi ressaltada a proposta da linguagem da representação gráfica apenas para os mapas por se estar tratando especificamente deles junto aos atlas. Entretanto, a mesma linguagem inclui a elaboração dos gráficos e das redes, que como será apresentado mais adiante, também poderão compor complementarmente os atlas

Acrescenta-se, ainda, que ao adotar tal postura estar-se-á mobilizando uma estrutura específica: o sistema semiológico monossêmico ${ }^{10}$. Ficando para as fotos, desenhos, pinturas, grafismos e gravuras, que são bem vindas ao fazem parte do universo dos atlas, o sistema semiológico polissêmico ${ }^{11}$.

Como ponto de partida, frisa-se mais uma vez que tal postura estabelece que a representação de um tema deva estar atenta a transcrever graficamente as relações de diversidade, ordem e proporcionalidade entre objetos, fatos ou fenômenos geográficos observados que compõem a realidade espacial a ser abordada, por relações visuais de mesma natureza.

Assim, a relação de diversidade será transcrita por uma diversidade visual, a relação de ordem, por uma ordem visual e a de proporcionalidade por uma proporcionalidade visual. Saber coordenar tais orientações significa dominar com destreza a sintaxe desta linguagem (BERTIN, 1973, 1977).

\footnotetext{
${ }^{10} \mathrm{O}$ sistema semiológico monossêmico pertence ao domínio das operações mentais lógicas, pois não dá margem a ambigüidades, como por exemplo, uma equação matemática.

${ }^{11}$ No sistema semiológico polissêmico há maior abertura para ambiguidades (significados múltiplos). Exemplo: fotografia, pintura etc.
} 


\begin{tabular}{|c|c|c|c|c|}
\hline \multicolumn{3}{|c|}{ Relações entre objetos } & Conceitos & Transcrição gráfica \\
\hline Caderno & Lápis & Borracha & $\stackrel{F}{\mathbf{F}}$ & \\
\hline $\begin{array}{l}\text { Medalha } \\
\text { de ouro }\end{array}$ & $\begin{array}{l}\text { Medalha } \\
\text { de prata }\end{array}$ & $\begin{array}{l}\text { Medalha } \\
\text { de bronze }\end{array}$ & $\underset{\text { Ordem }}{0}$ & \\
\hline $\begin{array}{c}1 \mathrm{~kg} \\
\text { de arroz }\end{array}$ & $\begin{array}{c}4 \mathrm{~kg} \\
\text { de arroz }\end{array}$ & $\begin{array}{c}16 \mathrm{~kg} \\
\text { de arroz }\end{array}$ & $\underset{\text { Proporcionalidade }}{\text { Pand }}$ & \\
\hline
\end{tabular}

Figura 5 - A transcrição gráfica das relações entre objetos. Fonte: Martinelli (2012)

Dentro desse entendimento, têm-se ainda dois componentes básicos: as variáveis visuais compostas pelas duas dimensões do plano (que definem a posição de cada elemento visível do plano) e mais quatro modulações visuais consideradas como as principais (tamanho valor, cor e forma), com suas respectivas propriedades perceptivas. Deve-se dizer ainda que as duas dimensões do plano, o tamanho e o valor constituem as variáveis da imagem, a cor e a forma se comportam como variáveis de separação dos elementos que compõem a imagem ${ }^{12}$.

\section{AS VARIÁVEIS VISUAIS}

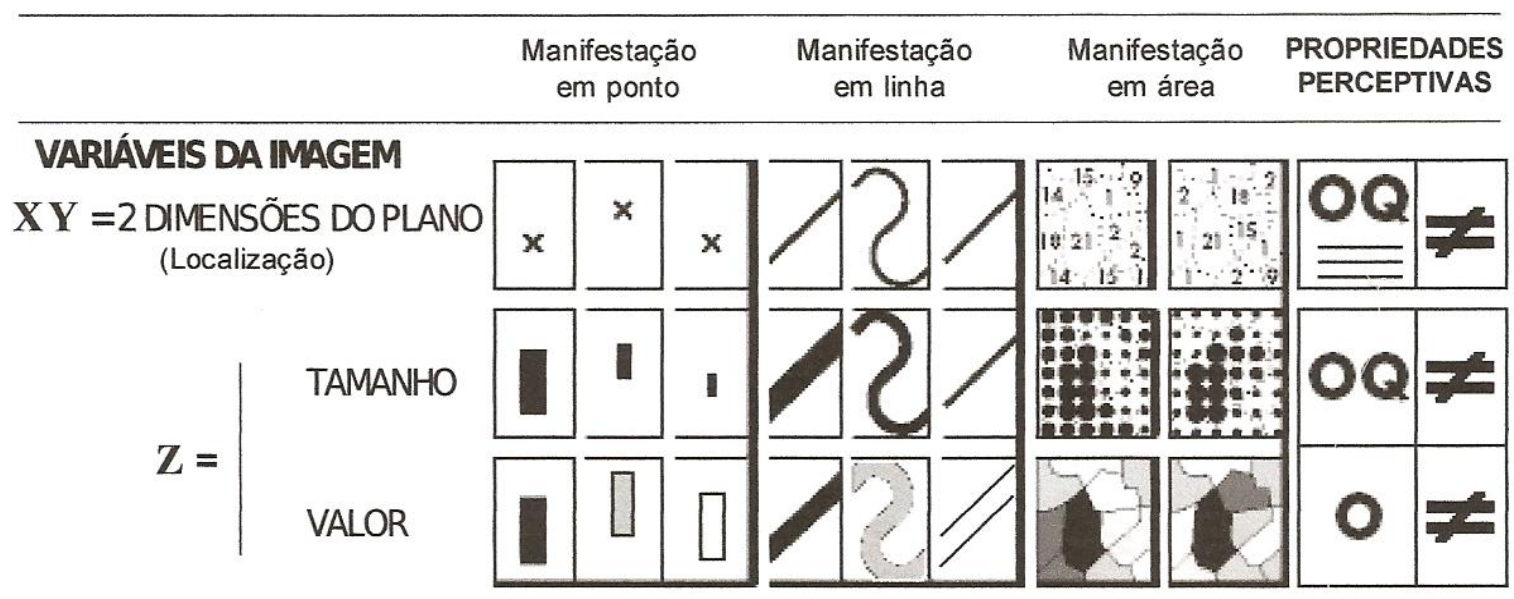

VARIÁVEIS DE SEPARAÇÃO $\mathbf{Z}=\mid \begin{aligned} & \text { COR } \\ & \text { FORMA }\end{aligned}$
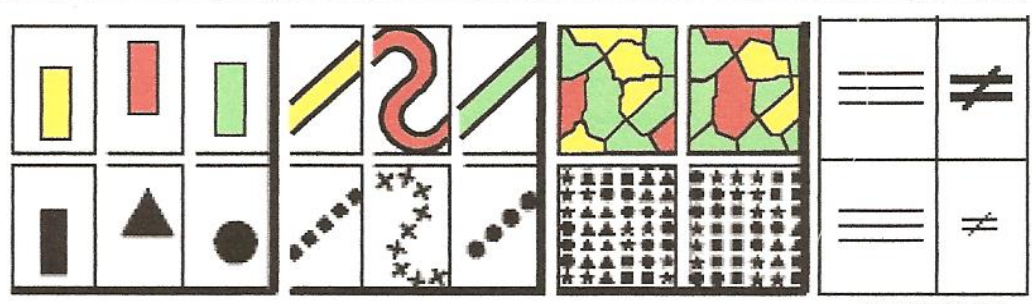

BERTIN (1977)

Figura 6 - As principais variáveis visuais da imagem e de separação

\footnotetext{
${ }^{12}$ Na proposta completa de BERTIN (1973) as variáveis visuais são seis: tamanho, valor, cor, forma, orientação e granulação.
} 
Junto à proposta de BERTIN (1973) para as bases da gramática da linguagem da representação gráfica, como também frente a outras tantas desenvolvidas principalmente no século $X X$, configuram-se as contribuições, que vieram desde o Terceiro Congresso Internacional de Estatística realizado em Viena, em 1857, no qual se estabeleceu uma primeira classificação dos métodos de representação que surgiram até então.

Com tais contribuições pode-se assumir um encaminhamento de orientação metodológica para representações da realidade em mapas com uma estrutura lastreada na seguinte atitude: os mapas temáticos podem ser elaborados levando-se em conta vários métodos; cada um mais apropriado às características e às formas de manifestação (em pontos, em linhas, em áreas) dos fenômenos da realidade considerados em cada tema seja na abordagem qualitativa, ordenada ou quantitativa.

É possível empreender também uma apreciação sob o ponto de vista estático, constituindo a cartografia estática, ou dinâmica, estruturando a cartografia dinâmica, onde se faz presente a dimensão tempo. Deve-se salientar, ainda, que os fenômenos que compõem a realidade a ser representada em mapa permitem ser vislumbrados dentro de um raciocínio analítico ou de síntese.

Neste sentido ter-se-ia de um lado uma cartografia analítica - abordagem dos temas em mapas analíticos, atentando para seus elementos constitutivos, lugares, caminhos ou áreas caracterizadas por atributos ou variáveis, mesmo que cheguem à exaustão, através de justaposições ou superposições. E, de outro, uma cartografia de síntese - abordagem temática em mapas de síntese, tendo em vista a fusão dos seus elementos constitutivos em "tipos", que seriam agrupamentos de lugares, caminhos ou áreas de análise caracterizadas por agrupamentos de atributos ou variáveis (RIMBERT, 1968; CUENIN, 1972; MARTINELLI, 2011).

Para a elaboração dos mapas temáticos junto aos Atlas escolares, podese considerar esta estrutura metodológica: 


\section{Formas de manifestação dos fenômenos:}

- em ponto;

- em linha;

- em área.

\section{Apreciação e abordagem dos fenômenos com seus métodos de representação:}

- apreciação estática:

- representações qualitativas (método dos pontos diferenciados, método das linhas diferenciadas e método corocromático qualitativo); - representações ordenadas (método dos pontos ordenados, método das linhas ordenadas e método corocromático ordenado);

- representações quantitativas (método das figuras geométricas proporcionais, método dos pontos de contagem, método coroplético e método isarítmico);

- apreciação dinâmica:

- representações das transformações de estados e das variações quantitativas absolutas e relativas no tempo (método corocromático qualitativo, método corocromático ordenado, método das figuras geométricas proporcionais e método coroplético);

- representações dos movimentos no espaço (método dos fluxos).

\section{Nível de raciocínio:}

- representações analíticas: representação dos elementos constitutivos lugares, caminho ou áreas caracterizadas por atributos ou variáveis (qualitativos, ordenados, quantitativos);

- representações de síntese: representação da fusão dos elementos constitutivos em "tipos" - agrupamentos de lugares, caminhos ou áreas unitárias de análise caracterizadas por agrupamentos de atributos ou variáveis (qualitativos, ordenados, quantitativos).

Por fim, depois de prontos, os mapas podem propiciar dois níveis de apreensão. 


\section{Nível de apreensão:}

- mapa exaustivo: todos os atributos ou variáveis sobre o mesmo mapa leitura, análise e interpretação em nível elementar (só responde à questão "O que há em tal lugar?");

- coleção de mapas: um mapa por atributo ou variável - visão de conjunto (responde a todas as questões, inclusive a "Onde está tal atributo ou variável?" ou "Quais agrupamentos se formaram?") (MARTINELLI, 2011, p. 43).

Como já adiantado, a par de todas as possibilidades de representações em mapas é preciso mencionar que, paralelamente coexistem representações em gráficos de vários tipos, que conforme as orientações dirigidas à elaboração dos atlas podem estar presentes. Os gráficos evolutivos de linhas e de colunas são os mais requisitados para acrescentar, complementarmente aos mapas estáticos, aspectos dinâmicos de determinada realidade em foco.

Também como já anunciado, com demanda muito específica, também podem comparecer nos atlas, as redes. São construções gráficas que exploram sobre o plano bidimensional $(X, Y)$ as correspondências entre todos os dados de um mesmo componente da informação: as relações de parentesco entre indivíduos de uma mesma família. A Linha do tempo é uma elaboração que obedece a estas orientações. Comparece junto à História quando se deseja concatenar ao longo do tempo eventos que marcaram transformações e evoluções de uma sociedade no tempo e no espaço.

\subsubsection{A construção e representação do TEMPO na criança}

A construção e representação do tempo na criança incluem como ela o percebe e o representa. Não é simples. Ficará mais fácil quando for associada a 
uma experiência concreta que já tenha vivido outras vezes. A compreensão do tempo deverá ser feita em suas várias dimensões, como já especificado: o tempo físico e o tempo histórico.

O tempo físico é aquele que permite a criança perceber o passar do tempo e saber fazer sua quantificação e representação.

O tempo histórico, por sua vez, é aquele que vai iniciar a criança no entendimento do seu tempo como sendo diferente dos outros tempos e que o tempo resulta da construção social.

Sendo o tempo um conceito muito abstrato, será construído na criança em três etapas marcantes:

- tempo sensório-motor: é a fase de um tempo prático ligado às ações. É o tempo da ação. Só existe como tempo de duração de determinada ação.

- tempo intuitivo: neste estágio as intuições temporais se ligam ao egocentrismo. Depois vai acontecendo uma descentralização. Será quando cada movimento tem um tempo particular, porém não existindo ainda a relação entre movimentos sucessivos.

- tempo operatório: é quando se constrói um tempo único que inclui todos os momentos. Confirmam-se as noções de sucessão, de duração e de simultaneidade, tidas como relações temporais, de onde resulta a continuidade do tempo, todas passíveis de contar com uma representação.

Sucessão. Esta noção se vincula ao domínio da relação antes/depois. É a atividade de colocar os fatos vivenciados no espaço numa sucessão temporal, identificando o que ocorreu antes e o que ocorreu depois. Como a ordem dos acontecimentos que se dão num espaço é irreversível passa-se a compreender o tempo.

Duração. É o intervalo de tempo que transcorre entre o início e o fim de uma ação. Entra em jogo o que se pode fazer durante certo período. Esta noção é uma preparação para o entendimento dos três níveis do tempo histórico: tempo curto - 
representado por um acontecimento. Tempo médio - representado pela situação econômica, social, política, cultural em certo período. Tempo longo - representado por um tipo de sistema, como é o caso do sistema capitalista. Os três se manifestando também na dimensão espacial.

Simultaneidade. Implica na correspondência que se dá entre dois movimentos que acontecem na mesma duração. Na passagem de um liquido de um recipiente para outro se coordenam dois movimentos: retirar de um e passar para o outro, que são realizados num mesmo intervalo de tempo em que dura essa passagem.

Dá-se, assim, início à apreensão da historia da vida da criança, passando depois para a história do bairro, do município e de outros níveis escalares correlatos de espaços, para que ela possa perceber que no mesmo intervalo de tempo coexistem no próprio espaço, diferentes tempos históricos. A mesma terá que entender que o tempo é contínuo e passa sem cessar. Portanto, as representações terão que ser dinâmicas (PAGANELLI, 1985).

\subsubsection{A representação da realidade no TEMPO pela criança}

$\mathrm{Na}$ representação da realidade no tempo, que evidentemente possui também uma dimensão espacial, recorre-se às representações dinâmicas em mapas. A cartografia as disponibiliza.

Do ponto de vista metodológico, as representações dinâmicas constituem ainda hoje um desafio para a cartografia. Pode-se dizer que se trata de uma busca consciente em prol da sistematização de uma cartografia dinâmica.

Atualmente, o termo cartografia dinâmica refere-se especificamente à manipulação interativa da informação espacial, com a respectiva visualização, possível em tempo real, fruto dos grandes avanços tecnológicos, envolvendo a cartografia digital, o que certamente promoverá profundas mudanças na disciplina. 
Um dos grandes feitos no campo da tecnologia e da ciência da computação para dar mais vida às representações dinâmicas foi o advento da animação cartográfica. Tem um grande potencial ao revelar dinamismo dos fenômenos, detectando processos no tempo e espaço.

A tecnologia da realidade virtual foi outro grande acréscimo à possibilidade de novas representações dinâmicas, oferecendo promissoras perspectivas.

O voo virtual, da mesma maneira, pode contribuir à visualização de deslocamentos no espaço durante certo tempo com grande capacidade de imersão, em condições interativas.

É por conta destas potencialidades que tais representações deveriam ocupar posição de destaque na cartografia atual, alcançando os mapas que deverão fazer parte dos atlas escolares, pois o mundo de hoje, mais do que nunca, é essencialmente mutante. Há movimento.

Portanto, a cartografia deverá se interessar mais pelos processos do que pelas formas, padrões, fatos passíveis de observação imediata. As formas não trariam em si as explicações. São as aparências. Ignorar-se-ia, desta feita, os processos que as elaboraram. A cartografia deveria explorar e tentar resolver cada vez melhor a representação desta dinâmica, em seu total conteúdo.

Numa apreciação dinâmica contar-se-ia como já foi anunciado com:

- representações das transformações de estados e das variações quantitativas absolutas e relativas no tempo (método corocromático qualitativo, método corocromático ordenado, método das figuras geométricas proporcionais e método coroplético);

- representações dos movimentos no espaço (método dos fluxos).

Junto às representações no tempo feitas em mapas, devem-se apor também os gráficos, em especial os evolutivos, como já foi dito, que dentro de certas 
circunstâncias de projetos de atlas podem comparecer. O mesmo pode-se dizer das redes, que especificamente junto aos temas vinculados à História, podem estar presentes para exporem as linhas do tempo (MARTINELLI, 2011).

\subsubsection{O ensino PELO mapa}

O ensino e aprendizagem da Geografia pelo mapa nas duas dimensões básicas da realidade, espaço e tempo, têm como proposta maior a de resgatar a informação que está no mapa. Trata-se de promover a construção do conhecimento de várias áreas de estudo que o ensino fundamental promove com a participação dos mapas.

No caso particular dos atlas municipais pode-se especificar o conhecimento histórico, geográfico e ambiental de tais unidades administrativas. A apreensão da realidade seria feita, portanto, por intermédio da representação daquela em mapa, onde estão presentes , como já foi mencionado, o espaço e o tempo.

$\mathrm{Na}$ atualidade, enfatiza-se que é de incontestável validade ressaltar a relação entre o lugar (o próximo) e o global (o distante) para que a realidade seja conhecida e compreendida pelas crianças do ensino fundamental.

Mais uma vez lembra-se que a realidade traz para si a concepção de totalidade, não como um agregado de espaços considerados separadamente, numa sequência linear. Ela compõe um todo integrado. Como envolve a dimensão tempo, a totalidade está se recompondo continuadamente, portanto, está em movimento. Assim, torna-se o próprio espaço geográfico (STRAFORINI, 2008).

No ensino e aprendizagem da Geografia, onde está presente o mapa, é possível se poder contar com um procedimento de estudo para a compreensão da totalidade trazendo-a para uma abordagem em um nível mais concreto, o lugar, de 
maneira que possa ser possível um fracionamento para depois se proceder a uma recomposição.

O Professor Milton Santos propõe que para compreender o espaço geográfico em sua totalidade é pertinente se lançar mão também das categorias analíticas forma (é o aspecto visível), função (atividade esperada para dar à forma um valor social), estrutura (relação das partes com o todo) e processo (ação contínua indo em direção a um resultado). Estes aspectos poderão estar presentes também nos mapas (SANTOS, 1988).

Atinente às bases metodológicas, a Professora Márcia Maria Duarte dos Santos em 1991 apontava que a literatura sobre o ensino e aprendizagem pelo mapa em geografia, que prevalecia durante o período que incluía o final dos anos 1980 e toda a década de 1990, orientava a se promover uma abordagem sintética. Inicia-se pelo lugar e gradativamente passa-se a parcelas do espaço mundial, cada vez mais amplas, incluindo de forma seriada sempre a parcela anterior. Assim, as crianças com as experiências realizadas no espaço próximo a elas estariam aptas a poder alcançar, passo a passo, o todo distante de maneira satisfatória.

Esta abordagem tem sido a mais explorada por conta de possuir uma maior aproximação com o Construtivismo, que coloca que para a construção do conhecimento seria pertinente se considerar a ação das crianças sobre os objetos (STRAFORINI, 2008: 88).

Porém, no mesmo período podia-se contar com outros escritos que seguiam o encaminhamento inverso, dito analítico, todavia apontando as dificuldades para se chegar a uma aprendizagem coerente. As dificuldades provinham do fato de se começar com toda a superfície terrestre, passando-se, depois, aos poucos para contextos de extensão mais restrita até se chegar ao local. Além dessa questão, não possuía a devida compatibilidade com o desenvolvimento psicológico das crianças (SANTOS, 1991). Coerente com esta linha de pensamento pode-se apontar a proposta de LACOSTE (1976), que discute a validade do conhecimento da cartografia para se ter o domínio do espaço e contar com o mapa como meio de ação e instrumento do saber estratégico. 
O autor advoga que assuntos explanados em uma ampla coletânea de mapas temáticos reunidos ao acaso não constituem temas geográficos. Entretanto, ao se considerar conjugadamente uma variedade de mapas temáticos de um mesmo território fica legítimo considerá-los como temas geográficos. Contudo, a abordagem em variados temas não é suficiente. Deve-se contemplar, de um lado, a articulação dos diferentes níveis de análise em conformidade com as ordens de grandeza em que os fenômenos se manifestam no tempo e no espaço e, de outro, as combinações e contradições que acontecem entre conjuntos espaciais de conteúdos distintos, definidos pelos fenômenos sob apreciação, num mesmo nível de análise.

Entra, assim, em jogo as ordens de grandeza que vão desde o global até o local. Assim, vai interessar se avaliar as interseções entre conjuntos espaciais traçados pelos temas estudados em diferentes níveis de análise, desde os de pequena escala (abordagens globais) até os de grande escala (abordagens locais). Verificar-se-á, assim, que o número de relações espaciais possíveis aumenta conforme se vai das análises em espaços restritos até alcançar as análises em espaços amplos, o que exigirá representações em escalas cada vez menores.

Constata-se que ao iniciar um estudo de geografia por um nível de escada espaço-temporal de detalhe (local) verifica-se que se pode contar com a presença de exígua parte de um conjunto espacial de extensão bem mais ampla. Este só poderá se manifestar plenamente em outro nível de análise, de escala espaçotemporal menor, onde será possível apreciar, agora, a articulação dele com outros conjuntos espaciais que vão compondo a realidade. E, assim, sucessivamente, como fica demonstrado na figura 7. 


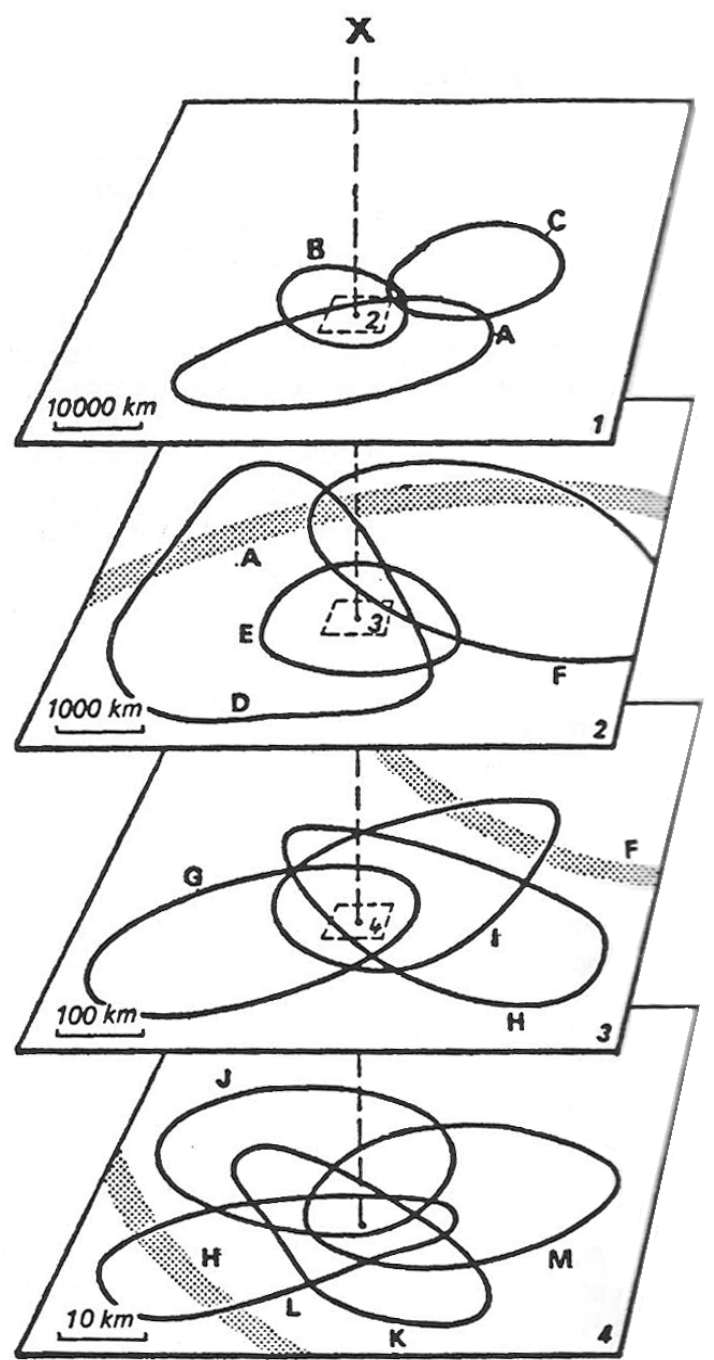

Figura 7 - Os diferentes níveis da análise espacial. Fonte: LACOSTE (1993, p. 94).

Assim, o ensino e aprendizagem da Geografia no ensino Fundamental devem considerar tudo o que cerca a criança, incluindo aspectos do distante que ao mesmo tempo se manifestam no próximo, o lugar.

Tem-se assim, a tecnologia de comunicação, de transportes e de tantos outros setores aproximando os espaços mediante as interligações entre todos os níveis espaciais. Destarte, as escalas espaço-temporais de análise não se cristalizariam mais como instâncias isoladas, estanques, seguindo uma rígida linearidade.

Como o avanço técnico científico-informacional, o lugar não pode mais ser considerado como uma realidade que se encerra em si mesma. O local e o global convivem dialeticamente. Assim, será preciso estimular a compreensão de todo o 
conjunto espaço-temporal que se articula no lugar. Portanto, não teria mais sentido fragmentar o espaço geográfico em partes dissociadas e estanques no tempo e no espaço.

A orientação é de se iniciar o estudo pelo bairro, porém tomado como base para compor as relações dele com o mundo e vice-versa. Assim, não há mais sentido em se considerar relações entre o lugar e o mundo em um único sentido. $O$ que mais importa é o estabelecimento das relações entre os lugares em seus diferentes níveis espaço-temporais, o que acaba perfazendo o global, o mundo. Assim, busca-se a totalidade mundo (STRAFORINI, 2008).

Deve-se, portanto, trabalhar com a categoria lugar junto à realidade dos alunos, sem ficar preso somente aos respectivos limites administrativos, mas sim, abrindo, espaço para contar com possibilidades de contato com outros lugares, portanto com o mundo.

Dever-se-á considerar um encaminhamento para a compreensão do espaço geográfico que vai do lugar ao global, porém com um retorno ao particular com acréscimos enriquecedores (STRAFORINI, 2008). 


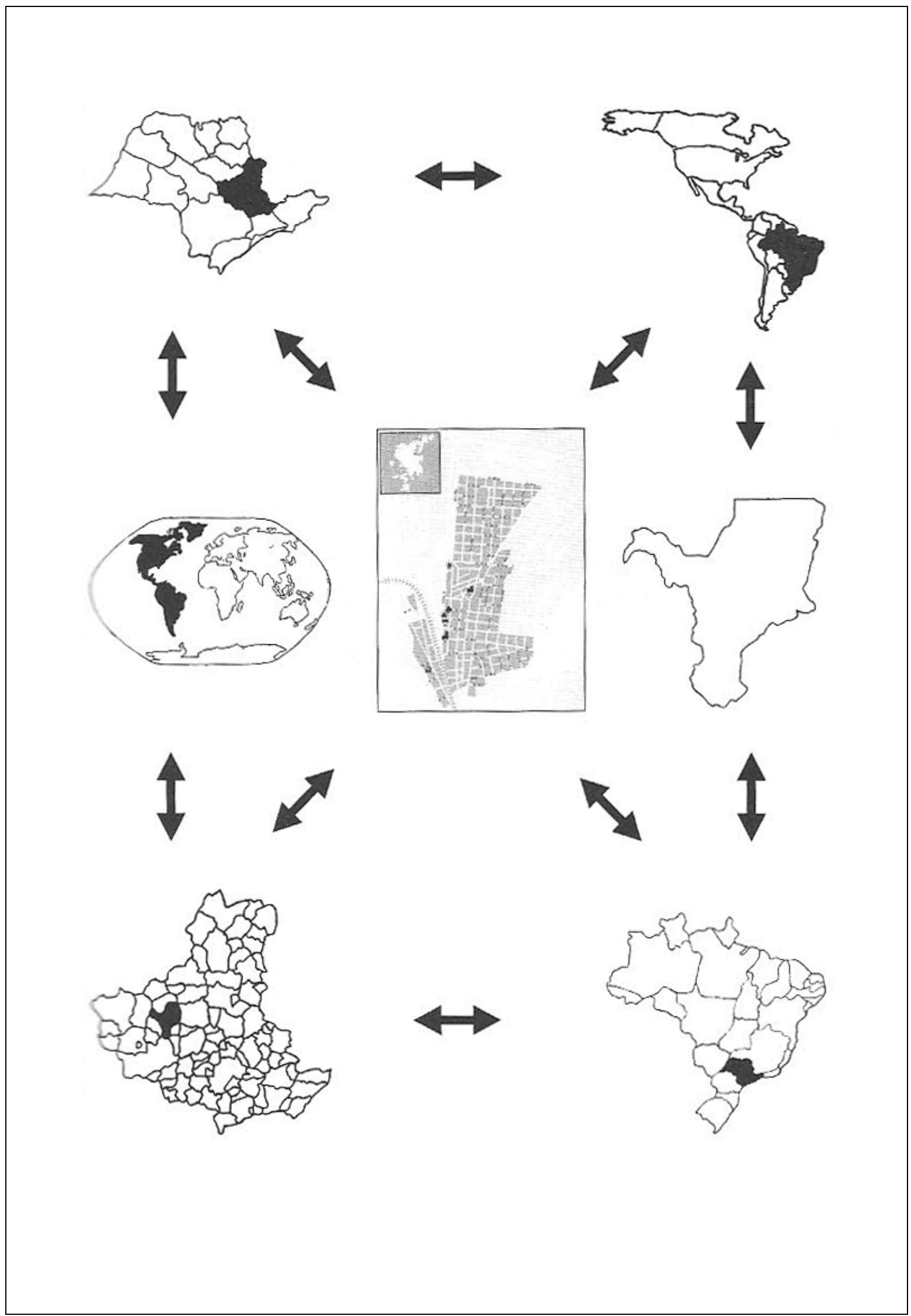

Figura 8 - Modelo explicativo das dimensões escalares: totalidade-mundo. Fonte: STRAFORINI (2008, p. 95) 
A partir do momento em que se está diante da apreensão do conteúdo do mapa pelas crianças, torna-se válido assinalar que PETCHENIK (1977), fundamentada na Psicologia cognitiva, considerou em sua reflexão sobre a Cognição em cartografia, que os mapas não carregariam em si os significados, mas os desencadeariam na cabeça do usuário.

Os signos apreendidos pelo leitor construiriam em sua mente o significado do conteúdo que foi formulado por quem elaborou o mapa. Neste sentido, o significado dos mapas é resultado do arranjo espacial exibido vinculado a um tempo empregado para sua organização. Não se prenderia aos objetos, fatos ou fenômenos, mas sim ao conjunto de relações entre os objetos, fatos ou fenômenos. O leitor deverá reconstruir em sua mente estas relações no espaço e no tempo.

Neste momento, o mapa passa a ter significado. É assim que se opera a compreensão em prol do conhecimento espacial e temporal por meio de mapas.

Trata-se, portanto de se estar diante dos mapas para sua compreensão e uso no momento de se proceder ao ensino e aprendizagem da geografia. Considera-se, assim, o processo de transposição do mapa como representação, de volta para uma imagem mental da realidade.

O uso do mapa na geografia do ensino fundamental compreenderia três atividades básicas: leitura, análise e interpretação, não necessariamente operadas de maneira interdependente (MUEHRCKE, 1983).

$\mathrm{Na}$ leitura determina-se com a mediação do professor, o que o autor do mapa representou mediante a assimilação do título e como procedeu para elaborá-lo. O título levaria em conta a declaração do tema, do lugar onde se desenrola e do tempo referente ao seu desdobramento. Consulta-se, em seguida, a legenda e demais elementos do mapa que the confirmam a propriedade de ser mapa. O completo significado do mapa emergirá com o controle dos símbolos e tomando conhecimento das respectivas descrições apostas na legenda. 


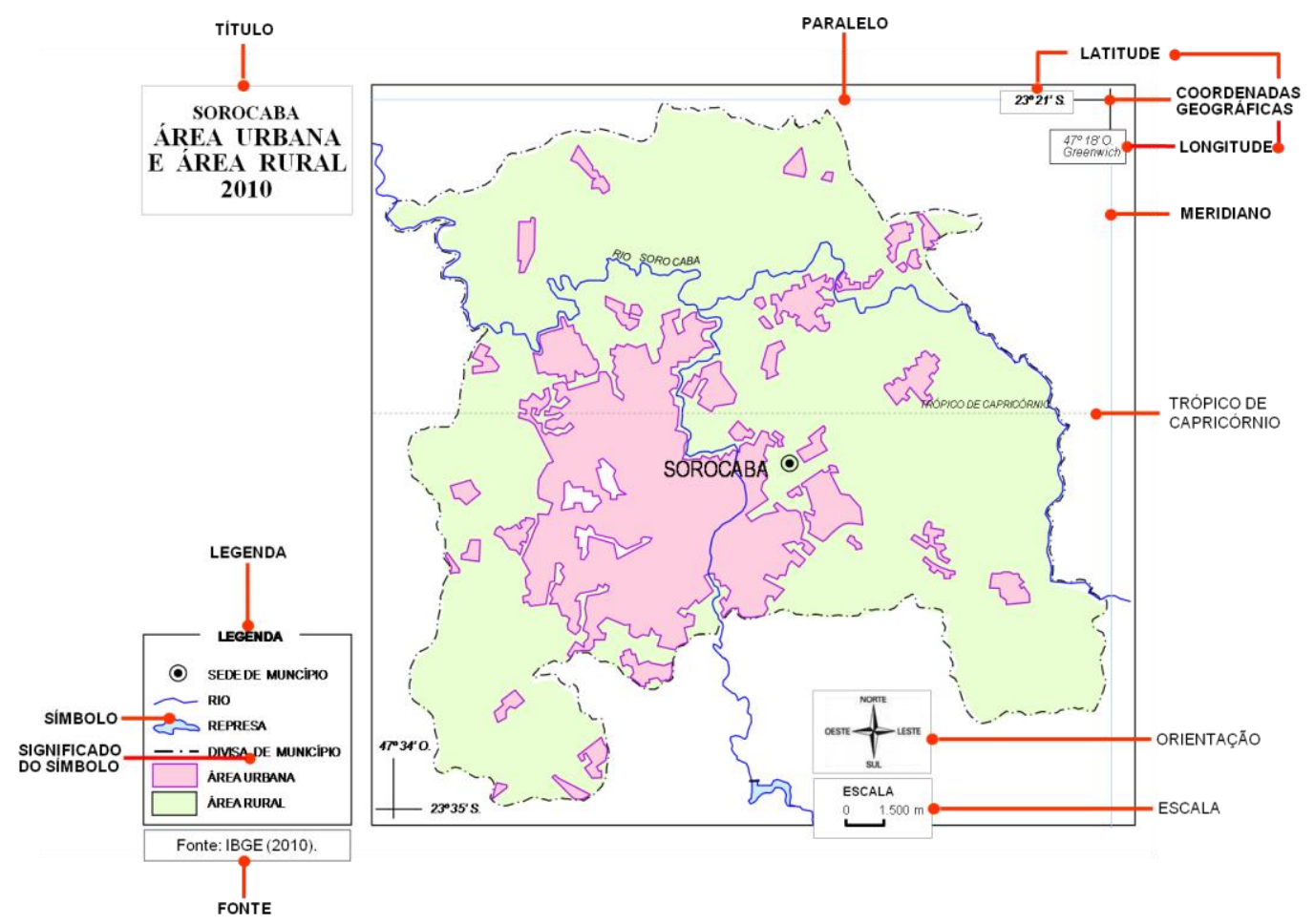

Figura 9 - Os elementos do mapa. Fonte: a autora, 2012.

A análise é a etapa em que se começa a entrever as feições que interessam, as quais poderão revelar algo da geografia expressa no mapa.

Nessa fase, também com a participação do mestre, o objetivo maior é avaliar e descrever relações espaciais em determinado intervalo de tempo, a partir da visualização da imagem de conjunto exibida. Para se obter resultados mais acertados, estas operações mobilizariam contagens e medições que o professor poderá experimentar com os alunos..

Se desperta, agora, a curiosidade, levando o usuário a querer explicar as feições vislumbradas no mapa. Entretanto, deve ficar bem claro, que os mapas por si só não conseguem sugerir as causalidades ou dar as explicações. Serão necessários ulteriores estudos (CLAVAL e WIEBER, 1969).

Passa-se, assim, à etapa seguinte, a da interpretação. É o momento que se vai além do mapa para vislumbrar junto à realidade natural e social retratada, as possíveis causas. Para isso serão necessárias pesquisas complementares. Porém, 
serão válidos também, os conhecimentos já adquiridos pelo leitor. Poderão, dessa maneira, transparecer certas possibilidades de explicação. Reconhece-se que é uma etapa deveras complexa, mas que poderá ser mobilizada numa dose adequada ao preparo dos alunos (MUEHRCKE, 1983).

Por fim, ponderando-se as fases de leitura, análise e interpretação, pode-se declarar o que o mapa revelou. Prova-se, assim, a validade daquele mapa de ter sido feito. Aqui será imprescindível que o mestre possa fazer perceber às crianças tal significado.

\subsubsection{Organização dos atlas geográficos escolares}

Num primeiro momento da organização dos atlas geográficos escolares estaria a definição do recorte espacial de abrangência, delimitando o território para a respectiva apreciação, o que por sua vez, demandaria, também, a uma reflexão sobre as coordenadas geográficas, a escala e a projeção.

Em seguida comparece a avaliação sobre o conteúdo temático, o qual guardará estreita consonância com a definição espacial estipulada.

\subsubsection{O recorte espacial}

O recorte espacial é a operação que irá determinar o âmbito espacial de abrangência para a temática dos atlas. Em geral esta especificação abarca o espaço mundial, que internamente ao próprio atlas se desmembraria em contextos de extensões menores apresentados em abordagens temáticas de maior detalhe. 
Fugindo à regra e de forma até quase inusitada, certos países produzem atlas geográficos escolares em nível nacional. Pode-se citar o caso do "România atlas geografic scolar". É um atlas escolar que faz pare de uma coletânea.

No caso dos atlas geográficos escolares brasileiros podem-se apontar várias alternativas de contextos espaciais perfazendo o seguinte leque de possibilidades: Bairro, Município, Região Metropolitana ou Administrativa, Estado, Grande Região do Brasil, Macrorregião Geoeconômica do Brasil e Brasil.

Este encaminhamento com certeza constituiria um verdadeiro Sistema de atlas, situando cada um dentro de uma coordenação nacional, com o fim de manter a homogeneidade na produção de obras desse tipo. Participando do citado sistema, proporcionaria a complementaridade destas elaborações, escalonando-as desde o nível nacional, regional, estadual, até o âmbito das áreas metropolitanas e municipais (BARBOSA, 1977).

Atinente especificamente ao contexto da cartografia, tanto as coordenadas geográficas, a escala como a projeção estariam vinculadas ao tamanho e formato do território a ser representado numa mesma medida de edição ou de diagramação. Uma extensão ampla requereria uma redução maior, portanto com a adoção de uma escala pequena, atentando para generalidades. Ao contrário, uma extensão limitada, almejando uma abordagem detalhada, solicitaria uma escala grande de significativa ampliação para se contar com os detalhes. Como exemplos destes contrastes seriam os casos da Rússia e do bairro do Butantã, na cidade de São Paulo (SP).

Com relação à projeção, também se estaria diante dos mesmos parâmetros: tamanho e formato do território. Um tamanho grande com formato disposto de maneira bastante extensa na direção Norte-Sul, tal como o Chile, exigiria uma escala pequena e uma projeção bastante específica para acomodar tal disposição territorial. No caso oposto, o da representação da Rússia demandaria também uma escala pequena e uma projeção disposta, mormente na direção Leste-Oeste.

Numa abordagem mais específica, ao se tratar da questão da escala dos mapas, seja em termos gerais como no caso dos atlas escolares, comparecem como 
já se adiantou oportunamente, duas noções de escala: a escala geográfica e a escala cartográfica (CASTRO, 1995).

A Escala Geográfica, como já foi visto procura ir além da localização buscando o conteúdo.

A Escala Cartográfica, por sua vez, busca uma relação significativa entre a realidade e sua representação em mapa.

Porém, é imprescindível que ao se trabalhar a Geografia em sala de aula, deve-se ter o cuidado de não ficar apenas no espaço num sentido absoluto, mas avançar em direção a um entendimento mais completo do espaço geográfico, o qual extrapola aquela noção. Porém, deixando de lado o espaço absoluto, ter-se-ia que buscar outras visões de espaço, temática pesquisada por especialistas, já de há um bom tempo.

É um assunto complexo, como foi ressaltado em parágrafo especifico. É o que hoje se enaltece muito na internet, com os tais mapas que são "cartogramas" ou "anamorfoses". Acredita-se que crianças e jovens, ainda tenham dificuldades de compreensão acerca dessas representações. O fato é que uma representação de uma realidade é sempre uma representação dessa realidade e não é a própria realidade!

\subsubsection{O recorte temático}

A preocupação com a organização de conteúdos temáticos para os atlas geográficos em geral não é recente. A origem de uma orientação mais cautelosa para a estruturação de tais conteúdos, num contexto mais global, pode ser encontrada junto ao desenrolar da história de tais atlas. Nesta pode-se apontar para um momento de considerável impacto para o início da produção de atlas com uma proposta bem definida. Constata-se, assim, que as conquistas científicas empreendidas no final do século XIX, bem como a consolidação de cada ramo do 
saber acabaram por buscar mais rigor científico junto à realização dos atlas, encaminhando propostas cada vez mais centradas em cada país individualmente. Tornaram-se, assim, obras de importância nacional, ganhando a denominação de atlas nacionais.

O primeiro atlas nacional a despertar interesse entre as nações foi 0 da Finlândia (1889). A consequente proliferação destes atlas no início do século $X X$ motivou a busca de recomendações metodológicas para tanto. Foi neste contexto que se inseriu o trabalho coordenado pelo Professor Salichtchev e publicado pela União Geográfica Internacional - UGI, em 1960.

Tais recomendações visavam, em primeiro plano, dispor as qualidades que tais publicações deveriam satisfazer para contarem com uma missão cultural e educativa de alto nível:

- Ter um conteúdo o mais amplo possível;

- Contar com mapas de alto valor científico;

- Poder servir aos fins utilitários;

- Ser acessível a todo leitor instruído.

Assim, a estrutura temática dos aludidos atlas deviam abarcar conhecimentos sobre a natureza e seus recursos, a população, a economia e o desenvolvimento tecnológico, científico e cultural do país. Definiam-se assim cinco grandes partes básicas:

1 - A geografia física;

2 - A população

3 - A economia;

4 - Os problemas culturais

5 - A estrutura política e administrativa.

No Brasil contou-se com o Conselho Nacional de Geografia do IBGE. Com a experiência adquirida com a elaboração do "Atlas Nacional do Brasil" em 1963 estruturado em duas partes, Geral e Regional, os geógrafos do Instituto traçaram as 
orientações metodológicas básicas para a produção dos Atlas, tanto estaduais como regionais. Para tanto, o mesmo órgão instituiu em 1967 a Comissão de Coordenação de Atlas Estaduais. Consolidou-se, assim, uma orientação nos níveis nacional, regional e estadual, dos Atlas abrangendo os respectivos territórios.

Assim foram elaboradas as Normas e Especificações Gerais para o Atlas Nacional/Regional as quais incluíram a Tábua Geral de Matérias e um desdobramento desta nos temas que constituíram o Plano Mínimo para a organização dos Atlas Estaduais (GALVÃO et al., 1971; BARBOSA, 1977).

Foi dentro deste contexto que, em 1966 o Instituto de Geografia da USP, na pessoa do Professor LIBAULT propôs o "Atlas do Estado de São Paulo", como programa de trabalho do Laboratório de Cartografia, com um temário de sua própria elaboração, em consonância com os ditames da UGI (1960). Outros estados seguindo as orientações do Instituto Brasileiro de Geografia e Estatística - IBGE produziram seus atlas.

Passando agora, para o domínio dos atlas geográficos escolares em nível municipal, o empreendimento dos respectivos conteúdos temáticos, demandará o ingresso num contexto que recorre às bases teóricas e metodológicas da História, da Geografia e das Ciências, estas, particularmente na área do Ambiente, como está previsto nos PCNs.

Numa abordagem mais ampla, poder-se-ia considerar também, a proposta de Nimer et al. (1988), de excelente contextualização, fundamentada numa concepção teórica consistente, que fora elaborada para a 3르 edição do "Atlas Nacional do Brasil" do IBGE (1992). Os Autores estabeleceram um temário para desenvolver a representação de seus elementos, desdobrado em três setores intrinsecamente articulados da realidade:

- os Recursos naturais, congregando componentes bióticos e abióticos, sendo vistos como básicos para suprir as necessidades da sociedade humana dentro de determinado quadro histórico, com caráter dinâmico, bem como esgotáveis se não forem considerados diante de um uso sustentável; 
- a Organização espacial, exibindo, através de formas materiais elaboradas pela sociedade, padrões distintos de arranjos espaciais decorrentes das atividades humanas desenvolvidas ao longo do tempo;

- as Mudanças ambientais, como transformações decorrentes dos modos da sociedade travar relações com a natureza mediadas pelo trabalho, que acabariam por desencadear desequilíbrios incômodos ao bem estar comum.

No campo dos atlas geográficos escolares, tomando por base os atlas produzidos pelo IBGE pode-se verificar que, já de há tempo, o Instituto segue um temário que começa pelo mundo e chega ao lugar.

O "Atlas geográfico escolar" do mesmo IBGE editado em 2002 apresenta um plano temático que oferece ao escolar uma introdução à cartografia. Depois passa para o Mundo, tratando dos Continentes, com o mapa físico e o mapa político e, em seguida, cobre toda a Terra com planisférios temáticos. Na sequência apresenta o Brasil com mapas temáticos. Por fim, desdobra o território nacional em suas cinco Grandes Regiões.

Numa edição bastante recente, o "Atlas Geográfico Escolar" do IBGE em sua 5 edição datada de 2009, exibe um temário bastante similar. Após apresentar uma introdução sobre a cartografia dedica-se a abordar primeiro os continentes, depois os planisférios temáticos. Em seguida, focaliza o Brasil com mapas temáticos e, na sequência, vai para as Unidades da Federação sem passar pelas Grandes Regiões.

Já o "Atlas geográfico escolar: ensino fundamental - do $6^{\circ}$ ao $9^{\circ}$ ano" do mesmo IBGE, edição de 2011, declarando que foi elaborado de acordo com os Parâmetros Curriculares Nacionais (PCN), segue um plano temático invertido. Contempla primeiro o Brasil com seus mapas temáticos, passa por algumas regiões metropolitanas selecionadas. Depois segue para as Grandes Regiões, alcançando finalmente, o mundo, primeiro com os continentes para depois contemplar o mesmo por planisférios temáticos. Não apresenta detalhamentos em nível de unidades da federação. 
O "Atlas geográfico: natureza e espaço da sociedade" de Martinelli, edição de 2003, tem uma estrutura diferente. Contempla de início um bê-á-bá do atlas, depois passa para seis regiões metropolitanas ordenadas pelo tamanho populacional; em seguida trata das cinco Grandes Regiões do Brasil complementadas pelas três Macrorregiões Geoeconômicas, fazendo passagem para o território nacional com mapas temáticos. Terminado o Brasil passa para os continentes com mapas políticos e físicos, para em seguida tratá-los com mais detalhes em quatro temas: População, Agropecuária, Indústria e Questão ambiental. O atlas se encerra com o mundo apresentado numa seleção de planisférios temáticos (MARTINELLI, 2003).

Por sua vez, o "Moderno atlas geográfico" de autoria da Professora Graça Maria Lemos Ferreira, edição de 2011, organiza um sumário que contempla os seguintes grandes tópicos: Cartografia, Brasil com mapas temáticos, Grandes Regiões do Brasil, Continentes, desdobrados em vários temas e por fim Planisférios temáticos (FERREIRA, 2011).

Acredita-se, assim, que há necessidade de incorporar noções e conceitos no sentido de desmistificar o mapa como uma mera representação cartográfica fragmentada do espaço a partir do tempo e das dimensões local, regional e global.

\footnotetext{
La primera de las conclusiones a la que hemos llegado es la necesidad de realizar una acción para que el niño pueda llegar a una lectura correcta del mapa. No se puede pensar que el simples trabajo con los mapas de grande escala les puede proporcionar las destrezas suficientes para una comprensión de la cartografía de pequeña escala. (PELETEIRO; ARIAS, 1998, p.8-9).
}

Por outro lado, reconhece-se que, hoje, uma metodologia para os atlas escolares, pensada a partir do entendimento de que o estudo da realidade seguiria a sequência que se inicia pelo lugar, passando pela cidade e pelo país até chegar ao mundo, não é mais a desejável. Pois a elucidação e reflexão do lugar não podem ficar mais restritas ao lugar em si mesmo. Hoje, dentro de uma geografia da atualidade, as escalas se superpõem e se relacionam. Acabam se embutindo umas nas outras (MOLES e ROHMER, 1972; STRAFORINI, 2008).

Diante das argumentações apresentadas, entende-se que um recorte temático para o atlas, cuja programação de um protótipo é veiculada pelo Capítulo 
IV, seria aquela que apreciasse uma introdução para encaminhar o aluno a se adentrar ao atlas, bem como a adquirir o conhecimento sobre seu município. 
CAPÍTULO IV

\section{IMPLEMENTAÇÃO DE UM PROTÓTIPO DE ATLAS ESCOLAR PARA O MUNICÍPIO DE SOROCABA - SP}




\section{CAPÍTULO IV - IMPLEMENTAÇÃO DE UM PROTÓTIPO DE ATLAS ESCOLAR PARA O MUNICÍPIO DE SOROCABA - SP}

\subsection{O município}

A implementação de um protótipo de atlas geográfico escolar para 0 município de Sorocaba (SP) se insere no domínio dos Atlas escolares locais. A produção de material didático nesse nível de abrangência territorial vem se confirmando cada vez mais desde a década de 1990, quando teve início uma maior preocupação com abordagens geográficas acerca do lugar no momento em que este não pôde mais ser levado em conta como uma manifestação que se completa em si.

Empreende-se o citado protótipo de atlas escolar, voltado para os Anos iniciais do Ensino Fundamental, respeitando a faixa etária e domínios cognitivos. AGUIAR, L. (2012) observa que o exercício da imaginação geográfica pode ser despertado nos alunos dos anos iniciais do ensino fundamental, através dos Atlas Escolares Municipais. De fato, os Atlas Escolares publicados recentemente contém, além dos textos explicativos, uma série de recursos visuais, tais como, mapas, fotografias, linhas do tempo, infográficos e gráficos.

Entende-se que nesse momento escolar é dada importância à necessidade de o aluno conhecer o município no qual ele vive, suas condições de vida e das famílias as quais ele pertence historicamente. Inclui-se também a compreensão dos diferentes elementos do mundo, presentes em seu dia a dia e relacionados à diversidade de lugares e de épocas onde o todo não é visto como a soma das partes. Assim, busca-se entrever a compreensão do global que se vincula ao lugar. Com isto deixa-se de lado a prática de se fracionar o espaço geográfico em porções indiferentes no tempo e no espaço (SANTOS, 1994; STRAFORINI, 2008).

A escolha desse município deu-se em função de alguns fatores. O município de Sorocaba oferece importância política e econômica tanto para a história do Estado de São Paulo como para o Brasil, em função das transformações pelas quais o município passou e ainda passa, pela relativa viabilidade e disponibilidade de 
dados e, em especial pela pesquisadora vivenciar a realidade do município em questão. Por outro lado, a justificativa ganha peso pelo fato de o município não possuir ainda um atlas escolar desse tipo.

Assim, os temas do atlas escolar de Sorocaba-SP, foram selecionados com base na própria realidade do município, nos Parâmetros Curriculares - PCNs e na oportuna experiência da pesquisadora em sala de aula. Ele será organizado levando-se em conta duas dimensões essenciais da realidade: o espaço e o tempo. A construção e representação das noções de espaço e de tempo serão básicas para que a criança possa se situar dentro do quadro da realidade, o município de Sorocaba.

Nesse sentido, será um atlas histórico, geográfico e ambiental, para o conhecimento local, que busca viabilizar a conexão entre os conhecimentos desses campos científicos ao saber do aluno, com vistas a uma visão integradora do seu espaço vivido e de seus valores. Desta forma, a proposta deste atlas escolar está pautada no contexto histórico e social das ações humanas e suas interações com a natureza.

O município em apreço está localizado na porção sudoeste do estado de São Paulo, sendo cortado pelo Trópico de Capricórnio. Sua posição geográfica, dada pelas linhas extremas que configuram o quadro que inclui o território, como aponta o IBGE, é:

\begin{tabular}{|cc|lc|}
\hline \multicolumn{2}{|c|}{ Latitude Sul } & \multicolumn{2}{c|}{ Longitude Oeste de Greenwich } \\
\hline Extremo Norte & Extremo Sul & Extremo Leste & \\
\hline $23^{\circ} 21^{\prime} \mathrm{S}$. & $23^{\circ} 35^{\prime} \mathrm{S}$. & $47^{\circ} 18^{\prime} \mathrm{O} . \mathrm{Gr}$. & $47^{\circ} 34^{\prime} \mathrm{O} \mathrm{Gr}$. \\
& & & \\
\hline
\end{tabular}

Quadro 1 - Coordenadas Geográficas do Município de Sorocaba. Fonte: Prefeitura do município de Sorocaba-SP, 2012.

Seu território é atravessado pelo Rio Sorocaba, afluente da margem esquerda do Rio Tietê, primeiro com um segmento que vem de Sul para Norte, depois, na altura do Bairro Jardim Imperatriz sofre uma inflexão, seguindo para Oeste. 
Conta atualmente com uma população total, segundo os dados do IBGE $2010^{13}$, de 586.311 habitantes.

Sorocaba, em termos de substratos geológicos, situa-se no contato entre o Planalto Atlântico, domínio de rochas cristalinas (relevos mais elevados) e a Depressão periférica, domínio de rochas sedimentares antigas da Bacia Sedimentar do Paraná (relevo mais ondulado e altitudes mais baixas). O município está, assim, posicionado na borda do Planalto Atlântico, onde se articula a Linha de Quedas Apalachianas. Daí a idéia de "terra rasgada" concebida pelos seus primeiros habitantes.

O nome Sorocaba tem a sua gênese no tupi "soroc" que significa rasgar e "aba" que é um morfema nominalizador. Desta forma, "Sorocaba", significa "rasgão" ou "terra rasgada". O território se insere na Região Administrativa de Sorocaba que fica a sudoeste do estado de São Paulo e conta com 80 municípios.

${ }^{13}$ Dados divulgados no Diário Oficial da União (04/11/2010). 


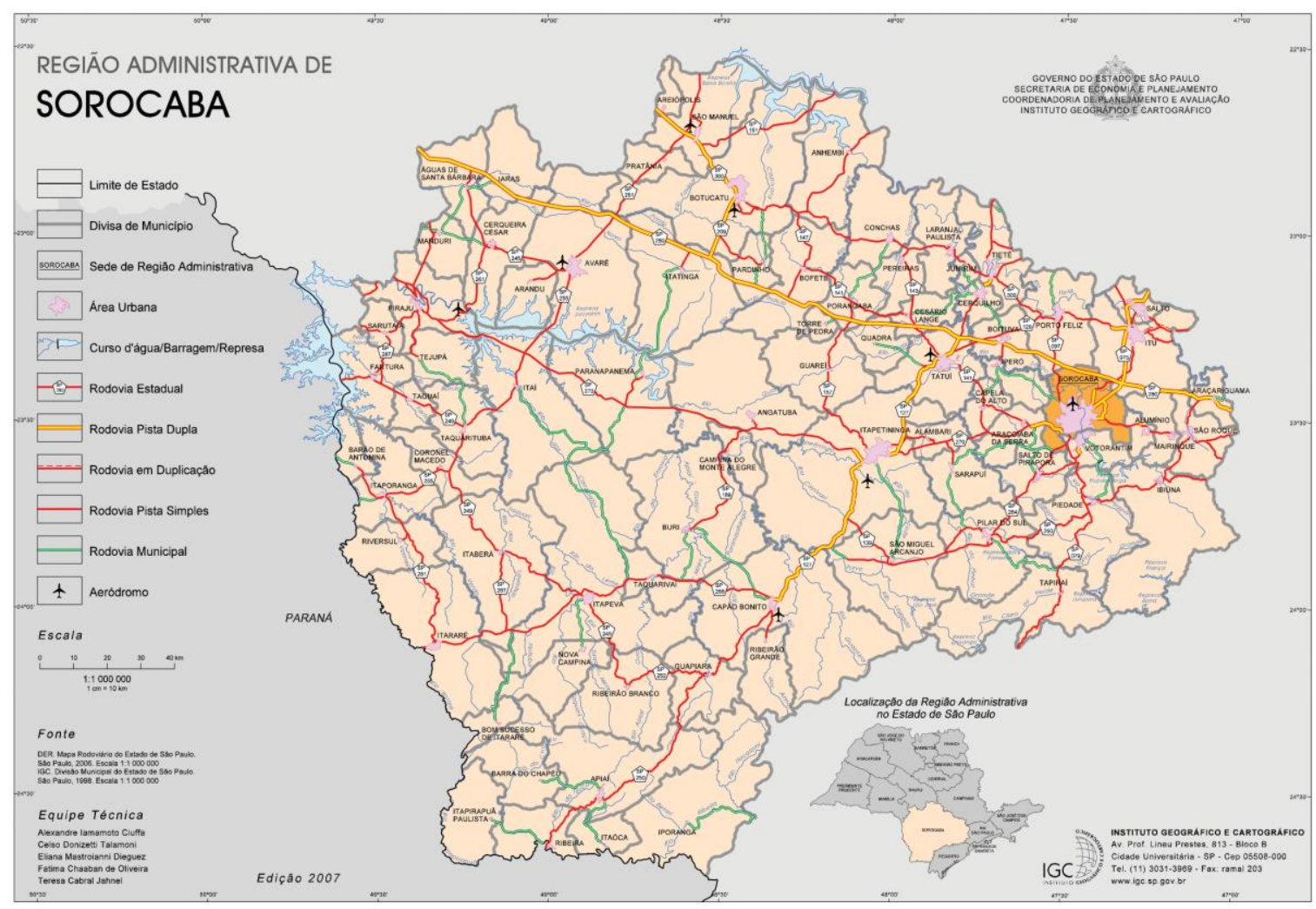

Figura 10 - Região Administrativa de Sorocaba - SP. Fonte: IGC, 2007.
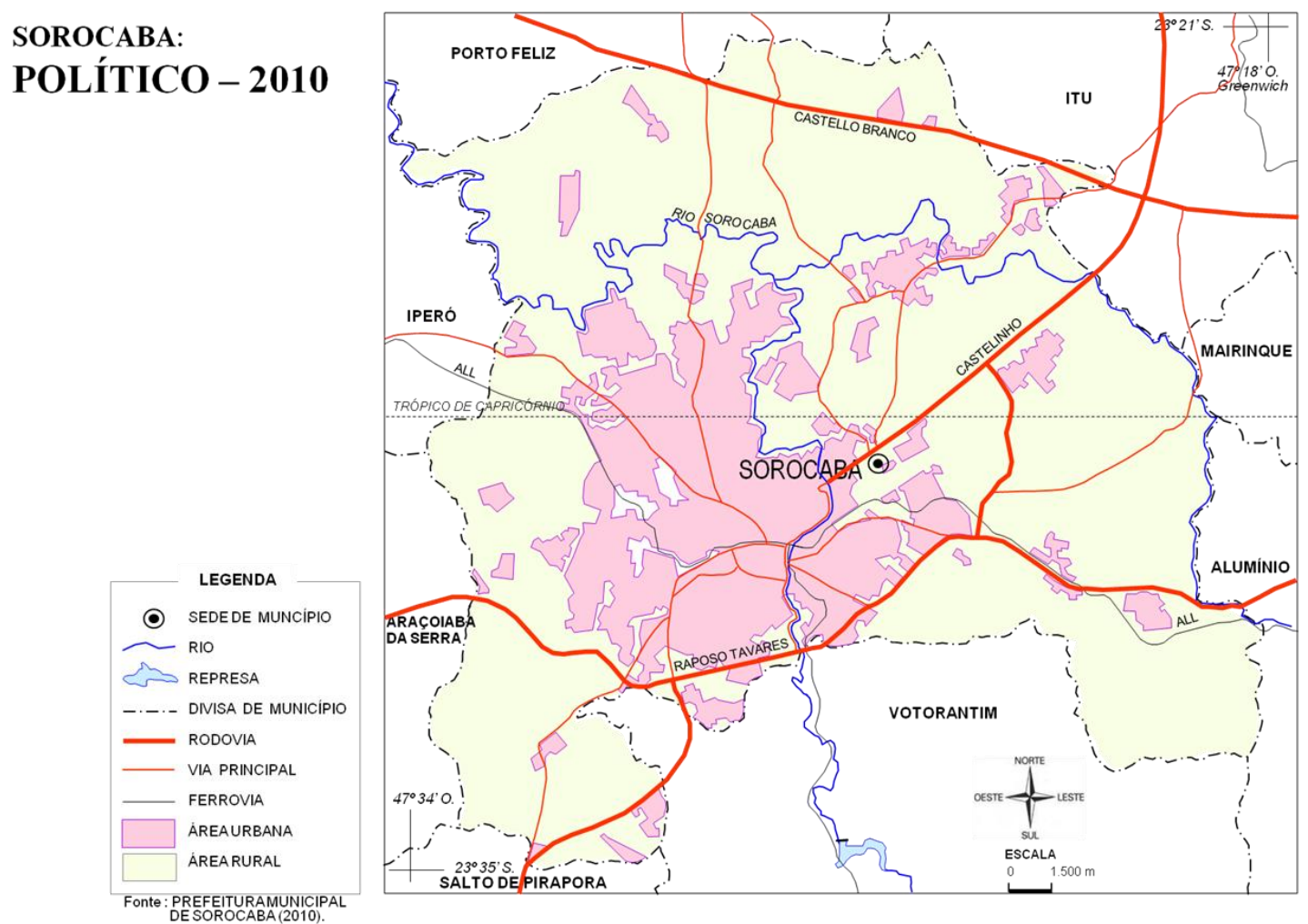

Figura 11 - Mapa político do Município de Sorocaba. Fonte: Prefeitura de Sorocaba, 2010. 


\subsection{O Plano temático}

Um aspecto de grande significado na organização de um atlas geográfico escolar, aqui especificamente para o caso do município de Sorocaba (SP) é a organização de seu plano temático. Expõe seu conteúdo. Abre-se por completo à frente do leitor interessado.

Para esta elaboração retomar-se-á aqui, como base de apoio, as considerações expostas com respeito ao que tange ao conteúdo temático junto à organização dos atlas geográficos escolares do capítulo III.

Em se tratando do protótipo de Atlas para o Município de Sorocaba faz-se referência à professora Rosângela Doin de Almeida, que em sua Tese intitulada: "Integrando Universidade e Escola por meio de uma pesquisa em colaboração" (2001, p.41), apresenta um estudo que resultou na produção de atlas para os alunos do Ensino Fundamental, para os municípios de Rio Claro (SP), Limeira (SP) e Ipeúna (SP). Esse estudo veio ao encontro da necessidade de pesquisas no Brasil relacionadas ao uso de mapas municipais por alunos de 9 a 12 anos.

Assim, com base na pesquisa acima citada, pode-se dizer que a escolha e organização do recorte temático do Protótipo do Atlas Escolar de Sorocaba passaram pelo estudo e discussão do Currículo do ensino fundamental lastreado nos Parâmetros Curriculares Nacionais (Brasil, 1998) e nas Orientações Curriculares do Estado de São Paulo. Entretanto, mesmo considerando esta base, os temas escolhidos fundamentam-se, também, na importância social, na identidade e formação intelectual do aluno.

Quanto aos conteúdos (noções, conceitos, habilidades) das páginas temáticas, estes devem vir não apenas ao encontro da escolarização dos alunos, isto é, ao ano escolar em que o aluno se encontra. Mas, é preciso suprir possíveis falhas na prática do ensino dos conteúdos das disciplinas e da representação gráfica, na superação da ausência ou precários conhecimentos prévios que muitas vezes advogam a favor dos professores como justificativa para não avançarem nos conteúdos. 
O objetivo maior das representações gráficas, incluindo tanto os mapas como os gráficos e as redes, configuradas em cada página temática é permitir que os alunos/usuários consigam desenvolver uma leitura crítica comentada dos conteúdos representados nos mapas e outras representações. Isto é, descobrir o que o mapa, gráfico ou rede revelou. No entanto, essa leitura deve começar com níveis de compreensão mais elementares até alcançar níveis mais complexos. O primeiro nível abarca o entendimento geral (sincrético) do tema, em seguida, leituras das distintas representações por meios cartográficos, iconográficos ou textuais, e por fim, chega-se à síntese, num nível mais complexo. Segundo a pesquisa em pauta, esses níveis de leitura norteiam a "Legibilidade da página", e está pautado na pesquisa em sala de aula. Isto é:

Dessa maneira, pensamos que alunos das séries iniciais poderiam entrar no tema pelo título, dirigindo-se para a leitura das imagens (fotos ou gravuras), passando para outros suportes como mapas, box e gráficos. Caso ainda não dominassem bem a linguagem cartográfica, deixariam o pleno entendimento da representação para um momento mais adiante, porém, já com uma noção sobre a temática da página. O mesmo procedimento seria cabível para o entendimento do texto, que poderia ser lido, explicado pelo professor, e retomado noutra ocasião. (ALMEIDA, 2001, p.42)

Entretanto, entende-se que nesse momento o escolar pode explorar a decodificação dos símbolos da legenda, isto é, a relação entre significante e significado dos símbolos, o primeiro passo da leitura do mapa após ter assimilado a exposição do título. Porém, não se deveria parar ai, ter-se-ia que trabalhar também a relação entre os significados dos signos. Assim, por exemplo, não basta ler na legenda do mapa do relevo representado por faixas de cores hipsométricas numa sucessão de caixas com cores quentes, indo do claro para o escuro, que tal cor significa a faixa de altitudes entre 300 e 400 metros. Dever-se-ia também praticar junto aos alunos qual o significado da relação que existe entre as altitudes do relevo.

As recomendações acima resolvem boa parte dos problemas relacionados à escolha dos temas que podem fazer parte de um atlas para o conhecimento do lugar. Porém, questões de caráter específico da "localidade" podem ficar a desejar. Daí a necessidade de uma discussão, reflexão e posicionamento de como desenvolver um atlas para o conhecimento do lugar, ou seja, implementar um protótipo adequado que possibilite compor um material didático, no caso, o Atlas 
escolar de Sorocaba, que seja apropriado para as crianças na idade escolar das Anos iniciais do Ensino Fundamental.

Os temas tratados, em boa parte dos atlas escolares para o conhecimento do lugar, o município, abordam: Localização; Divisão Político-administrativa; Rede viária; Bairros e Núcleos Rurais; Habitantes primitivos ou pioneiros; Ocupação do território; Atividades econômicas, Bacias hidrográficas, Morfologia; Recursos naturais; Saneamento básico; Lazer e Turismo. Assim, parte da diversidade de conteúdos está atrelada às peculiaridades do lugar.

Fruto de uma revisão sobre a literatura atinente ao assunto, dos Parâmetros Curriculares Nacionais (Brasil, 1998), dos Parâmetros Curriculares do Estado de São Paulo, da prática em sala de aula na rede pública e particular, bem como de um estudo específico sobre o Município de Sorocaba, considera-se pertinente um temário consoante com as bases metodológicas da História, da Geografia e das Questões ambientais. Sempre considerando as relações entre a sociedade e a natureza, mediada pelo trabalho, dentro de um processo histórico-social. Um temário que ajude o escolar a problematizar a realidade, articular a sua compreensão prévia com os textos, figuras e representações em mapas, somando assim, conhecimento à sua formação cultural, social e científica. Neste sentido ter-se-ia o seguinte plano temático: 


\section{INGRESSANDO NO ATLAS}

Apreensão e representação do espaço A representação da realidade espacial passo a passo

Os elementos do mapa

Como são feitos os mapas

As novas tecnologias

\section{SOROCABA: O LUGAR E O GLOBAL}

Do lugar para o Mundo e do Mundo para o lugar

Todas as partes do mundo interligadas

O Município

Símbolos

\section{SOROCABA: SUA HISTÓRIA}

Linha do Tempo

Pré-História sorocabana

Presença do homem branco

Bandeirismo

Do povoado ao município

Tropeirismo

Liberalismo

Ferrovia

Industrialização

Terceirização

Parque Tecnológico

\section{SOROCABA: FORMAÇÃO DO TERRITÓRIO}

Capitanias Hereditárias

Municípios Originários

Evolução do desmembramento territorial e administrativo do termo da Vila de Nossa Senhora da Ponte de Sorocaba

Território atual do município
5 SOROCABA: GEOGRAFIA

Político

Relevo

Hidrografia

Geologia e recursos minerais

Vegetação

Clima

Área urbana e área rural

Uso da terra e cobertura do solo

População

Indústria

Rede Viária

Saúde

Educação

Turismo

\section{SOROCABA: AMBIENTE}

Saneamento Básico

Lixo

Reciclagem

Ambiente

\section{SOROCABA EM ZONAS}

A divisão de Sorocaba em Zonas

Zona Norte

Zona Sul

Zona Leste

Zona Oeste

Zona Centro

\section{REFERÊNCIAS}




\subsection{A diagramação das pranchas temáticas}

Para organizar de forma conveniente aos leitores as pranchas temáticas do protótipo, adotou-se a folha de papel no formato A4, no modo paisagem.

Cada tema associado ao município de Sorocaba ocupa, geralmente, duas páginas espelhadas.

Com relação à diagramação, na página par encontram-se o título do tema, o texto (fonte Arial, corpo 12, espaçamento simples entre linhas) e as figuras fotografias, desenhos, croquis, infográficos ou gráficos.

A página ímpar, por sua vez, contém o mapa e a legenda correspondente. Para os mapas municipais a escala adotada foi de 1:150.000, enquanto que para os mapas das zonas, escolheu-se a escala 1:80.000.

Além disso, foram incluídos dois encartes especiais quando houve a necessidade de adicionar dois mapas numa mesma página ímpar. A seguir, tem-se um exemplo de uma prancha temática envolvendo um mapa municipal.

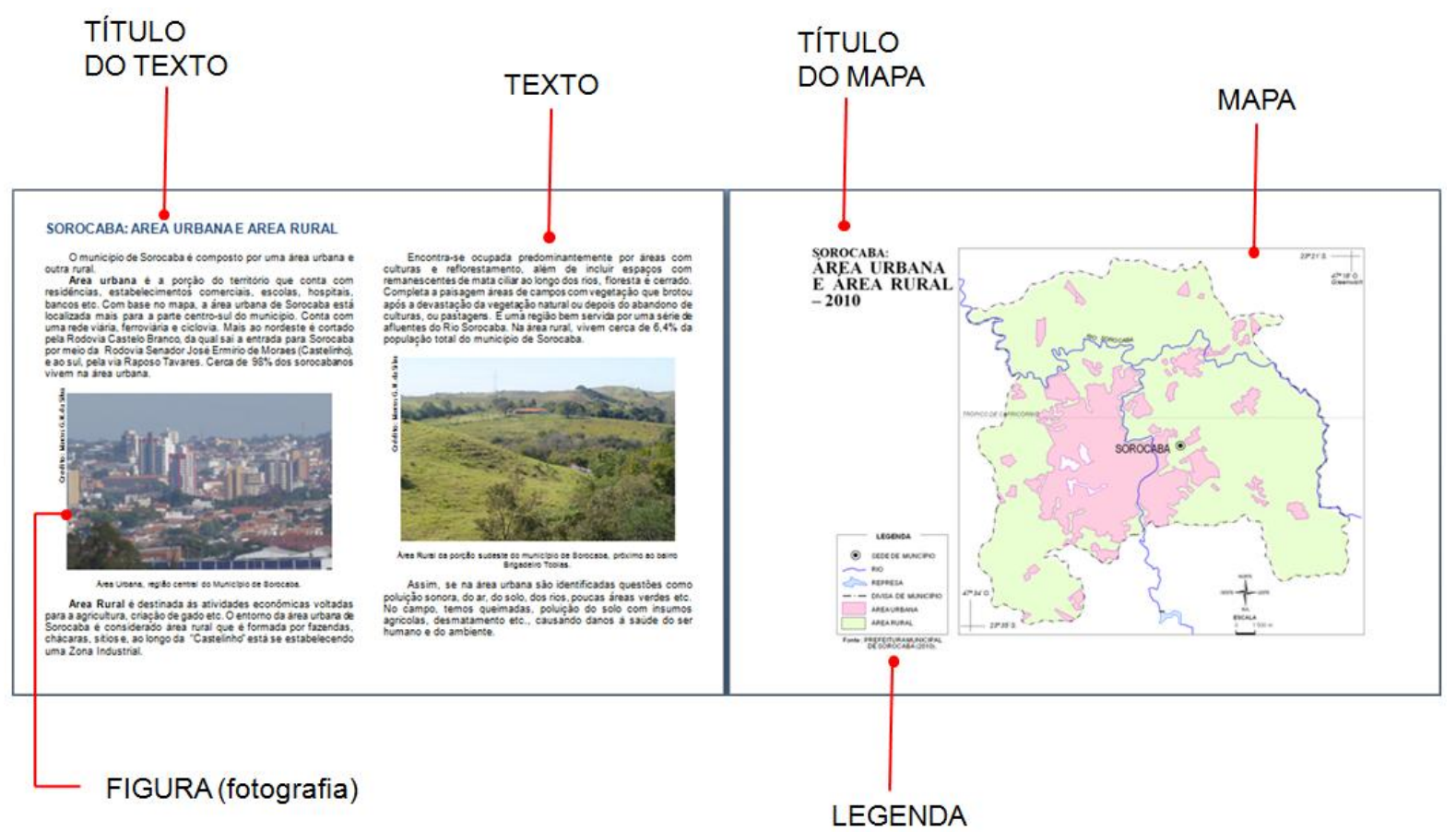

Figura 12. Exemplo de uma Prancha Temática - Sorocaba: Área urbana e área rural - 2010. 


\section{CAPÍTULO V}

\section{O PROTÓTIPO NA SALA DE AULA}




\section{CAPÍTULO V - O PROTÓTIPO NA SALA DE AULA}

Chegou o momento em que o protótipo do Atlas Escolar de Sorocaba-SP: História, Geografia e Ambiente - Anos Iniciais do Ensino Fundamental tornou-se apto para sua avaliação em sala de aula na rede escolar do Município de Sorocaba (SP). Assim, deu-se início a uma pesquisa de caráter qualitativo e quantitativo.

O objetivo foi identificar o que precisaria ser corrigido nas Pranchas Temáticas do protótipo para torná-las significativas aos seus usuários: professores e alunos. O termo Prancha Temática deve ser entendido como a página ímpar na qual consta o texto, figuras, infográficos e gráficos e, a página par espelhada composta pelo mapa temático.

Assim, a idéia inicial era aplicá-lo nos Anos Iniciais, primeiramente, na Rede Municipal e, em seguida na Rede Estadual do Município de Sorocaba. Para tanto, os contatos com diretores e coordenadores das escolas municipais e estaduais iniciaram-se no dia 20 de abril de 2012.

Foram apresentados o Protótipo do Atlas Escolar e uma justificativa da necessidade de avaliação de suas pranchas temáticas, para os coordenadores pedagógicos de duas escolas municipais. Os coordenadores entenderam a importância da pesquisa, mostraram-se interessados, porém, ressaltaram a necessidade de uma autorização vinda da Secretaria da Educação (Sedu) do município de Sorocaba, que responde pelo planejamento, coordenação e supervisão das atividades educacionais a cargo do Município, no âmbito da Educação Infantil, Ensinos Fundamental, Médio, Supletivo e Especial. Infelizmente, a resposta do Sedu foi desfavorável, sendo que a justificativa ficou por conta dos resultados negativos da aplicação de outras pesquisas acadêmicas na sala de aula.

O passo seguinte foi buscar uma oportunidade na rede estadual. Após o levantamento das unidades de ensino, foram escolhidas as Escolas Estaduais "Baltazar Fernandes" e "Brigadeiro Tobias" para colaborarem na pesquisa. Os convites foram feitos e aceitos pelas duas escolas citadas. 
Nos itens seguintes, em termos gerais, será apresentado um breve esclarecimento sobre as duas escolas em questão, escolha e avaliação das pranchas temáticas de alguns capítulos do protótipo, atividades desenvolvidas pelos alunos e análise dos resultados.

\subsection{As Escolas participantes do processo de avaliação}

\subsubsection{Escola Estadual Baltazar Fernandes}

A Escola Estadual Baltazar Fernandes recebeu este nome em homenagem ao fundador do Município de Sorocaba e oferece Ensino nas Séries/Anos Iniciais do Ensino Fundamental. Está situada na Rua Oswaldo Cruz, 684 - Vila Santana, região Norte do município, próximo a região central.

O primeiro contato com a escola em questão deu-se no dia 30 de abril de 2012 por telefone. Por essa ocasião, foi apresentada uma proposta de trabalho para a Coordenadora pedagógica, que por sua vez, ficou de levá-la para a Diretora. O aceite foi imediato e, na oportunidade, a Coordenadora indagou sobre a possibilidade de apresentar a pesquisa, para os professores da escola, durante uma reunião de HTPC (Horas de Trabalho Coletivo Pedagógico). Uma vez acordado o conteúdo e o formato da apresentação, a reunião foi agendada para o dia 22 de maio de 2012.

Assim, na ocasião realizou-se uma apresentação, utilizando o MS-Power Point, da proposta do protótipo do Atlas escolar para Sorocaba, bem como exemplos dos exercícios para serem trabalhados com os alunos, para um grupo de 30 professoras, além da vice-diretora.

A princípio, a proposta era orientar as professoras, para que elas mesmas se colocassem na situação de usuárias do Atlas frente aos seus alunos. Para tanto, 
elas contariam com um apoio, isto é, uma orientação para a exposição e adequação do conteúdo do tema da página do atlas aos conteúdos do programa que já vinham desenvolvendo em sala de aula, confecção dos exercícios e, por fim, a aplicação das pranchas temáticas em forma de avaliação individual. Para tanto, seriam realizadas reuniões com grupos menores de professoras de cada ano escolar. Nestas reuniões seriam discutidos os conteúdos dos exercícios, os procedimentos didático-pedagógicos necessários para a mediação do saber com os alunos, bem como possíveis alterações e adaptações do conteúdo das pranchas temáticas em termos dos textos e dos mapas, em função da experiência adquirida na sala de aula.

Por essa ocasião, dentre as vinte e cinco professoras, doze manifestaram interesse em colaborar com a Avaliação do Protótipo, porém, não se sentiam preparadas para tal empreendimento, alegando que não tiveram na sua formação acadêmica (Pedagogia), uma disciplina voltada para Cartografia Escolar. Comentaram que trabalhavam mais os conteúdos de matemática e português, pois eram cobradas no SARESP ${ }^{14}$. Mas, entendiam que tanto elas quanto os seus alunos precisavam dominar a linguagem da representação gráfica dos mapas e conhecer bem o município onde vivem. Assim, sugeriram que todas as pranchas do Capítulo I - Ingressando no Atlas (iniciação cartográfica) fossem aplicadas, pois caso contrário, não teriam como avaliar as demais pranchas temáticas. As demais professoras que não demonstraram interesse na pesquisa alegaram que eram da área de educação física, artes ou mesmo que seus alunos ainda estavam sendo alfabetizados.

O passo seguinte foi entregar às doze professoras, do $2^{\circ}$ ao $5^{\circ}$ ano, um questionário contendo todos os temas do Protótipo do atlas escolar, para que elas escolhessem os que julgavam mais importantes para serem trabalhados com os seus alunos. Os formulários foram preenchidos e entregues para a pesquisadora. $A$ seguir apresenta-se o quadro referente aos Capítulos e Pranchas Temáticas do Protótipo do Atlas, selecionadas pelas professoras da Escola Estadual Baltazar Fernandes para os anos $2^{\circ}, 3^{\circ}, 4^{\circ}$ e $5^{\circ}$ anos.

\footnotetext{
${ }^{14}$ SARESP é o Sistema de Avaliação de Rendimento Escolar do Estado de São Paulo Corresponde a uma avaliação externa em larga escala da Educação Básica, aplicada a cada ano desde 1996 pela Secretaria da Educação do Estado de São Paulo.
} 
Pranchas Temáticas do Protótipo selecionadas pelas professoras da Escola Estadual Baltazar Fernandes

\begin{tabular}{|c|c|}
\hline Capítulos & Pranchas Temáticas e Turmas \\
\hline Capítulo I - "Ingressando no Atlas". & $\begin{array}{l}\text { Todas as Pranchas Temáticas para } \\
\text { todas as turmas. }\end{array}$ \\
\hline Capítulo II & $\begin{array}{l}\text { Do lugar para o mundo } \\
\text { As relações do mundo com o lugar } \\
\text { Turmas: } 3^{\circ} \text { anos } A, B, C \text { e } E\end{array}$ \\
\hline Capítulo III - Sorocaba: sua história & $\begin{array}{l}\text { Todas as Pranchas Temas } \\
\text { Turmas: } 4^{\circ} \text { ano A e } 5^{\circ} \text { ano } \mathrm{C}\end{array}$ \\
\hline $\begin{array}{c}\text { Capítulo IV - Sorocaba: Formação do } \\
\text { Território }\end{array}$ & Não houve nenhuma solicitação \\
\hline Capítulo V - Sorocaba: Geografia & $\begin{array}{l}\text {.Relevo } \\
\text {.Clima } \\
\text {.Uso da terra e cobertura do solo. } \\
\text {.Área Urbana e Rural } \\
\text { População. } \\
\text { Turmas: } 5^{\circ} \text { anos C, D e E }\end{array}$ \\
\hline Capítulo VI - Sorocaba: Ambiente & $\begin{array}{l}\text { Saneamento Básico } \\
\text { Turmas: 5 ano C, D e E }\end{array}$ \\
\hline Capítulo VII - Sorocaba: Zonas & $\begin{array}{l}\text { Zona Centro } \\
\text { Turmas: 4ํㅗ A e C; 5ํano C, D e E. }\end{array}$ \\
\hline
\end{tabular}

Quadro 2- Pranchas Temáticas do Protótipo selecionadas pelas professoras da Escola Estadual

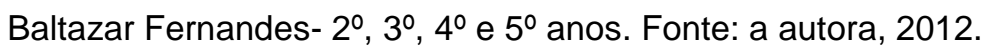

O quadro das pranchas temáticas para a avaliação acima deixa claro que para as professoras um trabalho voltado para a Iniciação Cartográfica seria de suma importância. Pode-se dizer também que quase todos os capítulos do protótipo apresentaram temas de interesse para as professoras. O capítulo IV - Sorocaba: Formação do Território foi o único que nenhuma professora demonstrou vontade em trabalhá-lo na sala de aula.

Logo após a escolha dos temas, foi decidido que o trabalho começaria com as turmas dos $2^{\circ}$ anos e depois seguiria com as turmas do $3^{\circ}, 4^{\circ}$ e $5^{\circ}$ anos. A comunicação entre professoras e pesquisadora se daria através de e-mails e 
reuniões com grupos de professores dentro do horário da HTPC. Foi selado, então, o acordo. Solicitou-se também, na ocasião, o encaminhamento de um Requerimento à direção da Escola e uma proposta de trabalho.

Assim, no dia 28 de maio de 2012, dirigiu-se o Requerimento à Diretora da Escola Estadual Baltazar Fernandes, solicitando a oportunidade de avaliar a adequação do protótipo de Atlas Escolar aos usuários, ou seja, professores e alunos das Séries/Anos Iniciais do Ensino Fundamental (2ำ 3ำ 4ำ e $5^{\circ}$ anos). Anexou-se a este requerimento uma proposta de trabalho para cada um dos anos iniciais, com os conteúdos a serem trabalhados e cronograma, além de uma Declaração de que a aplicação da pesquisa não teria fins lucrativos. O pedido foi deferido na mesma data, com algumas condições, ou seja, não seria permitido filmar e gravar as aulas. Desta forma, o caderno de campo foi o grande aliado para os registros das intervenções.

De antemão, se gostaria de ressaltar que apesar do interesse manifestado pelas duas professoras do $4^{\circ}$ ano, as professoras Valdirene e Rogéria, a aplicação das Pranchas Temáticas do protótipo selecionadas por elas (ver quadro 2) não foi possível, em virtude destas encontrarem-se de licença nos meses previamente agendados.

\subsubsection{Escola Estadual Brigadeiro Tobias}

Esta escola recebeu o nome do Brigadeiro Rafael Tobias de Aguiar que liderou a Revolta Liberal que teve início em Sorocaba (1842). Ela está situada na periferia de Sorocaba, na rua Azevedo Figueiredo, 214, no Bairro Brigadeiro Tobias. Oferece Ensino Fundamental (Anos Iniciais), Fundamental (/Anos Finais) e Ensino Médio aos moradores da região. Sua clientela é composta por moradores do bairro citado, bem como da área rural das proximidades. 
Nesta escola foram avaliadas as Pranchas Temáticas de História ${ }^{15}$. O pedido para aplicar tais pranchas foi feito diretamente com a Coordenadora Pedagógica e com a professora Maria Cristina dos Anos Iniciais do Ensino Fundamental. Para tanto, foi apresentado um plano de trabalho para o $5^{\circ}$ ano, com o objetivo que a professora o avaliasse e apresentasse seus comentários.

Assim, foram realizadas duas reuniões no mês de agosto com a citada professora, vários contatos por e-mail e por telefone. A primeira reunião aconteceu no dia 01 de agosto de 2012. Na ocasião foi mostrado o capítulo III do protótipo do Atlas que trata da História de Sorocaba. A Prancha Temática escolhida para avaliação pela professora foi a Linha do Tempo de Sorocaba que foi aceita pela pesquisadora. Na ocasião ficou decidido que a professora se colocaria na situação de usuária crítica dessa parte do protótipo do atlas num primeiro momento, para em seguida trabalhá-las com os seus alunos. E que por fim, aplicaria um exercício envolvendo o uso da Prancha Temática: Linha do Tempo.

$\mathrm{Na}$ segunda reunião (06/08/2012), foram discutidas as atividades que deveriam ser desenvolvidas em sala de aula, bem como as datas das aplicações. Por fim, seria feita uma reunião com a professora Maria Cristina e a pesquisadora para a entrega das atividades realizadas pelos alunos do $5^{\circ}$ ano, correção e avaliação dos resultados. Assim, a avaliação das Pranchas Temáticas do Atlas contou com a colaboração de duas escolas estaduais, uma localizada mais próxima á região central e outra na periferia do Município de Sorocaba.

\footnotetext{
${ }^{15}$ A avaliação do conteúdo da História contou com a colaboração do notório conhecedor da História de Sorocaba, professor historiador Adilson Cezar, também Presidente do IHGG (Instituto Histórico, Geográfico e Genealógico) de Sorocaba/SP.
} 


\subsection{Metodologia seguida para avaliação de algumas Pranchas Temáticas do protótipo}

A organização desta metodologia foi feita mediante a estruturação de um fluxograma.

O fluxograma apresentado na figura 13 tem por objetivo demonstrar de uma forma concisa a metodologia seguida para a avaliação dos capítulos do protótipo do Atlas Escolar através de suas Pranchas Temáticas. Assim, nele é possível observar o encaminhamento seguido desde as etapas preparatórias para a aplicação das pranchas temáticas até a sua finalização.

Fluxograma da metodologia seguida para avaliação dos capítulos do Protótipo do atlas escolar

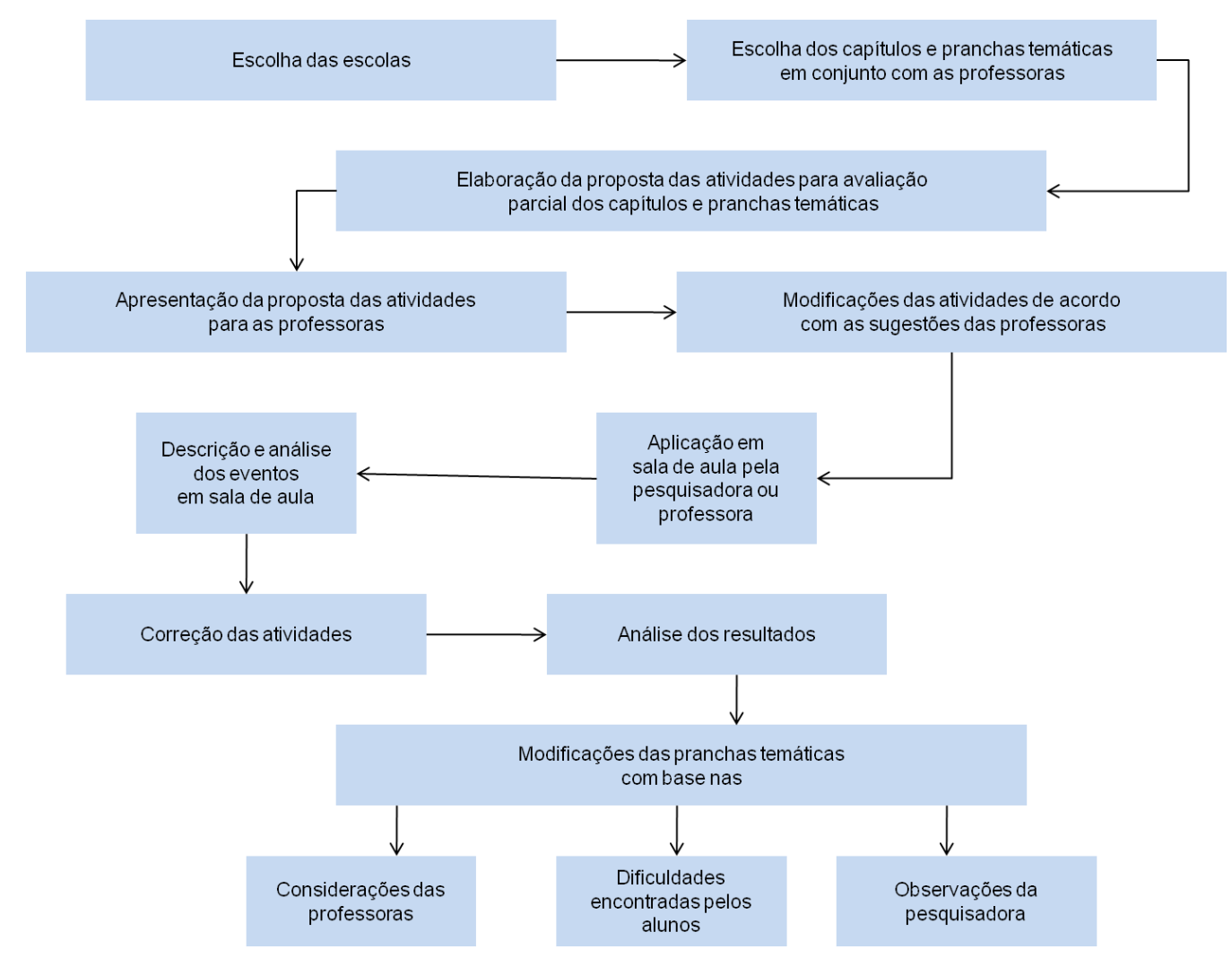

Figura 13 - O Fluxograma mostra a sequência concatenada das etapas da avaliação. Fonte: a autora. 


\subsection{As avaliações}

Para a avaliação do protótipo do Atlas, houve a colaboração de duas escolas estaduais. Na Escola Estadual Baltazar Fernandes foram avaliados parcialmente os capítulos I e II. Contou com a participação de três turmas dos $2^{\circ}$ anos, duas dos $3^{\circ}$ anos, 2 dos $5^{\circ}$ anos. Assim, neste processo estiveram envolvidas sete turmas, num total aproximado de duzentos e dez alunos e sete professoras que participaram do processo de ponderação.

A Escola Estadual Brigadeiro Tobias contribuiu nesta pesquisa através da participação na avaliação parcial do capítulo III do protótipo. Assim, contou com a colaboração de uma professora e suas três turmas de $5^{\circ}$ anos, totalizando cerca de 90 alunos.

\subsubsection{As avaliações na Escola Estadual Baltazar Fernandes}

\subsubsection{CAPÍTULO I - Ingressando no atlas}

O capítulo I - Ingressando no atlas foi dedicado à Iniciação Cartográfica. As pranchas temáticas que o compõe são:

. Apreensão e representação do espaço

. A representação da realidade espacial passo a passo

. Os elementos do mapa

. Como são feitos os mapas

. As novas tecnologias

Este capítulo foi avaliado nas turmas dos $2^{\circ}\left(A, B\right.$ e D), nos $3^{\circ}$ anos $(B, C)$ e depois nos $5^{\circ}$ anos (C, D e E).

Nos $2^{\circ}$ anos foi avaliada a Prancha Temática: Localização. A faixa etária das crianças era de 6 a 7 anos. A escolha desta prancha deu-se em função do pedido das professoras, bem como a idade cognitiva das crianças, pois nessa fase as 
crianças estão vivenciando o processo de alfabetização e, portanto, não seria possível aplicar as pranchas dos mapas temáticos.

Nos $3^{\circ}$ anos foi avaliada a Prancha Temática: Localização na sala de aula. A faixa etária das crianças envolvidas nesta avaliação era de 7 a 8 anos de idade. Elas já estavam quase todas alfabetizadas e com domínio de alguns conceitos matemáticos.

Nos $5^{\circ}$ anos este capítulo foi avaliado de uma forma diferente em relação às turmas dos $2^{\circ}$ e $3^{\circ}$ anos. A faixa etária das crianças era de 9 a 10 anos. Elas já estavam alfabetizadas e possuíam domínio de conceitos matemáticos um pouco mais adiantados. Assim, nestas turmas foram trabalhadas todas as pranchas do Capítulo I - da parte que trata da Representação da realidade espacial passo a passo e dos Elementos do mapa - através de aulas expositivas, uso de maquetes e atividades em grupo e individual.

Assim, foram elaboradas propostas de modelos de atividades para serem apresentadas às professoras dos $2^{\circ}, 3^{\circ}$ e $5^{\circ}$ Anos, com o objetivo de que elas analisassem tais propostas e sugerissem modificações. Após os devidos apontamentos nas propostas, estas passariam por uma adequação frente às reais necessidades das professoras e seus alunos.

No dia 29 de maio de 2012, ocorreu a primeira reunião com um grupo de professoras dos segundos anos: Mirian ( $2^{\circ}$. ano B), Luciana ( $2^{\circ}$. ano A), Marina (2․․ ano D). Na ocasião, foram apresentados às professoras os modelos de propostas de atividades a serem aplicados. A aprovação foi unânime com pequenas ressalvas, como a de substituir todas as palavras escritas em letra maiúscula e minúsculas por apenas letras maiúsculas para facilitar aos alunos a leitura e interpretação dos enunciados dos exercícios.

A seguir será apresentado o modelo de proposta metodológica para avaliação parcial do capítulo, propostas de atividades, alguns exemplos de atividades realizadas pelos alunos e, por fim, uma breve análise dos resultados mediante gráficos estatísticos. 


\subsection{Apreensão e representação do espaço: Localização}

Modelo da proposta metodológica para avaliação parcial do CAPÍTULO 1 INGRESSANDO NO ATLAS - PRANCHA TEMÁTICA: LOCALIZAÇÃO - 2으o, turmas: A, B e D. Escola Estadual Baltazar Fernandes.

\begin{tabular}{|c|c|c|}
\hline \multicolumn{3}{|c|}{$\begin{array}{l}\text { Proposta metodológica para avaliaç } \\
\text { ATLAS - PRANCHA TEMÁTICA: LO } \\
\text { Estadual Baltazar Fernandes. } \\
\text { Professoras: Luciana }-2^{\circ} \mathrm{A} \text { (manhã) } \\
\text { Mirian }-2^{\circ} \mathrm{B} \text { (manhã) } \\
\text { Marina- } 2^{\circ} \mathrm{D} \text { (tarde) }\end{array}$} \\
\hline Atividades & Conteúdos & O que se espera do aluno \\
\hline $\begin{array}{l}\text { Etapa I } \\
\text { Carimbo da mão } \\
\text { direita/esquerda } \\
\text {. Contorno do pé } \\
\text { direito/esquerdo }\end{array}$ & $\begin{array}{c}\text {. Lateralidade: } \\
\text { direita e esquerda }\end{array}$ & $\begin{array}{l}\text { Que o aluno confirme a sua } \\
\text { lateralidade e com a } \\
\text { participação do professor seja } \\
\text { verificado se o escolar é } \\
\text { canhoto ou destro. }\end{array}$ \\
\hline $\begin{array}{c}\text { Etapa II } \\
\text {. Mapa do corpo }\end{array}$ & $\begin{array}{c}\text {. Lateralidade } \\
\text {. Organização do espaço } \\
\text { geográfico } \\
\text { Referenciais de localização no } \\
\text { plano } \\
\text {. Localização e orientação } \\
\text { espacial }\end{array}$ & $\begin{array}{l}\text { Deseja-se que o aluno tome } \\
\text { conhecimento da sua } \\
\text { estatura, da posição de seus } \\
\text { membros, dos lados de seu } \\
\text { corpo (direito e esquerdo). } \\
\text { E quando está de frente ao } \\
\text { "mapa do corpo" (boneco), os } \\
\text { alunos consigam identificar o } \\
\text { espelhamento da lateralidade. }\end{array}$ \\
\hline $\begin{array}{c}\text { Etapa III } \\
\text {. Avaliação da } \\
\text { Prancha Temática: } \\
\text { LOCALIZAÇÃO }\end{array}$ & $\begin{array}{l}\text {. Relações espaciais } \\
\text { topológicas, projetivas na } \\
\text { prática da apreensão e } \\
\text { representação do espaço. }\end{array}$ & $\begin{array}{l}\text { Espera-se que após as } \\
\text { atividades da Etapa I e II, } \\
\text { os alunos consigam } \\
\text { responder as questões } \\
\text { solicitadas na avaliação: } \\
\text { Localizar o objeto, no caso, } \\
\text { a bola em relação a um ou } \\
\text { vários pontos e pessoas de } \\
\text { referência que não fosse a } \\
\text { própria criança. }\end{array}$ \\
\hline
\end{tabular}

Quadro 3 - Modelo da proposta metodológica para avaliação parcial do capítulo 1 Ingressando no atlas - prancha temática: localização - 2ํㅡㄹ. ano. Fonte: a autora, 2012. 


\section{ETAPA I}

A. PASSE A TINTA GUACHE VERDE NA PALMA DA SUA MÃO ESQUERDA. AGORA, CARIMBE ESSA MESMA MÃO NO ESPAÇO ABAIXO.

\section{MÃO ESQUERDA}

C. COLOQUE O SEU PÉ ESQUERDO NO QUADRO ABAIXO. FAÇA O CONTORNO DELE USANDO UM LÁPIS GRAFITE. AGORA, PINTE-O DE VERDE.
B. PASSE A TINTA GUACHE AMARELA NA PALMA DA SUA MÃO DIREITA. AGORA, CARIMBE ESSA MESMA MÃO NO ESPAÇO ABAIXO.

\section{MÃO DIREITA}

D. COLOQUE O SEU PÉ DIREITO NO QUADRO ABAIXO. FAÇA O CONTORNO DELE USANDO UM LÁPIS GRAFITE. AGORA, PINTE-O DE AMARELO.

\section{PÉ ESQUERDO}

\section{PÉ DIREITO}

Quadro 4 - Modelo da proposta das atividades para avaliação parcial do Capítulo 1 Ingressando no Atlas. Prancha Temática: Localização - 2ํano. Etapa I. Fonte: a autora, 2012. 


\section{ETAPA II}

\section{ATIVIDADE - MAPA DO CORPO}

MATERIAL A SER USADO: PAPEL PARDO, CANETAS HIDROCOR, TINTA GUACHE, LÁPIS, BORRACHA, FITA CREPE

1. FORMEM GRUPOS COM OS COLEGAS.

2. FAÇAM UMA ETIQUETA COM O NOME DA ESCOLA, PROFESSORA, DATA E OS NOMES DOS COLEGAS QUE FAZEM PARTE DO GRUPO.

3. DEM UM NOME PARA O GRUPO E DECIDAM ENTRE VOCÊS QUEM FICARÁ ENCARREGADO DE EXECUTAR AS TAREFAS ABAIXO:

4. UM ALUNO DEVE DEITAR SOBRE UMA FOLHA DE PAPEL PARDO NO CHÃO, COM OS PÉS VIRADOS PARA FORA. OUTRO ALUNO FARÁ O CONTORNO DO SEU CORPO, INCLUSIVE DO CABELO. FICARÁ PARECENDO UM BONECO OU BONECA.

5. AGORA, DESENHEM O ROSTO QUE VOCÊS VERIAM NO ESPELHO.

6. DESENHEM E PINTEM O UNIFORME ESCOLAR DO BONECO OU BONECA.

7. FIXEM O BONECO OU BONECA NA PAREDE NA LOUSA.

OBS: A ATIVIDADE FOI ENCERRADA COM UMA GINCANA QUE ENVOLVEU QUATRO GRUPOS, CADA UM COM O SEU BONECO. FOI SOLICITADO UM REPRESENTANTE DE CADA GRUPO QUE DEVERIA, EM ACORDO COM O SEU GRUPO, COLOCAR ACESSÓRIOS (MEIAS, TÊNIS, RELÓGIO, BOLSO E O EMBLEMA DA ESCOLA NA CAMISETA) NOS BONECOS NO LUGAR INDICADOS PELA PESQUISADORA. POR EXEMPLO, UMA DAS SOLICITAÇÕES FOI QUE O EMBLEMA DA ESCOLA FOSSE COLOCADO NO LADO DIREITO DO BONECO.

Quadro 5 - Modelo da proposta das atividades para avaliação parcial do Capítulo 1 - Ingressando no Atlas. Prancha Temática: Localização - 2oano. Etapa II. Fonte: a autora, 2012. 


\section{ETAPA III}

\section{Avaliação da Prancha Temática: Localização}

ATIVIDADE: AJUDE O GAROTO ABAIXO A LOCALIZAR A BOLA DELE. PARA ISSO, COMPLETE COM A PALAVRA DIREITA OU ESQUERDA.

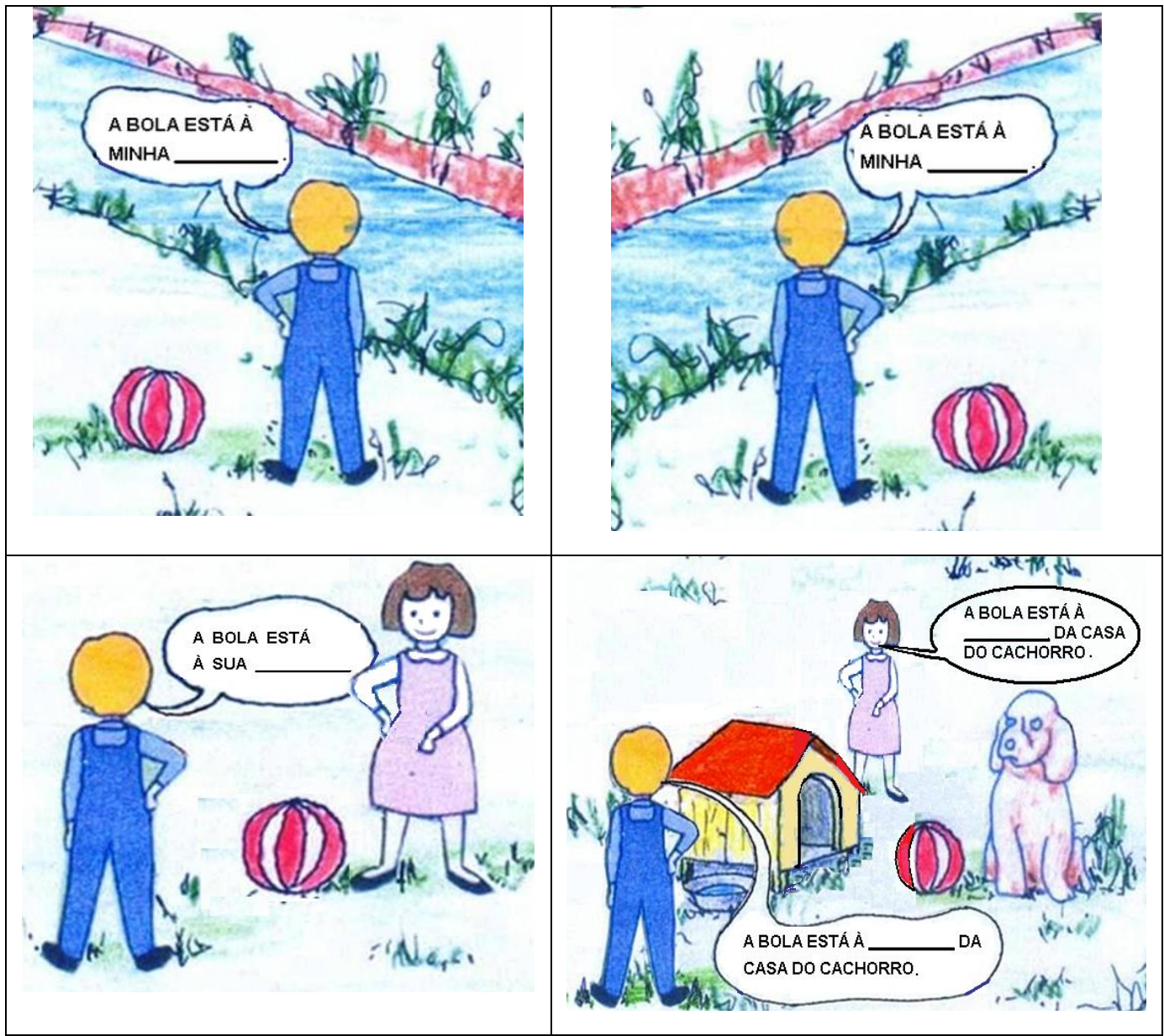

Quadro 6 - Modelo da proposta das atividades para avaliação parcial do Capítulo 1 - Ingressando no Atlas. Prancha Temática: Localização - $2^{\circ}$ ano. Etapa III. Fonte: a autora. 


\section{Apresentação das atividades executadas pelos alunos}

Etapa I. Carimbo da mão esquerda na cor verde e da mão direita na cor azul. Contorno do pé esquerdo na cor verde e do direito na cor azul. As cores foram escolhidas através de uma votação entre os alunos.

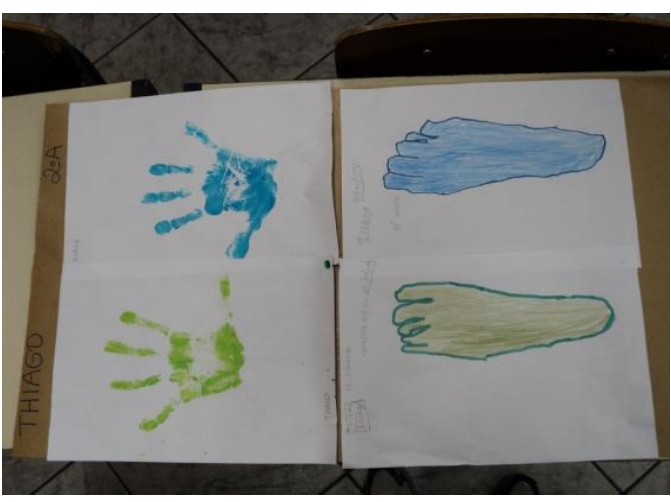

(a)

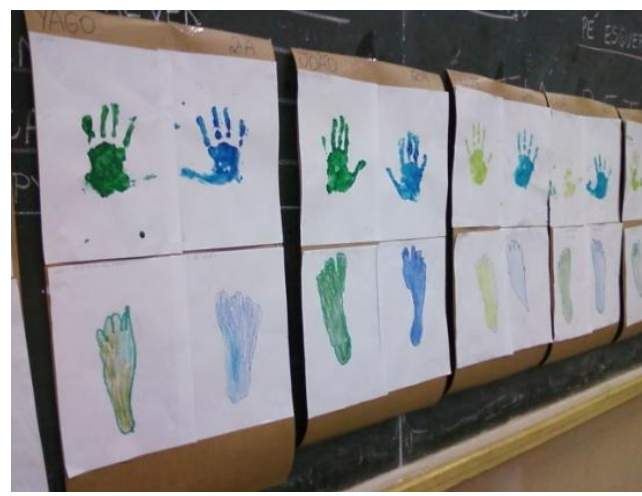

(b)

Figura 14 - Atividade: Lateralidade (a) e (b). Carimbo da mão esquerda e da direita; do pé esquerdo e do direito. Alunos do $2^{\circ}$ ano, turma "A". Fonte: a autora.

A princípio, o trabalho desenvolvido com as turmas $2^{\circ} \mathrm{A}, 2^{\circ} \mathrm{B}$ e $2^{\circ} \mathrm{D}$, seria realizado com a mesma metodologia e recursos didáticos. Entretanto, após as intervenções e resultados das atividades da primeira turma ( $2^{\circ}$. B), percebeu-se a necessidade de se readequar tanto a metodologia quanto a forma do exercício aplicado para o $2^{\circ} \mathrm{A}$, acontecendo o mesmo com a passagem do $2^{\circ} \mathrm{A}$ para $\circ 2^{\circ} \mathrm{D}$.

De maneira análoga, o mesmo ocorreu com as avaliações que serviram de diagnóstico para buscar novas formas de viabilizar o conhecimento dos alunos. Assim, um professor na condição de mediador do conhecimento, deve estar sempre aprendendo com os alunos novas formas de mediar o conhecimento. Desta forma, foram feitas três intervenções em dias seguidos com cada turma, sendo que cada uma das intervenções durou cerca de 2 horas, totalizando um trabalho de 6 horas para cada turma. As professoras auxiliaram na organização e no controle frequente do comportamento da turma, buscando relacionar o que estava sendo discutido em sala com o conteúdo de Matemática. 
A Etapa I consistia na atividade de carimbar papéis com as palmas das mãos, sendo a esquerda, pintada na cor verde, e a direita, na cor azul. Além disso, o contorno do pé esquerdo seria registrado na cor verde, enquanto que o direito, na cor azul. Contudo, antes de se iniciar esta Etapa, foi perguntado às crianças se saberiam identificar qual era a sua mão direita ou esquerda. As crianças ficaram confusas, algumas acertaram, mas a maioria errou. Quando foi pedido para mostrarem o seu pé direito, as crianças foram surpreendidas, pois já haviam ouvido falar da mão direita ou esquerda, mas nunca haviam pensando em pé direito ou esquerdo. Então, foi esclarecido a elas que temos um lado do corpo denominado direito (mão, olho, orelha, perna, pé) e outro esquerdo (mão, olho, orelha, perna, pé). A professora aproveitou o momento para trabalhar e correlacionar os números pares e os ímpares, com os dois olhos que eles tinham (número par), com um nariz (número ímpar) etc. Neste momento, ficou claro que uma atividade posterior envolvendo o "mapa do corpo" seria bem vinda.

Após a turma entrar em acordo quanto à lateralidade do corpo humano partindo delas mesmas, começou-se a aplicação pelo carimbo da mão esquerda por ser o mais fácil, uma vez que para pintar a palma da mão esquerda foi usada a mão direita, isto para o caso dos destros. Este momento foi sentido pelas crianças como uma atividade prazerosa, pois ela se deu no pátio da escola e estavam trabalhando com tinta. Assim, carimbaram a mão esquerda na cor verde e a mão direita na cor azul, usando tinta guache. Entretanto, alguns alunos do $2^{\circ} \mathrm{A}$, após 0 desenvolvimento desta atividade demonstraram extrema preocupação com a tinta na palma da mão, algumas choraram, tiveram medo da tinta nunca sair das mãos, da reação das mães, avós, responsáveis, etc.

Diante desta situação, foi explicado aos alunos que a tinta que estava na palma das suas mãos era à base de água, de forma que não teriam grandes dificuldades em higienizá-las. Neste momento, a própria professora destacou que este fato não deveria ter acontecido, tendo em vista que frequentavam as aula de Artes e que eram crianças de apenas 7 anos. Como tentativa de justificar tal fato, a professora comentou que vários alunos manifestavam problemas emocionais em função de alguns fatores, como pais que se drogavam, de forma que muitos 
estavam aos cuidados de suas avós, ou ainda apresentavam estado de hiperatividade.

Carimbadas as duas palmas das mãos das crianças em um papel sulfite formato A4, perguntou-se à turma: "O que vocês estão fazendo?" A resposta de um dos alunos do $2^{\circ} D$ foi: "Pintamos a mão esquerda de verde e colocamos ela no papel pra gente não esquecer qual é a mão esquerda. Pintamos a outra que é a direita de azul, pra gente guardar bem qual é a nossa mão direita". Uma aluna completou dizendo "ficou uma cor diferente pra cada mão, porque temos uma mão direita e outra esquerda". Essa questão foi dada para as três turmas $2^{\circ} \mathrm{A}, \mathrm{B}$ e $\mathrm{D}$ e a resposta foi praticamente a mesma para as demais turmas.

Terminada essa parte da atividade, todos os alunos voltaram para a sala de aula. Foi pedido aos alunos para tirarem os sapatos e as meias para realizarem a atividade do contorno dos pés. Novamente, os alunos do $2^{\circ}$ A manifestaram resistência para a solicitação, pois alegaram que iam sujar os pés, perder as meias etc. Notou-se que os alunos que demonstraram resistência vestiam meias velhas ou sujas, e tais fatos eram comentados em voz alta pelos próprios colegas, causando assim, um certo constrangimento. Porém, ao comando da professora, todos tiraram seus sapatos e começaram a fazer o contorno dos pés, usando um lápis de escrever. Neste momento, perguntou-se à turma qual cor eles usariam para pintar o contorno do pé esquerdo. A resposta foi unânime: "a cor verde, porque foi essa cor usada para a mão esquerda". O mesmo foi feito para a o contorno do pé direito. Nas demais turmas os alunos não tiveram problemas em tirar os tênis e meias para realizarem o contorno dos pés.

Por fim, foi distribuído um pedaço de papel pardo no tamanho aproximado de um A-3 para que cada aluno o dividisse ao meio, estabelecesse o lado direito e o esquerdo do papel, escrevesse o seu nome e o afixasse na lousa. Em seguida, foi solicitado a cada aluno para que se levantasse, se dirigisse à lousa e afixasse o carimbo da sua mão esquerda e pé esquerdo no lado esquerdo do papel pardo, fazendo o mesmo com a mão direita e o pé direito no lado direito do papel pardo. Desejava-se com isso que as crianças percebessem que da mesma forma que para o corpo humano foi determinado um lado direito e um esquerdo, o mesmo foi feito 
para os objetos, no caso, o papel pardo. Dessa forma, deu-se por finalizada a primeira Etapa das intervenções.

Etapa II. Mapa do corpo da criança.

Nesta atividade, foi trabalhado o corpo da criança, destacando a sua simetria e a identificação dos lados direito e esquerdo. O objetivo dessa atividade era levar o aluno a aprender a noção de lateralização e comprovar sua lateralidade, representando no papel, os conhecimentos adquiridos através de suas próprias observações, bem como as dos colegas integrantes do grupo.

Todas as crianças demonstraram muito interesse em mapear o corpo do colega. Assim, para todas as turmas ficou estabelecido que o trabalho com o Mapa do Corpo seria realizado em grupos de no máximo 5 crianças, o que resultaria para cada turma na confecção de 4 Mapas do Corpo ou 4 Bonecos, como os chamaram as crianças. Este momento foi tranquilo para todas as turmas, havendo apenas algumas disputas como quem seria o modelo, pois os traços faciais e o cabelo seriam determinados em função do modelo. Na figura 15 se tem os bonecos prontos, sem acessórios.

Antes, porém, foi pedido aos alunos para que observassem que o boneco à sua frente, apresentava-se como num espelho. Assim, foi pedido para que dois alunos se levantassem e observassem um ao outro; depois, que ambos levantassem ao mesmo tempo a mão esquerda e, em seguida, fizessem o mesmo com a direita. Desta forma, em pouco tempo, os alunos perceberam que esta situação era exatamente a mesma daquela de se encontrar em frente ao boneco afixado na lousa.

Como não foi feito o boneco de costas, foi solicitado aos alunos para que um aluno ficasse de costas para o outro na frente da lousa, de forma que todos os alunos percebessem que nessa situação, a posição da mão direita de um dos alunos correspondia exatamente à mesma posição da mão direita do colega. 
Após essa etapa, realizou-se uma gincana como pretexto para trabalhar a lateralidade e descentralização. As tarefas da gincana estavam associadas à colocação de objetos nos bonecos, conforme orientação do pesquisador. Os objetos a serem colocados nos bonecos eram: relógio, meias, tênis, bolsos e o emblema da escola na camiseta. Durante a gincana, era solicitado para que um integrante de cada grupo se posicionasse frente ao boneco feito pelo seu corpo, para que posicionasse os objetos nos lugares corretos conforme a solicitação do pesquisador. Por exemplo, "coloque o relógio no pulso esquerdo do boneco", "observe o emblema da escola na sua camiseta", ou "coloque o emblema na camiseta do boneco". Após a execução das tarefas, era atribuída uma pontuação para os acertos.

Em seguida, era solicitado para que outro integrante de cada grupo se posicionasse para também colocar um objeto no boneco no lugar correto. Desta forma, todos os integrantes dos grupos tiveram a oportunidade de participar desta atividade. Por fim, considerou-se que os resultados alcançados foram positivos, de uma maneira geral, para todos os grupos das turmas do $2^{\circ}$ A, B e D.

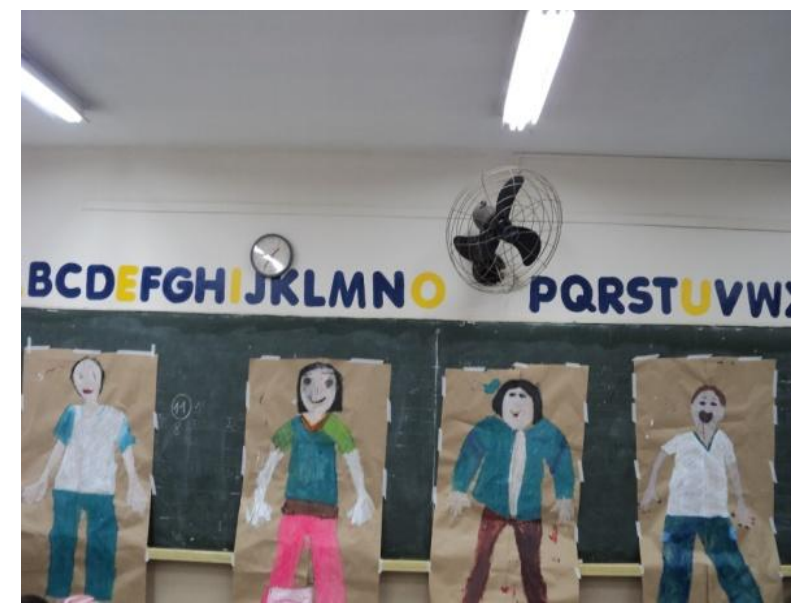

(a)

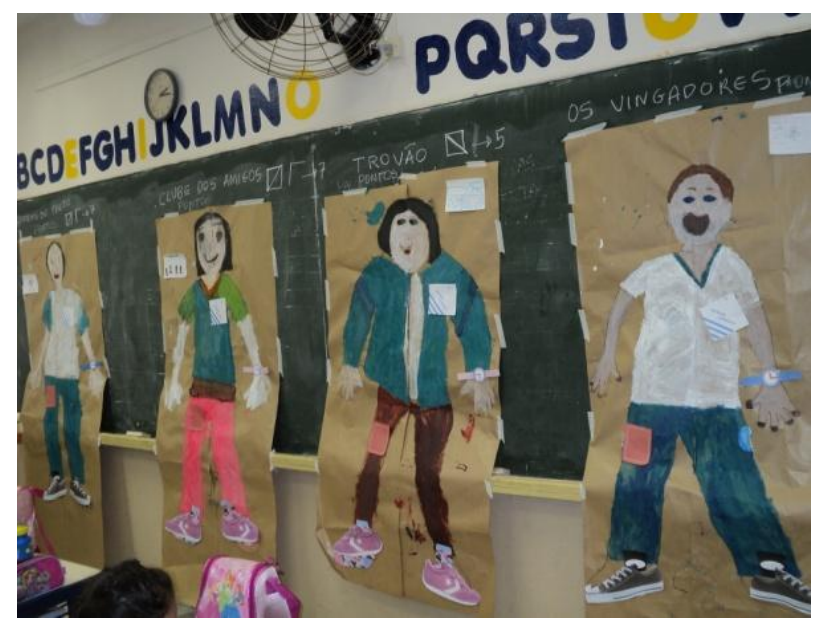

(b)

Figura 15 - Mapa do corpo da criança (a) e (b). Atividade desenvolvida pelos alunos do $2^{\circ}$ ano, turma "A". Fonte: a autora. 
Etapa III. Avaliação da Prancha Temática: Localização

A avaliação da Prancha Temática foi feita de forma individual, onde cada aluno teve a oportunidade de responder às questões apresentadas segundo o seu conhecimento. $\mathrm{Na}$ oportunidade, foi retomado que a posição de qualquer objeto no espaço é definida com base a um ponto de referência, um referencial. Assim, é importante que os alunos sempre façam a pergunta: a posição de algo ou alguém se dá em relação a quê ou quem? Esse conhecimento é importante para a compreensão das representações, em que as posições, "direita e esquerda" se invertem em relação ao próprio corpo do leitor. Desta forma, experimentaram-se as relações espaciais projetivas.

A figura abaixo é um exemplo do resultado da aplicação da prancha com o aluno Guilherme do $2^{\circ} \mathrm{A}$, da professora Marina. Uma vez recolhidas estas atividades dos alunos, foram identificados os erros e os acertos em cada uma delas e, a seguir, foram construídos gráficos para representar os resultados obtidos e uma tabela para demonstrar o que foi alterado na Prancha Temática do Atlas: Localização. 


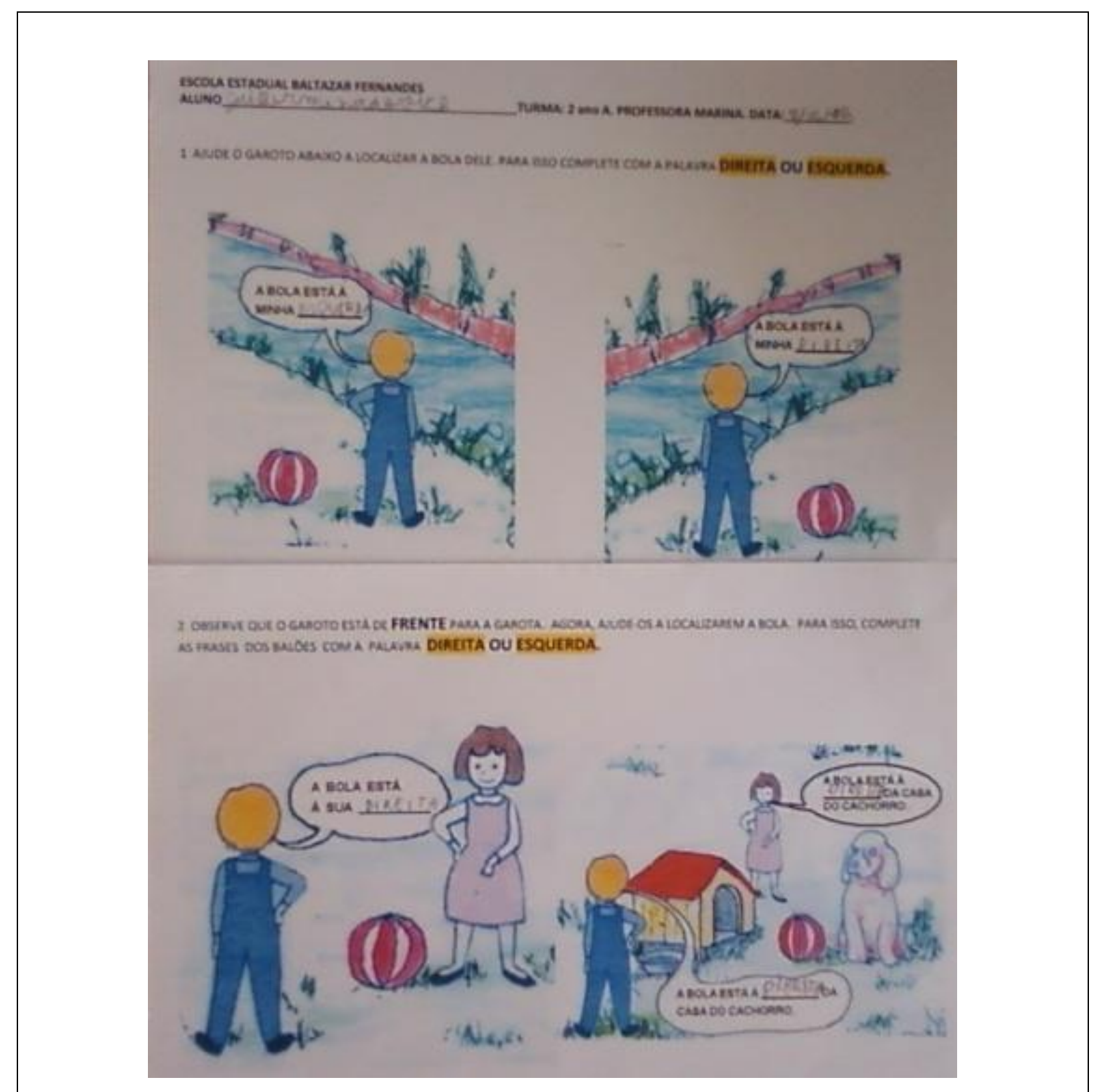

Quadro 7 - Exemplo da Avaliação realizada. Capítulo 1 - Ingressando no Atlas. Prancha Temática: Localização. $2^{\circ}$ ano, turma "A". Fonte: a autora, 2012.

Análise dos Resultados da Avaliação da Prancha Temática: LOCALIZAÇÃO - 2oㅜ ano, turmas A, B e D

Nesta avaliação, os gráficos 1, 2 e 3 correspondem ao percentual de alunos das turmas dos 2os. anos $A, B$ e $D$, respectivamente, em função do número de questões corretamente respondidas por eles. Estas turmas A, B e D possuíam 15, 17 e 19 alunos, respectivamente. Esperava-se com essas atividades que os alunos 
localizassem o objeto, no caso, a bola em relação a um ou vários pontos de referência que não fosse a própria criança.

Gráfico 1

PERCENTUAL DOS ALUNOS DA TURMA DO 2응 ANO A, SEGUNDO O NÚMERO DE QUESTÕES CERTAS. PRANCHA TEMÁTICA: LOCALIZAÇÃO - 2012

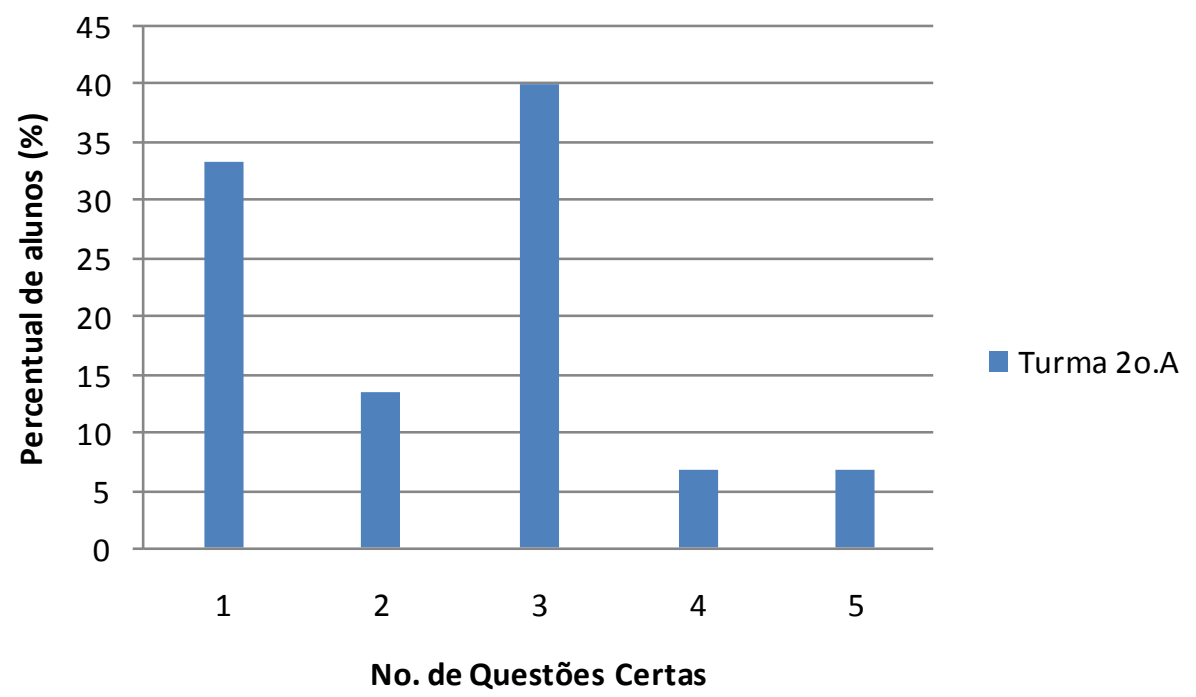

Fonte: a autora, 2012.

Gráfico 2

PERCENTUAL DOS ALUNOS DA TURMA DO $2^{\circ}$ ANO B, SEGUNDO O NÚMERO DE QUESTÕES CERTAS. PRANCHA TEMÁTICA: LOCALIZAÇÃO - 2012

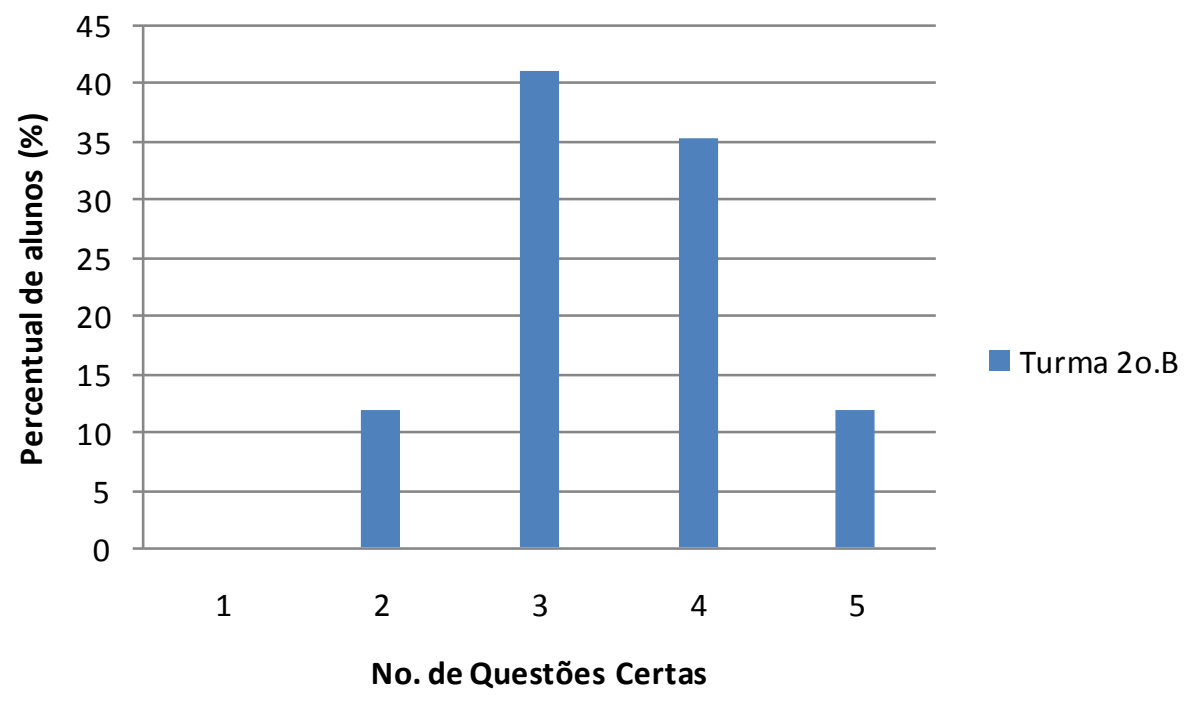


Gráfico 3

PERCENTUAL DOS ALUNOS DA TURMA DO 2 ANO D, SEGUNDO O NÚMERO DE QUESTÕES CERTAS. PRANCHA TEMÁTICA: LOCALIZAÇÃO - 2012

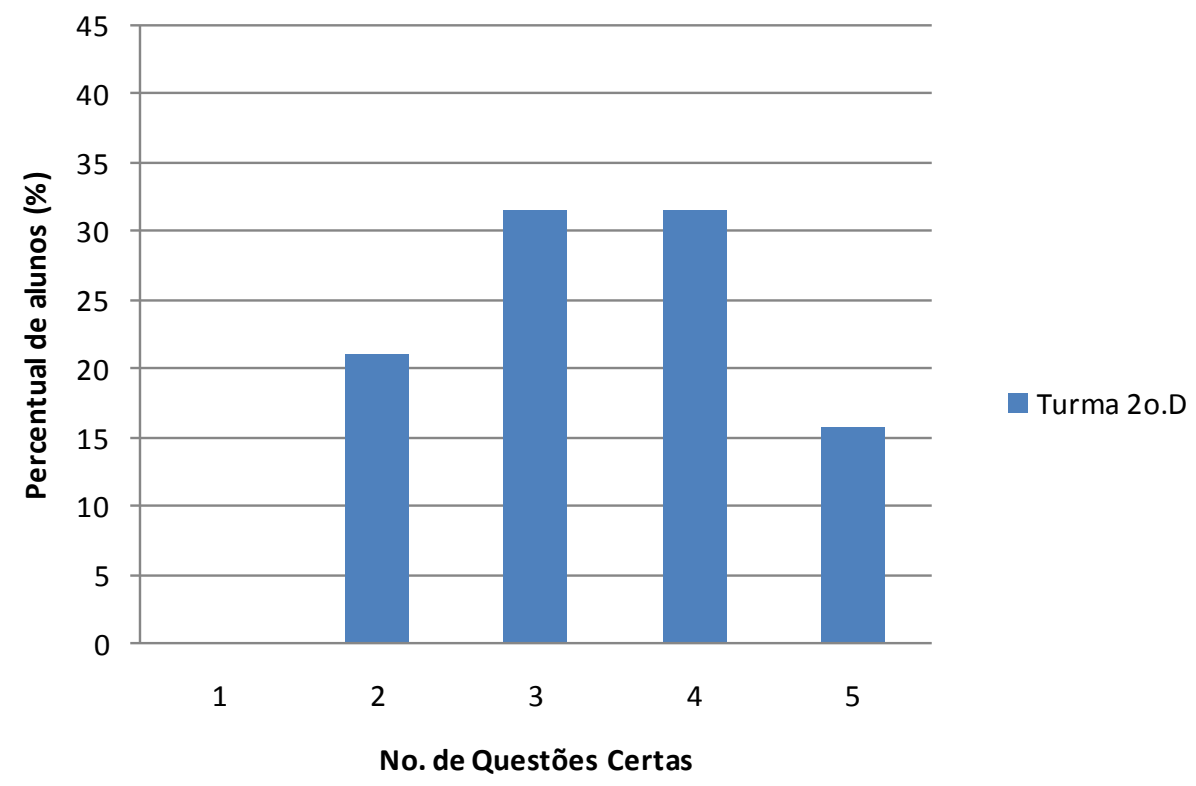

Fonte: a autora, 2012.

Da análise dos gráficos 1, 2 e 3, nota-se que as turmas B e D alcançaram um desempenho semelhante e superior à turma $A$, respondendo a mais da metade do número de questões apresentadas de forma correta. Este desempenho justifica-se pelo fato de que alunos das turmas B e D demonstraram maior estabilidade emocional do que os alunos da turma A. Durante a execução das atividades, por exemplo, os alunos da turma $A$ aceitaram com muita relutância atividades comuns com crianças como pintar as mãos com tinta lavável ou retirar os calçados. Além disso, pela observação do engajamento dos alunos em cada turma, esperava-se que a turma $\mathrm{D}$ apresentasse um melhor desempenho em relação às demais, o que não foi revelado pelos gráficos anteriores. Contudo, deve-se ressalvar que na turma $D$ havia 2 alunos que ainda não estavam alfabetizados.

A seguir, o gráfico n. 4 corresponde ao percentual de alunos de todas as turmas dos 2os. anos, segundo o número de questões corretamente respondidas por eles, podendo fornecer uma visão de conjunto. A partir deste gráfico, é possível perceber que há uma distribuição ligeiramente assimétrica do percentual de alunos 
em função do número de questões certas, indicando que a maioria dos alunos acertou mais da metade das questões propostas.

Gráfico 4

PERCENTUAL DOS ALUNOS DE TODAS AS TURMAS DOS 2 ANOS, SEGUNDO O NÚMERO DE QUESTÕES CERTAS. PRANCHA TEMÁTICA: LOCALIZAÇÃO - 2012

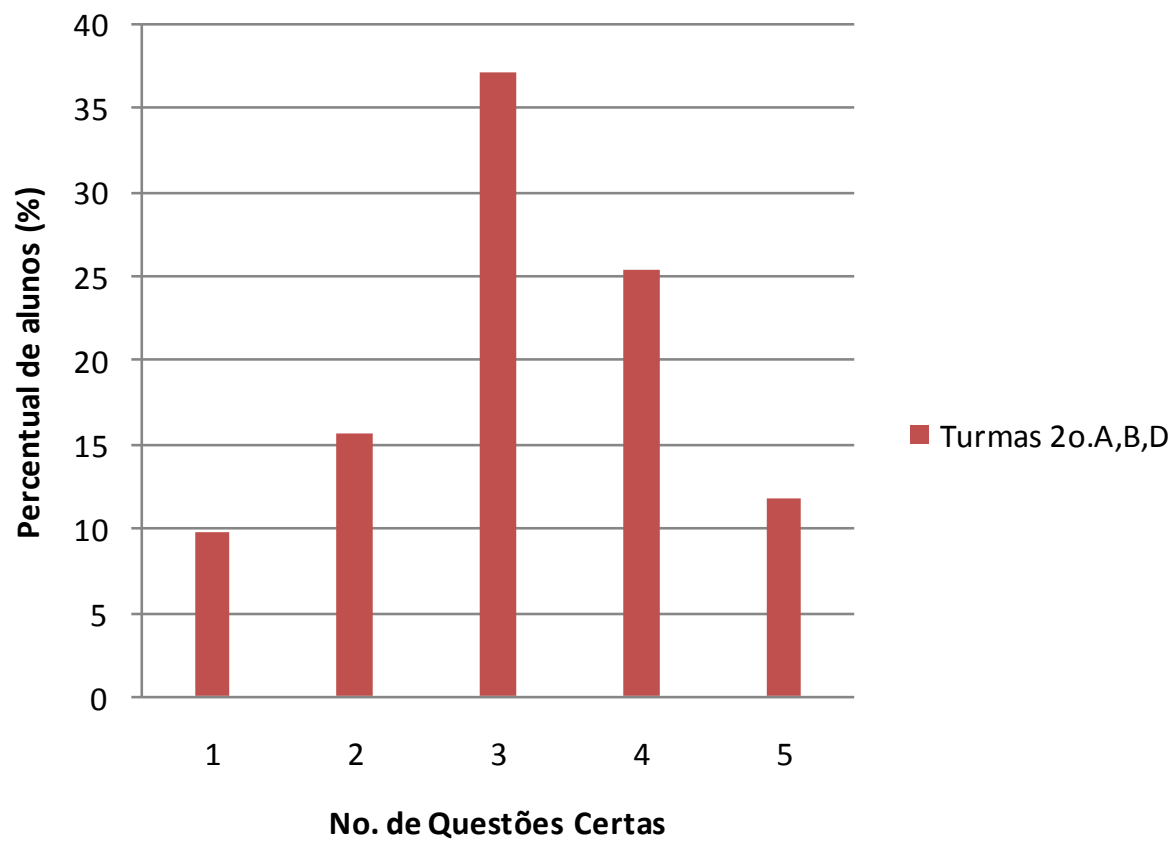

Fonte: a autora, 2012. 


\subsection{Apreensão e representação do espaço - Coordenadas Geográficas: Localização na sala de aula}

\section{Modelo da proposta metodológica para avaliação parcial do CAPÍTULO 1 - INGRESSANDO NO ATLAS - PRANCHA TEMÁTICA: LOCALIZAÇÃO NA SALA DE AULA - 3a ano, turmas: B e C.}

Após a finalização do trabalho com as professoras dos 20 Anos foi comunicado à Direção da Escola, o término desta etapa e o início do trabalho com os alunos dos $3^{\circ}$ Anos.

Assim, foi agendada uma reunião com o grupo de quatro professoras: Rose Helena ( $\left.3^{\circ} \mathrm{A}\right)$, Adriana $\left(3^{\circ} \mathrm{B}\right)$, Fernanda $\left(3^{\circ} \mathrm{C}\right)$ e Paula Pontes $\left(3^{\circ} \mathrm{C}\right)$ para o dia 19 de junho de 2012, durante a HTPC. Entretanto, a reunião foi cancelada pela Direção, de forma que dada a proximidade do período das férias escolares, a comunicação deuse através de e-mails e telefone. Assim, foi enviado um e-mail para cada professora do grupo contendo uma proposta de trabalho, ou seja, a apresentação da atividade e dos conhecimentos relativos à representação do espaço. As professoras analisaram o material e o aprovaram sem nenhuma ressalva.

Outro ponto que ficou acertado com as professoras foi a otimização do tempo, pois restavam apenas a duas semanas para o início das férias escolares e a Escola estava também se preparando para a avaliação do SARESP. Desta forma, dispunha-se apenas da última semana do mês de junho para trabalhar com quatro turmas, duas do período da manhã e duas da tarde. Assim, as professoras sugeriram que o trabalho fosse desenvolvido com apenas 2 turmas, no caso o $3^{\circ}$. B e o 3 . C. Assim, as professoras destas turmas se comprometeram a repassar o que fosse desenvolvido em sala com os seus alunos para as demais professoras.

A seguir será apresentado o modelo de propostas de atividades, exemplos de atividades desenvolvidas por alunos e por último, a análise dos resultados. 


\begin{tabular}{|c|c|c|}
\hline \multicolumn{3}{|c|}{$\begin{array}{l}\text { Proposta metodológica para avaliação parcial do CAPÍTULO } 1 \text { - } \\
\text { INGRESSANDO NO ATLAS - PRANCHA TEMÁTICA: LOCALIZAÇÃO NA SALA } \\
\text { DE AULA - } 3^{\circ} \text { ano, turmas: B e C. Escola Estadual Baltazar Fernandes. }\end{array}$} \\
\hline \multicolumn{3}{|c|}{$\begin{array}{l}\text { Professoras: } \begin{aligned} \text { Rose Helena }-3^{\circ} \mathrm{A}(\text { manhã }) \\
\text { Adriana }-3^{\circ} \mathrm{B}^{*}(\text { tarde }) \\
\text { Paula }-3^{\circ} \mathrm{C}^{*}(\text { tarde }) \\
\text { Fernanda }-3^{\circ} \mathrm{E}(\text { tarde })\end{aligned}\end{array}$} \\
\hline Atividades & Conteúdos & $\begin{array}{c}\text { O que se espera do } \\
\text { aluno }\end{array}$ \\
\hline $\begin{array}{l}\text { I Etapa } \\
\text { Coleta de dados } \\
\text { sobre os objetos } \\
\text { da sala de aula } \\
\text { para a construção } \\
\text { de uma maquete }\end{array}$ & $\begin{array}{c}\text { Observação e identificação } \\
\text { dos objetos em sala de aula } \\
\text {.Desenvolvimento de } \\
\text { equivalentes } \\
\text { tridimensionais } \\
\text { Coordenação de diferentes } \\
\text { pontos de vista }\end{array}$ & $\begin{array}{l}\text { Que o aluno ao coletar os } \\
\text { dados da sala de aula, } \\
\text { estabeleça uma relação de } \\
\text { proporção de tamanho entre } \\
\text { os objetos reais e as sucatas } \\
\text { que serão usadas na maquete. } \\
\text { E que ele consiga determinar } \\
\text { a localização de objetos e de } \\
\text { colegas em função dos pontos } \\
\text { de referência. }\end{array}$ \\
\hline $\begin{array}{l}\text { Il Etapa } \\
\text { Desenho da planta } \\
\text { baixa da maquete } \\
\text { da sala de aula no } \\
\text { celofane }\end{array}$ & $\begin{array}{c}\text {. Visão vertical de cima } \\
\text { para baixo } \\
\text {.Coordenação de diferentes } \\
\text { pontos de vista } \\
\text {.Legenda } \\
\text {.Projeção ortogonal a partir } \\
\text { do ponto de vista vertical }\end{array}$ & $\begin{array}{l}\text { Vislumbra-se que o aluno } \\
\text { tenha assimilado a } \\
\text { operacionalização } r \text { da } \\
\text { passagem de uma } \\
\text { realidade tridimensional } \\
\text { para uma representação no } \\
\text { plano em duas dimensões. }\end{array}$ \\
\hline $\begin{array}{l}\text { Ill Etapa } \\
\text { Aplicação da } \\
\text { Prancha Temática: } \\
\text { Localização na } \\
\text { sala de aula }\end{array}$ & . Avaliação do resultado & $\begin{array}{l}\text { Após a passagem pelas } \\
\text { etapas I e II, há a } \\
\text { expectativa de que o aluno } \\
\text { desenvolva a compreensão } \\
\text { necessária para resolver as } \\
\text { atividades estipuladas na } \\
\text { avaliação. }\end{array}$ \\
\hline
\end{tabular}

Quadro 8 - Modelo da proposta metodológica para avaliação parcial do capítulo 1 - Ingressando no atlas - prancha temática: localização na sala de aula - 3ํano, turmas: "B" e "c". Fonte: a autora, 2012. 


\section{ETAPA I}

Coleta de dados dos objetos da sala de aula para a construção de uma Maquete

1. Observem a sala de aula. Agora registrem na tabela a quantidade dos itens indicados. (Obs.: A tabela deve ser reproduzida na lousa).

Tabela: Coleta de dados dos objetos da sala de aula

\begin{tabular}{|c|c|c|c|}
\hline $\begin{array}{c}\text { OBJETOS DA } \\
\text { SALA DE AULA }\end{array}$ & QUANTIDADE & $\begin{array}{c}\text { OBJETOS DA SALA DE } \\
\text { AULA }\end{array}$ & QUANTIDADE \\
\hline PLANISFÉRIO & & LOUSA & \\
\hline ALUNOS & & MESA DOS ALUNOS & \\
\hline ARMÁRIOS & & LIXEIRA & \\
\hline PROFESSORA & & MESA DA PROFESSORA & \\
\hline JANELAS & & PORTA & \\
\hline
\end{tabular}

Obs.: Após a coleta de dados, solicitar aos alunos sucatas para a construção da Maquete da Sala de Aula. As sucatas devem ser escolhidas de forma que tenham um formato parecido com os objetos da sala de aula, também devem ser proporcionais ao objeto a ser representado. Esta atividade será desenvolvida em grupo.

2. Construção da Maquete da sala de aula usando sucatas

- 1 caixa de papelão com o formato próximo ao da sala de aula, caixas de fósforos pequenas para representar as carteiras dos alunos, embalagens de brigadeiro para representar os alunos, 1 caixa de fósforos grande para fazer a mesa do professor e uma tampinha pet para a professora, 1 folha de celofane transparente, 1 caneta de tinta permanente preta para marcar o celofane, caixas pequenas para representar os armários, 1 sucata que represente a lixeira, tinta guache, 1 cola Tenaz, 10 folhas de papel sulfite, 1 tesoura sem ponta, fita adesiva e canetinhas hidrocor.

Quadro 9 - Modelo da proposta das atividades para avaliação parcial do Capítulo 1 - Ingressando no Atlas. Prancha Temática: Localização na sala de aula - 3ำ ano. Etapa I. Fonte: a autora, 2012. 


\section{ETAPA II}

Projeção da maquete da sala de aula no celofane

Após a representação da sala de aula por meio de uma maquete, os alunos irão projetar a maquete no celofane, olhando-a de cima para baixo (visão vertical), ou seja, farão o contorno dos objetos que estão dentro da maquete. Nesse momento, o escolar terá feito o desenho da planta baixa da sua sala de aula.

$\checkmark$ Feita a Planta da Sala de Aula, será colocada aos alunos uma "situação-problema": Se vocês mostrarem o desenho da Planta da sala de aula para outras pessoas, será que elas vão conseguir entendê-lo? Nesse momento, espera-se que os alunos sugiram a criação de um código. Será introduzida, assim, a ideia de Legenda.

Quadro 10 - Modelo da proposta das atividades para avaliação parcial do Capítulo 1 - Ingressando no Atlas. Prancha Temática: Localização na sala de aula - 3ํao. Etapa II. Fonte: a autora, 2012. 


\section{ETAPA III - primeira parte}

Avaliação da Prancha Temática : Localização na sala de aula Escola Estadual Baltazar Fernandes

Professora:

Nome: . 3ำ Ano . Data:

\section{ATIVIDADE INDIVIDUAL}

1. Quantas carteiras há em cada coluna? (coluna= uma carteira atrás da outra)

2. Quantas carteiras há em cada fileira? (fileira = uma carteira ao lado da outra)

3. Você está no fundo da Sala de aula, olhando para a lousa. Agora, resolva as questões abaixo:

3.1 Marque um $\mathbf{X}$ onde está a mesa do professor.

Em frente às carteiras, no canto direito da sala. ( )

Em frente às carteiras, no canto esquerdo da sala. ( )

3.2 Marque um $\mathbf{X}$ onde fica a porta?

Na parede, à esquerda das carteiras ( )

Na parede, à direita das carteiras ( )

3.3 Marque um $\mathbf{X}$ onde fica a janela?

Na parede, à esquerda das carteiras （ )

Na parede, à direita das carteiras ( )

Na parede, atrás das carteiras ( )

Quadro 11 - Modelo da proposta das atividades para avaliação parcial do Capítulo 1 - Ingressando no Atlas. Prancha Temática: Localização na sala de aula - 3ํano. Etapa III - Primeira Parte. Fonte: a autora, 2012. 


\section{ETAPA III - segunda parte}

Abaixo você tem a Planta Baixa de outra sala de aula. Localize em qual carteira o aluno "A" está sentado em relação às linhas, azul e vermelha, riscadas no chão?

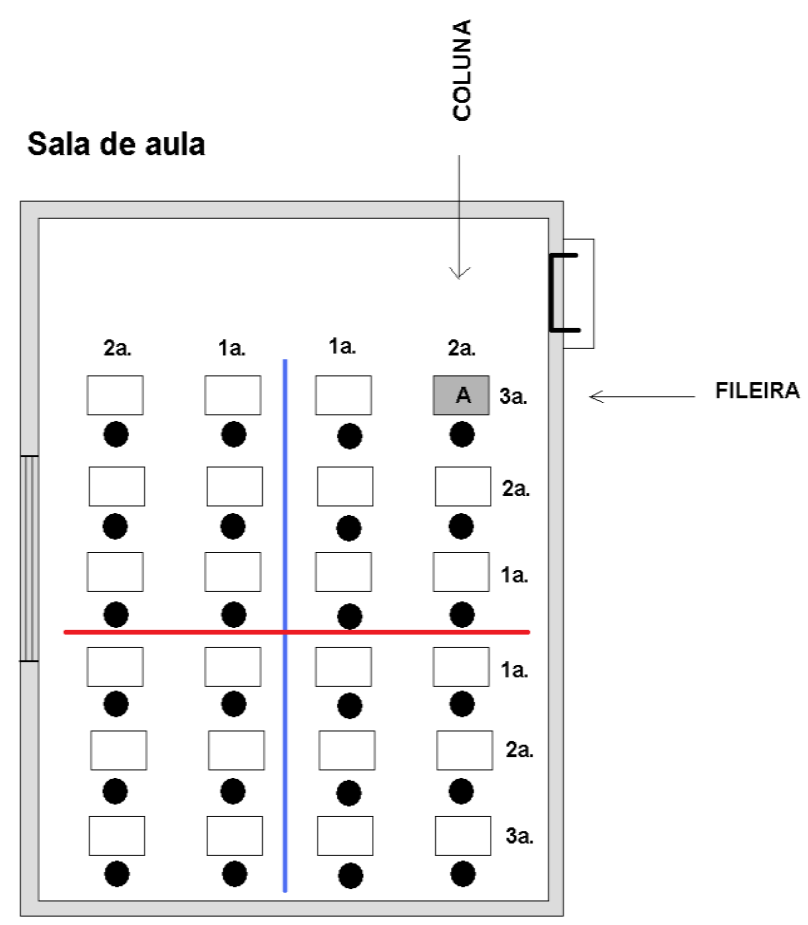

Agora, marque um $\mathrm{X}$ na resposta correta

( ) O aluno "A" está sentado na carteira da segunda coluna à direita da linha AZUL, cruzando com a terceira fileira à frente da linha VERMELHA.

( ) O aluno "A" está sentado na carteira da segunda coluna à esquerda da linha AZUL, cruzando com a terceira fileira à frente da linha VERMELHA.

Quadro 12 - Modelo da proposta das atividades para avaliação parcial do Capítulo 1 - Ingressando no Atlas. Prancha Temática: Localização na sala de aula - $3^{\circ}$ ano. Etapa III - Segunda Parte. Fonte: a autora, 2012. 


\section{Apresentação das atividades executadas pelos alunos}

Etapa I. Coleta de dados dos objetos da sala de aula para a construção de uma Maquete

As professoras entregaram aos alunos uma tabela, para que estes observassem a sala de aula e registrassem a quantidade dos itens solicitados. Esta atividade teve a supervisão apenas da professora sem a presença da pesquisadora. Esta coleta de dados foi importante para ajudar na escolha do material adequado e em número suficiente para a confecção da maquete da sala de aula. A seguir, apresenta-se, a título de exemplo, uma tabela preenchida por um aluno.

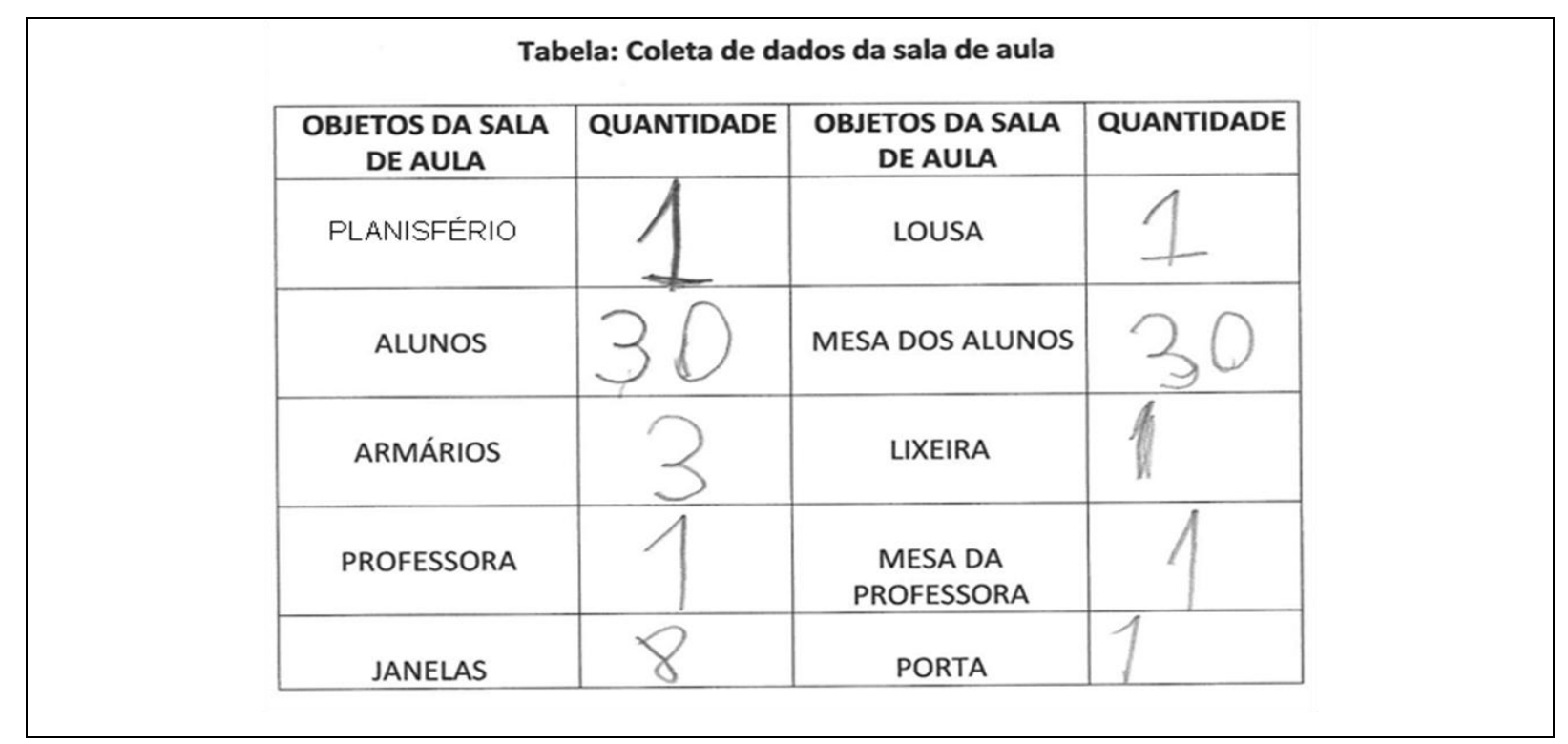

Quadro 13 - Exemplo da atividade realizada. Capítulo 1 - Ingressando no Atlas. Prancha Temática Localização na sala de aula. Exercício - "coleta de dados da sala de aula". $3^{\circ}$ ano, turma "C". Fonte: a autora, 2012.

$\mathrm{Na}$ aula seguinte, todos os alunos estavam com a sua tabela preenchida e demonstraram domínio acerca da quantidade dos objetos na sala de aula. Uma vez concluída a primeira etapa, os alunos foram instruídos de que iriam construir uma maquete da sala de aula. Assim, os alunos foram indagados se conheciam o significado do termo "maquete". A maioria dos alunos, de ambas as turmas, respondeu afirmativamente. "Nós vamos fazer a sala de aula em miniatura", 
respondeu uma aluna do $3^{\circ} \mathrm{C}$. Para completar a fala dos alunos, foi comentado que a maquete é uma representação tridimensional, assim os elementos empregados na sua construção têm comprimento, largura e altura, formando um volume. Como os alunos pretendiam representar todos os objetos da sala, foi necessário esclarecer que não seria possível representar todos os objetos da sala. Assim, era necessário representar apenas aqueles apresentados na tabela. Para viabilizar o tempo, a pesquisadora encarregou-se de providenciar material reciclável suficiente para auxiliar na confecção da maquete.

Em seguida, foram formados quatro grupos de alunos e atribuiu-se a cada um deles uma função. Assim, um grupo ficou encarregado de confeccionar os armários; outro de posicionar e colar o material que representasse os alunos e suas mesas; outro deveria recortar as janelas, a porta, a lousa e o mapa-múndi; e um quarto grupo confeccionou a mesa da professora e escolheu como representar a professora e a lixeira. Entretanto, antes dos grupos iniciarem o seu trabalho, pediuse a eles que selecionassem, dentre o material disponível, aquele que apresentasse uma forma, proporção e estivesse numa quantidade adequada para a confecção da maquete, tendo por base a tabela de coleta de dados preenchida por eles. Todos os alunos buscaram dar a sua contribuição e pareciam felizes com essa atividade.

Com o passar do tempo, a maquete foi ganhando a forma esperada. Por fim, colou-se uma etiqueta em branco na "mesa" de cada aluno. Em seguida, pediu-se aos alunos que localizassem as suas mesas e colocassem os seus nomes nas etiquetas. Nessa atividade, os alunos tiveram a oportunidade de trabalhar as noções de descentralização, ou seja, os alunos puderam perceber a posição da porta, da janela, da mesa do professor, da lixeira, das mesas dos colegas direcionando, desta forma, o referencial para fora do próprio corpo. Tiveram também a oportunidade de perceber que a maquete podia ser observada em diferentes visões (visão frontal, lateral, oblíqua e vertical), dependendo da posição do observador.

Concluída esta etapa, os alunos ao perceberem o resultado do seu trabalho, expressaram seus sentimentos levantando-se e aplaudindo a maquete confeccionada. Abaixo, seguem as fotos da maquete realizada pelos alunos da $3^{\circ}$ Ano B. 


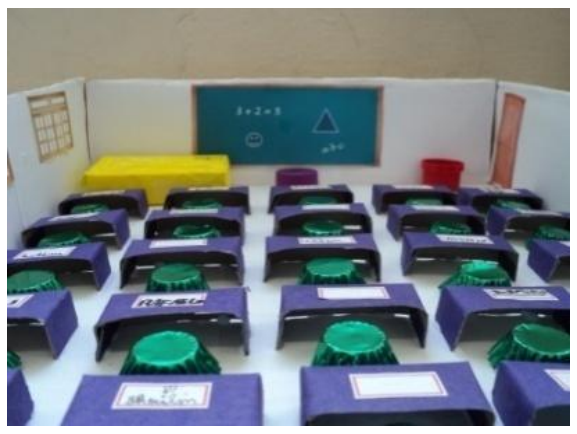

(a)

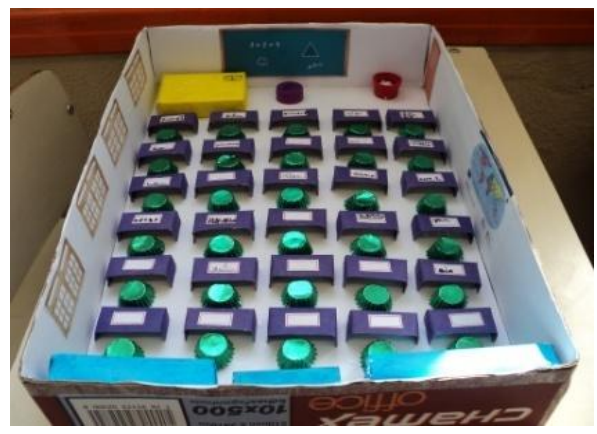

(b)

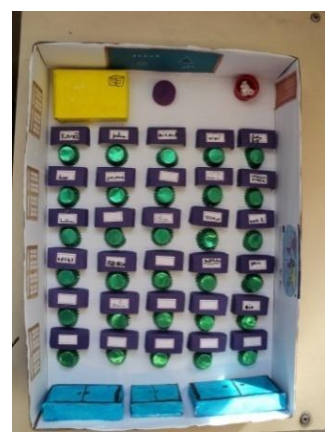

(c)

Figura 16 - Maquete da sala de aula feita por alunos do $3^{\circ}$ ano, turma "C". Visão frontal (a), Visão Oblíqua (b) e Visão Vertical (c). Fonte: a autora, 2012.

Etapa II. Traçado da planta baixa da maquete da sala de aula no celofane

Esta etapa consistiu na passagem da maquete (representação tridimensional) para a Planta Baixa da sala de aula (representação bidimensional). Os alunos da turma do $3^{\circ} \mathrm{B}$ confeccionaram quatro Plantas Baixas no pátio da Escola, por sugestão da professora. Apesar das distrações e discussões dos integrantes dos grupos, a atividade foi realizada com sucesso, pois todos os alunos participaram do processo.

Para a turma $3^{\circ}$ Ano C, decidiu-se que apenas uma Planta Baixa, da sala de aula no celofane, seria confeccionada na própria sala de aula. Entretanto, cada aluno teve a oportunidade de desenhar uma mesa e o assento correspondente. Para isso, a professora solicitou que todos os alunos escolhessem um Gibi e o lessem até que chegasse o momento para participar na realização do trabalho. Desta maneira, cada coluna de alunos era chamada para que desse a sua contribuição.

Assim, as crianças do $3^{\circ} \mathrm{B}$ e $3^{\circ} \mathrm{C}$ tiveram a oportunidade de treinar a Visão Vertical (de cima para baixo) que corresponde à própria visão do mapa, além de 
desenhar todos os objetos da maquete no celofane usando canetas coloridas permanentes.

Por fim, as plantas baixas feitas no celofane foram coladas em um papel sulfite A3, para que fosse possível acrescentar o título, legenda e o nome dos alunos que faziam parte do grupo. A atividade foi realizada com bastante entusiasmo. $\mathrm{Na}$ figura abaixo, é possível observar os alunos concluindo a planta baixa da sala de aula a partir de uma maquete.

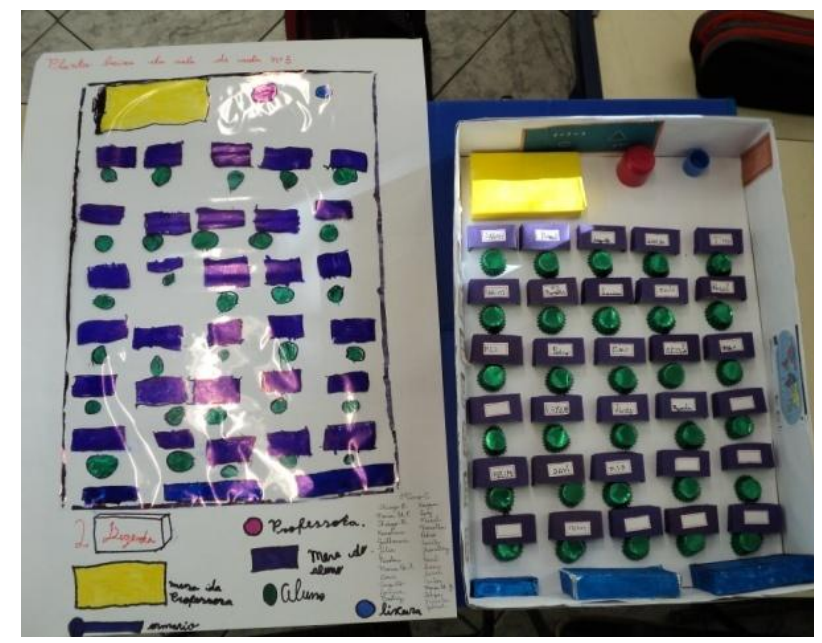

(a)

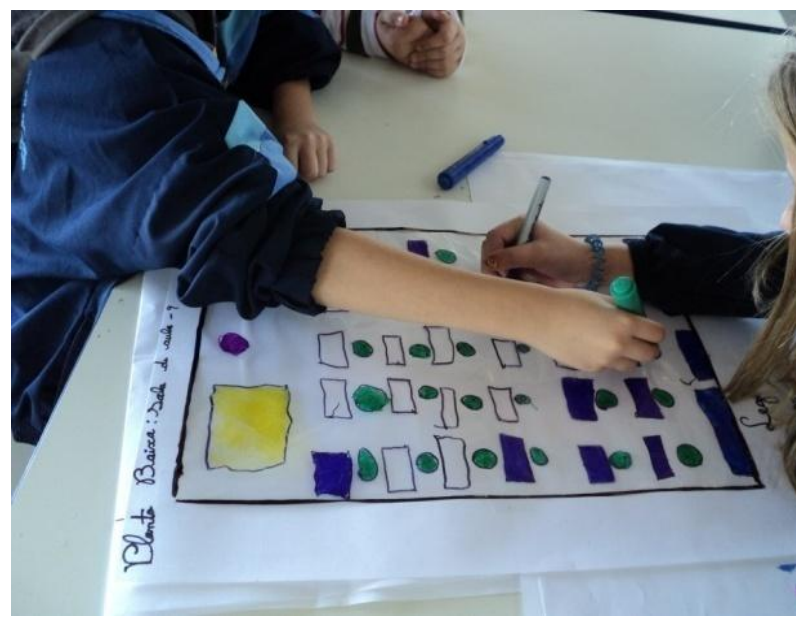

(b)

Figura 17 - Passagem da Maquete para a Planta da sala de aula. Atividade executada pelos alunos do $3^{\circ}$ ano, turma "C". (a) e (b). Fonte: a autora.

Etapa III. Avaliação da Prancha Temática: Localização na sala de aula

A avaliação da Prancha temática ocorreu de forma individual. Antes que os alunos iniciassem a resolução, procedeu-se à leitura da avaliação. $\mathrm{Na}$ oportunidade, retomou-se a localização de alguns objetos da sala de aula. Para o exercício que envolve a localização do aluno $A$, os alunos foram questionados se aquela representação correspondia à sala de aula deles. A resposta foi unânime: todos concordaram de que se tratava de outra sala de aula. Os alunos perceberam que a linhas azul e vermelha estavam traçadas no piso da sala de aula da representação. 
Após esta preparação, cada aluno teve a oportunidade de revisar os seus conhecimentos. A título de exemplo, segue abaixo um exemplo de uma avaliação.

Aplicação da Prancha Temática: Localização na sala de aula

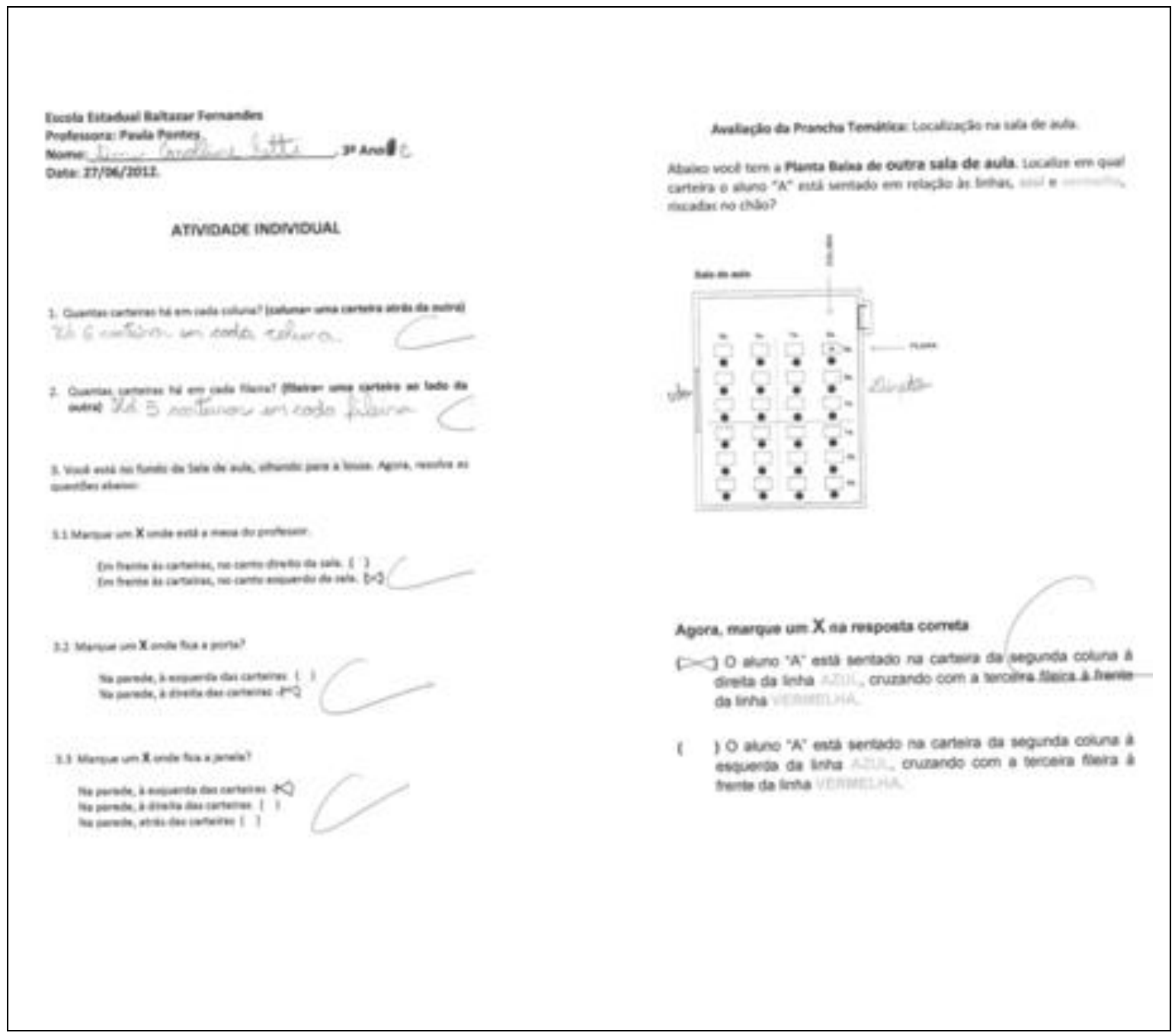

Quadro 14 - Exemplo da Avaliação realizada. Capítulo 1 - Ingressando no Atlas. Prancha Temática: Localização na sala de aula. $3^{\circ}$ ano, turma "C". Fonte: a autora. 


\section{Análise dos Resultados da Avaliação da Prancha Temática: LOCALIZAÇÃO NA} SALA DE AULA - 3ํ ano, turma B e C

Os gráficos 5 e 6 correspondem ao percentual de alunos das turmas dos 3os. anos B e C, respectivamente, segundo o número de questões corretamente respondidas por eles. Estas turmas B e C possuíam 27 e 24 alunos, respectivamente.

Gráfico 5

PERCENTUAL DOS ALUNOS DA TURMA DO $3 \circ$ ANO B, SEGUNDO $O$ NÚMERO DE QUESTÕES CERTAS. PRANCHA TEMÁTICA: LOCALIZAÇÃO NA SALA DE AULA - 2012

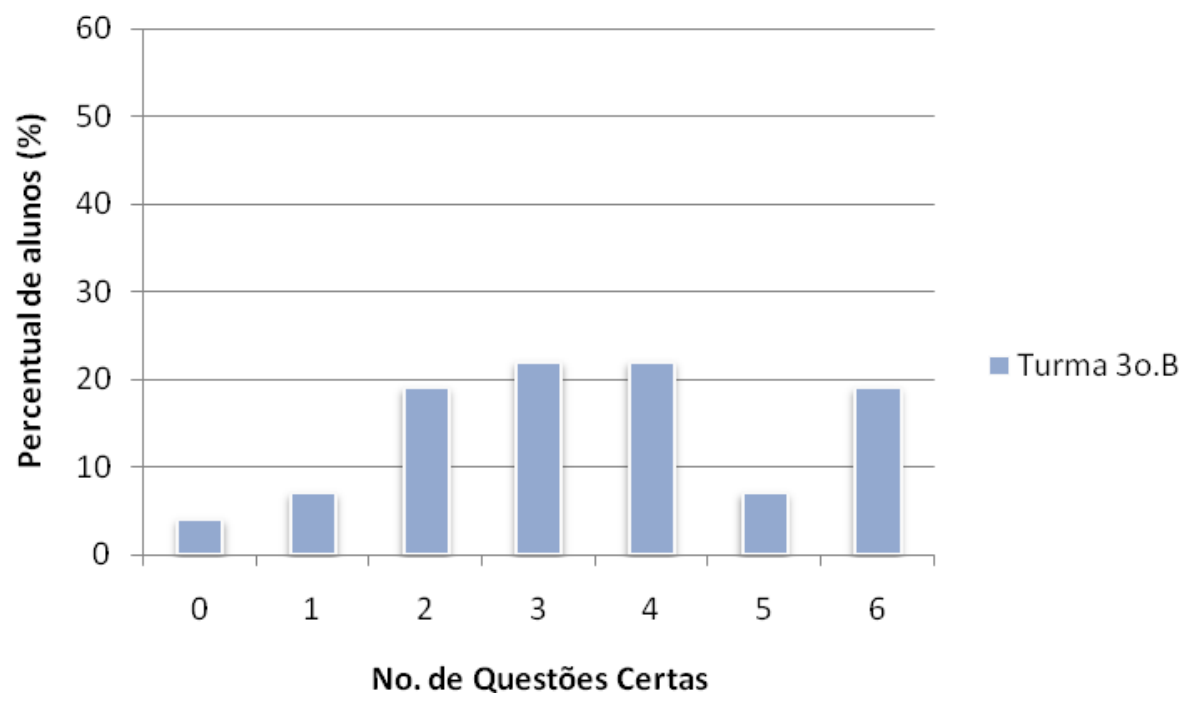

Fonte: a autora, 2012 
Gráfico 6

\section{PERCENTUAL DOS ALUNOS DA TURMA DO 3 ANO C, SEGUNDO O NÚMERO DE QUESTÕES CERTAS. PRANCHA TEMÁTICA: LOCALIZAÇÃO NA SALA DE AULA - 2012}

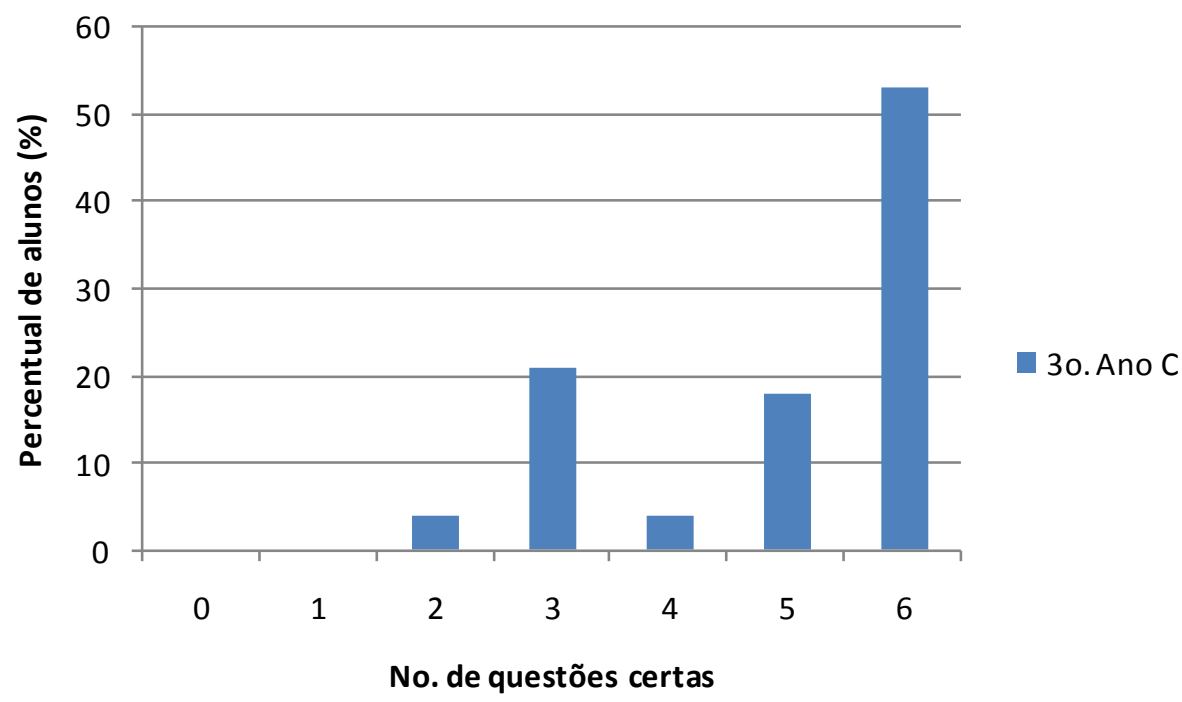

Fonte :a autora, 2012.

Da análise dos gráficos 5 e 6, nota-se que as turmas B e C alcançaram resultados distintos. Na turma do 3 o ano $\mathrm{B}$, a quantidade de questões corretamente respondidas pelos alunos se distribuiu de maneira relativamente uniforme. Por outro lado, na turma $3^{\circ}$ ano C, observou-se uma distribuição fortemente assimétrica, com grande concentração em 6 acertos (número máximo).

Vários fatores justificam a diferença representada pelos gráficos. O primeiro deles refere-se à estabilidade emocional. Os alunos da turma $3^{\circ}$ ano. $\mathrm{B}$, durante a execução das atividades, demonstraram dificuldade em aceitar a divisão das tarefas entre os membros do grupo, alguns deles choraram e com muita dificuldade chegaram a um acordo.

Além disso, os alunos desta turma se distraíam com facilidade. Por outro lado, os alunos da turma $3^{\circ}$ ano $\mathrm{C}$ eram mais tranquilos, possuíam mais disciplina, conversavam nos momentos oportunos e não tiveram problemas em aceitar a divisão das tarefas para a confecção da maquete. 
O segundo fator a ser destacado é que a turma $3^{\circ}$ ano $\mathrm{C}$, somente executou as suas atividades após a turma 3 ano B. Assim, a partir da experiência adquirida pela pesquisadora com a turma $\mathrm{C}$, esta procurou corrigir e aprimorar a explicação das atividades a serem executadas pelos alunos da outra turma.

Como terceiro fator, deve-se ressaltar que a turma $3^{\circ}$ ano $\mathrm{C}$, de maneira geral, encontrava-se bem alfabetizada e com um bom domínio da escrita, sendo que na turma $3^{\circ}$ ano $B$ havia alunos ainda em processo de alfabetização.

Apesar disto, notou-se que, em ambas as turmas, todos participaram ativamente das atividades. Segundo as próprias professoras, os resultados ocorreram dentro do esperado.

O gráfico n. 7 abaixo corresponde ao percentual de alunos de todas as turmas dos $3^{\circ}$ anos, segundo o número de questões corretamente respondidas por eles. A partir deste gráfico, é possível perceber que há uma distribuição assimétrica do percentual de alunos em função do número de questões certas, indicando que a maioria dos alunos acertou mais da metade das questões propostas.

Gráfico 7

PERCENTUAL DOS ALUNOS DE TODAS AS TURMAS DOS 3응 ANOS, SEGUNDO O NÚMERO DE QUESTÕES CERTAS. PRANCHA TEMÁTICA: LOCALIZAÇÃO NA SALA DE AULA - 2012

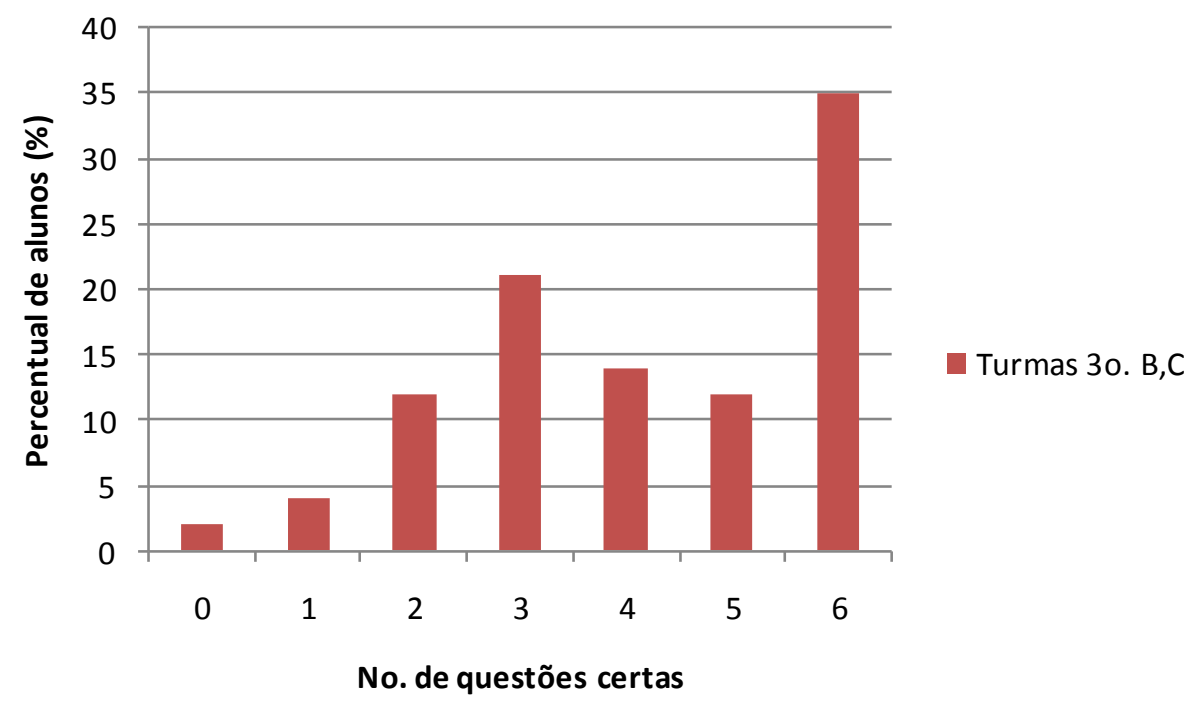

Fonte: a autora, 2012. 
As demais pranchas temáticas que compõem o Capítulo I - Ingressando no atlas foram trabalhadas com os alunos do $5^{\circ}$ ano. Assim, as atividades que envolveram a aplicação dessas pranchas serão comentadas oportunamente no Capítulo V - Sorocaba: Geografia.

\subsubsection{CAPÍTULO 5 - SOROCABA: GEOGRAFIA}

O capítulo V - Sorocaba: Geografia é composto pelas Pranchas Temáticas: Político, Relevo, Hidrografia, Geologia e recursos minerais, Vegetação, Clima, Área urbana e área rural, Uso da terra e cobertura do solo, População, Indústria, Rede Viária, Saúde, Educação e Turismo.

Este capítulo foi avaliado, parcialmente. Contou com a colaboração das professoras e alunos das turmas do 5 o ano C, D e E.

No $5^{\circ}$ ano "C" foi avaliado somente a Prancha Temática do relevo. Para o $5^{\circ}$ ano "D" a professora participou das reuniões e teve acesso a todo o material a ser analisado, porém, não foi avaliada nenhuma prancha nesta turma.

Ficou para o $5^{\circ}$ ano "E" a avaliação de cinco pranchas: Sorocaba: relevo, clima, área urbana e rural, população e Uso da terra e cobertura do solo.

Algumas decisões foram tomadas durante a reunião do dia 07 de agosto de 2012, da qual participaram três professoras dos $5^{\circ}$ anos. Assim, embora a 
professora Naira Maria (5ำ ano D) tenha demonstrado interesse em trabalhar as pranchas com seus alunos isso não foi possível, dado ao pouco tempo que restava para finalizar essa parte da pesquisa. Entretanto, foi sugerido pelas demais professoras e pela própria Naira que ela acompanhasse as intervenções na sala de aula do $5^{\circ}$ ano "E" como ouvinte. Também, ficou acertado que o $5^{\circ}$ ano $\mathrm{C}$ da professora Maria Cristina participaria apenas da aplicação da prancha temática do relevo. Para a professora Eliane do $5^{\circ}$ ano "E" ficou estabelecido que ela repassasse às suas colegas (5 ano $\mathrm{C}$ e D) o material trabalhado em sala de aula, cumprindo a função de "professor replicador", tendo em vista que nesta turma seriam avaliadas cinco pranchas temáticas.

A avaliação das pranchas temáticas selecionadas para o $5^{\circ}$ ano "C" e "E" envolveu de forma decisiva um trabalho de Iniciação cartográfica. Assim, foi levantado primeiramente aos alunos o que vem a ser um mapa e para o que ele serve. E em seguida, foi trabalhado: a Localização pela Orientação, visão frontal, oblíqua e vertical, construção do símbolo, organização legenda, projeção, a linguagem da representação gráfica e os elementos do mapa.

Estas intervenções foram realizadas de forma oportuna e contínua durante as aplicações das cinco pranchas temáticas. Desta maneira, entre a aplicação de uma prancha temática e a seguinte, buscava-se organizar, reorganizar, integrar e reintegrar informações aos novos conhecimentos e aos já existentes, mediante aulas expositivas, uso de maquetes e aplicação de atividades realizadas em grupo e individual, etc.

Nestes momentos, a pesquisadora se colocou na situação de professor mediador do conhecimento. Após essa preparação foi aplicado um exercício específico para avaliar a prancha temática em questão. O objetivo desse momento foi verificar a eficácia do protótipo do atlas frente aos seus usuários - os alunos.

A seguir será apresentado o modelo de proposta metodológica para avaliação parcial do capítulo, propostas de atividades, alguns exemplos de atividades realizadas pelos alunos e, por fim, uma breve análise dos resultados mediante gráficos estatísticos. 


\subsection{Relevo}

\section{Modelo da Proposta metodológica para avaliação parcial do CAPÍTULO 5 - SOROCABA: GEOGRAFIA. PRANCHA TEMÁTICA - SOROCABA: RELEVO - 5 ano.}

Foram apresentados às professoras na reunião, do dia 07 de agosto de 2012, os modelos de propostas de atividades para a avaliação do Capítulo V Sorocaba: Geografia. Um modelo para cada uma das cinco pranchas temáticas selecionadas: Relevo, Clima, Área urbana e rural, População total, urbana e rural; Uso da terra e cobertura do solo.

Todos os modelos de propostas foram aprovados sem nenhuma ressalva para os elementos que compõem as pranchas temáticas: textos, figuras, gráficos e mapas temáticos. 
Proposta metodológica para avaliação parcial do CAPÍTULO 5 - Sorocaba: GEOGRAFIA. Prancha Temática: RELEVO - 5 Ano, turmas C e E. Escola Estadual Baltazar Fernandes.

Professoras: Maria Cristina $-5^{\circ}$ ano $C$ (manhã)

Eliane Rodrigues - 50 E (tarde)

\begin{tabular}{|c|c|c|}
\hline ATIVIDADES & CONTEÚDOS & O QUE SE ESPERA DO ALUNO \\
\hline $\begin{array}{c}\text { ETAPA I } \\
\text {.Construção de uma } \\
\text { Rosa dos Ventos } \\
\text { (direções cardeais e } \\
\text { colaterais). Atividades }\end{array}$ & $\begin{array}{l}\text { Iniciação } \\
\text { Cartográfica: } \\
\text { Localização pela } \\
\text { Orientação }\end{array}$ & $\begin{array}{l}\text { Que o aluno consiga dar a } \\
\text { localização de um lugar com } \\
\text { apoio das direções cardeais. }\end{array}$ \\
\hline $\begin{array}{c}\text { ETAPA II } \\
\text { Definição e noções } \\
\text { básicas de } \\
\text { classificação do } \\
\text { Relevo. Noções } \\
\text { Básicas. } \\
\text {.Diferença entre } \\
\text { altitude e altura } \\
\text {.Atividades envolvendo } \\
\text { a maquete simplificada } \\
\text { do relevo. } \\
\text {. Atividades envolvendo } \\
\text { a maquete do relevo de } \\
\text { Sorocaba. }\end{array}$ & $\begin{array}{c}\text { Iniciação } \\
\text { cartográfica: visão } \\
\text { frontal, oblíqua e } \\
\text { vertical, fotografias } \\
\text { aéreas, carta } \\
\text { topográfica, curvas } \\
\text { de nível }\end{array}$ & $\begin{array}{l}\text { Espera-se que o aluno perceba } \\
\text { que o relevo se apresenta como } \\
\text { um fenômeno contínuo que se } \\
\text { organiza de baixo para cima, } \\
\text { tomada a referência do nível } \\
\text { médio das águas do mar, numa } \\
\text { sequência ordenada crescente de } \\
\text { faixas de altitudes intercaladas } \\
\text { correspondentes aos intervalos } \\
\text { entre as curvas de nível. }\end{array}$ \\
\hline \begin{tabular}{cc}
\multicolumn{2}{c}{ ETAPA III } \\
Avaliação da Prancha \\
temática do & Relevo \\
(texto e mapa) &
\end{tabular} & $\begin{array}{l}\text { Título } \\
\text { Legenda (cores } \\
\text { hipsométricas) } \\
\text { Orientação } \\
\text { Fonte }\end{array}$ & $\begin{array}{l}\text { Que o aluno perceba no mapa do } \\
\text { relevo onde estão as partes mais } \\
\text { altas e mais baixas no município } \\
\text { de Sorocaba. }\end{array}$ \\
\hline
\end{tabular}

Quadro 15 - Proposta metodológica para avaliação parcial do Capítulo 5 - Sorocaba: Geografia. Prancha Temática: Relevo - 5ํAno. Fonte: a autora, 2012. 


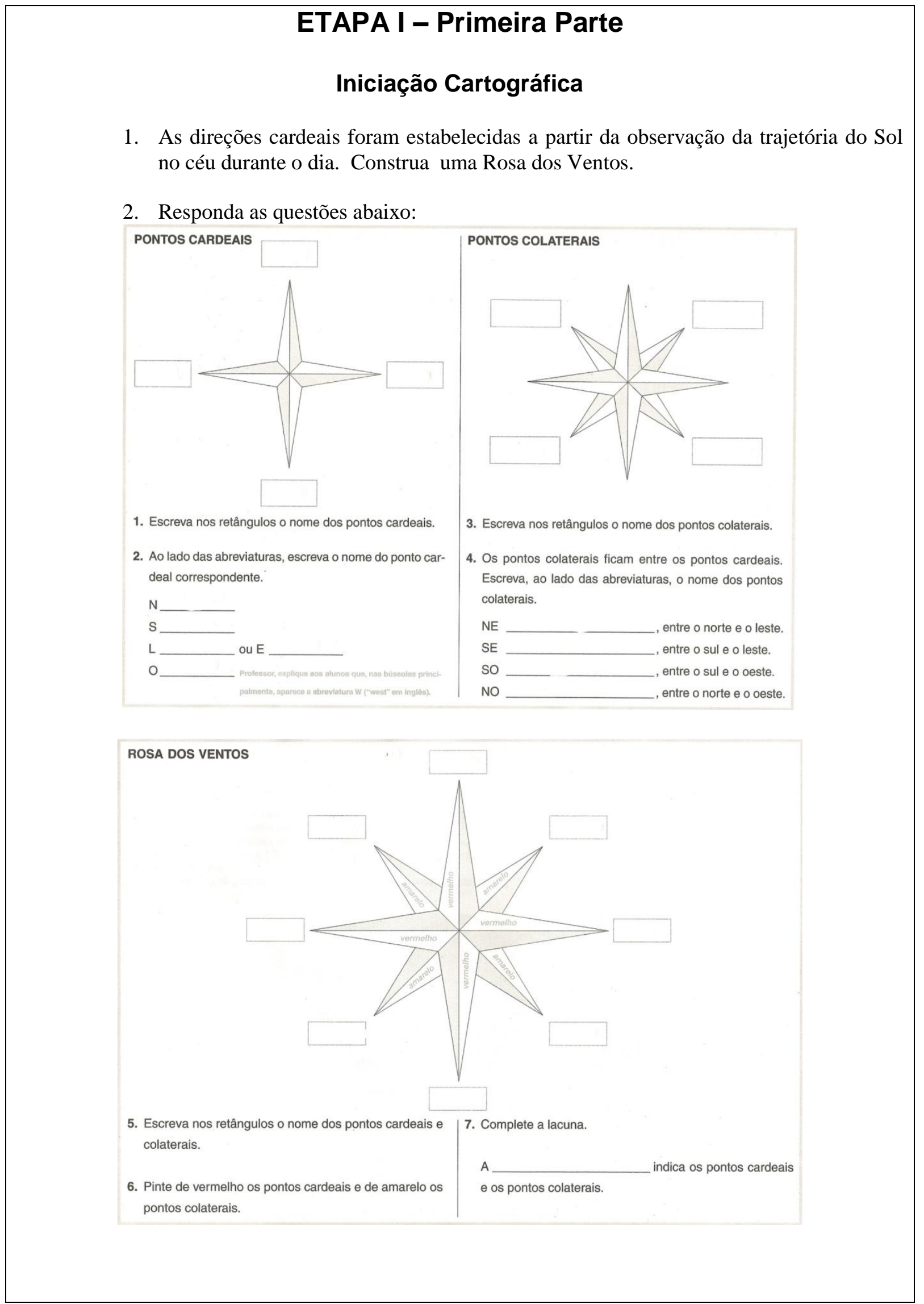

Quadro 16 - Proposta das atividades para avaliação parcial do Capítulo 5 - Sorocaba: Geografia. Prancha Temática: Relevo - 5ํㅡㅅㅡ. I Etapa - Primeira Parte. Fonte: Ferreira, 1995. 


\section{ETAPA I - Segunda Parte}

3. Observe o mapa do Brasil: Político abaixo e responda às questões.

Use a Rosa dos Ventos em papel filme de poliéster.

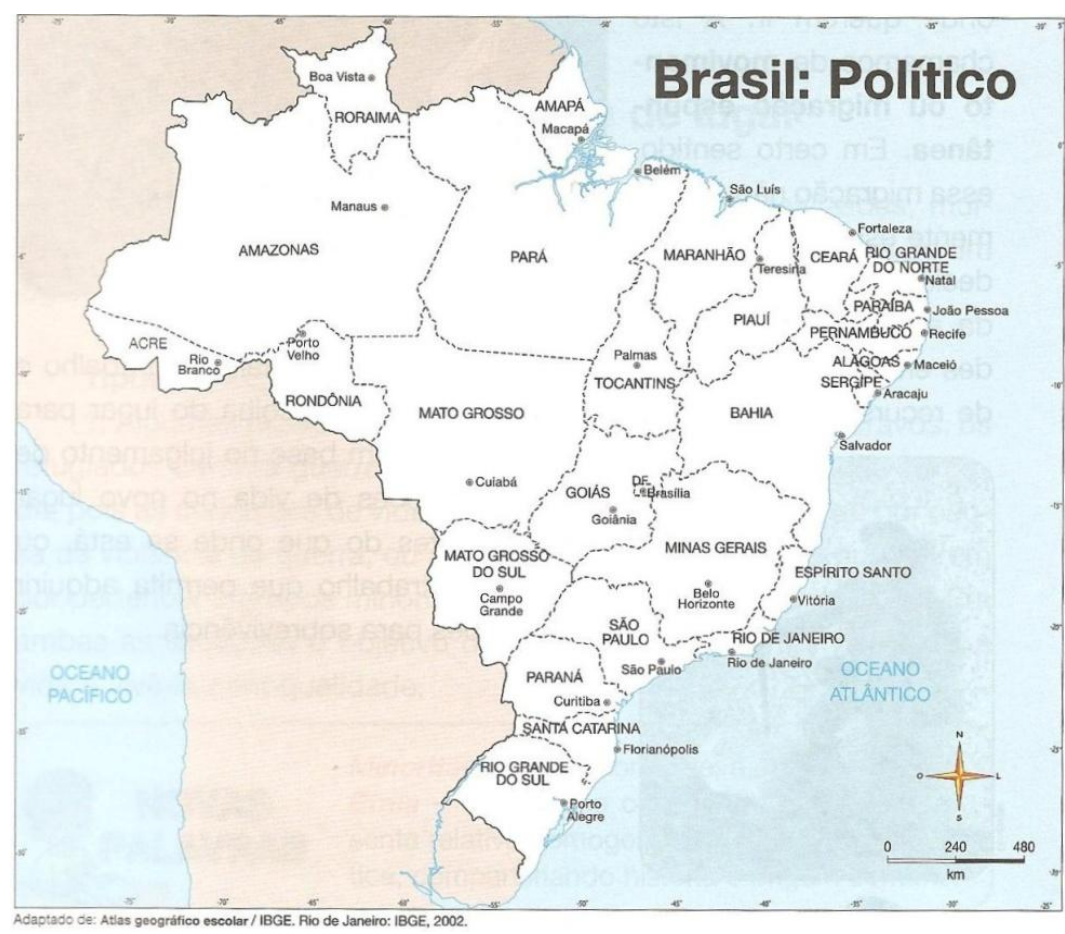

Imagine que você esteja se preparando para uma viagem passando por algumas capitais do país. Que direção você deverá tomar para:

a. Saindo de Goiânia ir para São Paulo?

b. De São Paulo para Cuiabá?

c. De Cuiabá para Belém?

d. De Belém para Aracajú?

Obs.: Foi distribuído para cada aluno uma Rosa dos Ventos confeccionada em papel filme poliéster.
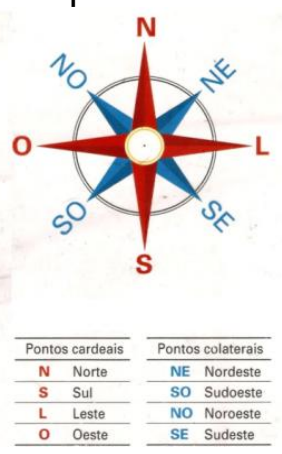

Quadro 17 - Proposta das atividades para avaliação parcial do Capítulo 5 - Sorocaba: Geografia Prancha Temática: Relevo. 5 Ano. Etapa I - Segunda Parte. Fonte: a autora, 2012. 


\section{ETAPA II - Primeira Parte}

\section{RELEVO}

Relevo é o conjunto de formas que modelam a superfície terrestre. Ele Pode ser modificado por terremotos, movimentos tectônicos, erupções vulcânicas, erosão e deposição (chuva, ventos, etc.) e, ainda, pela interferência humana.

$\mathrm{Na}$ paisagem da figura abaixo você tem as principais formas do relevo:

Montanha ou monte - Formas de relevo muito elevadas.

Cordilheira - Conjunto de montanhas. Ex. Cordilheira do Himalaia (Ásia), Andes (América do Sul), Rochosas (América do Norte) e Alpes (Europa).

Serra - Relevos acidentados formados por partes altas seguidas por saliências e topos aguçados. Ex. Serra de São Francisco (Sorocaba - SP).

Colina ou morro - pequena elevação do terreno.

Vale - Zona baixa alongada entre montanhas.

Planalto - São terrenos relativamente planos e situados em áreas de altitude mediamente elevadas. São limitados, pelo menos de um lado, por superfícies mais baixas.
Planície - São áreas planas ou suavemente onduladas formadas pela deposição de sedimentos transportados pela ação da água ou do vento.

Depressão - Conjunto de relevos planos ou ondulados que ficam abaixo do nível de altitude das regiões que estão próximas.

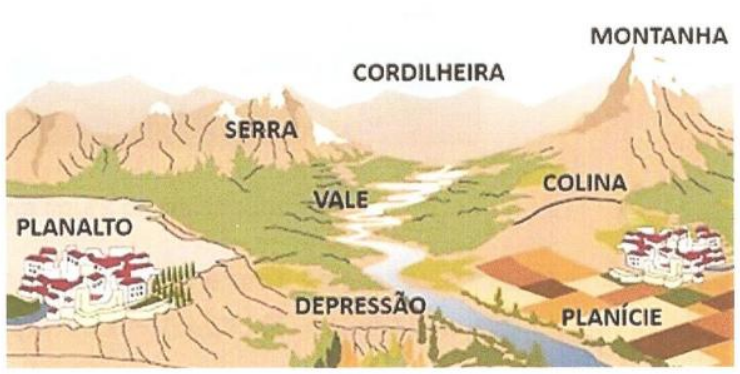

\section{Leia o texto e observe a figura. Agora responda as questões:}

Relevo é o conjunto de diversas formas da crosta terrestre que dão uma sensação de uma sucessão contínua de altos e baixos.

Principais formas do relevo: montanha, cordilheira, serra, colina, vale, planalto, planície e depressão. Nas figuras 1 e 2 você tem a representação de algumas formas do relevo. Figura 1.

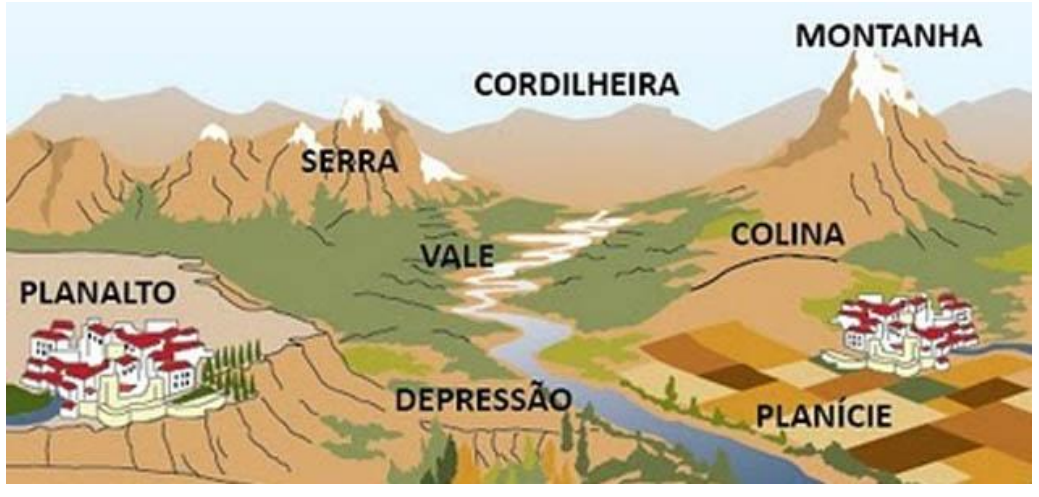

a. Quais as formas de relevo você observa na paisagem da figura 1?

b. Na figura 1 você tem uma paisagem reunindo áreas urbanas e uma área rural. As áreas urbanas estão assentadas em que tipos de relevo? E a área rural?

Quadro 18 - Proposta das atividades para avaliação parcial do Capítulo 5 - Sorocaba: Geografia Prancha Temática: Relevo. 5ํㅡㄹ. Etapa II - Primeira parte. Fonte: a autora, 2012. 


\section{ETAPA II - Segunda Parte}

Atividade: Maquete do Relevo

\begin{tabular}{|l|l|}
\hline $\begin{array}{l}\text { 1. Desenhe uma montanha } \\
\text { (desenho livre observando a } \\
\text { maquete de frente). }\end{array}$ & $\begin{array}{l}\text { 2. Agora tente representar a mesma } \\
\text { montanha, observando-a de } \\
\text { cima para baixo, na vertical } \\
\text { (desenho livre). }\end{array}$ \\
\hline
\end{tabular}

3. Vamos representar a montanha, com suas variações de altitude usando curvas de nível. Para isso, use a maquete do relevo (anexo).

Faça a correspondência entre os morros e as representações corretas:
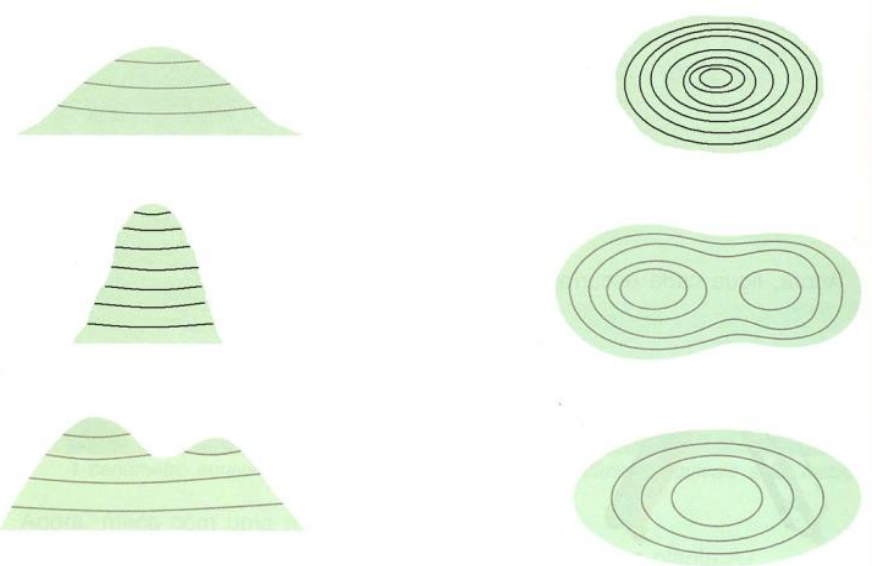

Observe as figuras e marque um $\mathrm{X}$ na representação correspondente:
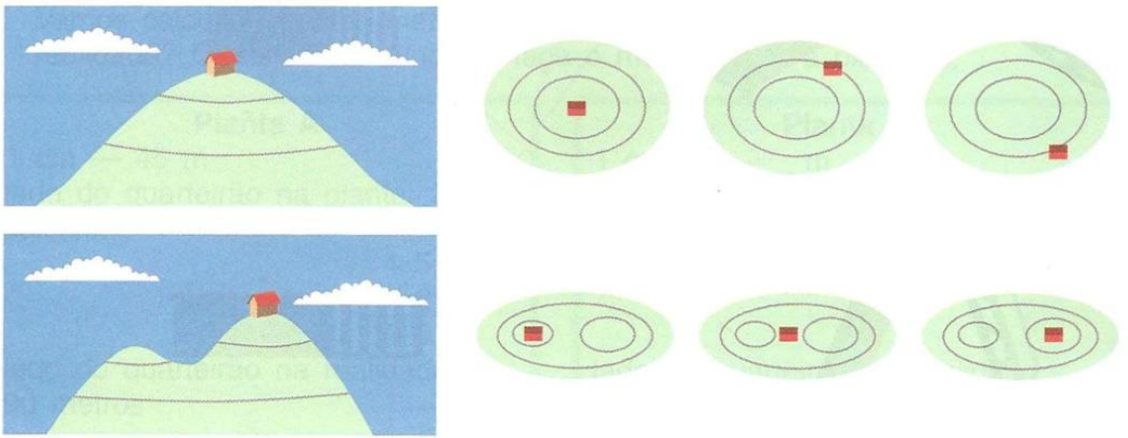

Quadro 19 - Proposta das atividades para avaliação parcial do Capítulo 5 - Sorocaba: Geografia Prancha Temática: Relevo. 5ำ Ano. Etapa II - Segunda parte. Fonte: ALMEIDA, et al. 1995; SIMIELLI, 1996. 


\title{
ETAPA III - Primeira Parte
}

\author{
Avaliação da Prancha Temática - Sorocaba: Relevo
}

\section{Relevo}

Relevo é o conjunto de diversas formas da crosta terrestre. Assim, se tem: planaltos, planícies, depressões, montanhas, morros, vales etc. O Rio Sorocaba junto com todos os seus afluentes que compõem a respectiva bacia hidrográfica dentro do território de Sorocaba são responsáveis pela modelagem do relevo.

Sorocaba tem um relevo ondulado. Na sua porção sudeste há altos de serra. A altitude média do município é de 632 metros em relação ao nível do mar. A maior altitude é de 1028 metros nas cabeceiras do rio Pirajibu, na Serra de São Francisco, próximo à divisa com Alumínio.

$\mathrm{Na}$ foto abaixo é possível observar no primeiro plano uma região mais alta, no centro a área urbana está assentada em uma porção menos elevada e ao fundo, percebe-se a Serra de São Francisco com as altitudes mais elevadas da região.

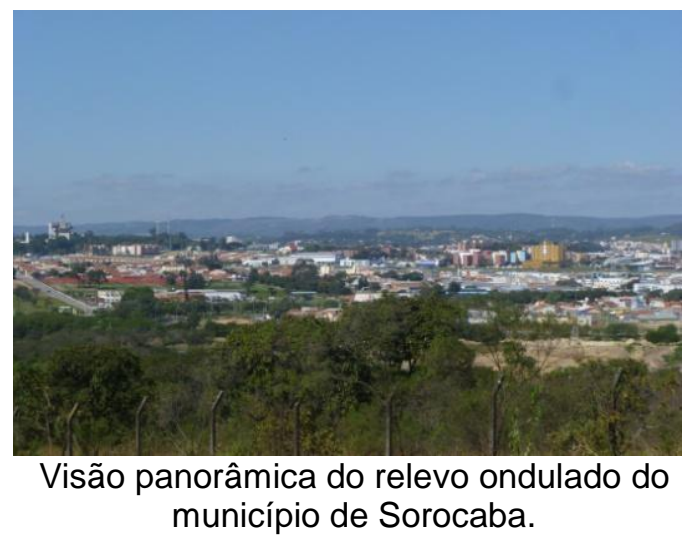

$\mathrm{Na}$ região leste, o bairro de Brigadeiro Tobias está assentado na região com as maiores altitudes, justamente por ser o mais próximo da Serra de São Francisco. A menor altitude é de $539 \mathrm{~m}$ e está no vale do rio Sorocaba, no ponto que atravessa a divisa para entrar nos municípios vizinhos de Porto Feliz e Iperó, servindo-lhes de divisa.

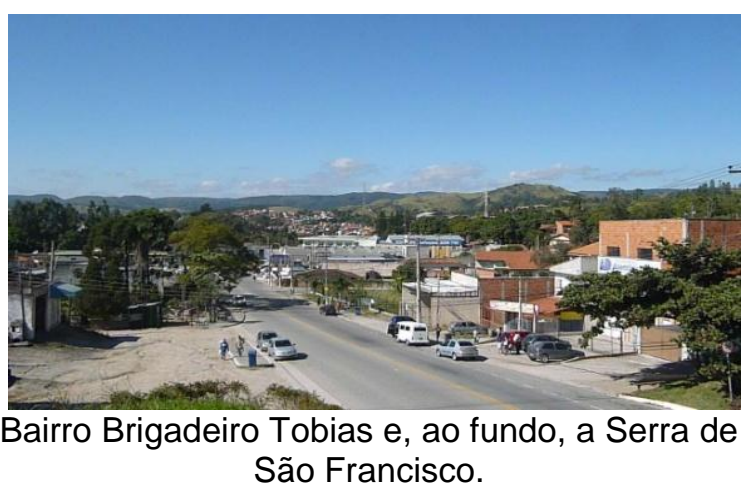

O termo "Sorocaba" que em tupi-guarani significa "terra rasgada" dado ao município em questão, reflete bem a modelagem do seu relevo.

Segundo AB'SABER (1954), Sorocaba está situada na borda da Depressão Periférica Paulista, na Linha de Quedas Apalachianas, dando a sensação de uma contínua sucessão de altos e baixos.

Quadro 20 - Proposta das atividades para avaliação parcial do Capítulo 5 - Sorocaba: Geografia Prancha Temática: Relevo. 5N Ano. Etapa III - Primeira parte. Fonte: a autora, 2012. 


\section{ETAPA III - Segunda Parte}

Observe o mapa abaixo e responda às questões:

1) Onde estão as altitudes mais elevadas do município de Sorocaba?

2) Onde estão as altitudes menos elevadas?

3) Em qual porção do município se encontra a cabeceira do rio Pirajibu-Mirim?

SOROCABA:

RELEVO

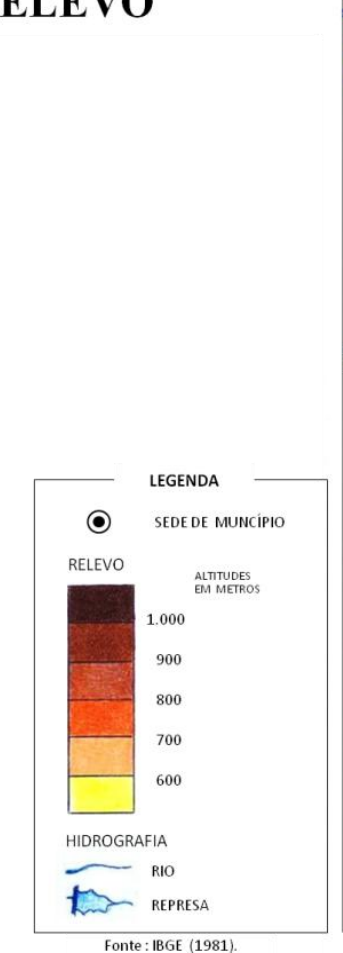

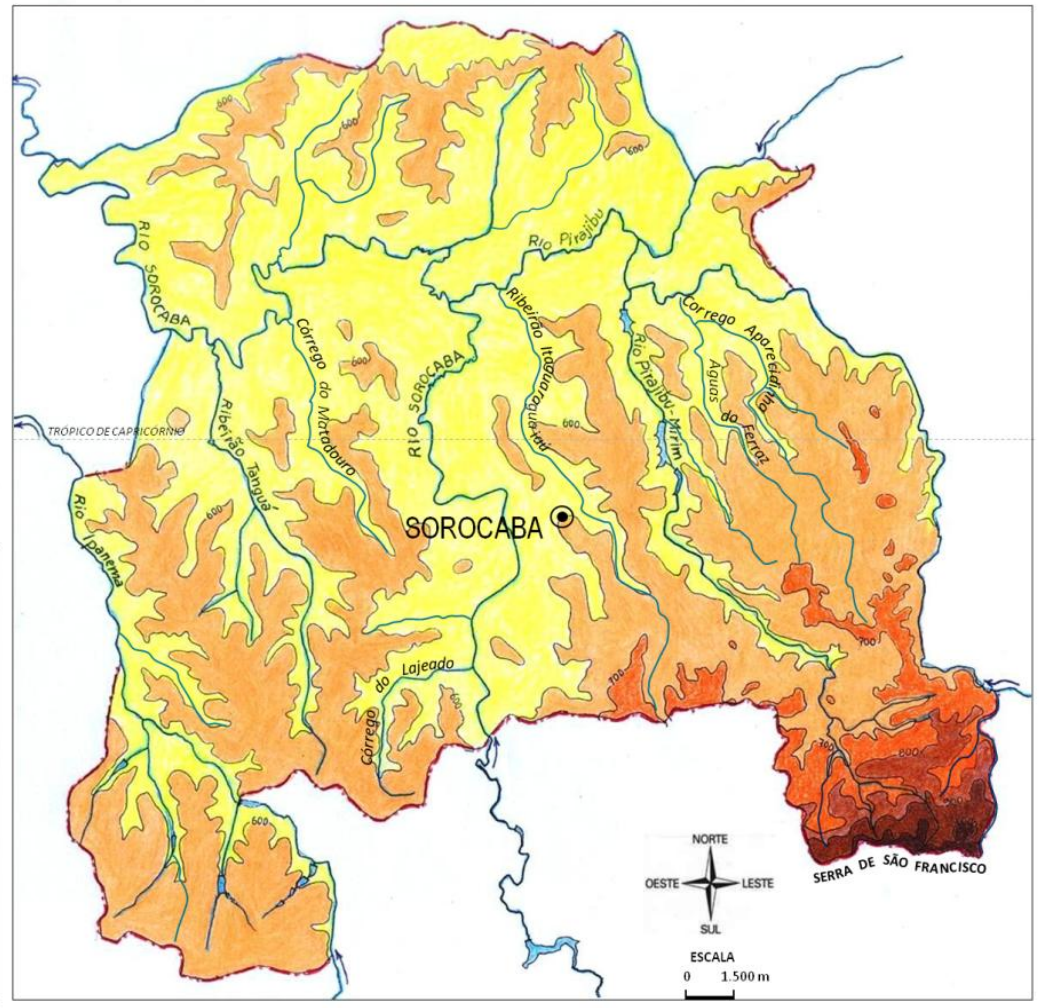

Quadro 21 - Proposta das atividades para avaliação parcial do Capítulo 5 - Sorocaba: Geografia Prancha Temática: Relevo. 5ํ Ano. Etapa III - Segunda parte. Fonte: a autora, 2012. 


\section{Apresentação das atividades executadas pelos alunos}

\section{PRANCHA TEMÁTICA - RELEVO}

Antes de dar início à avaliação da Prancha Temática Relevo nas turmas dos $5^{\circ}$ anos "C" e "E", foi necessário trabalhar a Iniciação Cartográfica. Assim, esse trabalho começou pela Localização pela Orientação, escala, projeção, título, legenda e fonte do mapa. Essa atividade foi desenvolvida com aulas expositivas apoiadas em apresentações de vídeos, mapas, texto, sempre acompanhadas de atividades individuais ou em grupos.

A cada avaliação das pranchas temáticas, esse trabalho de Iniciação Cartográfica era retomado de uma forma mais concisa.

Esta etapa contou com a colaboração das professoras que procuravam trabalhar outras atividades relacionadas ao que estava sendo tratado em sala de aula nos dias em que a pesquisadora não estava presente.

Seguem abaixo - ETAPA I - alguns exemplos de atividades voltadas para a Iniciação Cartográfica executadas pelos alunos. 


\section{ETAPA I - Primeira Parte}

\section{ESCOLA ESTADUAL BALTAZAR FERNANDES}

Aluno: Gowherme Turma: $:^{\circ} E$. Data: $0810 \% / 2$. Professora Elians

1. Desenhe uma cruz ( $11 \mathrm{~cm}$ para a linha horizontal e $11 \mathrm{~cm}$ para a linha vertical).

2. Agora desenhe sobre o centro um $X$ menor que o tamanho da cruz ( $1 \mathrm{~cm}$ para cada lado do $X)$

3. Agora ligue as pontas de suas retas. Coloque os pontos cardeais (norte, sul, leste e oeste)

4. Prolongue o $X$ sobre a cruz ( $3,5 \mathrm{~cm}$ para cada lado). Ligue as pontas de suas retas. Coloque os pontos colaterais ( nordeste, sudeste, sudoeste e noroeste)

5. Pinte de vermelho os pontos cardeais e de amarelo os pontos colaterais
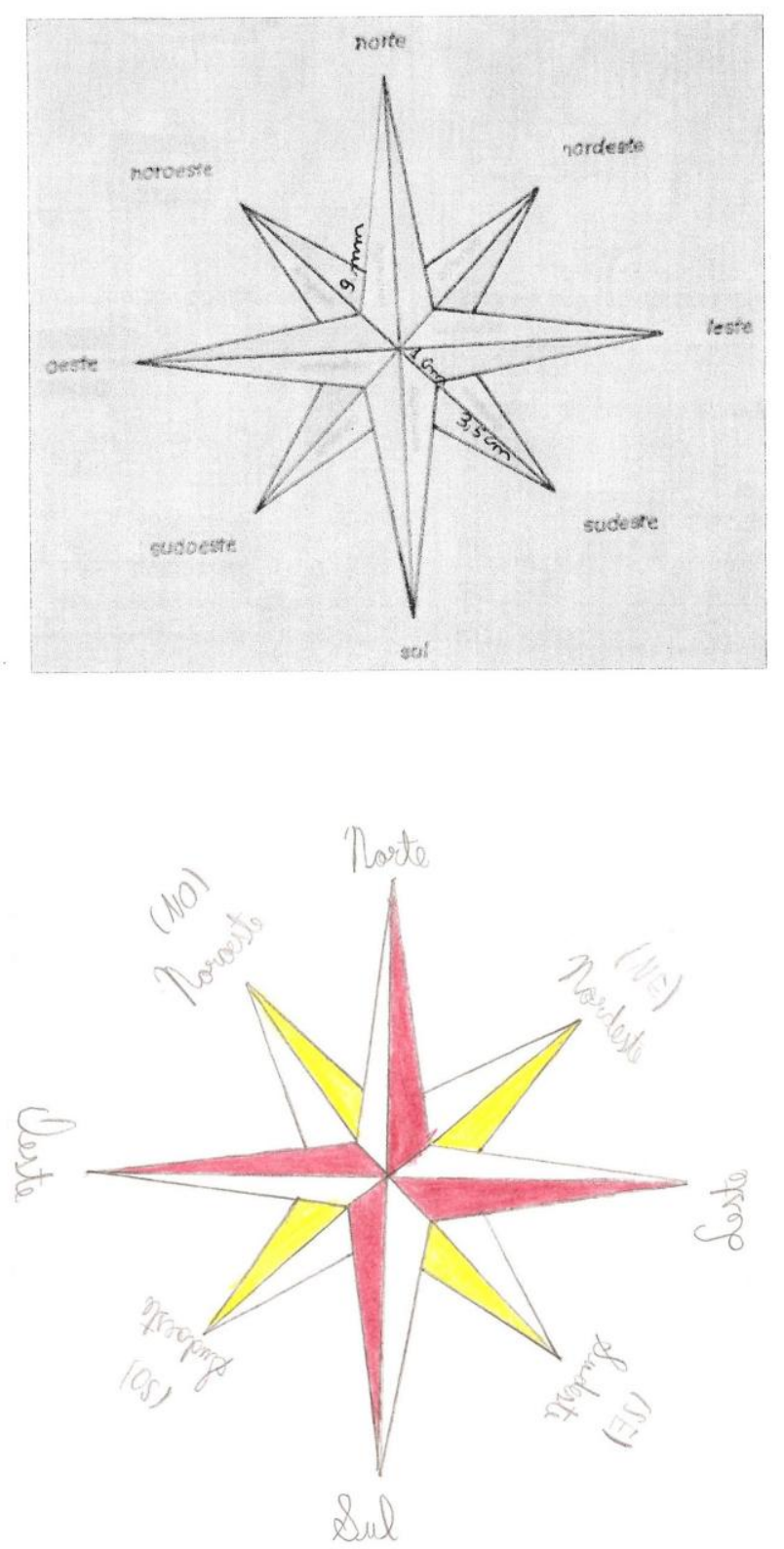

Quadro 22 - Exemplo das atividades de iniciação cartográfica: Orientação, como subsídio para a avaliação parcial do Capítulo 5. Prancha Temática: Relevo. 5aa, turma "E". Etapa I - Primeira Parte. Fonte: a autora, 2012. 


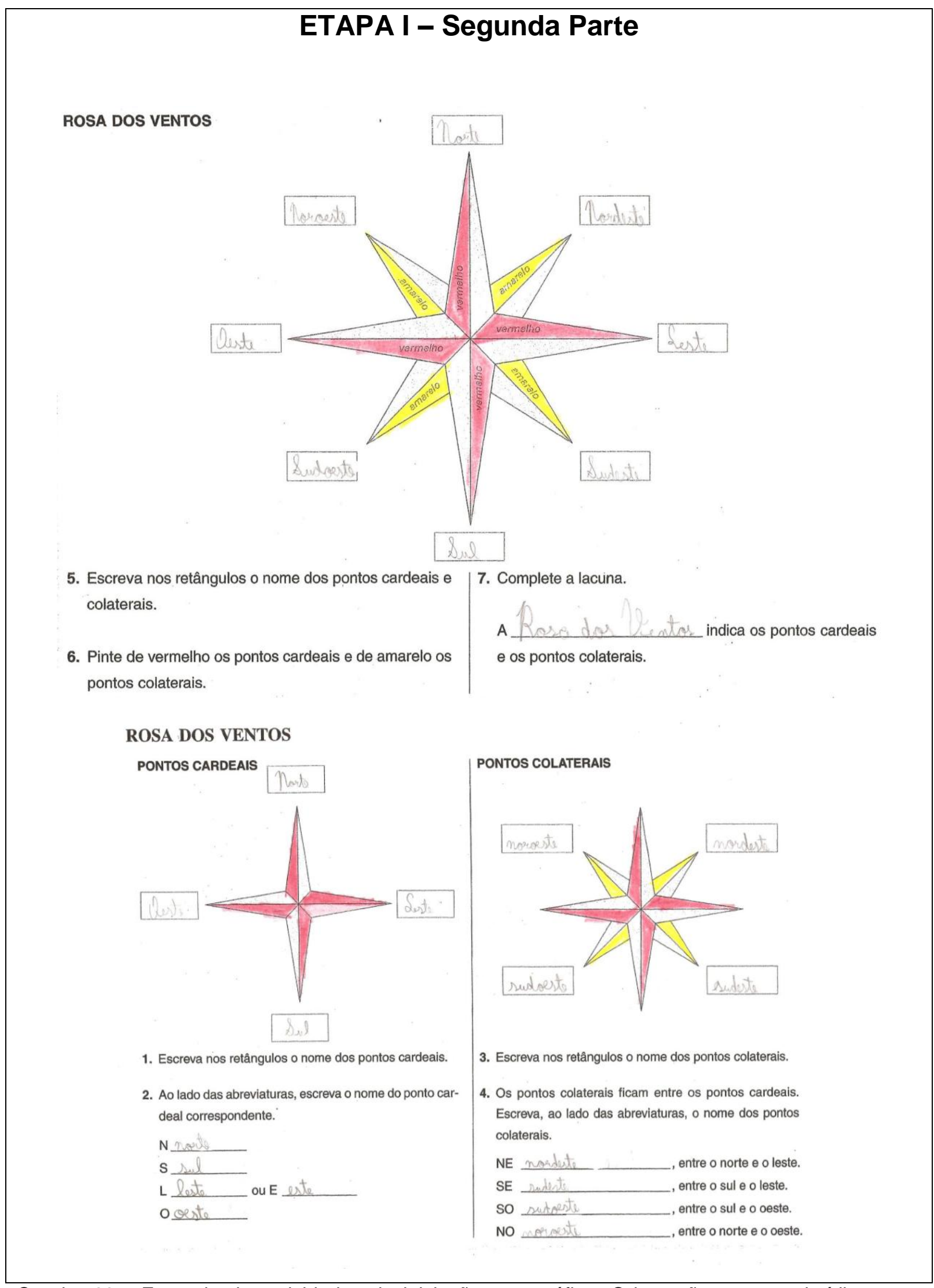

Quadro 23 - Exemplo das atividades de iniciação cartográfica: Orientação, como subsídio para a avaliação parcial do Capítulo 5. Prancha Temática: Relevo. 5 ano, turma "E". Etapa I - Segunda parte. 


\section{ETAPA I - Terceira Parte}

$$
\text { Guilherme } \quad 5^{\circ} \text { ano E } 14 / 08 / 2
$$

Observe o mapa do Brasil: Político abaixo e responda as questões. Use a Rosa dos Ventos em papel filme de poliéster.

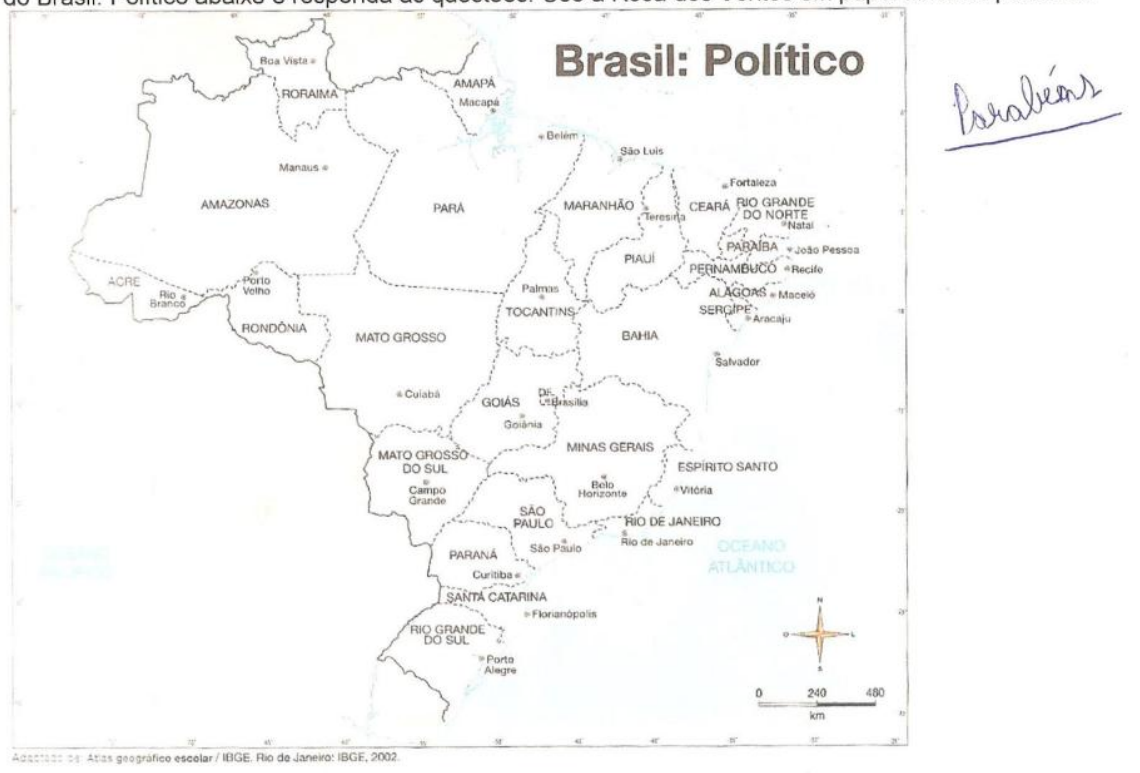

Imagine que você esteja se preparando para uma viagem passando por algumas capitais do país. Que direção você deverá tomar para:

a. Saindo de Goiânia para São Paulo?

b. De São Paulo para Cuiabá?

c. De Cuiabá para Belém?

d. De Belém para Aracajú?

Quadro 24 - Exemplo das atividades de iniciação cartográfica: Orientação, como subsídio para a avaliação parcial do Capítulo 5. Prancha Temática: Relevo. 5ำ ano, turma "E". Etapa I - Terceira parte. Fonte: a autora, 2012. 


\section{ETAPA II}

Nesta etapa foi trabalhado com os alunos, o conceito de relevo e sua classificação. Essa discussão foi importante para prepará-los para o entendimento do relevo do município de Sorocaba.

Segue abaixo, um exemplo de atividade aplicada aos alunos, cuja intenção era para que eles além de identificarem os tipos de relevo na paisagem, também fossem capazes de perceber na paisagem os diferentes assentamentos para as áreas urbanas e rurais.

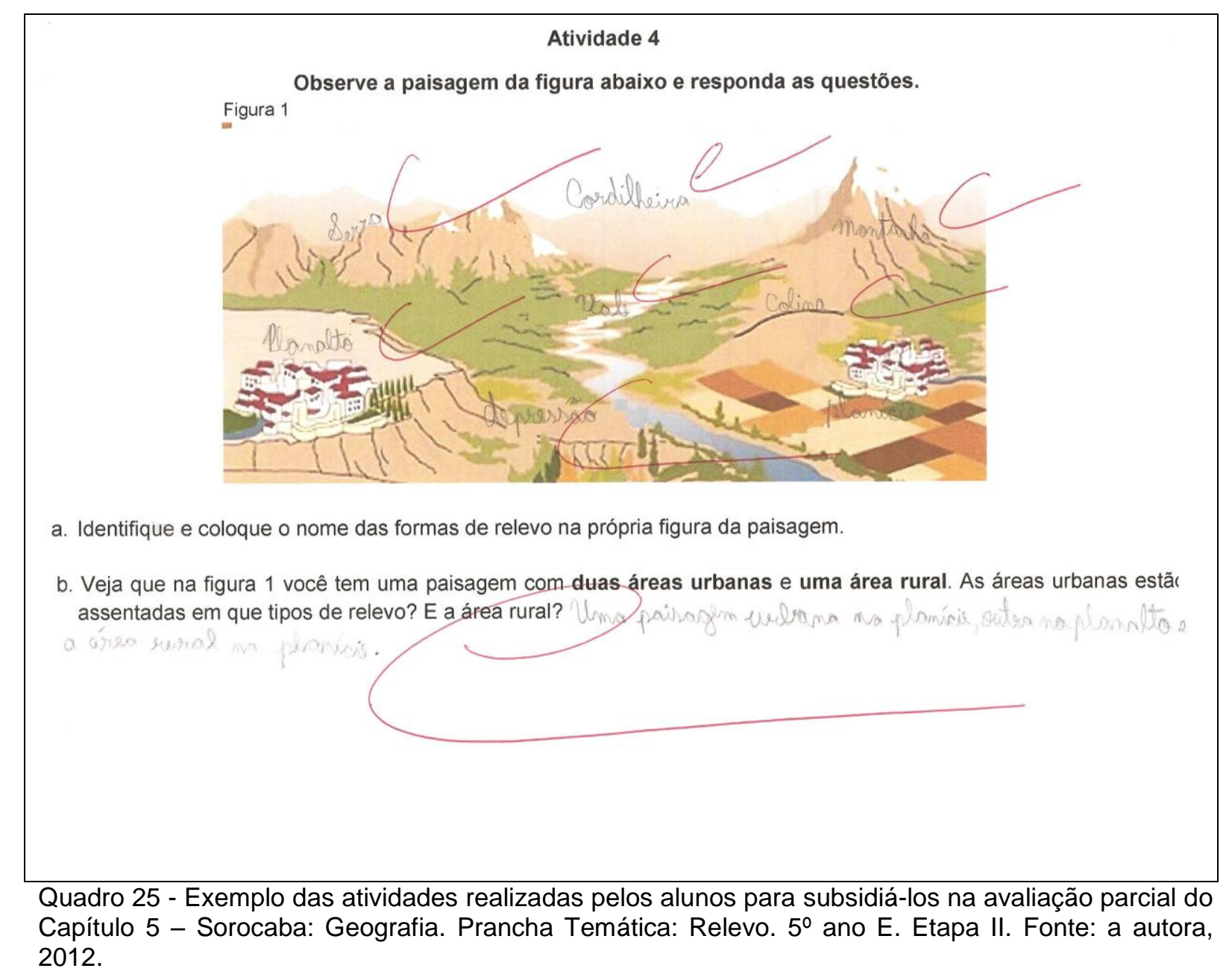


Após esse trabalho foi dado início à preparação do aluno para 0 entendimento da representação do relevo através das curvas de nível. Esse momento consistiu na formação de quatro grupos para o trabalho com uma maquete de uma montanha vulcânica, fatiada em três partes.

Para cada grupo foi entregue a maquete da ilha vulcânica sobre uma folha A4 azul (para representar o oceano). Em seguida, foi lançado o desafio aos alunos para representarem a maquete da montanha em um plano (folha de papel), através de dois desenhos livres. O primeiro desenho da montanha seria feito olhando-a de "frente", e o segundo desenho, olhando-a de "cima para baixo".

Todos os grupos conseguiram, de forma fácil, desenhar a montanha olhando-a de "frente". Mas, quando chegou o momento de desenhar a mesma montanha, olhando-a de "cima para baixo", boa parte dos alunos ficou agitada e formulou inúmeras perguntas no sentido de, com as respostas, resolver suas dificuldades.

O exercício que segue é uma amostragem da forma como os alunos resolveram a representação do relevo com a visão vertical.

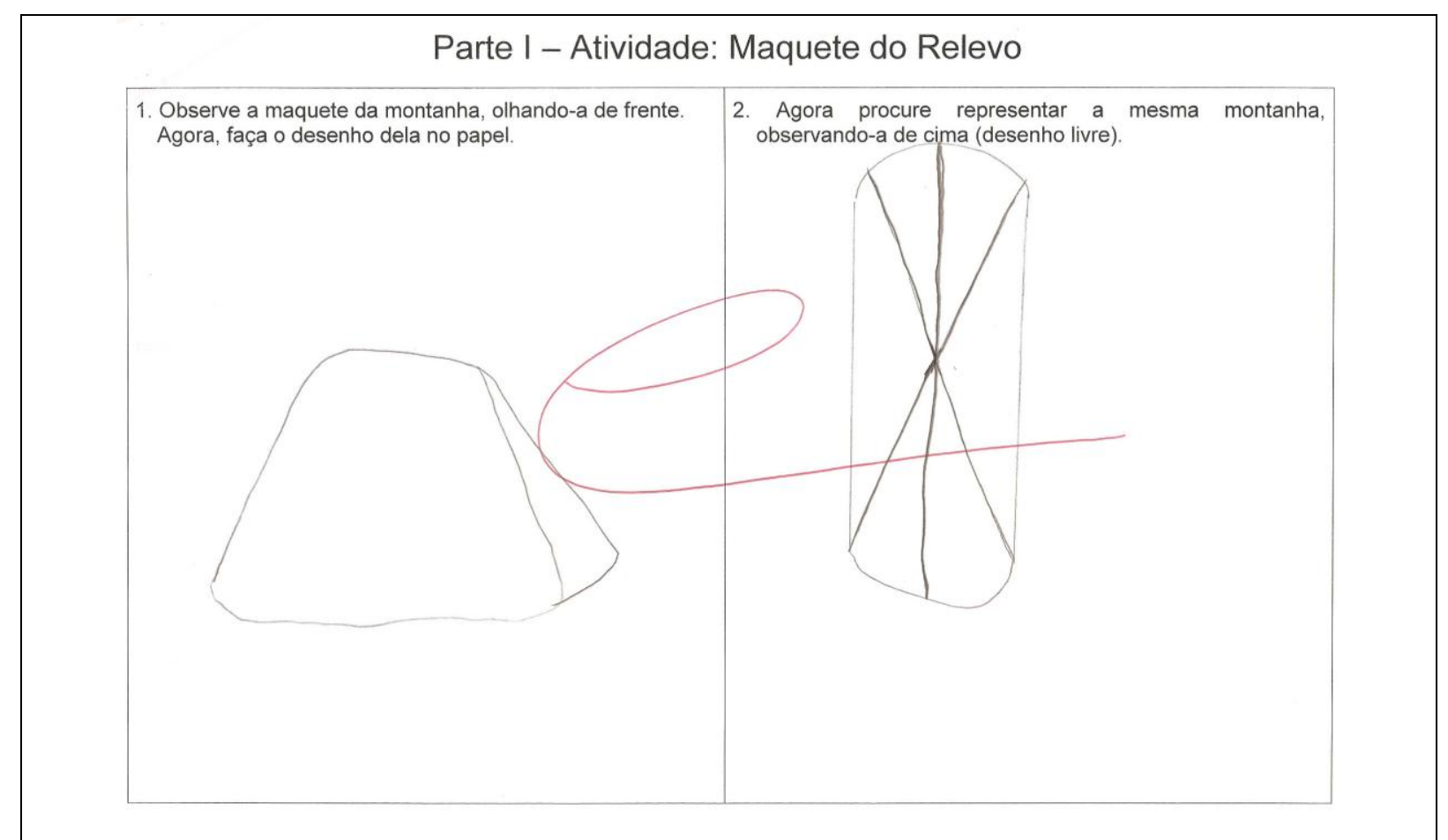

Quadro 26 - Exemplo das atividades realizadas pelos alunos para subsidiá-los na avaliação parcial do Capítulo 5 - Sorocaba: Geografia. Prancha Temática: Relevo. 5o ano E. Etapa II. Fonte: ALMEIDA, 1995. 
O passo seguinte foi construir com os alunos, "passo a passo" uma solução para a passagem da representação do relevo em forma de maquete para a sua representação no plano.

Para ajudá-los nesse processo, foi retomada a explicação de que o relevo é um fenômeno contínuo, a diferença entre "altitude" e "altura", a definição de curvas de nível. Nesse momento, os alunos perceberam que cada fatia da maquete da montanha já era a própria curva de nível. Assim, foi usada a fatia maior para representar a altitude de 0 metro, a segunda fatia para $100 \mathrm{~m}$, a terceira para 200 metros e para o cume da montanha, ficou decidido um ponto cotado de 300 metros de altitude.

Terminada a construção das curvas de nível, foi discutida a importância de uma legenda, a sua confecção em caixas empilhadas juntas pelo fato do relevo ser um fenômeno contínuo, o uso das cores hipsométricas. Para completar a representação da montanha vulcânica, foi colocado um título, a Orientação e a escala. Na figura abaixo, segue um exemplo do esforço das crianças do $5^{\circ}$ ano "E" para entenderem a representação do relevo através das curvas de nível.

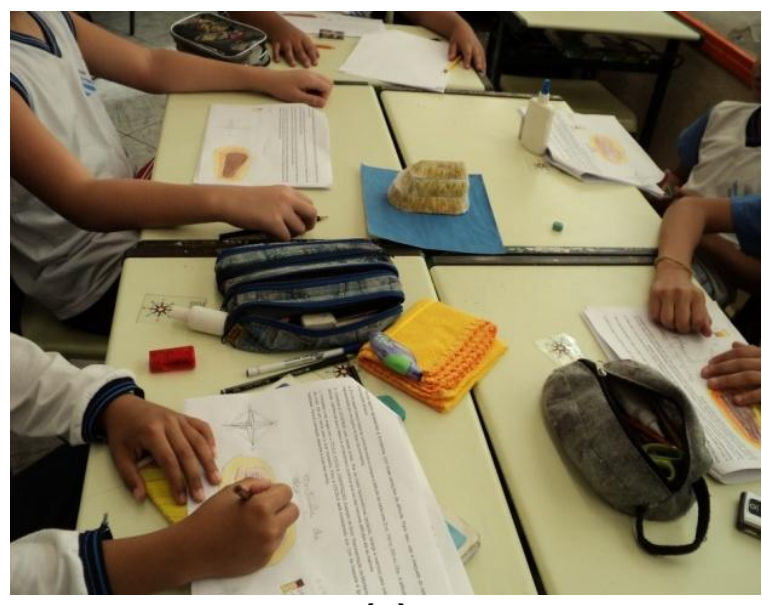

(a)

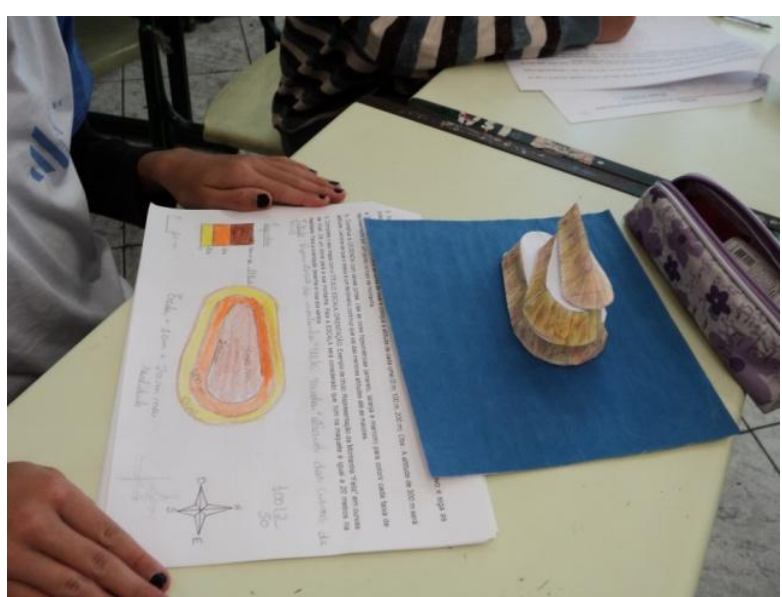

(b)

Figura 18 - Atividade em grupo dos alunos do $5^{\circ}$ ano, turma "E", envolvendo o uso de uma maquete para auxiliar na representação do relevo através das curvas de nível. (a) e (b). Fonte: a autora, 2012. 


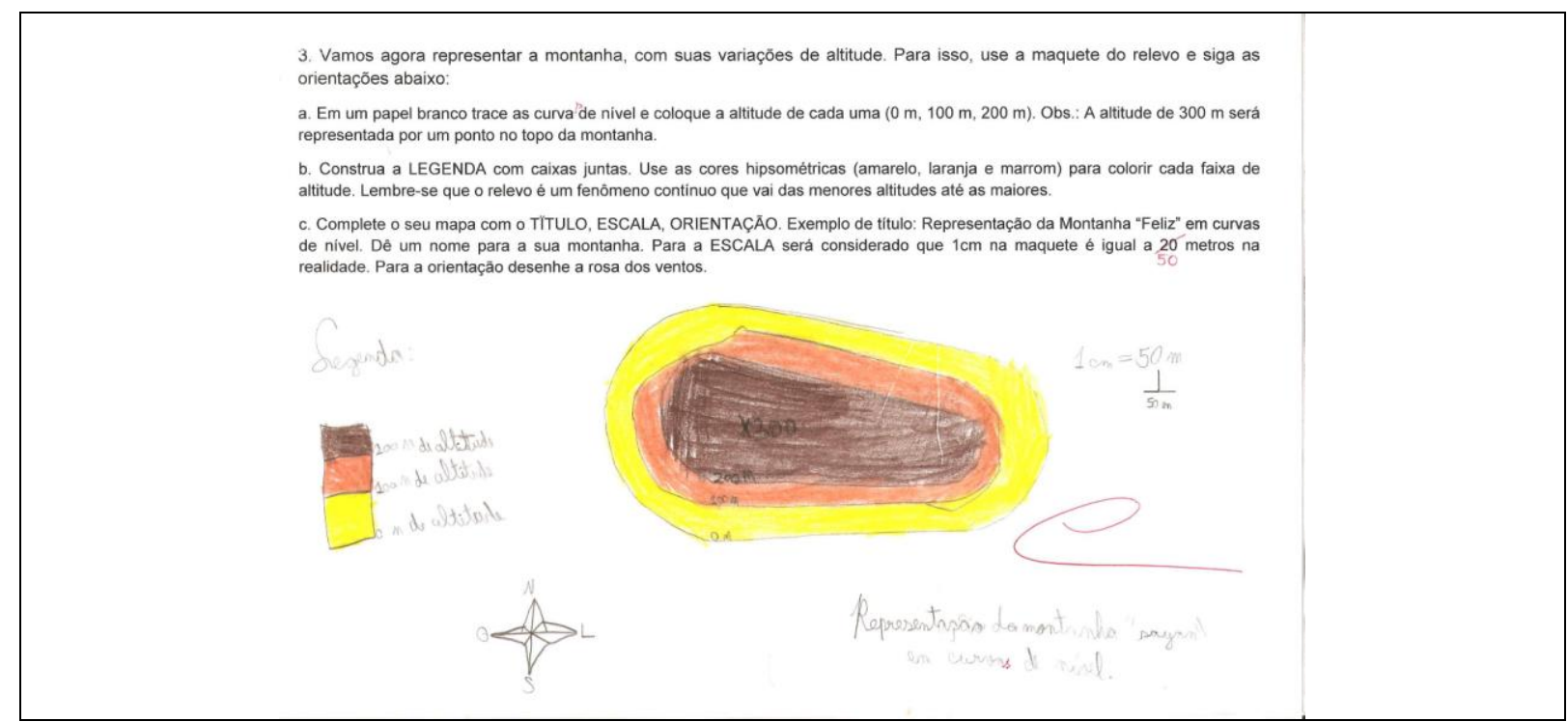

Quadro 27 - Exemplo das atividades realizadas pelos alunos para subsidiá-los na avaliação parcial do Capítulo 5 - Sorocaba: Geografia. Prancha Temática: Relevo. 5o ano E. Etapa II. Fonte: ALMEIDA, 1995.

Terminado o mapa "simplificado" do relevo da montanha, foi entregue aos alunos duas atividades (figura1 e 2 do quadro 28) para serem desenvolvidas individualmente. $\mathrm{O}$ objetivo desse momento era para que o aluno, primeiramente, conseguisse associar as formas de relevo (primeira coluna) com a sua representação gráfica (curvas de nível). No segundo momento, o aluno deveria observar as figuras e associá-las na representação correspondente, conforme exemplos abaixo. 
Parte II - Atividade: interpretando as formas de relevo

1 Faça a correspondência entre os morros e as representações corretas:
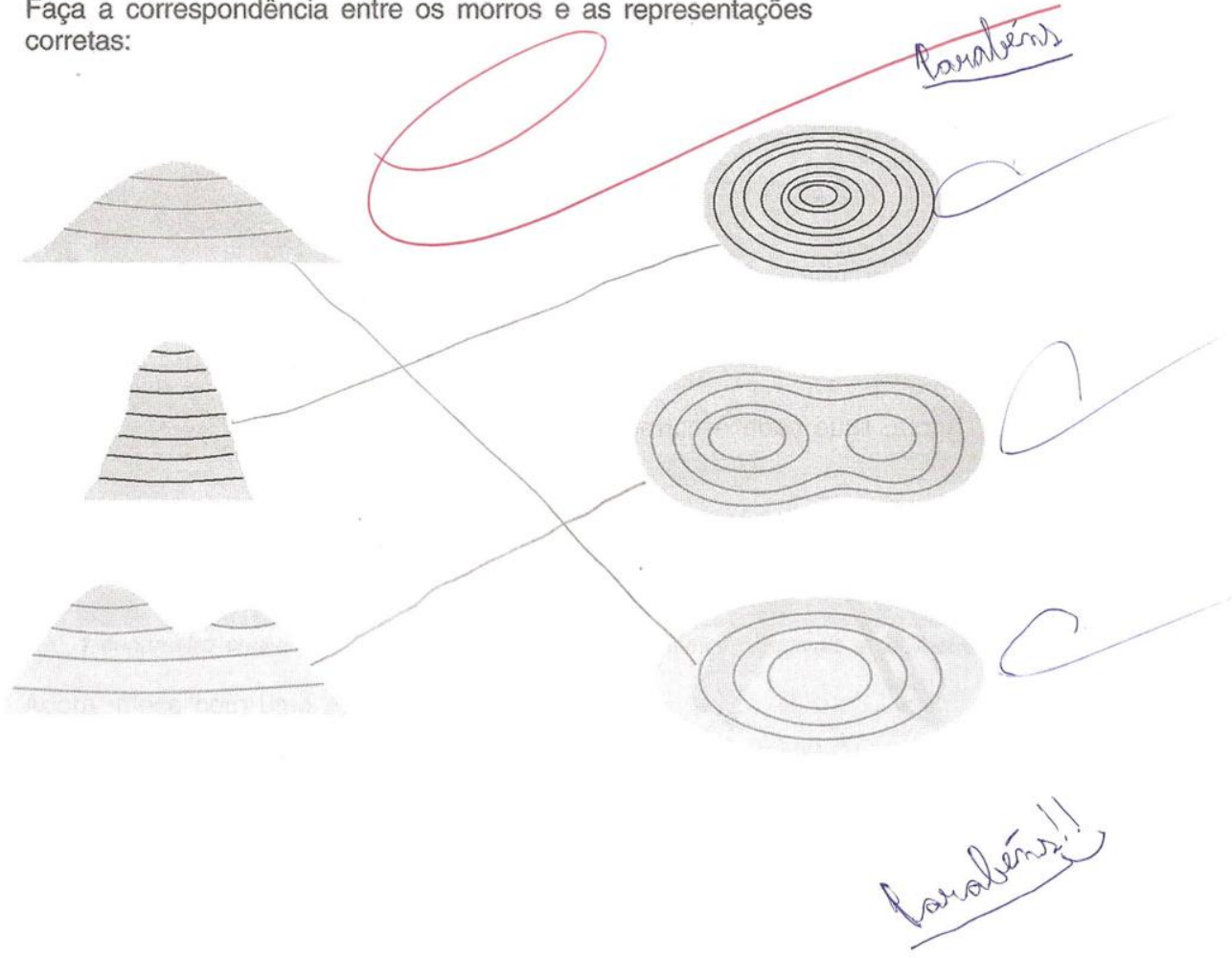

2 Observe as figuras e marque um $X$ na representação correspondente:
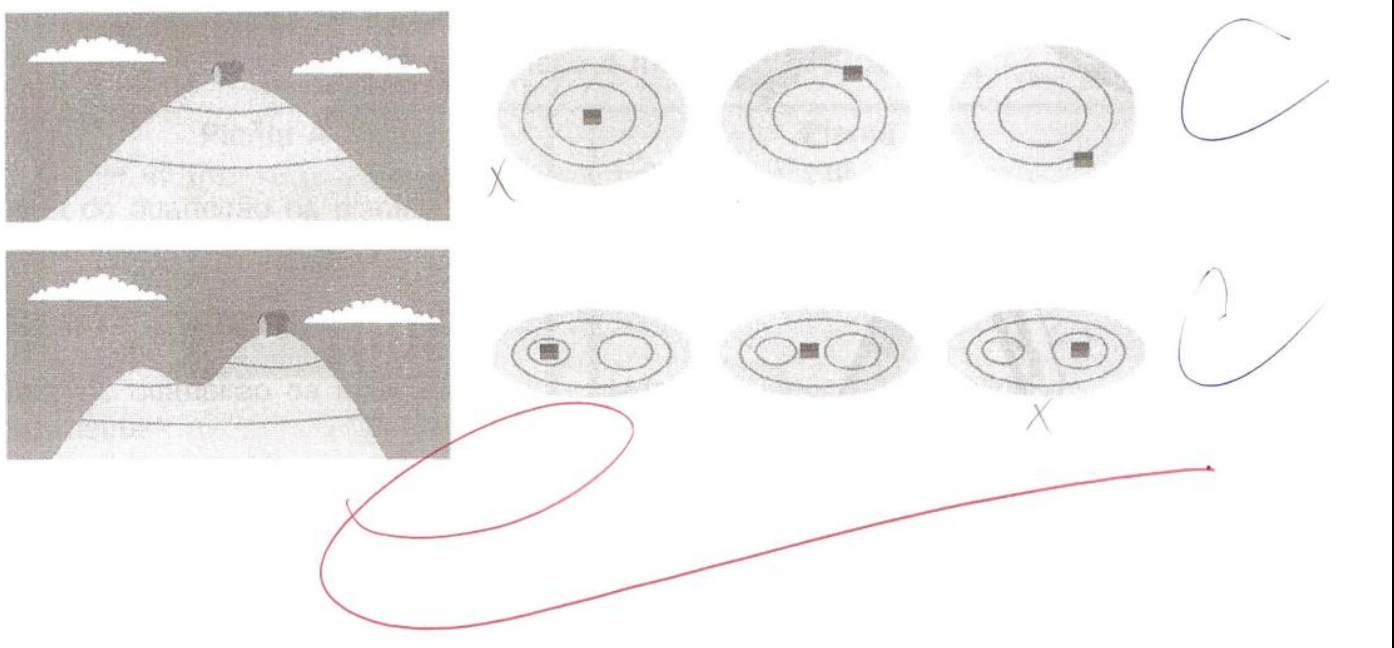

Quadro 28 - Exemplo das atividades realizadas pelos alunos para subsidiá-los na avaliação parcial do Capítulo 5 - Sorocaba: Geografia. Prancha Temática: Relevo. 5o ano E. Etapa II. Fonte: SIMIELLI, 1996. 
Entendendo que os alunos conseguiram assimilar as noções básicas sobre o relevo e sua representação através das curvas de nível, deu-se o início do estudo do Relevo do município de Sorocaba. Para esse trabalho os recursos didáticos empregados foram: fotografia aérea, mapas, maquetes, e textos do relevo de Sorocaba. As etapas seguidas foram:

- Noções elementares de mapeamento com fotografias aéreas

- O mapa topográfico

- Maquete do relevo de Sorocaba em cores hipsométricas por faixas de altitudes

- Maquete do relevo de Sorocaba com o relevo polido

- Visualização da maquete a partir de vários pontos de vista

- Mapa do relevo de Sorocaba

- Elementos do mapa: título, legenda, orientação, coordenadas geográficas e escala

Cada etapa apresentada serviu como pretexto para discussão de conceitos como: mapeamento e uso das novas tecnologias, maquetes, relevo, tipos de relevo, altitude, curvas de nível, mapa do relevo em cores hipsométricas, limites municipais, bacia hidrográfica, cabeceiras dos rios, área urbana e rural. Por fim, a caracterização do relevo de Sorocaba (terra rasgada em tupi-guarani).

Seguem figuras ilustrativas do trabalho com os alunos do $5^{\circ}$ ano "C" e "E" com as maquetes do relevo do município de Sorocaba. 


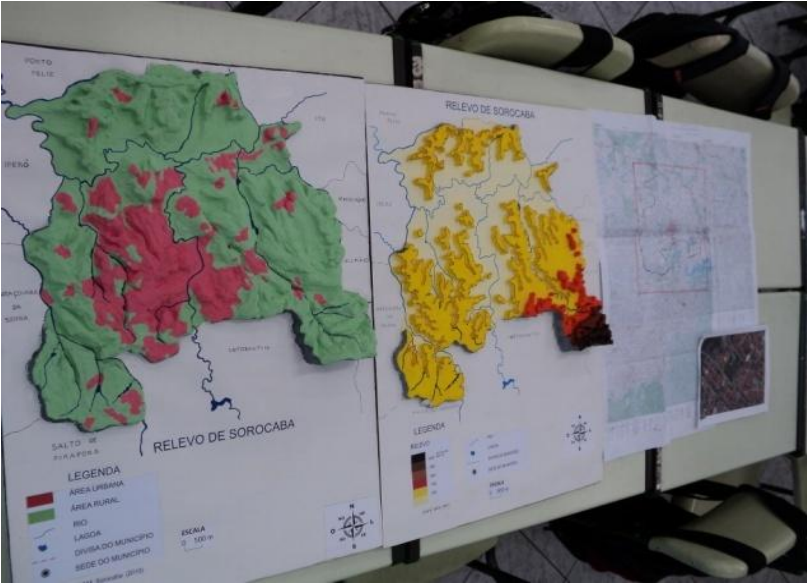

(a)

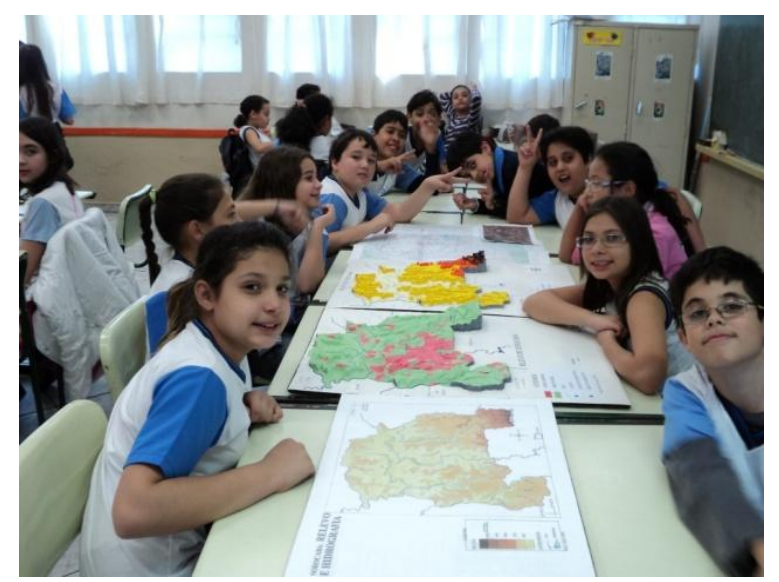

(c)

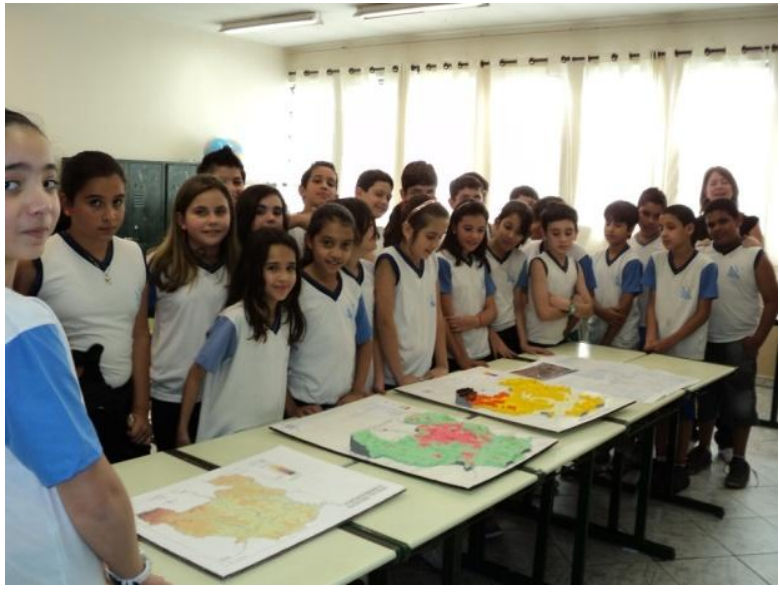

(b)

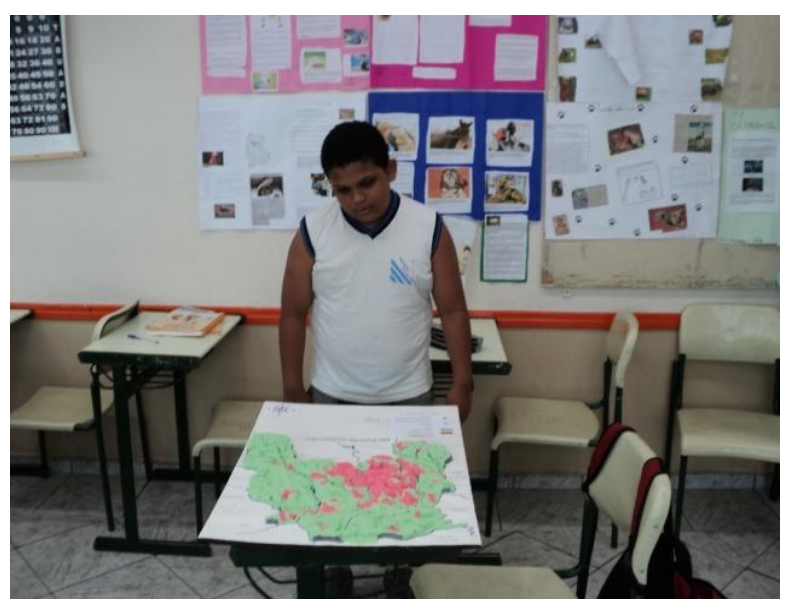

(d)

Figura 19 - Da fotografia aérea ao mapa do relevo passando por maquetes (a), (b) e (c). Aluno observando a maquete sob vários pontos de vista (d). Trabalho desenvolvido com os alunos do $5^{\circ}$ ano, turma "E". Fonte: a autora, 2012. 


\section{ETAPA III}

\section{A avaliação da prancha temática - Sorocaba: Relevo}

A avaliação da prancha temática do relevo foi individual e seguiu as etapas:

- Leitura e interpretação do texto. A primeira leitura do texto foi feita pela pesquisadora que procurou esclarecer todas as dúvidas levantadas pelos alunos. Porém, foi feita ainda uma segunda leitura individual e em silêncio.

- Aplicação de um questionário. Foi solicitado aos alunos que fizessem a leitura do mapa começando pelo título, legenda, orientação, escala e fonte. Em seguida, foi esclarecido que todas as perguntas do questionário deveriam ser respondidas apenas com base nos dados extraídos do mapa.

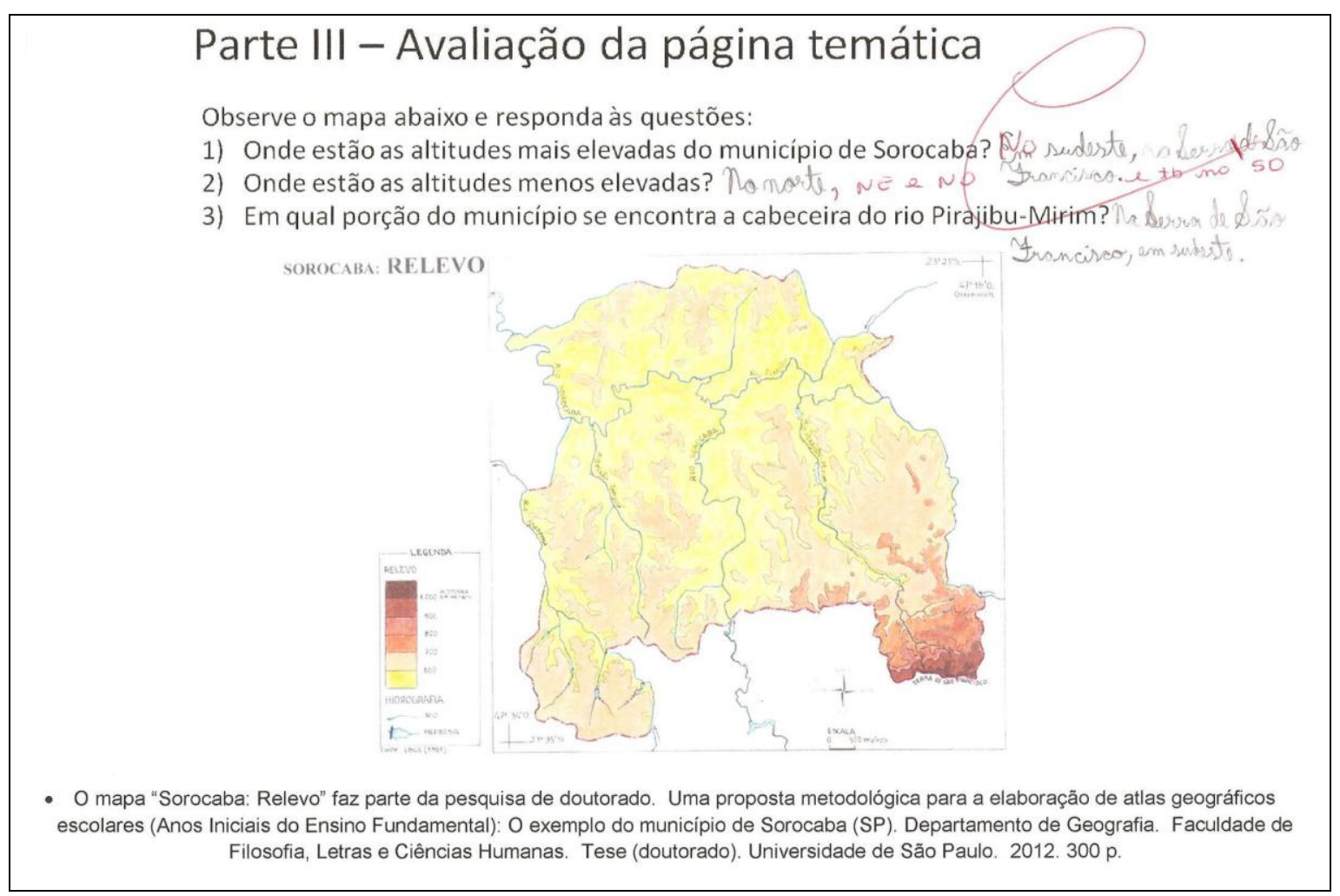

Quadro 29 - Exemplo da Avaliação realizada. Capítulo 5 - Sorocaba: Geografia. Prancha Temática: Relevo. 5a ano, turma "E”. Fonte: a autora, 2012. 


\section{Análise dos Resultados da Avaliação da Prancha Temática - SOROCABA: RELEVO - 5 ANO, turmas C e E}

Os gráficos 11 e 12 correspondem à avaliação da prancha temática "Relevo", representando o desempenho dos alunos das turmas dos 5os. anos $\mathrm{C}$ e E, em relação à sua capacidade de interpretação do texto e do mapa associado ao tema. No eixo das ordenadas, encontra-se o percentual dos alunos, enquanto que no eixo das abscissas, apresenta-se o número de questões certas. As turmas $\mathrm{C}$ e $\mathrm{E}$ possuíam 26 e 28 alunos, respectivamente.

Da análise dos gráficos 11 e 12, percebe-se que os alunos obtiveram um bom desempenho. De fato, $62 \%$ dos alunos do $5^{\circ}$. ano C e $58 \%$ dos alunos do 5․ Ano $\mathrm{E}$ acertaram mais da metade das questões propostas.

Gráfico 8

PERCENTUAL DOS ALUNOS DA TURMA DO 5 ANO C, SEGUNDO O NÚMERO DE QUESTÕES CERTAS. PRANCHA TEMÁTICA SOROCABA: RELEVO - 2012

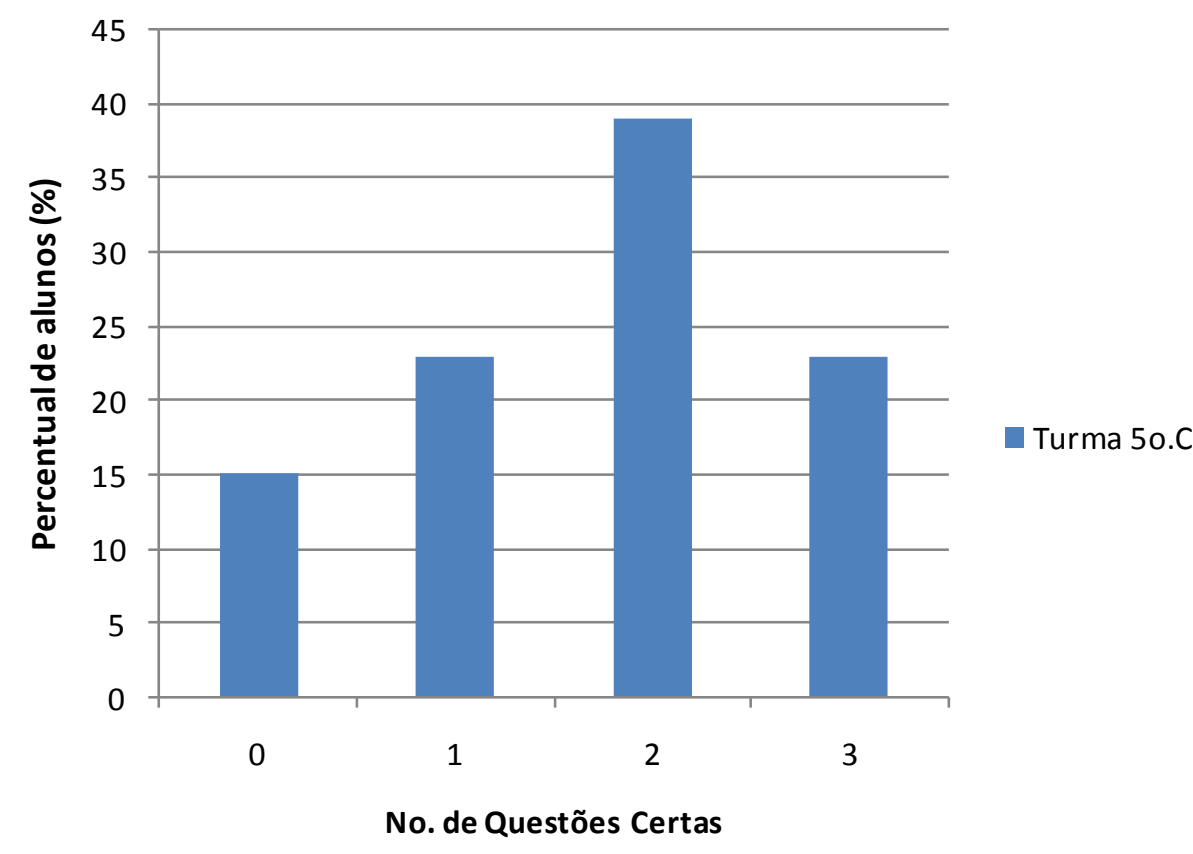

Fonte: a autora, 2012. 
Gráfico 9

PERCENTUAL DOS ALUNOS DA TURMA DO 5 ANO E, SEGUNDO O NÚMERO DE QUESTÕES CERTAS. PRANCHA TEMÁTICA SOROCABA: RELEVO - 2012

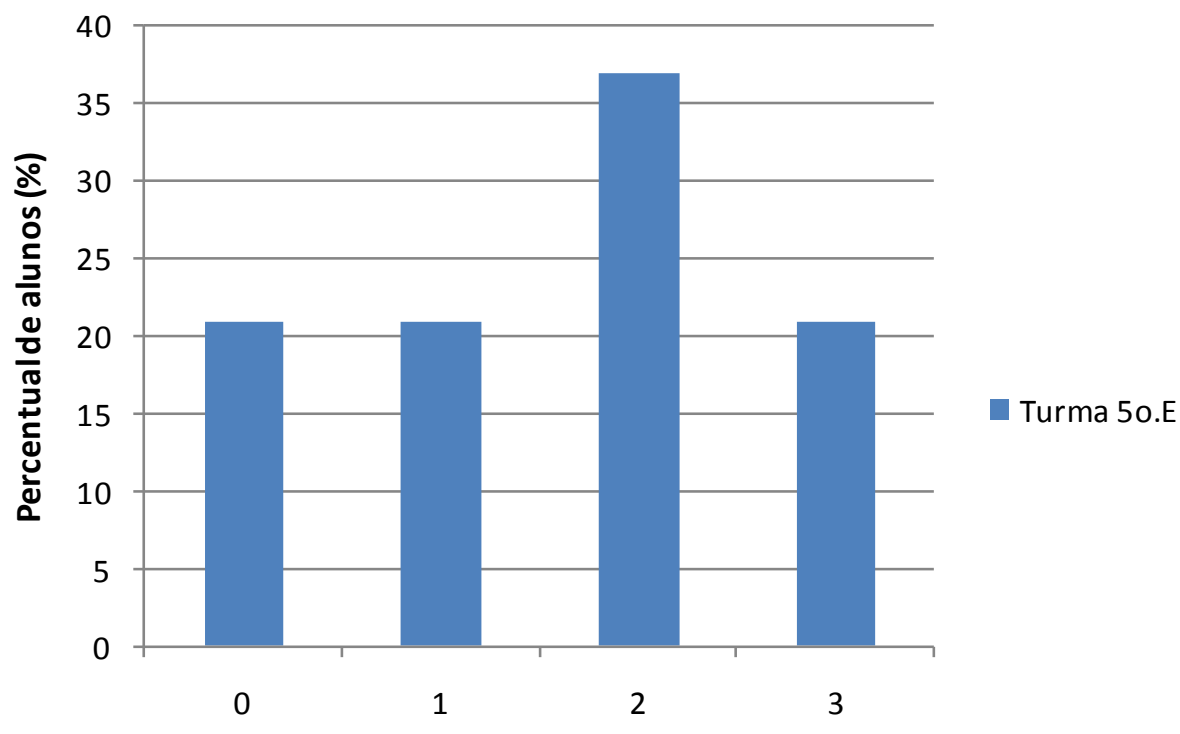

No. de Questões Certas

Fonte: a autora

Gráfico 10

PERCENTUAL DOS ALUNOS DE TODAS AS TURMAS DOS 5 ANOS, SEGUNDO O NÚMERO DE QUESTÕES CERTAS. PRANCHA TEMÁTICA - SOROCABA: RELEVO - 2012

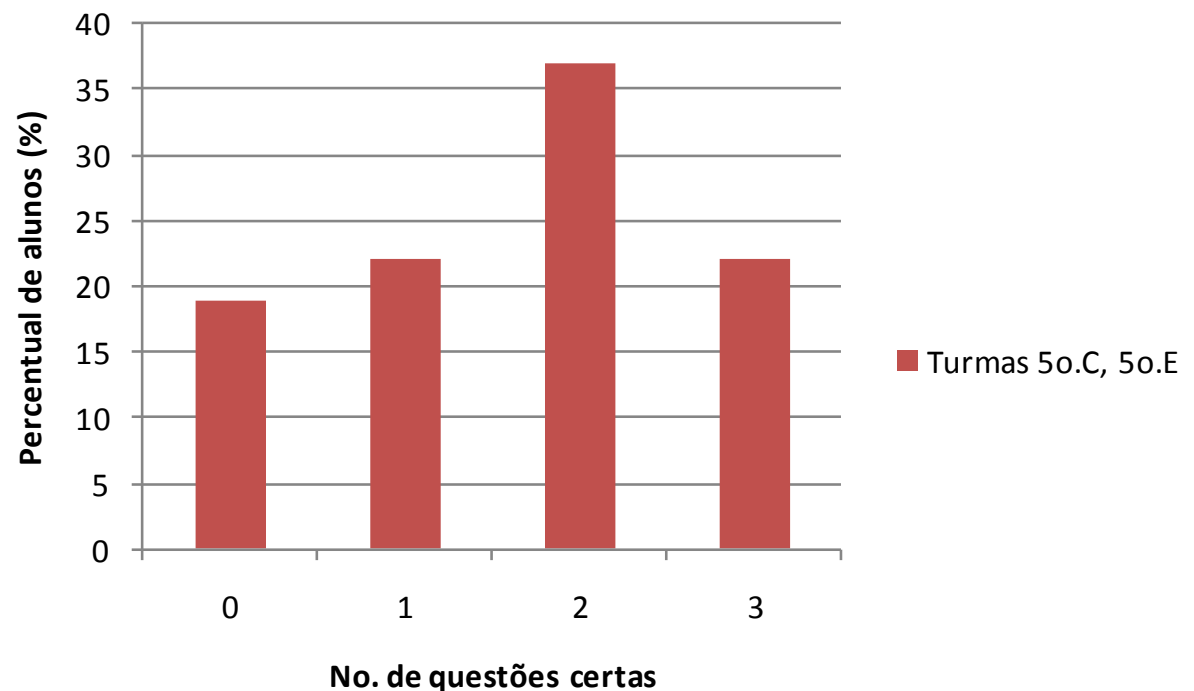

Fonte: a autora 


\subsection{Clima}

Modelo da proposta metodológica para avaliação parcial do CAPÍTULO V SOROCABA: GEOGRAFIA. PRANCHA TEMÁTICA - SOROCABA: CLIMA - 5은 ano, turma "E"

\section{Proposta metodológica para avaliação parcial do CAPÍTULO 5 - Sorocaba:} GEOGRAFIA - Prancha Temática - SOROCABA: CLIMA. 5o ano E. Escola Estadual Baltazar Fernandes.

Professora: Eliane Rodrigues - 5ํㅡ (tarde)

\begin{tabular}{|c|c|c|}
\hline ATIVIDADES & CONTEÚDOS & O QUE SE ESPERA DO ALUNO \\
\hline $\begin{array}{l}\text { ETAPA I } \\
\text { Construção de um } \\
\text { gráfico de coluna }\end{array}$ & $\begin{array}{l}\text {.Coleta de dados } \\
\text {. O que é um } \\
\text { gráfico? } \\
\text {.Tipos de gráficos } \\
. \text { O uso de gráficos } \\
\text { em mapas }\end{array}$ & $\begin{array}{l}\text { Que o aluno consiga representar } \\
\text { dados numéricos através de } \\
\text { gráficos. } \\
\text { Que o escolar passe a conhecer } \\
\text { os diferentes tipos de gráfico }\end{array}$ \\
\hline $\begin{array}{c}\text { ETAPA II } \\
\text { Análise e } \\
\text { interpretação dos } \\
\text { gráficos da } \\
\text { pluviometria e da } \\
\text { temperatura de } \\
\text { Sorocaba }\end{array}$ & $\begin{array}{c}\text { O que é clima? } \\
\text { Diferença entre } \\
\text { Clima e Tempo } \\
\text {. O gráfico da } \\
\text { pluviometria. } \\
\text {. O gráfico da } \\
\text { temperatura } \\
\text {. As estações do } \\
\text { ano (o movimento } \\
\text { de translação da } \\
\text { Terra) }\end{array}$ & $\begin{array}{c}\text { Que o aluno perceba a relação } \\
\text { entre os dados pluviométricos e de } \\
\text { temperatura mensais do município } \\
\text { de Sorocaba com as estações do } \\
\text { ano. }\end{array}$ \\
\hline $\begin{array}{l}\text { ETAPA III } \\
\text { Avaliação da } \\
\text { Prancha temática } \\
\text { Sorocaba: CLIMA }\end{array}$ & $\begin{array}{l}\text { Iniciação } \\
\text { Cartográfica: } \\
\text { Localização pela } \\
\text { Orientação e } \\
\text { Escala } \\
\text { Título } \\
\text { Legenda } \\
\text { Orientação } \\
\text { Fonte }\end{array}$ & $\begin{array}{c}\text { TEXTO E GRÁFICOS: Que fique } \\
\text { claro para o aluno perceber que o } \\
\text { clima se apresenta como um } \\
\text { fenômeno contínuo. Que clima é } \\
\text { diferente de tempo. Por fim, ele } \\
\text { tenha noções básicas da } \\
\text { classificação do clima de } \\
\text { Sorocaba. } \\
\text { MAPA: Que o aluno consiga } \\
\text { Identificar o clima predominante } \\
\text { em uma dada porção do município } \\
\text { de Sorocaba. }\end{array}$ \\
\hline
\end{tabular}

Quadro 30 - Proposta metodológica para avaliação parcial do Capítulo 5 - Sorocaba: Geografia - Prancha Temática - Sorocaba: Clima. 5ํano. Fonte: a autora, 2012. 
Apresentação das atividades executadas pelos alunos do $5^{\circ}$ ano

\section{PRANCHA TEMÁTICA - SOROCABA: CLIMA}

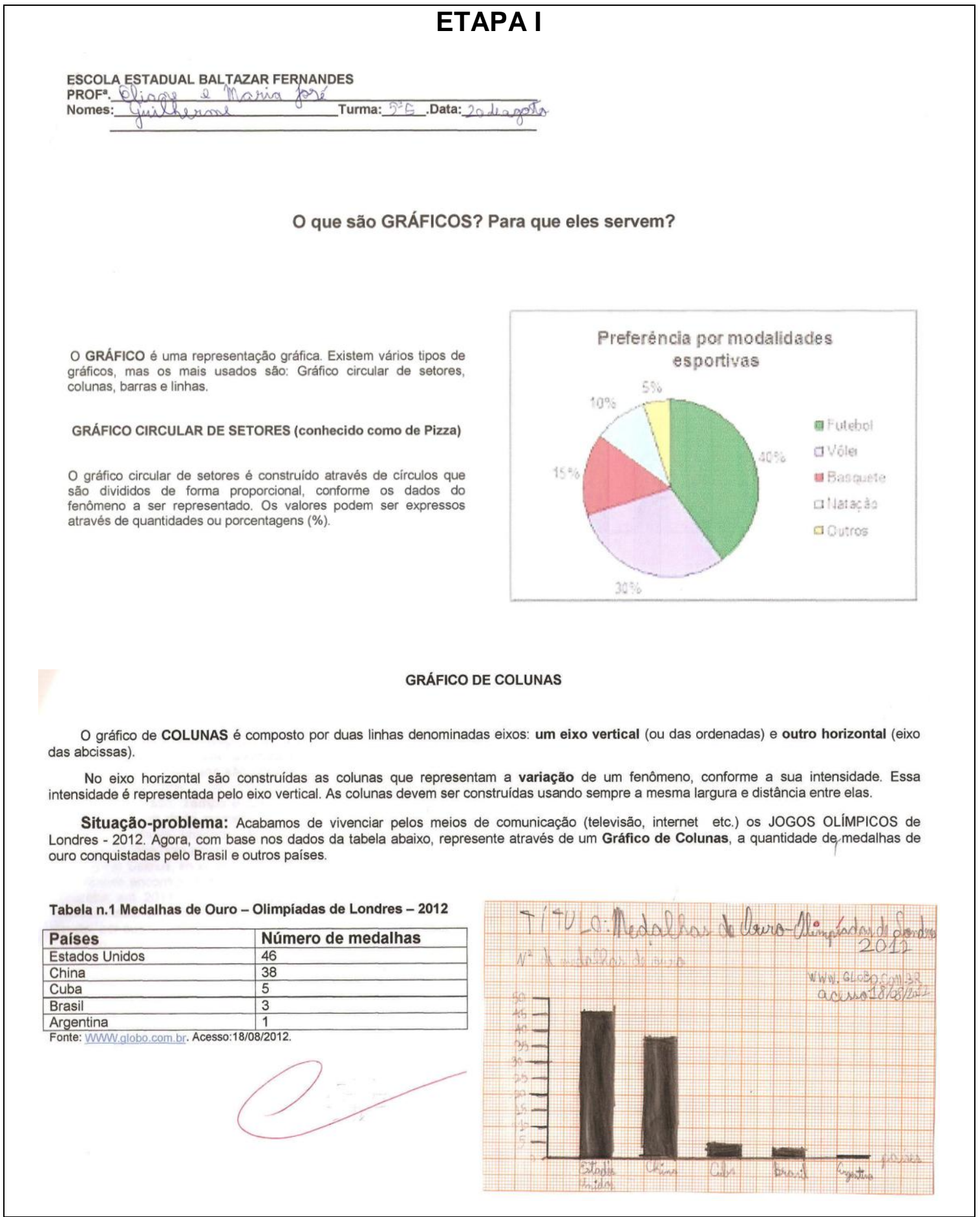

Quadro 31 - Exemplo das atividades realizadas pelos alunos para subsidiá-los na avaliação parcial do Capítulo 5 - Sorocaba: Geografia. Prancha Temática - Sorocaba: Clima. 5ํao. Etapa I. Fonte: a autora, 2012. 


\section{ETAPA II}

\section{SOROCABA: CLIMA}

\begin{abstract}
O termo Clima diz respeito a como percebemos a sucessão dos tipos de tempo. Assim, dizemos que as estaçöes do ano ou mesmo os dias da semana são chuvosos, quentes, abafados, com vento, frios ou úmidos.

Por outro lado, Tempo é como percebemos as condições da atmosfera em um dado momento e lugar. $\mathrm{O}$ tempo é medido pela temperatura, chuva, umidade, dentre outros fenômenos. Dizemos, por exemplo, que hoje amanheceu com um tempo bom, temperatura de 26 graus Celsius, seco, sem chuva.

Abaixo encontra-se o gráfico da pluviosidade do Município de Sorocaba em 2011. Neste gráfico, percebe-se que o mês mais chuvoso neste ano foi o de fevereiro, durante o verăo. 0 mês de agosto, por sua vez, registrou a menor quantidade de chuva durante o inverno.
\end{abstract}

Pluviometria do município de Sorocaba - ano 2011

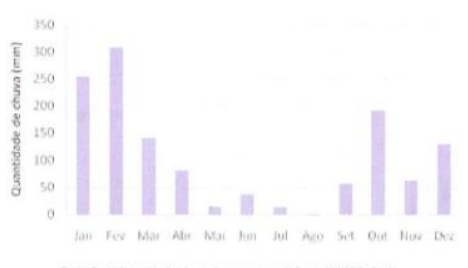

O gráfico n.2 da temperatura do município de Sorocaba - 2011 indica que fevereiro foi o mês que apresentou a temperatura mais alta, enquanto que em junho registrou-se a mais baixa.

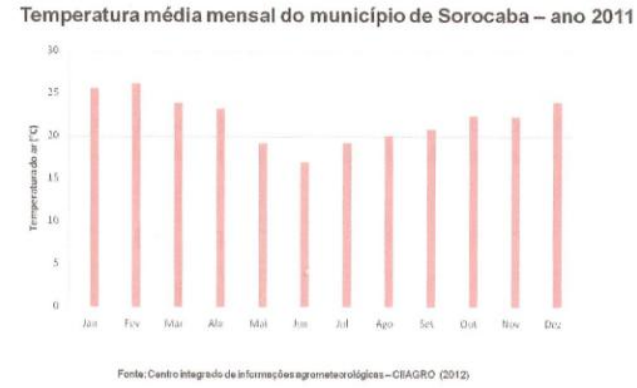

Se compararmos os dados do gráfico n. 1 e 2, podemos pensar, que o clima de Sorocaba caracteriza-se como chuvoso no verăo, apresentando temperaturas altas; e seco e frio no inverno, de forma geral.

0 fato é que o municipio de Sorocaba situa-se entre duas grandes zonas climáticas que passam pelo estado de São Paulo e coincidem com a passagem do Trópico de Capricórnio.

Uma delas corresponde à zona dos climas controlados pelas massas de ar equatoriais (com calor quase $o$ ano todo e chuvas) $e$ tropicais (com calor mais no verão e estação das chuvas bem marcada).

A outra zona é a dos climas controlados pelas massas de ar tropicais e polares, as que trazem um ar bastante frio, proveniente das frentes frias, mudando quase que repentinamente o tempo, principalmente no inverno.

\section{AVALIAÇÃO: Gráficos}

SOROCABA: Chuva e Temperatura em gráficos

1. Observe o gráfico n.1 abaixo e responda as questões: Pluviometria do municipio de Sorocaba - ano 2011
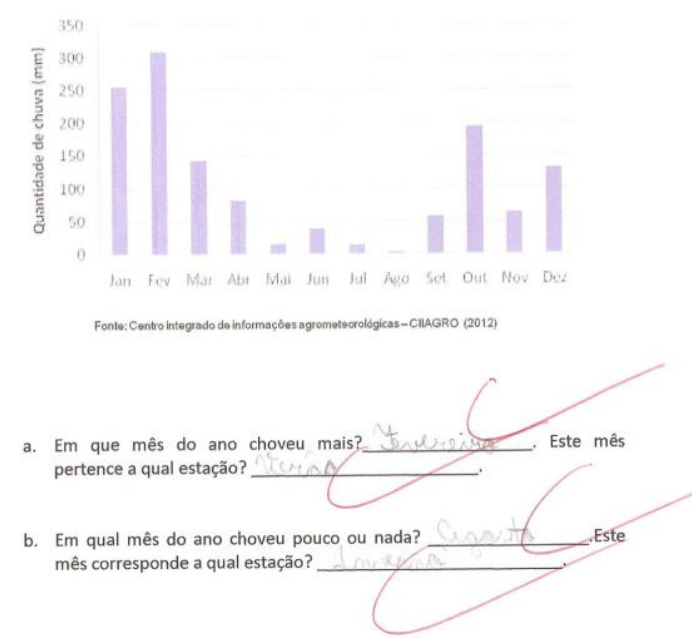

2. Agora, analise o gráfico $n .2$ e responda as questöes abaixo: Temperatura média mensal do município de Sorocaba - ano 2011

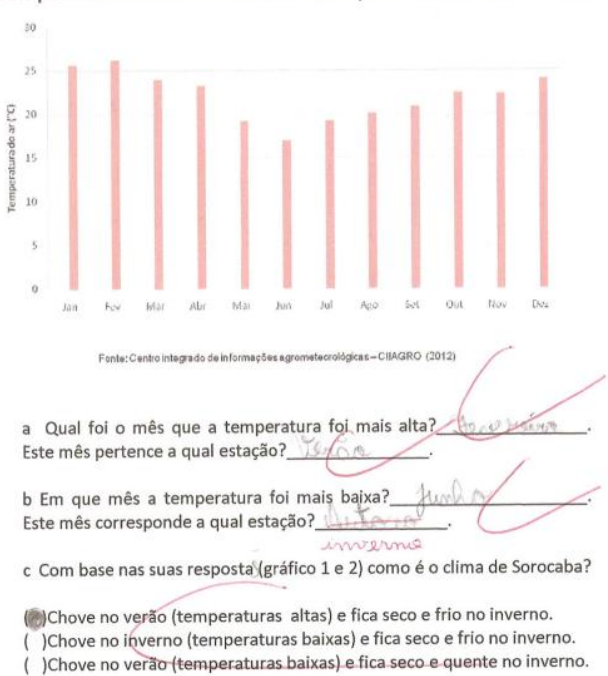

Quadro 32 - Exemplo das atividades realizadas pelos alunos para subsidiá-los na avaliação parcial do Capítulo 5 - Sorocaba. Prancha Temática - Sorocaba: Clima. 5oano. Etapa II. Fonte: a autora, 2012. 


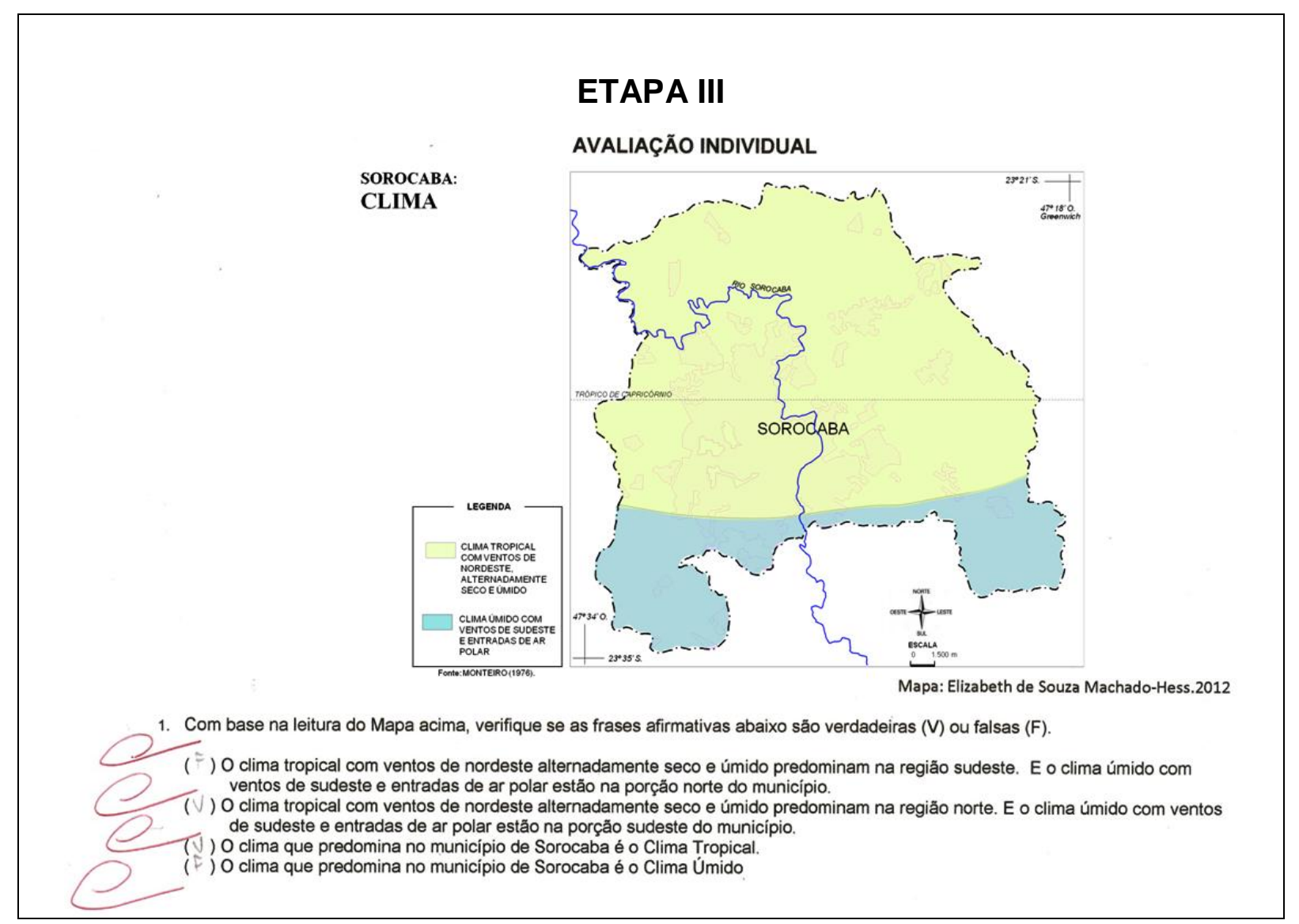

Quadro 33 - Exemplo da Avaliação realizada. Capítulo 5 - Sorocaba: Geografia. Prancha Temática Sorocaba: Clima. 5 ano, turma "E". Etapa III. Fonte: a autora, 2012.

\section{Análise dos Resultados da Avaliação da Prancha Temática - Sorocaba: Clima - 5 ano, turma $E$}

Os gráficos 13 e 14 correspondem à avaliação da prancha temática "Clima", representando o desempenho dos alunos da turma do 50 . ano $\mathrm{E}$, em relação à sua capacidade de interpretação de gráficos associados à precipitação (chuva) e a temperatura em Sorocaba. No eixo das ordenadas, encontra-se o percentual dos alunos, enquanto que no eixo das abscissas, apresenta-se o número de questões certas. Participaram da avaliação 22 alunos desta turma. 
Gráfico 11

PERCENTUAL DOS ALUNOS DA TURMA DO 5 ANO E, SEGUNDO O NÚMERO DE QUESTÕES CERTAS SOBRE O GRÁFICO DA PLUVIOMETRIA DE SOROCABA. PRANCHA TEMÁTICA - SOROCABA: CLIMA - 2012

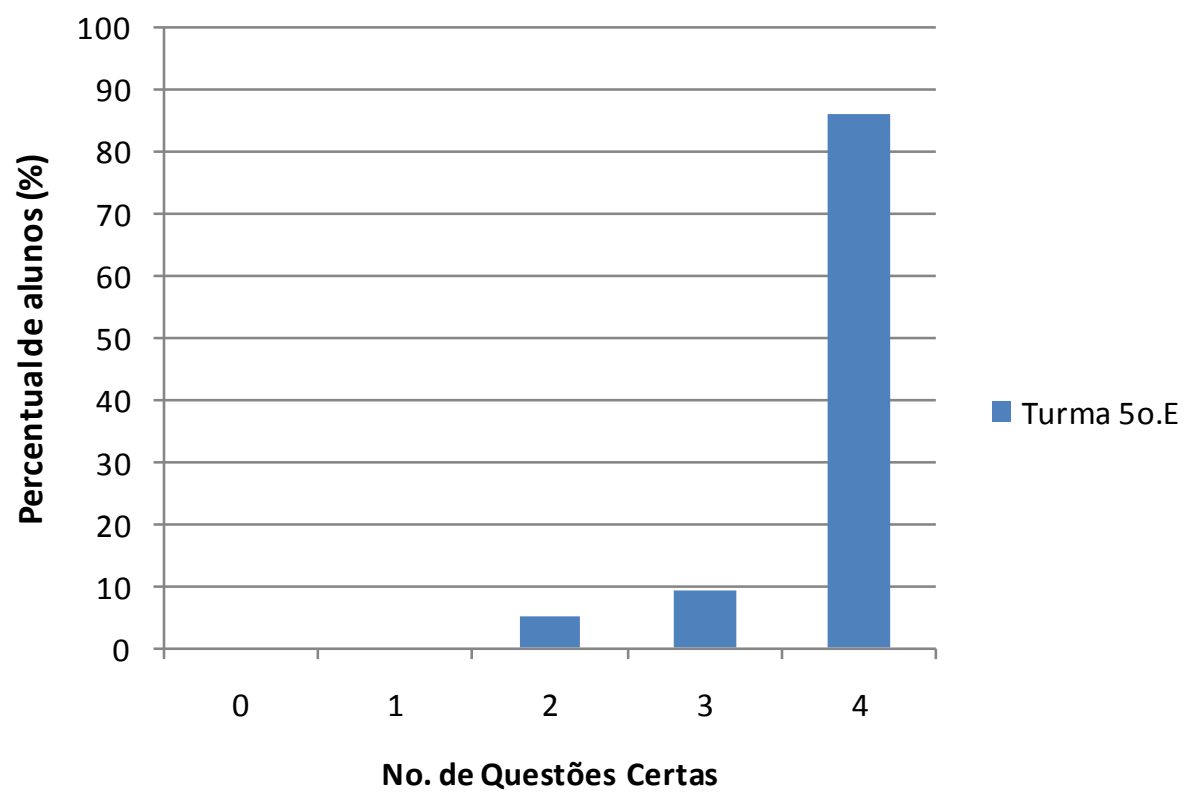

Fonte: a autora, 2012.

Gráfico 12

PERCENTUAL DOS ALUNOS DA TURMA DO 5 ANO E, SEGUNDO O NÚMERO DE QUESTÕES CERTAS SOBRE O GRÁFICO DA TEMPERATURA DE SOROCABA. PRANCHA TEMÁTICA SOROCABA: CLIMA - 2012

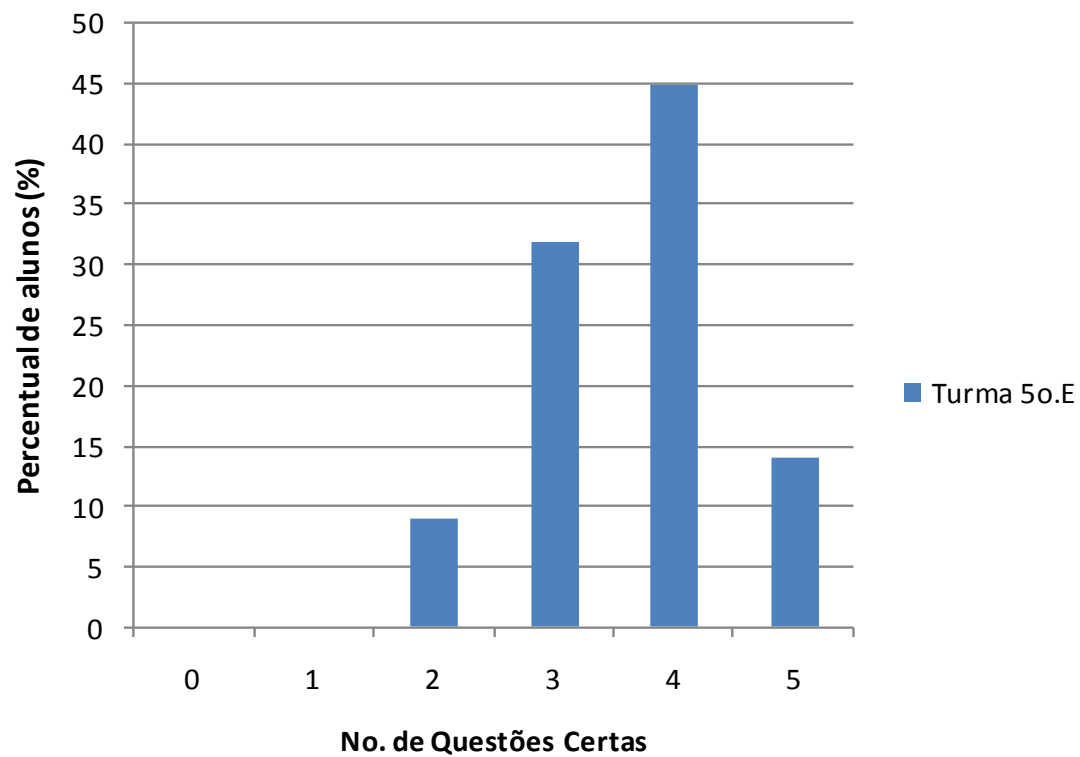

Fonte: a autora, 2012. 
Da análise dos gráficos 13 e 14, observa-se que os alunos obtiveram um desempenho muito bom, sendo que o gráfico da chuva em Sorocaba foi corretamente interpretado por $90 \%$ dos alunos, enquanto que o da temperatura, $90 \%$ dos alunos acertaram mais da metade das questões propostas.

O gráfico 15 corresponde à avaliação da prancha temática "Clima", representando o desempenho dos alunos da turma do 50 . ano $E$, em relação à sua capacidade de interpretação do mapa associado ao Clima em Sorocaba. No eixo das ordenadas, encontra-se o percentual dos alunos, enquanto que no eixo das abscissas, apresenta-se o número de questões certas. Participaram da avaliação 26 alunos desta turma.

$\mathrm{Da}$ análise do gráfico15, percebe-se que os alunos obtiveram um desempenho insatisfatório. De fato, o gráfico 15 indica que mais de $50 \%$ dos alunos acertaram menos da metade das questões propostas.

Gráfico 13

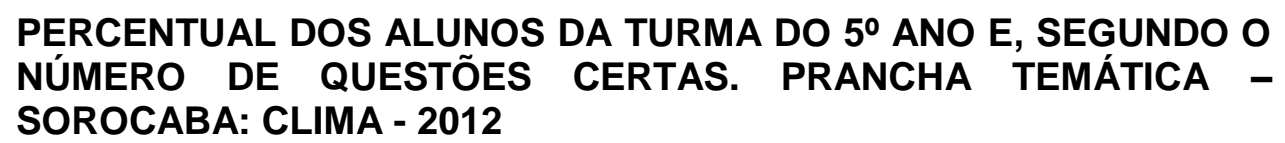
SOROCABA: CLIMA - 2012

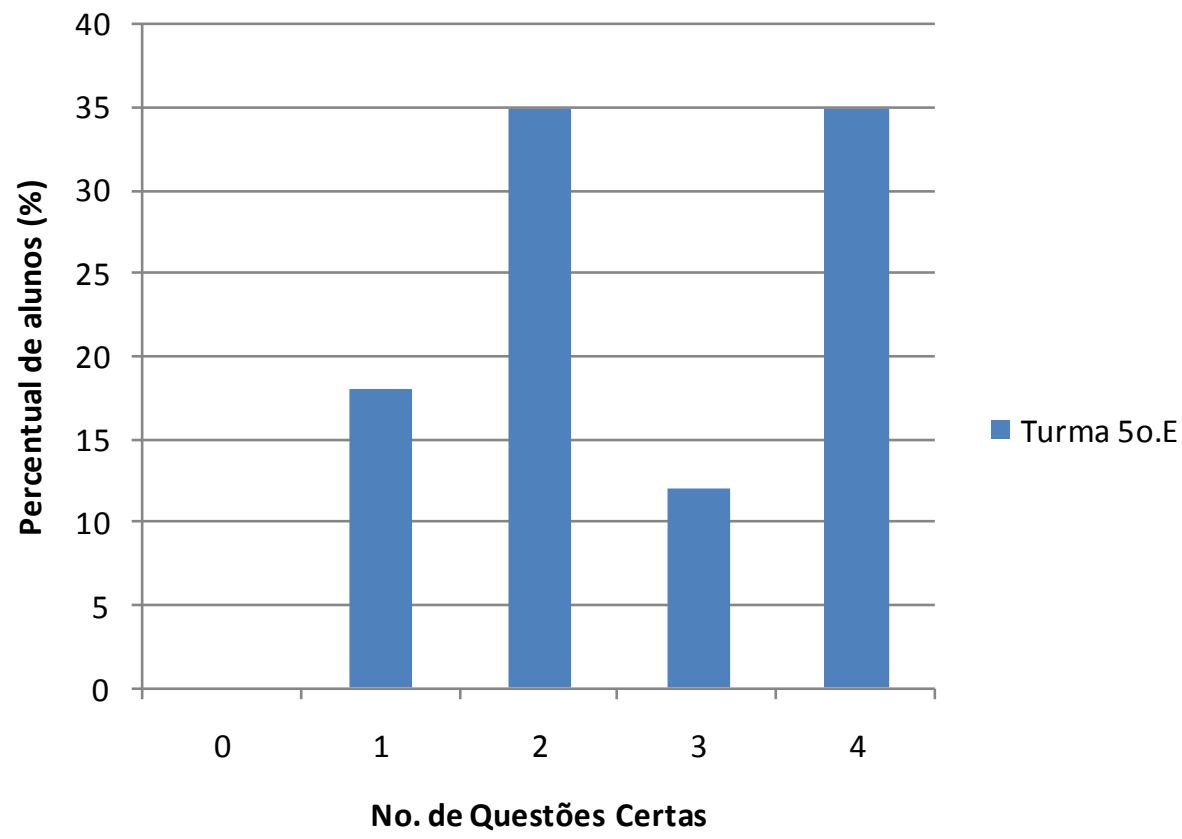

Fonte: a autora, 2012. 


\subsubsection{3 Área urbana e área rural}

Modelo da Proposta metodológica para avaliação parcial do CAPÍTULO 5 SOROCABA: GEOGRAFIA. PRANCHA TEMÁTICA - SOROCABA: ÁREA URBANA E ÁREA RURAL - 5 Ano.

Proposta metodológica para avaliação parcial do CAPÍTULO 5 Sorocaba: GEOGRAFIA. Prancha Temática - SOROCABA: ÁREA URBANA E ÁREA RURAL, 5 ano E. Escola Estadual Baltazar Fernandes. Professora: Eliane Rodrigues $-5^{\circ}$ E (tarde)

\begin{tabular}{|c|c|c|}
\hline ATIVIDADES & CONTEÚDOS & O QUE SE ESPERA DO \\
ALUNO
\end{tabular}

Quadro 34 - Proposta metodológica para avaliação parcial do Capítulo 5 - Sorocaba: Geografia. Prancha Temática - Sorocaba: área urbana e área rural, 5ำ ano. Fonte: a autora, 2012. 


\section{Apresentação das atividades executadas pelos alunos}

\section{PRANCHA TEMÁTICA - SOROCABA: ÁREA URBANA E ÁREA RURAL}

\section{ETAPA I}

\section{SOROCABA: ÁREA URBANA E ÁREA RURAL}

\begin{abstract}
O município de Sorocaba é composto por uma área urbana e outra rural.

Área urbana é a porção do território que conta com residências, estabelecimentos comerciais, escolas, hospitais, bancos etc. Com base no mapa, a área urbana de Sorocaba está localizada mais para a parte centro-sul do município. Conta com uma rede viária, ferroviária e ciclovia. Mais ao nordeste é cortado pela Rodovia Castelo Branco, da qual sai a entrada para Sorocaba por meio da Rodovia Senador José Ermírio de Moraes (Castelinho) e ao sul, pela via Raposo Tavares. Cerca de $98 \%$ dos sorocabanos vivem na área urbana.
\end{abstract}

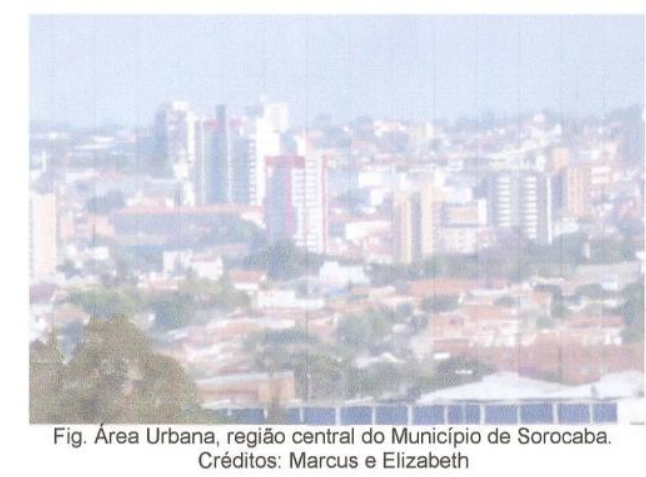

Área Rural é destinada às atividades econômicas voltadas para a agricultura, criação de gado etc. 0 entorno da área urbana de Sorocaba é considerado área rural que é formada por fazendas, chácaras, sítios e, ao longo da Castelinho está se estabelecendo uma Zona Industrial

Encontra-se ocupada predominantemente por áreas com culturas e reflorestamento, além de incluir espaços com remanescentes de mata ciliar ao longo dos rios, floresta e cerrado. Completa a paisagem áreas de campos com vegetação que brotou após a devastação da vegetacăo natural ou depois do abandono de culturas, ou pastagens. E uma região bem servida por uma série de . $6,4 \%$ da população total do município de Sorocaba.

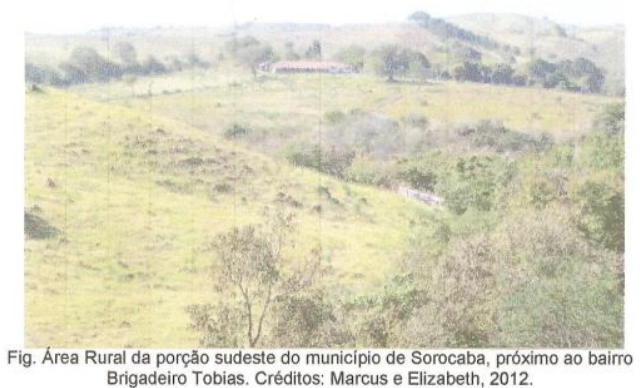

Assim, se na área urbana identificamos questōes como poluição sonora, do ar, do solo, dos rios, poucas áreas verdes etc. No campo, temos questōes como queimadas, poluicão do solo com insumos agrícolas, desmatamento etc, causando danos à saúde do ser humano e do ambiente.

\section{AVALIAÇÃO INDIVIDUAL}

1. Leia o texto com atenção, observe as figuras que há nele para responder as questões abaixo:

a Que elementos criados pelos seres humanos você observa na figura 1? Prédios, casas, folv icon,
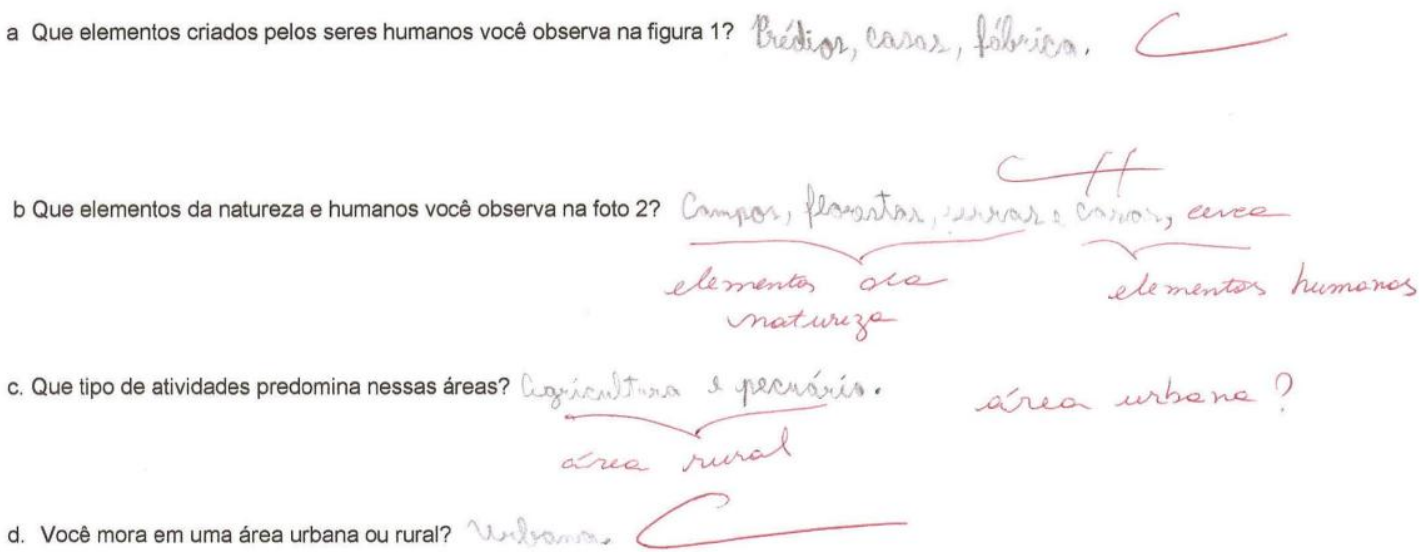

e. Quais as atividades econômicas que predominam na área em que você mora? Comén cina.

Quadro 35 - Exemplo da atividade realizada. Capítulo 5 - Sorocaba: Geografia. Prancha Temática Sorocaba: Área Urbana e Área Rural. 5ªno, turma “E”. Etapa I. Fonte: a autora, 2012. 


\section{ETAPA II}

2. Com base no mapa abaixo, responda as questões:

SOROCABA:

ÁREA URBANA E

RURAL
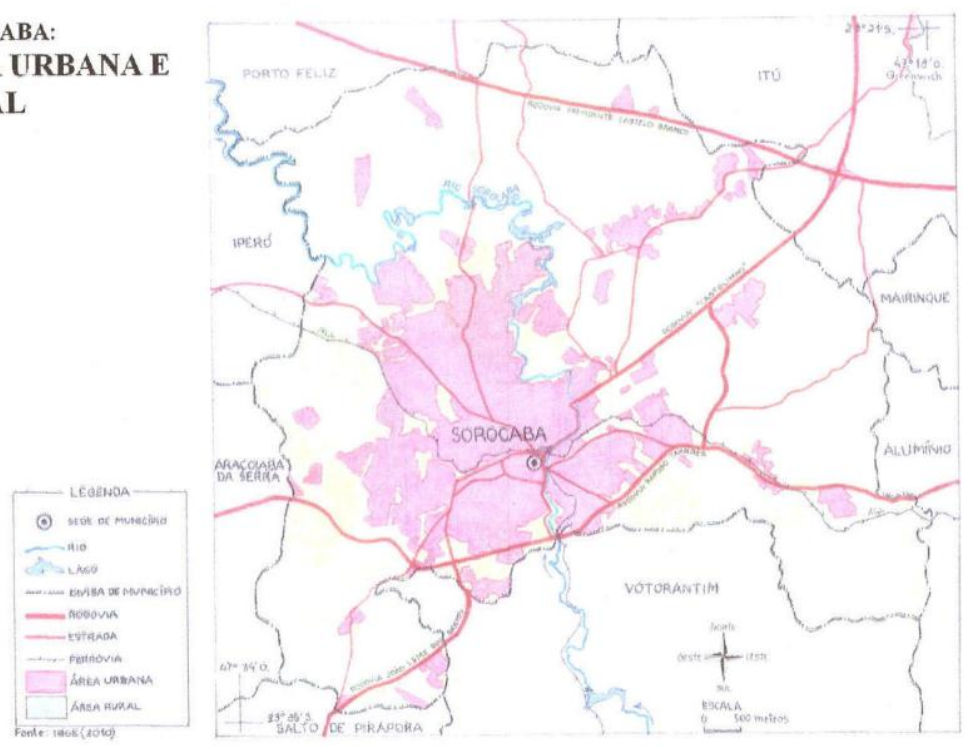

Mapa: Elizabeth de Souza Machado-Hess

1. Qual área predomina no município de Sorocaba?

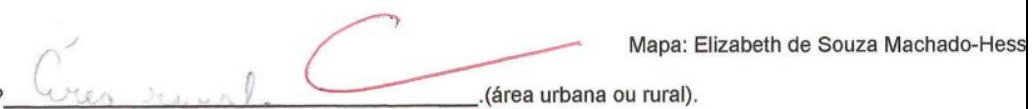

2. Em qual porção do município a região mais urbanizada está localizada?

3. Em qual direção do município a área urbana de Sorocaba se aproxima mais dos seus limites?

Quadro 36 - Exemplo da atividade realizada. Capítulo 5 - Sorocaba: Geografia. Prancha Temática Sorocaba: Área Urbana e Área Rural. 5 ano, turma "E". Etapa II. Fonte: a autora, 2012.

\section{Análise dos Resultados da Avaliação Prancha Temática - SOROCABA: ÁREA URBANA E ÁREA RURAL - 5ำ ano, turma E}

Os gráficos 16 e 17 correspondem à avaliação da prancha temática "Área Urbana e Rural", representando o desempenho dos alunos da turma do 5o. ano E, em relação à sua capacidade de interpretação do texto e do mapa associado ao tema. No eixo das ordenadas, encontra-se o percentual dos alunos, enquanto que 
no eixo das abscissas, apresenta-se o número de questões certas. Participaram da avaliação 26 alunos desta turma.

Da análise dos gráficos 16 e 17, percebe-se que os alunos obtiveram um desempenho insatisfatório. De fato, o gráfico 17 indica que mais de $60 \%$ dos alunos acertaram menos da metade das questões propostas.

Gráfico 14

PERCENTUAL DOS ALUNOS DA TURMA DO 5 ANO E, SEGUNDO O NÚMERO DE QUESTÕES CERTAS SOBRE O TEXTO DA PRANCHA TEMÁTICA: ÁREA URBANA E ÁREA RURAL - 2012

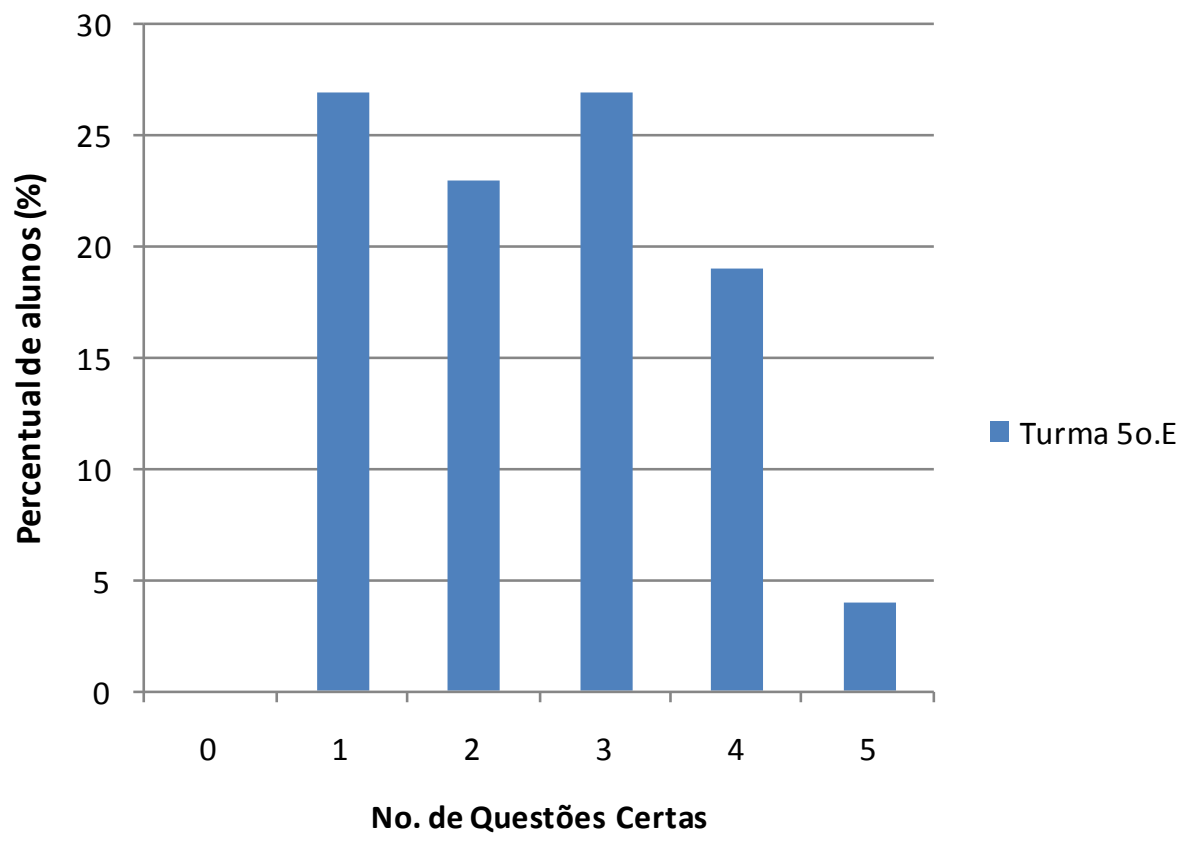

Fonte: a autora, 2012 
Gráfico 15

PERCENTUAL DOS ALUNOS DA TURMA DO 5 ANO E, SEGUNDO O NÚMERO DE QUESTÕES CERTAS. PRANCHA TEMÁTICA SOROCABA: ÁREA URBANA E ÁREA RURAL - 2012

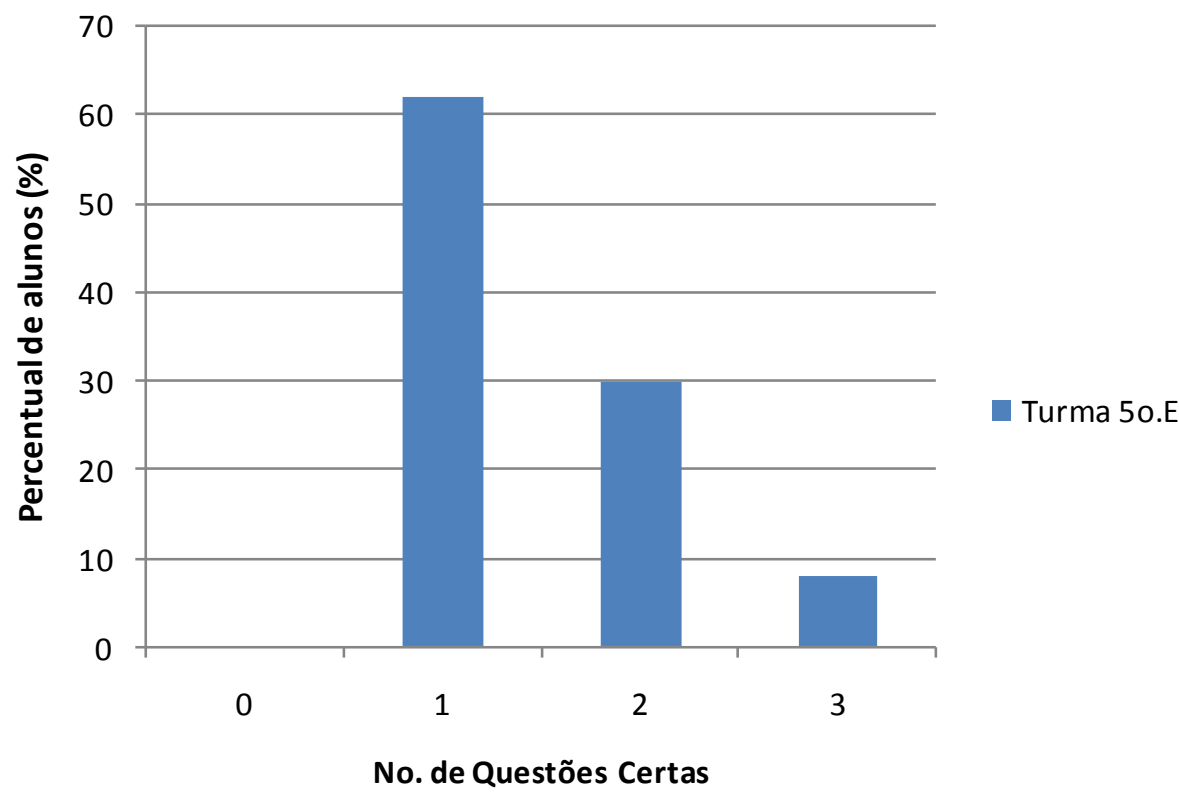

Fonte: a autora, 2012 
Modelo da Proposta metodológica para avaliação parcial do CAPÍTULO V SOROCABA: GEOGRAFIA. PRANCHA TEMÁTICA - SOROCABA: POPULAÇÃO - 5o Ano, turma $E$

Proposta metodológica para avaliação parcial do CAPÍTULO V - Sorocaba: GEOGRAFIA. Prancha Temática - SOROCABA: POPULAÇÃO. 5o ano E. Escola Estadual Baltazar Fernandes.

\begin{tabular}{|c|c|c|}
\hline ATIVIDADES & CONTEÚDOS & $\begin{array}{c}\text { O QUE SE ESPERA DO } \\
\text { ALUNO }\end{array}$ \\
\hline $\begin{array}{c}\text { ETAPA I } \\
\text {. Avaliação do } \\
\text { mapa }\end{array}$ & $\begin{array}{c}\text {.Classificação da } \\
\text { população em urbana e } \\
\text { rural } \\
\text {.Divisão do município em } \\
\text { zonas urbanas } \\
\text {. Análise das legendas: } \\
\text { - População Total } \\
\text { - População Urbana e } \\
\text { Rural }\end{array}$ & $\begin{array}{c}\text { Que o aluno faça a leitura } \\
\text { do mapa e que a partir } \\
\text { dela perceba: } \\
\text { - A distribuição da } \\
\text { população no município, } \\
\text { segundo as suas zonas. } \\
\text { - Qual é a zona mais } \\
\text { populosa. } \\
\text {-Em que zona a população } \\
\text { rural é maior que a } \\
\text { urbana. } \\
\text { - Em qual zona não há } \\
\text { mais população rural } \\
\text {-E por fim, quais as duas } \\
\text { zonas em que a } \\
\text { população rural está mais } \\
\text { presente em relação a } \\
\text { total, frente às demais } \\
\text { zonas. }\end{array}$ \\
\hline
\end{tabular}

Quadro 37 - Proposta metodológica para avaliação parcial do Capítulo 5 - Sorocaba: Geografia. Prancha Temática - Sorocaba: População. 5oano. Fonte: a autora, 2012. 
Apresentação das atividades executadas pelos alunos do 5 o anos

\section{PRANCHA TEMÁTICA: POPULAÇÃO}

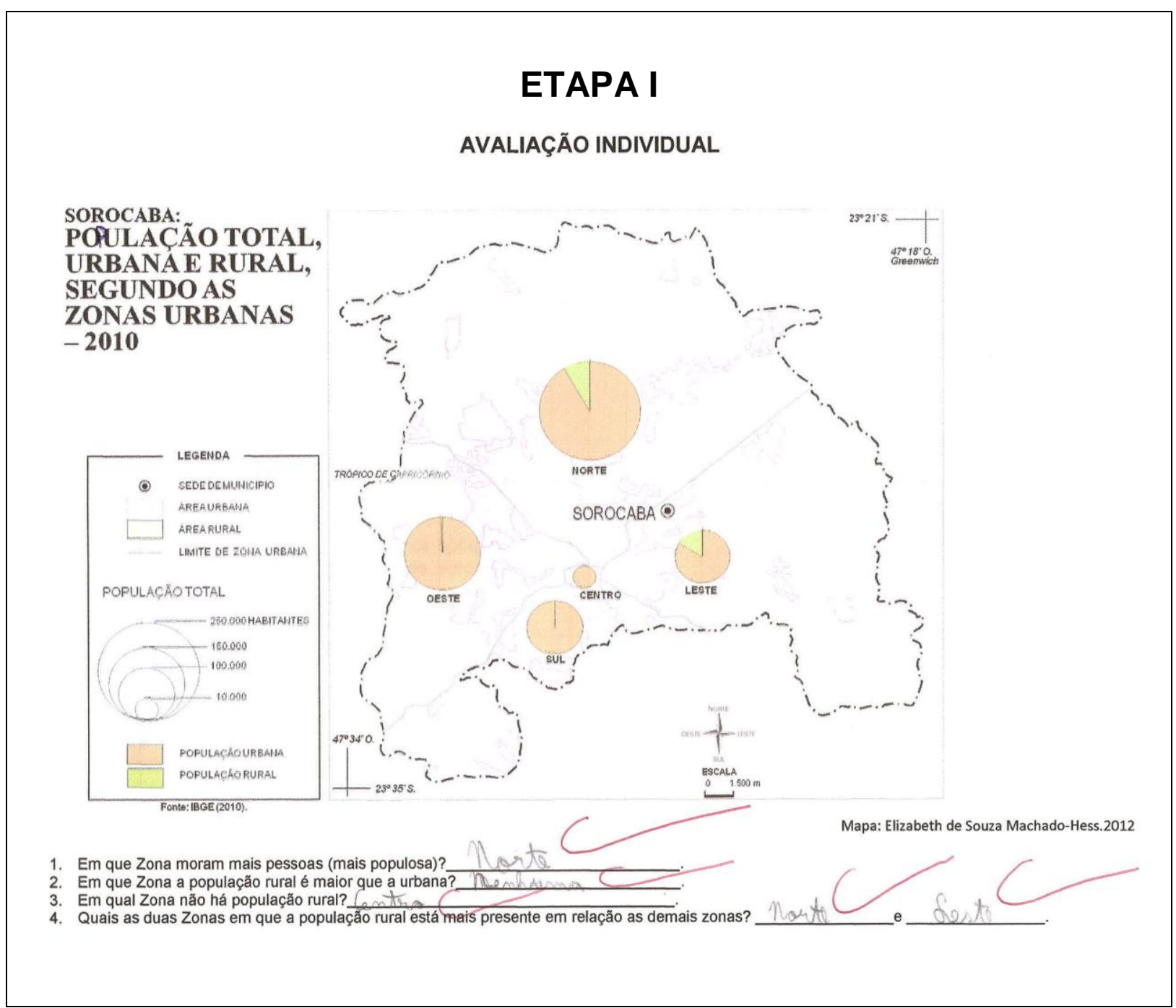

Quadro 38 - Exemplo da Avaliação realizada. Capítulo 5 - Sorocaba: Geografia. Prancha Temática Sorocaba: População. $5^{\circ}$ ano, turma "E”. Fonte: a autora, 2012. 
Análise dos Resultados da Avaliação da Prancha Temática - Sorocaba:

\section{População - 5o, turma E}

O gráfico 16 corresponde à avaliação da prancha temática "População Total: urbana e rural", representando o desempenho dos alunos da turma do 5o. ano E, em relação à sua capacidade de interpretação do mapa associado ao tema. No eixo das ordenadas, encontra-se o percentual dos alunos, enquanto que no eixo das abscissas, apresenta-se o número de questões certas. Participaram da avaliação 26 alunos desta turma.

Da análise do gráfico 16, nota-se que os alunos obtiveram um bom desempenho. O mesmo gráfico indica que apenas $23 \%$ dos alunos acertaram menos da metade das questões propostas.

Gráfico 16
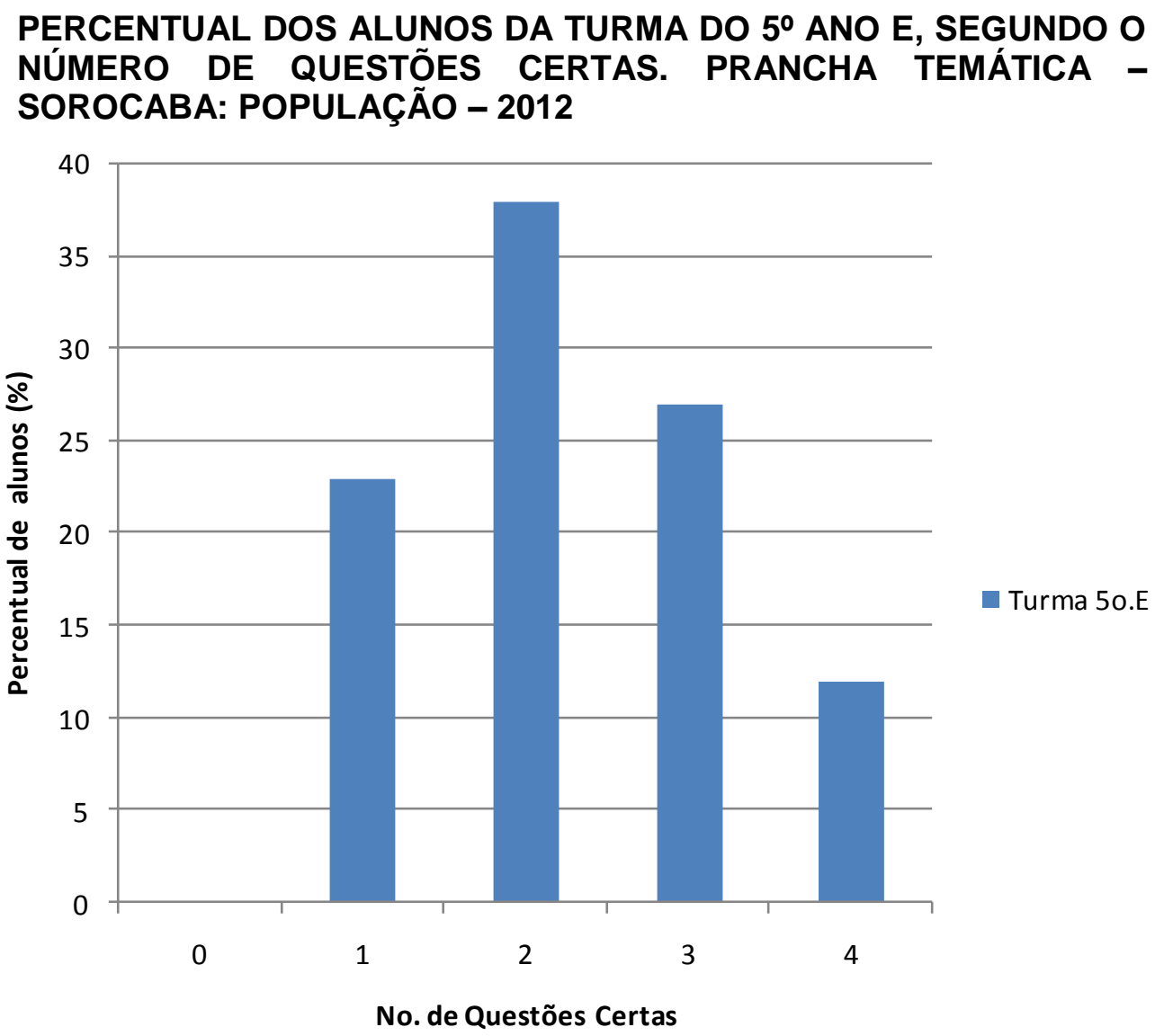

Fonte: a autora, 2012. 
Modelo da proposta metodológica para avaliação parcial do CAPÍTULO 5 SOROCABA: GEOGRAFIA. PRANCHA TEMÁTICA: USO DA TERRA E COBERTURA DO SOLO - 5 ano, turma "E"

\begin{abstract}
Proposta metodológica para avaliação parcial do Capítulo 5 - Sorocaba: Geografia. Prancha Temática: USO DA TERRA E COBERTURA DO SOLO. 5o Ano, turma "E”. Escola Estadual Baltazar Fernandes.
\end{abstract}

\begin{tabular}{|c|c|c|}
\hline ATIVIDADES & CONTEÚDOS & $\begin{array}{c}\text { O QUE SE ESPERA DO } \\
\text { ALUNO }\end{array}$ \\
\hline $\begin{array}{c}\text { ETAPA I } \\
\text { Relacionar a primeira } \\
\text { coluna (definição de } \\
\text { diferentes usos da terra e } \\
\text { cobertura do solo) com a } \\
\text { segunda (fotos das } \\
\text { paisagens representativas } \\
\text { de diferentes usos da } \\
\text { terra e cobertura do solo) }\end{array}$ & $\begin{array}{l}\text { - Solo exposto } \\
\text { - Reflorestamento } \\
\text {-Área industrial } \\
\text {-Mata ciliar } \\
\text {-Agricultura } \\
\text {-Mineração } \\
\text {-Floresta } \\
\text {-Cerrado }\end{array}$ & $\begin{array}{c}\text { Que o aluno consiga } \\
\text { relacionar a partir dos } \\
\text { seus conhecimentos } \\
\text { prévios e análise das } \\
\text { figuras das paisagens, } \\
\text { os conceitos às imagens } \\
\text { da paisagem } \\
\text { correspondente }\end{array}$ \\
\hline $\begin{array}{c}\text { ETAPA II } \\
\text { Fazer a leitura do texto e } \\
\text { responder às questões } \\
\text { dadas }\end{array}$ & $\begin{array}{l}\text { - Definição para Uso da terra } \\
\text { e cobertura do solo } \\
\text { - O que é vegetação original } \\
\text { e secundária } \\
\text { - Vegetação arbustiva e } \\
\text { herbácea } \\
\text { - O que são áreas } \\
\text { degradadas } \\
\text { - Preservação ambiental }\end{array}$ & $\begin{array}{l}\text { Que o aluno com base } \\
\text { no texto, na aula } \\
\text { expositiva e no debate, } \\
\text { não tenha grandes } \\
\text { dificuldades para } \\
\text { responder as questões } \\
\text { apresentadas }\end{array}$ \\
\hline $\begin{array}{c}\text { ETAPA III } \\
\text {. Avaliação do mapa } \\
\text { A avaliação do mapa foi } \\
\text { feita por meio da } \\
\text { aplicação de um } \\
\text { questionário com oito } \\
\text { perguntas. }\end{array}$ & $\begin{array}{c}\text {.Iniciação Cartográfica: } \\
\text { Os elementos do mapa: } \\
\text { Título, } \\
\text { Legenda, } \\
\text { Orientação } \\
\text { Escala } \\
\text { Fonte }\end{array}$ & $\begin{array}{c}\text { Espera-se que o aluno } \\
\text { consiga mediante a } \\
\text { leitura do mapa } \\
\text { fornecido (Sorocaba: } \\
\text { Uso da terra e cobertura } \\
\text { do solo), responder a } \\
\text { questões, como por } \\
\text { exemplo: Onde há mais } \\
\text { áreas exploradas com o } \\
\text { reflorestamento? Onde } \\
\text { estão as áreas } \\
\text { industriais? Qual o tipo } \\
\text { de uso da terra e } \\
\text { cobertura do solo que } \\
\text { predomina no município } \\
\text { e onde se encontra? } \\
\text { Onde não tendo } \\
\text { cobertura, o solo se } \\
\text { apresenta mais exposto? }\end{array}$ \\
\hline
\end{tabular}

Quadro 39 - Proposta metodológica para avaliação parcial do Capítulo 5 - Sorocaba: Geografia Prancha Temática: Uso da terra e cobertura do solo. 5ํAno, turma "E". Fonte: a autora, 2012. 
PRANCHA TEMÁTICA: USO DA TERRA E COBERTURA DO SOLO

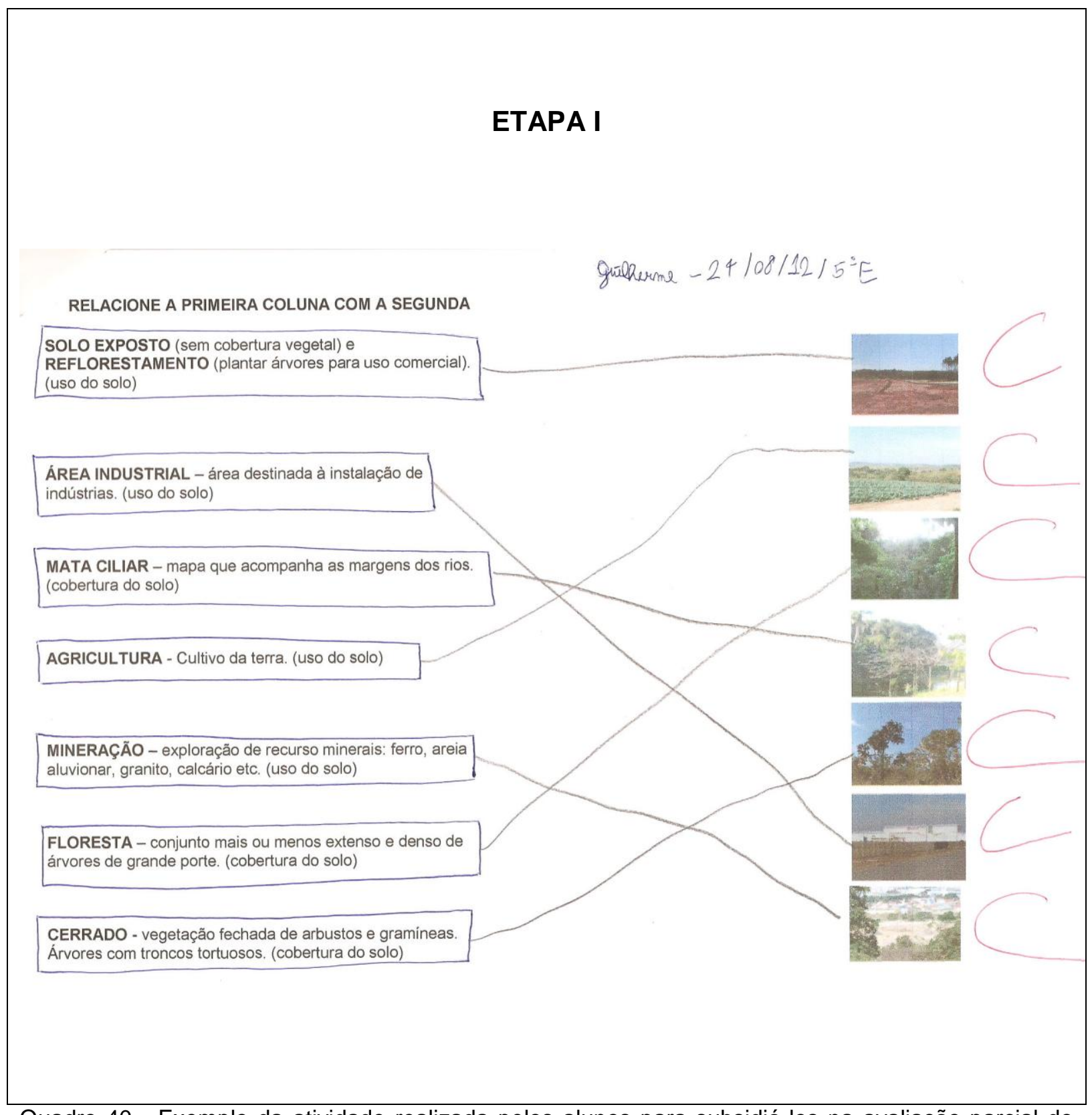

Quadro 40 - Exemplo da atividade realizada pelos alunos para subsidiá-los na avaliação parcial do Capítulo 5 - Sorocaba: Geografia. Prancha Temática - Sorocaba: uso da terra e cobertura do solo. 5은 ano, turma "E". Etapa I. Fonte: a autora, 2012. 


\section{ETAPA II}

\section{SOROCABA: \\ USO DA TERRA E COBERTURA DO SOLO}

Uso da terra se refere às atividades da sociedade relacionadas com a terra, como a agricultura e a pecuária. $A$ cobertura do solo descreve as diversas formações vegetais (florestas, cerrados etc) e construções artificiais como: instalações de galpões, construções, moradias etc.

No municipio de Sorocaba, completam o verde da área rural as áreas de reflorestamento, sendo uma localizada no extremo norte e outras nas partes limítrofes do sudoeste e oeste do município.

Hoje o que se vê percorrendo o território de Sorocaba são pequenas áreas de vegetação secundária. Da cobertura vegetal original pouco ou nada resta. Há um pouco de floresta secundária no extremo leste, na divisa com Itu, Mairinque e Alumínio e mais um pouco na porção do extremo sudeste na divisa com Votorantim. Porém, não é uma floresta primitiva e sim uma mata secundária.

Embora na paisagem sorocabana se mostre verde, os campos são vegetação arbustiva ou herbácea resultante da diminuição de atividades humanas, como o abandono de culturas ou pastagens, ou mesmo instalações de sítios e chácaras que muitas vezes são alugadas para temporada.

A cobertura do solo ainda se completa com a área urbanizada que corresponde à cidade e ocupa uma boa porção do município em sua parte centro-oeste.

$$
\begin{aligned}
& \text { Guilherme - } 24 / 0 \gamma / 12-5^{2} E \\
& \text { goilher }
\end{aligned}
$$

Responda as questões com base no texto

1. O que significa Uso da terra?

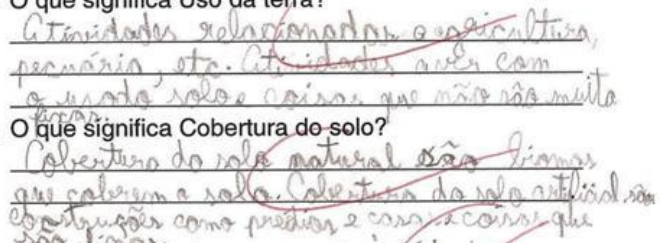

A área urbaniżada corresponde: (à cidade ou ao campo)

4. Que atividades humanas podem provocar degradação ambiental?

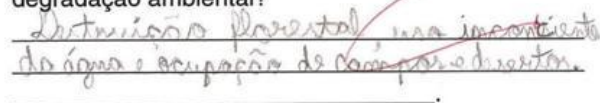

5. O que é preciso fazer para que as áreas degradadas do meio ambiente voltem a se recompor?

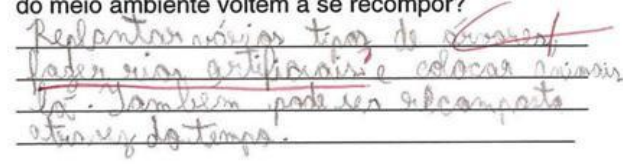

Quadro 41 - Exemplo da atividade realizada pelos alunos para subsidiá-los na avaliação parcial do Capítulo 5 - Sorocaba: Geografia. Prancha Temática - Sorocaba: uso da terra e cobertura do solo. 5o ano, turma "E". Etapa II. Fonte: a autora, 2012. 


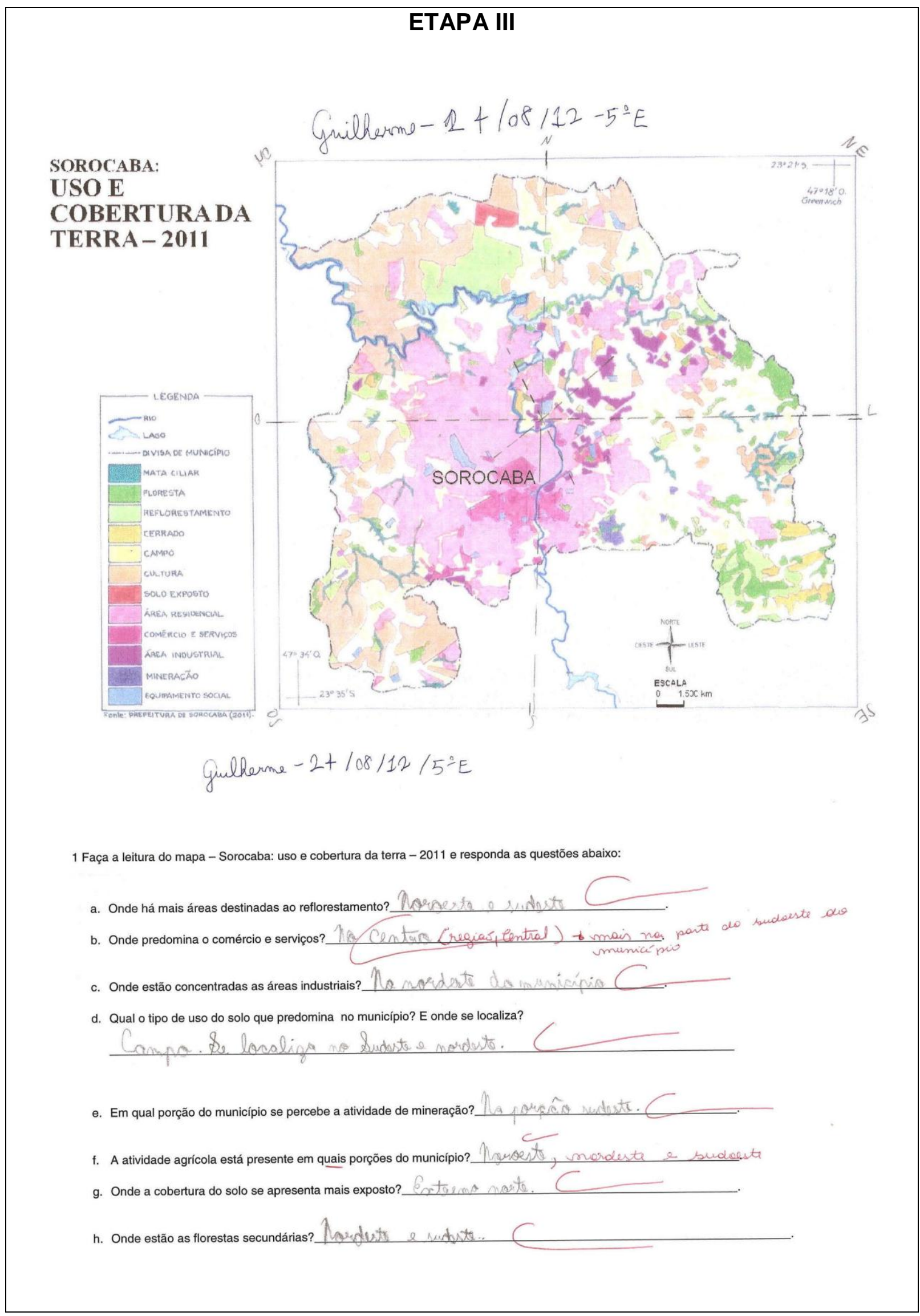

Quadro 42 - Exemplo da Avaliação realizada. Capítulo 5 - Sorocaba: Geografia. Prancha Temática Sorocaba: uso da terra e cobertura do solo. $5^{\circ}$ ano, turma "E". Fonte: a autora, 2012. 


\section{Análise dos resultados da Avaliação da Prancha Temática - Sorocaba: Uso da} terra e cobertura do solo - 5을 $\mathrm{E}$

Os gráficos 19 e 20 correspondem à avaliação da prancha temática "Uso e cobertura da terra", representando o desempenho dos alunos da turma do 5o. ano E, em relação à sua capacidade de interpretação do texto e do mapa associado ao tema. No eixo das ordenadas, encontra-se o percentual dos alunos, enquanto que no eixo das abscissas, apresenta-se o número de questões certas. Participaram da avaliação 28 alunos desta turma.

Da análise dos gráficos 19 e 20, percebe-se que os alunos obtiveram um bom desempenho. De fato, o gráfico 19 indica que apenas $14 \%$ dos alunos acertaram menos da metade das questões propostas, enquanto que pelo gráfico 20 , observase que $32 \%$ acertaram menos da metade das questões propostas.

\section{Gráfico 17}
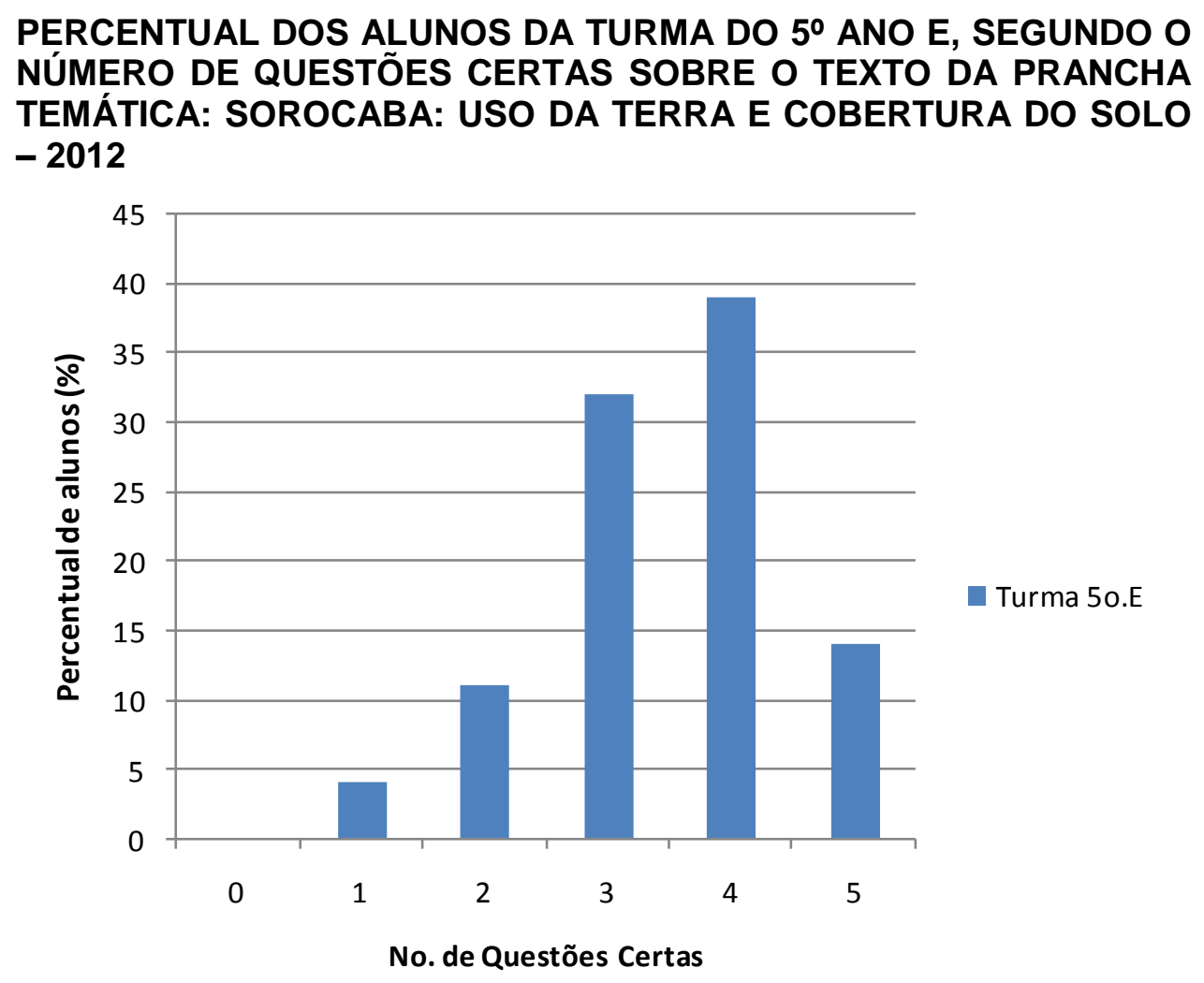
Gráfico 18

PERCENTUAL DOS ALUNOS DA TURMA DO 50 ANO E, SEGUNDO O NÚMERO DE QUESTÕES CERTAS. PRANCHA TEMÁTICA SOROCABA: USO DA TERRA E COBERTURA DO SOLO - 2012

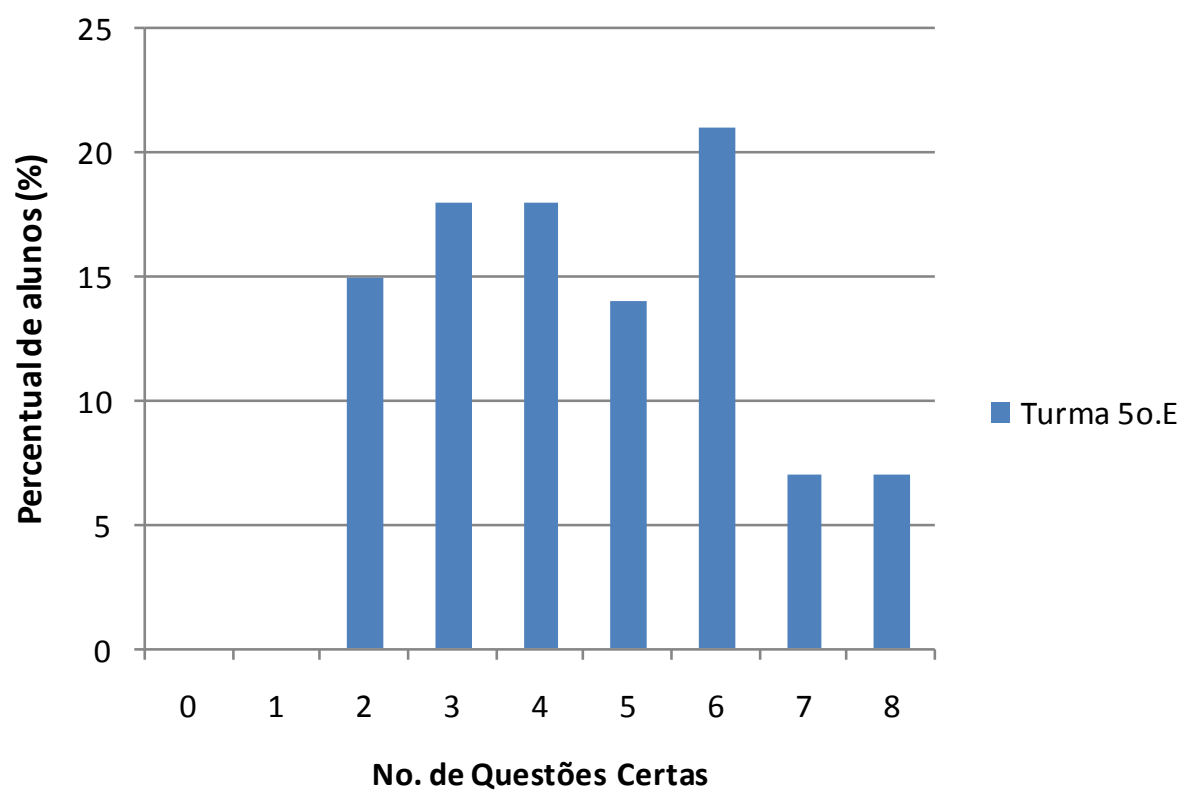

Fonte: a autora, 2012. 


\subsubsection{As avaliações na Escola Estadual Brigadeiro Tobias}

\subsubsection{Capítulo 3 - Sorocaba: sua história}

O capítulo 3 - Sorocaba: sua história compõe-se das seguintes pranchas temáticas:

. Linha do Tempo

. Civilização Pré-Histórica

. Presença do homem branco

. Bandeirismo

. Do povoado ao município

. Tropeirismo

. Liberalismo

. A Ferrovia

- Industrialização

- Terceirização

. Centro Tecnológico

A avaliação das Pranchas Temáticas deste capítulo contou com a colaboração de três profissionais da área acadêmica. Primeiramente foi avaliado pelo notório professor, historiador e presidente do IHGG (Instituto Histórico Geográfico e Genealógico de Sorocaba-SP) Adilson Cezar. Depois foi a vez da professora historiadora Raquel Brito que leciona há 15 anos na rede municipal para o Ensino Fundamental I e II que contribuiu com as correções dos textos e sugestões de atividades e por fim, pela professora Maria Cristina, licenciada em Pedagogia e Arte-Educadora que aplicou o conteúdo e atividades para avaliar a Prancha Temática do protótipo - Linha do Tempo, em três turmas de $5^{\circ}$ anos (A, B e C), na Escola Estadual Brigadeiro Tobias, em Sorocaba-SP.

Assim, o capítulo III - Sorocaba: sua história foi o único avaliado na Escola Estadual Brigadeiro Tobias. A colaboração e atuação da professora Maria Cristina na aplicação da prancha temática em questão, foi diferenciada em relação às 
professoras da Escola Estadual Brigadeiro Tobias. que se colocou na situação de professora usuária.

No dia 08 de agosto de 2012, foi entregue à professora Maria Cristina uma cópia do Capítulo em questão e um modelo de propostas de atividades para avaliação do capítulo III - Sorocaba: sua história para que ela o avaliasse. $\mathrm{Na}$ ocasião ficou decidido que ela se colocaria como usuária crítica do protótipo, para em seguida, trabalhá-lo com seus alunos.

As pranchas deste capítulo foram todas aplicadas pela professora sem intervenções da pesquisadora. No final, ela apresentou um relatório referente aos procedimentos didáticos empregados por ela na sala de aula, as atividades desenvolvidas pelos alunos e uma avaliação crítica dos textos, figuras e mapas que integram o capítulo III do protótipo.

A seguir será apresentado o modelo de proposta metodológica para avaliação parcial do capítulo, propostas de atividades, alguns exemplos de atividades realizadas pelos alunos e, por fim, uma breve análise dos resultados mediante gráficos estatísticos. 


\section{ETAPA I}

Elabore uma linha do tempo de sua vida, desde o seu nascimento até os dias atuais. Destaque os fatos mais importantes de acordo com suas próprias lembranças. Peça ajuda aos pais. Você pode contar também com a ajuda de fotografias.

Quadro 44 - Proposta da atividade para avaliação parcial do Capítulo 3 - Sorocaba: sua história. Prancha temática: Linha do tempo - 5ำ ano. Fonte: a autora, 2012.

\section{ETAPA II}

\section{Avaliação da Prancha Temática: Linha do Tempo}

Observe a linha do tempo de Sorocaba. Pinte de amarelo o ano de fundação da cidade. De laranja os fatos que aconteceram fora do Brasil. Agora, de verde os fatos ocorridos no Brasil. Por último, de marrom os fatos ocorridos em Sorocaba-SP.
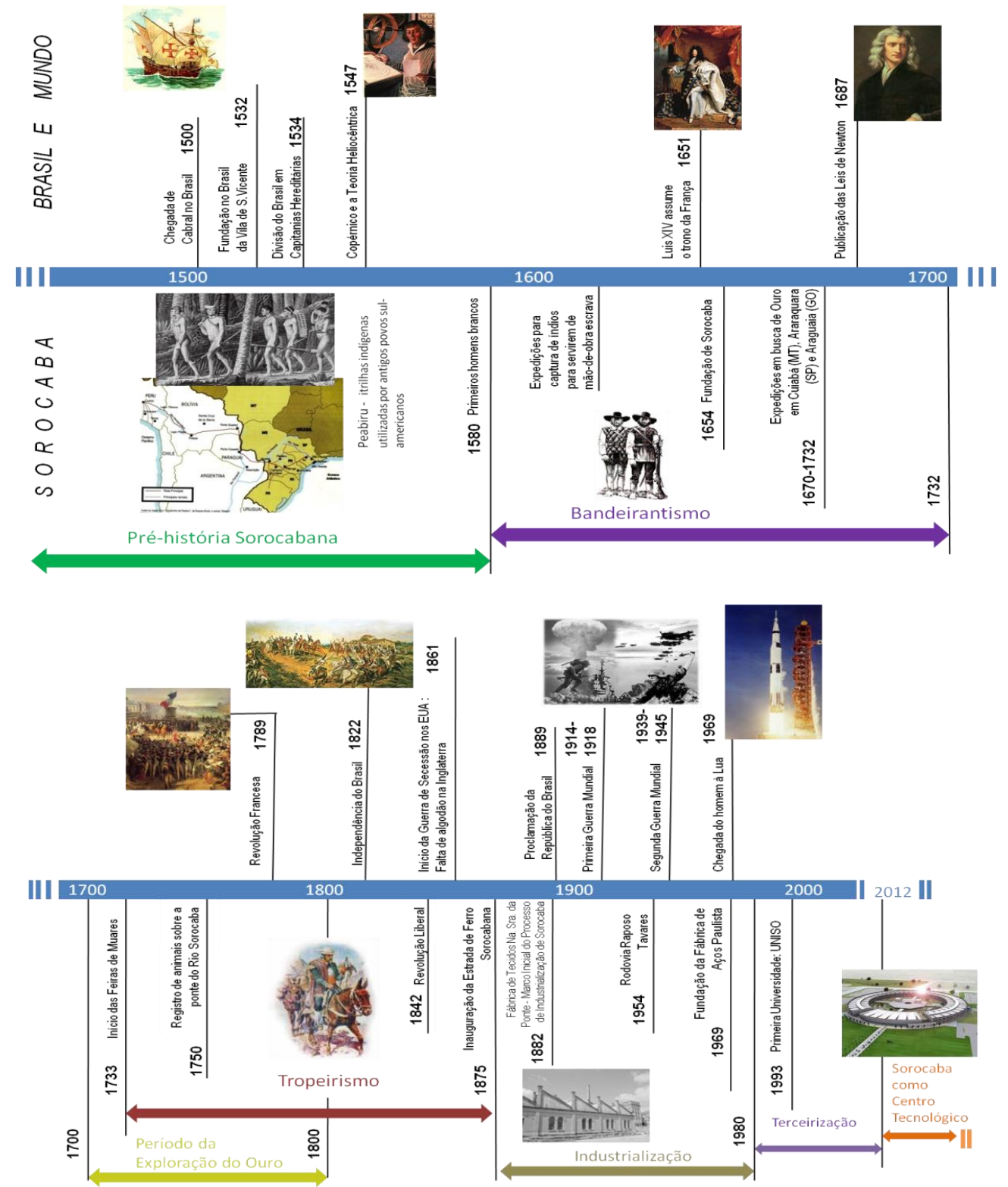

Quadro 45 - Proposta da atividade para avaliação parcial do Capítulo 3 - Sorocaba: sua história. Prancha temática: Linha do tempo - 5o ano. Fonte: a autora, 2012. 


\section{Apresentação das atividades executadas pelos alunos}

ETAPA I - Construção da Linha do Tempo do aluno

Nesta etapa, a professora Maria Cristina solicitou aos seus alunos a construção da uma linha do tempo de sua vida, desde o seu nascimento até os dias atuais, destacando os fatos mais importantes de acordo com suas próprias lembranças, através de documentos pessoais como certidão de nascimento, carteira de vacina, registro escolar etc.

Todos os fatos poderiam ser representados através de desenhos ou fotos. O trabalho começou na salda de aula, porém, os alunos deveriam terminá-lo em casa com a ajuda dos pais.

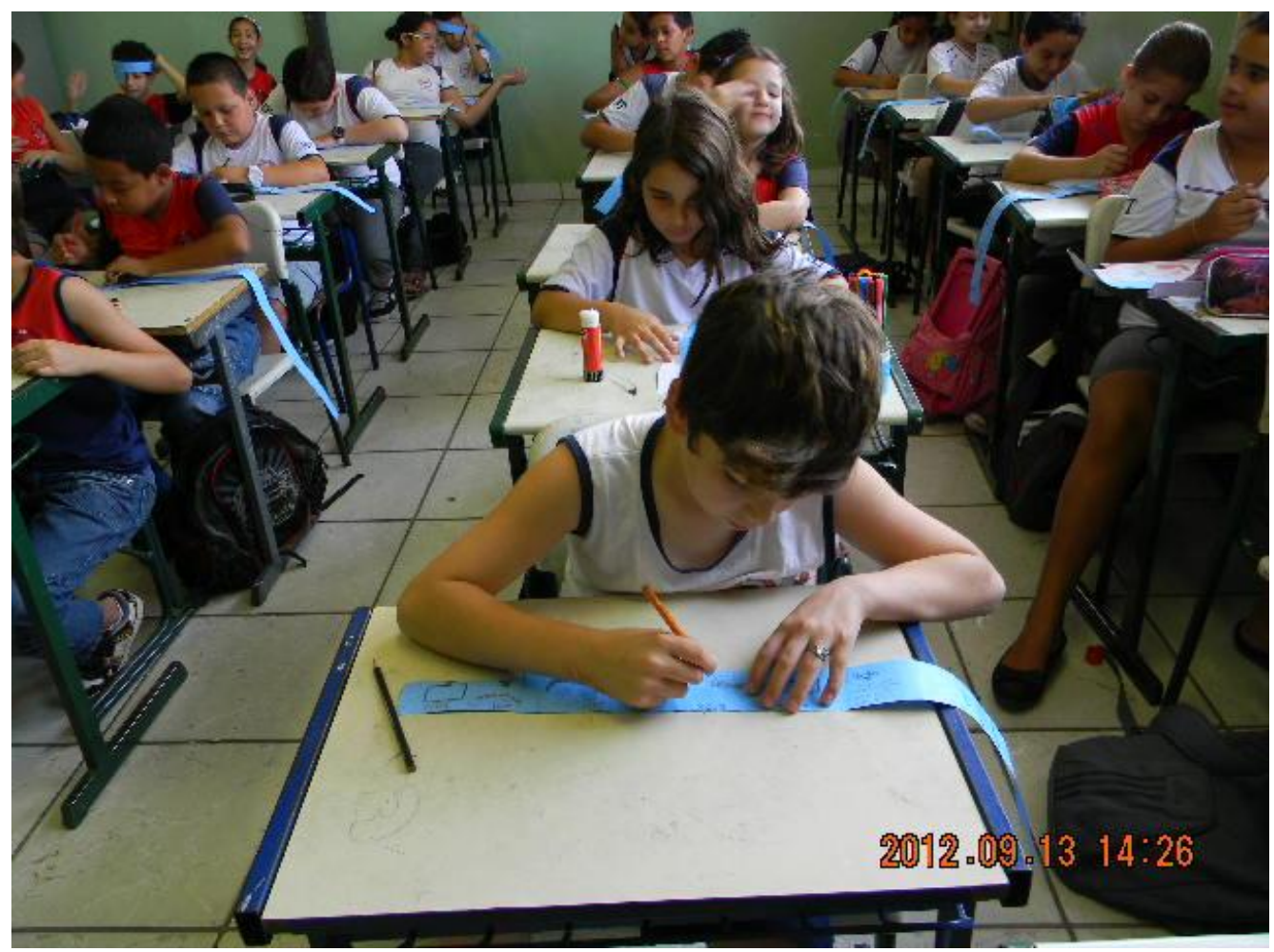

Figura 20 - Alunos do $5^{\circ}$ ano, turma "A" da Escola Estadual Brigadeiro Tobias confeccionando a sua Linha do Tempo. Fonte: Maria Cristina Lopes, 2012. 
Os alunos demonstraram muito interesse nesta atividade. Todos se empenharam na construção da sua Linha do Tempo, procurando relatar fatos marcantes da suas vidas. Fatos ora positivos, ora negativos. Todo esse material foi recolhido e analisado. Abaixo, segue um exemplo de uma Linha do Tempo de uma aluna do $5^{\circ} \mathrm{A}$.
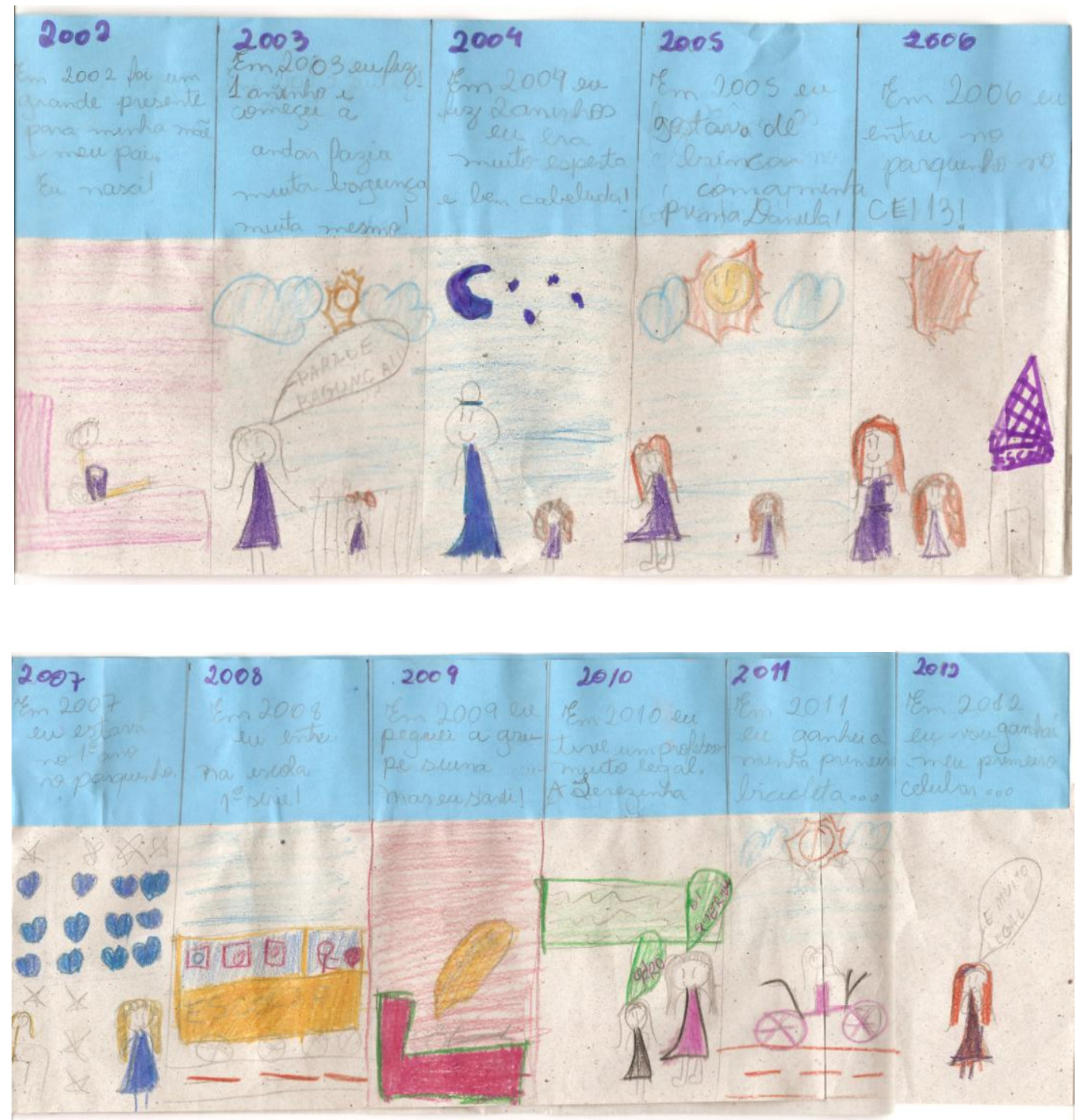

Figura 21 - Linha do Tempo construída por uma aluna do 5ำ ano, turma "A". Fonte: Maria Cristina Lopes, 2012. 
ETAPA II - Avaliação da Prancha Temática: Linha do Tempo.

Na Etapa II, a professora Maria Cristina antes de trabalhar a atividade envolvendo a Linha do Tempo de Sorocaba, teve o cuidado de preparar os alunos para tal tarefa. Assim, todos os textos que compõem o Capítulo III - Sorocaba: sua história foram trabalhados com os alunos mediante leituras, discussões seguidas de atividades envolvendo os textos, mapas e figuras.

Para ajudar no entendimento, foi passado para os alunos o filme "Os Caminhos de Sorocaba, dirigido e produzido pelo cineasta Vicenti Gomez, com o apoio das Secretarias da Educação e Cultura da Prefeitura de Sorocaba. Esse filme conta a história de Sorocaba, desde a sua fundação até os dias atuais, servindo-se de uma linguagem próxima do escolar do ensino fundamental, em quarenta e cinco minutos.

Foi feita também uma visita sob a supervisão da professora no Museu Histórico Sorocabano, situado dentro do Zoológico Municipal Quinzinho de Barros. $\mathrm{Na}$ oportunidade, os alunos puderam apreciar pessoalmente, o que já tinham visualizado através de fotos do capítulo III em questão, como artefatos de sítios arqueológicos líticos, como machados do período Neolítico e pontas de flechas do período Paleolítico. Bem como artefatos produzidos com barro, como as igaçabas ou urnas funerárias encontradas em Capela do Alto, Sorocaba e Araçoiaba da Serra. Os alunos estavam cada vez mais motivados para conhecer e entender um pouco mais sobre a história da cidade na qual eles residem.

Dada a formação da professora Maria Cristina em "Pedagogia e ArteEducadora, a professora selecionou fotos históricas relacionadas aos temas abordados nos textos do capítulo III, como a foto da antiga estação ferroviária sorocabana, do Mosteiro São Bento dentre outras. O objetivo era que os alunos observassem tais fotos e a partir delas, buscassem uma relação entre o "antes e o depois", isto é, o objetivo era que os alunos relacionassem as diferenças entre a arquitetura de antes e a atual, bem como qual era a função dessa arquitetura no passado, e qual a sua função hoje? 


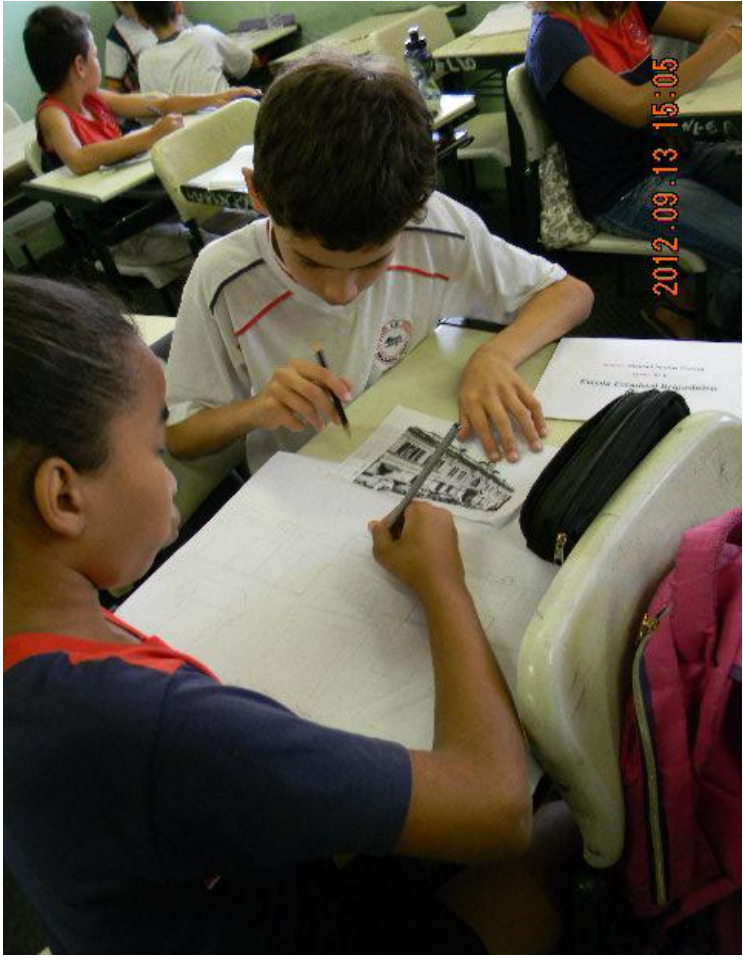

(a)

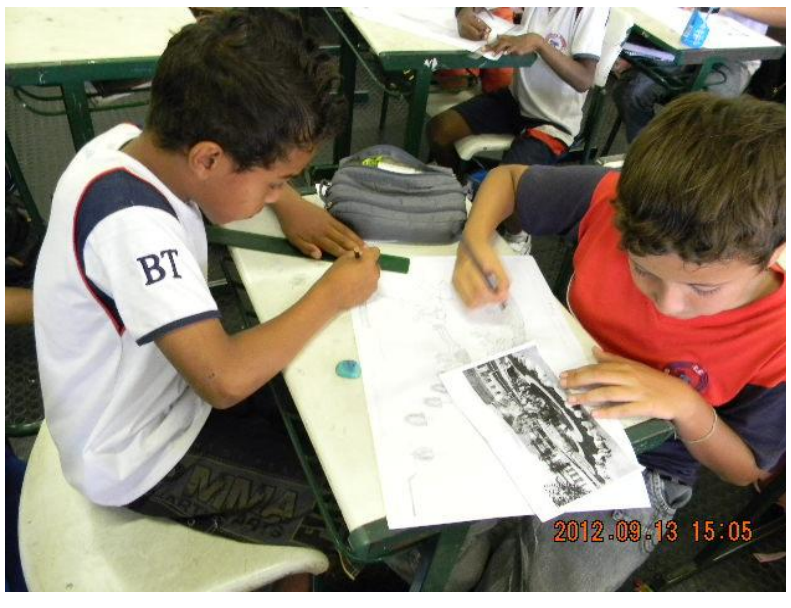

(c)

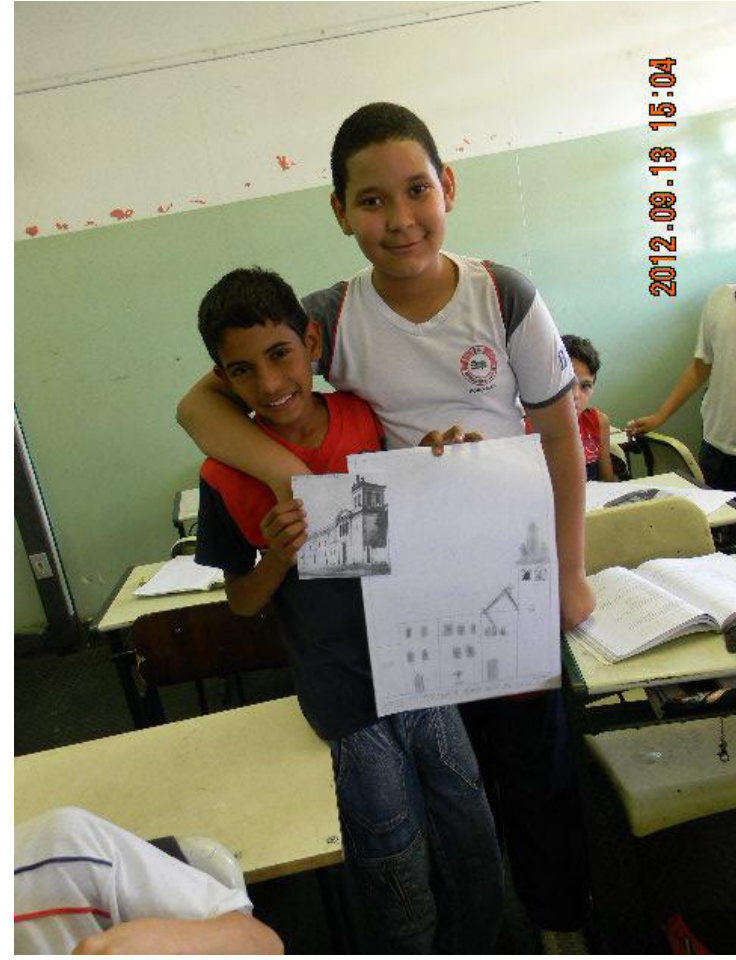

(b)

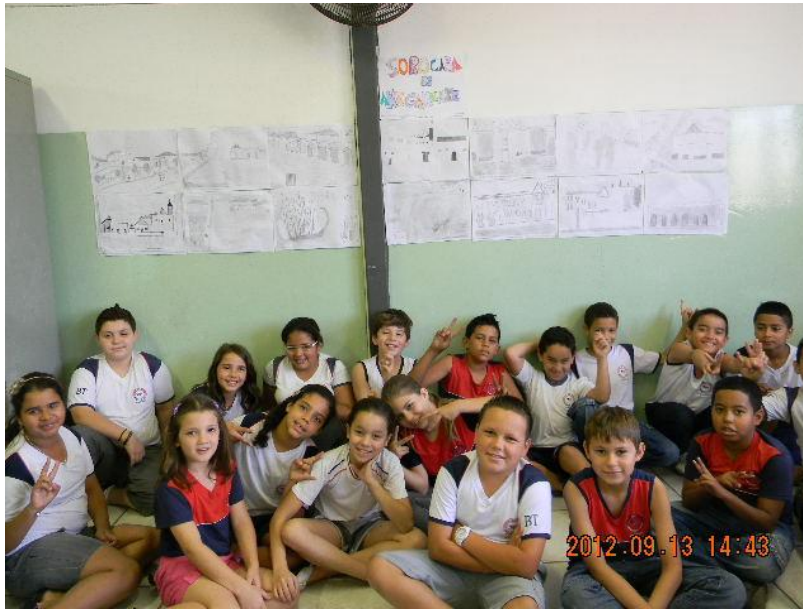

(d)

Figura 22 - Alunos do $5^{\circ}$ ano, turma A, reproduzindo uma paisagem do centro histórico da cidade de Sorocaba-SP, através de um desenho a mão livre, sob orientação da professora Maria Cristina, (a), (b) e (c). Fonte: Maria Cristina Lopes, 2012.

Após todos os procedimentos citados acima, a professora sentiu que os alunos estavam preparados para a Avaliação da Prancha Temática do Capítulo III Sorocaba: Linha do Tempo. Assim, foi solicitado que os alunos formassem duplas para a realização de tal atividade. Após a organização da sala de aula, a professora tomou como exemplo uma Linha do Tempo de um dos alunos e comparou com a 
Linha do Tempo do município de Sorocaba. A intenção da professora com essa ação era que os alunos percebessem a partir de sua própria realidade, ampliando sua visão,o que significa uma linha do tempo de um município que também está apoiada em documentos históricos, fotos antigas, depoimentos, registros em cartórios etc.

Para tanto, foi solicitado aos alunos que observassem a linha do tempo de Sorocaba. Depois, para que pintassem de amarelo o ano de fundação da cidade. De laranja os fatos que aconteceram fora do Brasil. E, em seguida, de verde os fatos ocorridos no Brasil. Por último, de marrom os fatos que se deram em Sorocaba-SP.

A proposta dessa atividade era que o aluno conseguisse destacar as diferenças e correlações entre a história local, nacional e a geral, retomando fatos que tiveram relação com a história de seu município, bem como outros nacionais e internacionais que, também, influenciaram a história de Sorocaba. Buscando entender que há relações entre os territórios, seja no campo político, econômico, social ou cultural, pois o que acontece em um lugar tem relação direta com outro, influenciando ou trazendo mudanças ou ainda consequências.

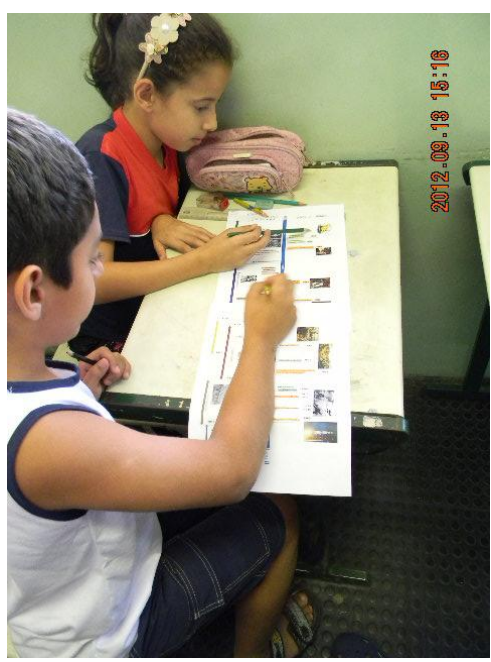

(a)

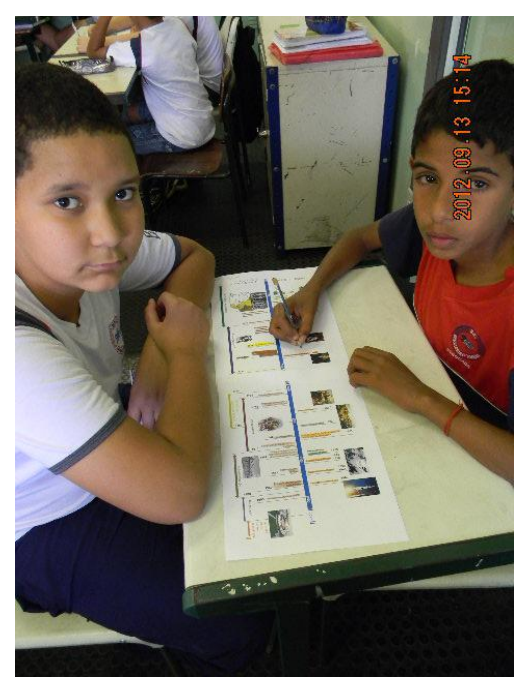

(b)

Figura 23. Avaliação em dupla da prancha temática: Linha do Tempo. Alunos do $5^{\circ}$ ano, turma A. (a) e (b). Fonte: Maria Cristina Lopes, 2012.

A seguir, segue um exemplo da atividade realizada por um aluno do $5^{\circ} \mathrm{C}$. A, que está de acordo com o que foi solicitado. 


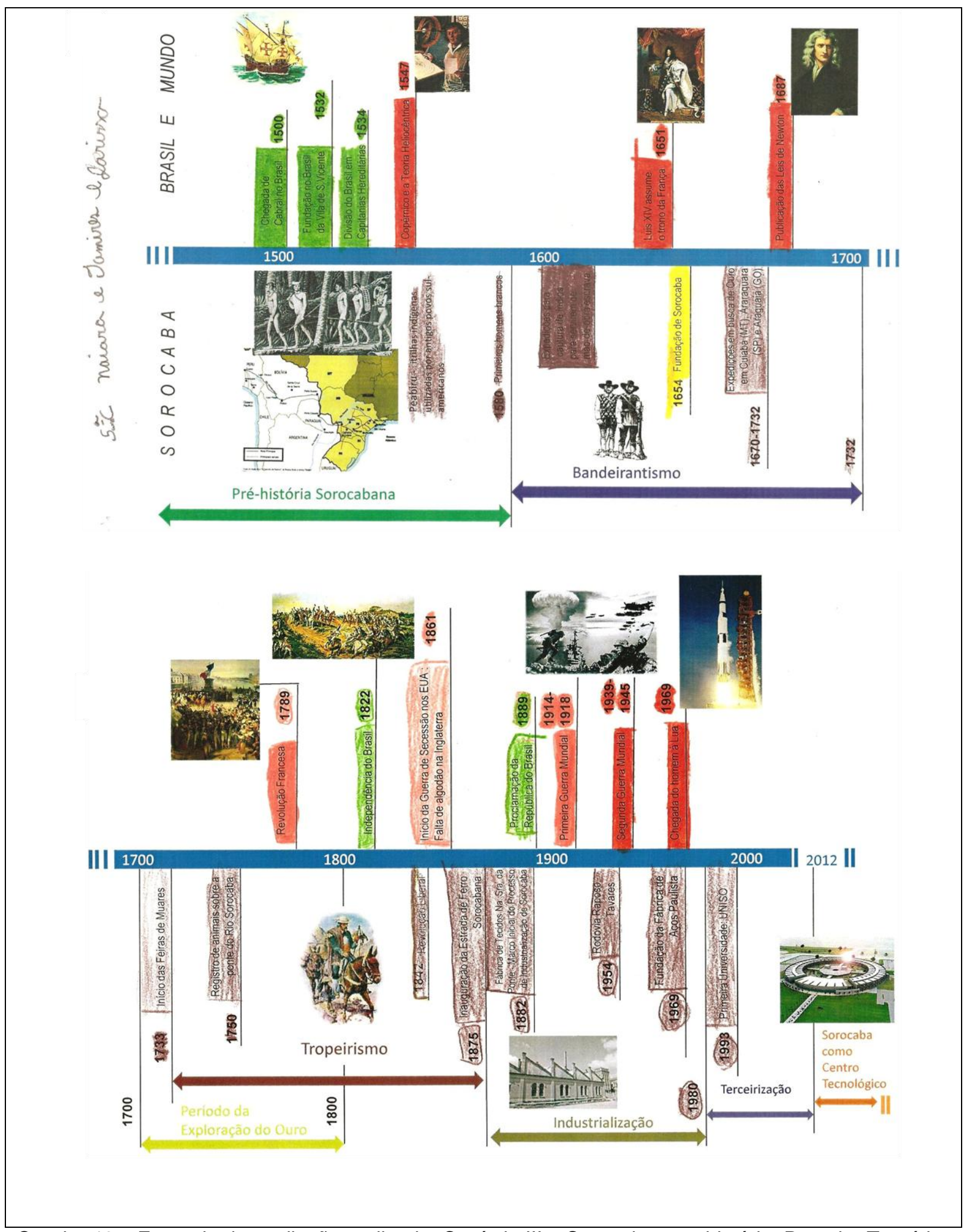

Quadro 46 - Exemplo da avaliação realizada. Capítulo III - Sorocaba: sua história. Prancha Temática: Linha do Tempo, $5^{\circ}$ ano, turma "C". Fonte: a autora, 2012. 


\section{Análise dos Resultados da Avaliação da Prancha Temática - SOROCABA: LINHA DO TEMPO - 50 anos, turmas A, B e C}

Os gráficos 19, 20 e 21 correspondem à avaliação da prancha temática "Linha do Tempo", representando o desempenho dos alunos das turmas dos 50 . anos A, B e $\mathrm{C}$, em relação à sua capacidade de identificação dos períodos ou eventos históricos sorocabanos, brasileiros e mundiais. No eixo das ordenadas, encontra-se o percentual da razão entre o número de acertos e o total de questões, enquanto que no eixo das abscissas, apresenta-se o período ou evento histórico. As turmas A, B e C possuíam 30, 36 e 30 alunos, respectivamente.

\section{Gráfico 19}

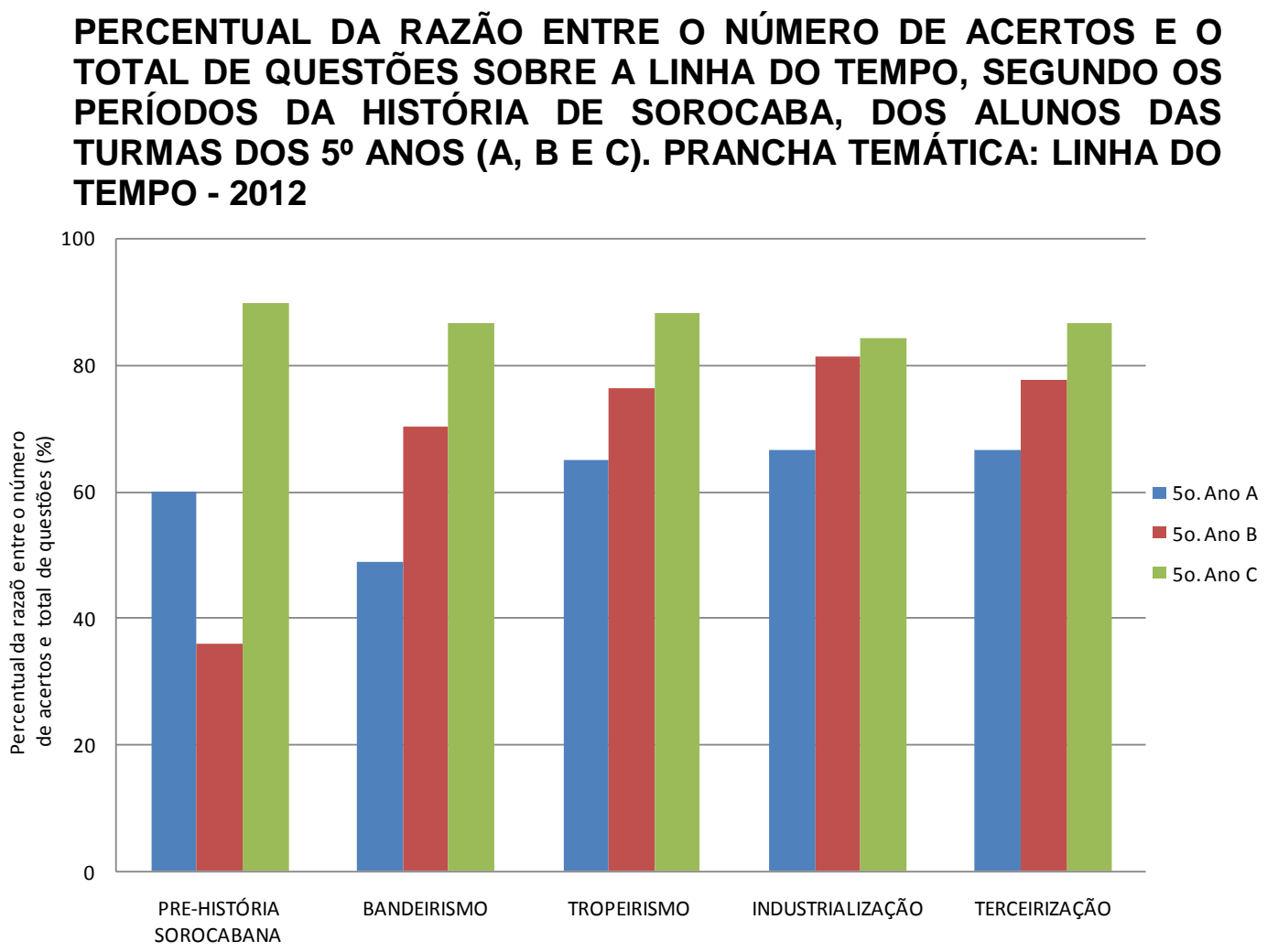

Fonte: a autora, 2012.

Da análise do gráfico 19, nota-se que os alunos acertaram, em média, mais da metade das questões propostas. Para alguns eventos, como as trilhas do Peabiru (período da pré-história sorocabana) ou as expedições que partiram de Sorocaba em busca de ouro em outras regiões do Brasil (Bandeirismo), os alunos não responderam por terem dúvidas em associá-los a Sorocaba ou ao Brasil. 
Gráfico 20

PERCENTUAL DA RAZÃO ENTRE O NÚMERO DE ACERTOS E O TOTAL DE QUESTÕES SOBRE A LINHA DO TEMPO, SEGUNDO OS EVENTOS HISTÓRICOS BRASILEIROS, DOS ALUNOS DAS TURMAS DOS 5 ANOS (A, B E C). PRANCHA TEMÁTICA: LINHA DO TEMPO 2012

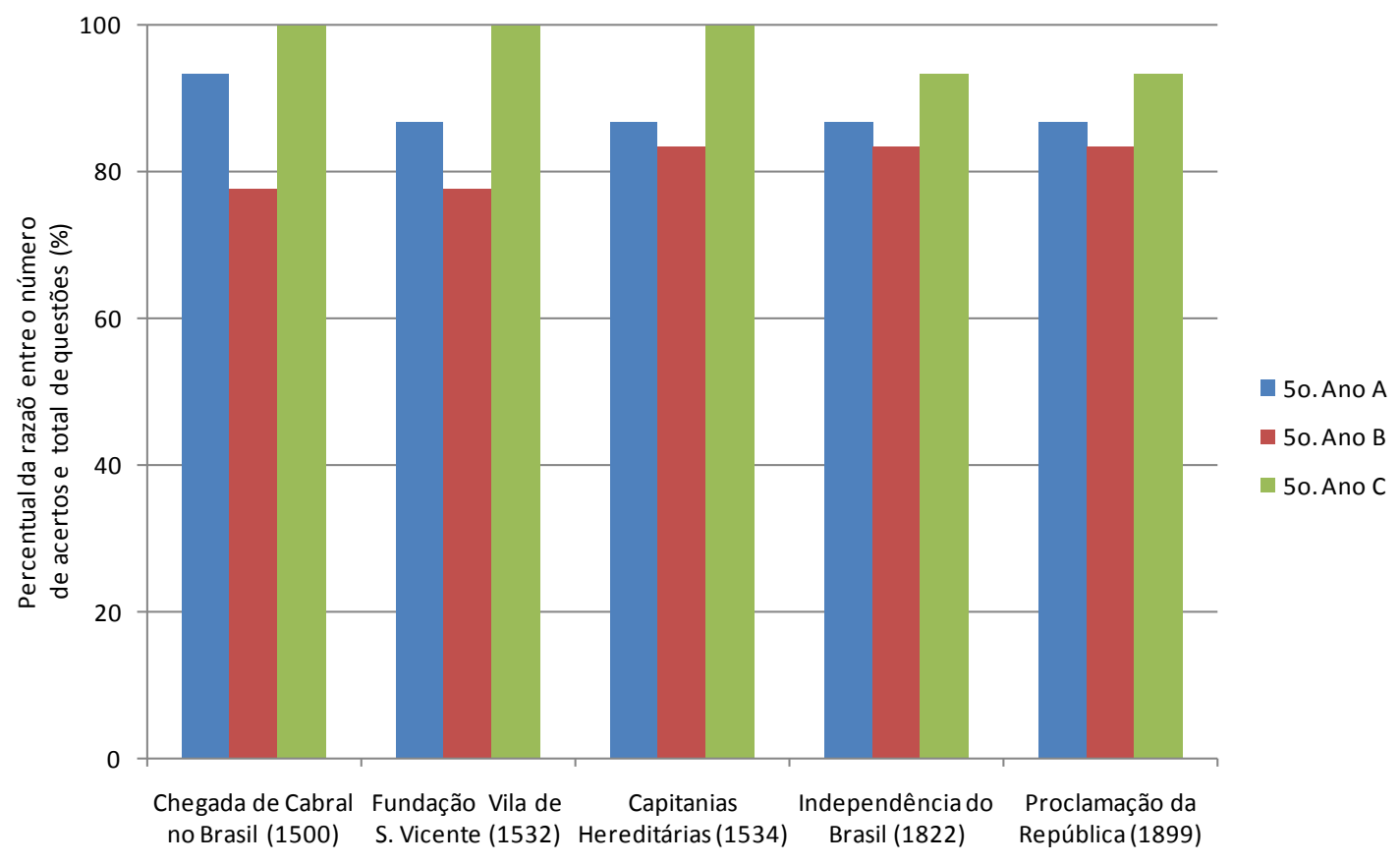

Fonte: a autora, 2012.

A partir do gráfico 20, percebe-se que os alunos demonstraram o melhor desempenho em identificar os eventos ou períodos históricos brasileiros. De fato, o percentual de acertos ficou entre 75 e $100 \%$. 
Gráfico 21

PERCENTUAL DA RAZÃO ENTRE O NÚMERO DE ACERTOS E O TOTAL DE QUESTÕES SOBRE A LINHA DO TEMPO, SEGUNDO OS EVENTOS HISTÓRICOS MUNDIAIS, DOS ALUNOS DAS TURMAS DOS 5 ANOS (A, B E C). PRANCHA TEMÁTICA: LINHA DO TEMPO 2012

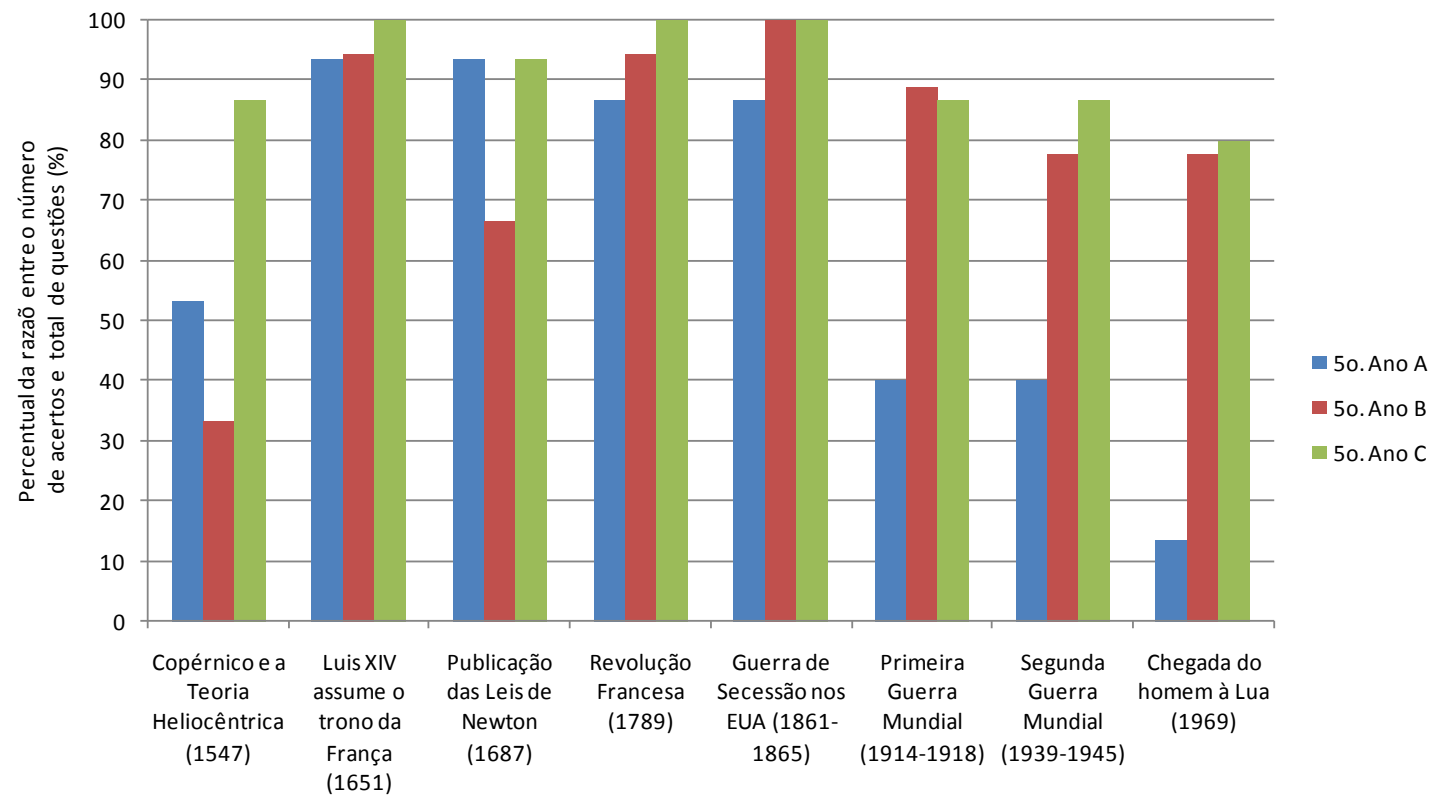

Fonte: a autora, 2012.

Por outro lado, observando-se o gráfico 21, nota-se que os alunos conseguiram identificar os eventos históricos mundiais quando o país associado ao evento estava explicitado, como por exemplo, a Revolução Francesa ou a Guerra de Secessão nos Estados Unidos. Caso contrário, surgiram dúvidas. 


\section{CONSIDERAÇÕES FINAIS}




\section{CONSIDERAÇÕES FINAIS}

Ao propor uma metodologia para a elaboração de Atlas Escolares para o conhecimento do Local esta Tese retoma a questão de se produzir recursos didáticos e sugerir práticas de ensino que sejam adequadas tanto para professor quanto para o aluno. Neste sentido, os Atlas Escolares, como qualquer outro recurso didático, devem respeitar a idade mental da criança e, assim, apresentar um conteúdo diversificado, numa forma apropriada, que possa ser aproveitado nos diferentes anos do Ensino Fundamental. Um outro aspecto, não menos importante, é considerar a formação atual dos professores, levando em conta suas opiniões e experiências.

Desse modo ao estruturar uma metodologia de Atlas Escolar para o conhecimento do Local, inicialmente, deve-se considerar a coexistência das dimensões da realidade, espaço e tempo, sobre o processo de apreensão e representação que ocorre na criança. Neste sentido, recomendam-se duas diretrizes básicas: o ensino do mapa e o ensino pelo mapa, levando-se em conta que, tanto dentro, como fora de tal constructo, emergem as duas citadas dimensões que perfazem a realidade.

Com relação ao ensino do mapa, considerando a dimensão espaço, toma-se como ponto de partida algumas noções básicas como, vizinhança, separação, ordem, inclusão e continuidade. A seguir, preparam-se os alunos para que sejam capazes de confeccionar mapas simples, de modo a representar a sua realidade próxima, empregando elementos cartográficos como símbolos, legenda, orientação, coordenadas e escala.

Por outro lado, levando em consideração a dimensão tempo, ainda no ensino do mapa, parte-se das noções de sucessão, duração e simultaneidade. Neste sentido, a preparação dos alunos deve ser tal que sejam capazes de representar a sua realidade próxima no tempo. Assim, recomenda-se a aplicação de exercícios 
sobre construção e interpretação de linhas do tempo e gráficos simples, como os de colunas.

Considerando o ensino pelo mapa, almeja-se que a criança resgate a informação contida no mapa. Assim, admitindo que a criança esteja alfabetizada cartograficamente, o ensino pelo mapa abarca três atividades principais: a leitura, a análise e a interpretação do mapa. Para tanto, recomenda-se que este processo comece pelo próprio bairro do aluno e que evolua até a totalidade-mundo. No entanto, o fato de se iniciar pelo local não significa ignorar a influência de outros municípios, de outros estados, do próprio país ou mesmo de outros países vizinhos ou não. Na verdade, a identificação das relações de outras cidades ou regiões com o município do aluno, durante o estudo de um mapa temático municipal, deve fazer parte do processo de ensino/aprendizagem da geografia com o emprego de mapas.

Com relação à organização de Atlas Geográficos Escolares Locais, devem ser definidos tanto o recorte espacial como o recorte temático. Por recorte espacial, entende-se a definição do tamanho e forma da região ou área que, em termos cartográficos, compreende a delimitação do seu contorno por coordenadas geográficas, segundo determinada escala e projeção. Por recorte temático, entendese o conjunto de temas considerados relevantes para o recorte espacial definido.

Para a elaboração de mapas temáticos, devem-se observar primeiramente as formas de manifestação dos fenômenos, de modo a que se associe a sua representação a pontos, linhas ou áreas como entes geométricos fundamentais. $A$ seguir, entende-se que a representação dos fenômenos seja realizada por meio de métodos específicos dessa elaboração. Uma vez selecionado o método de representação, pode-se elaborar um mapa de análise ou síntese, dependendo do nível de raciocínio escolhido nas representações. Finalmente, em função do número de fenômenos que se pretende representar, define-se para o mapa o seu nível de apreensão, que pode ser exaustivo ou não, sendo este último caracterizado pela coleção de mapas.

Com o propósito de implementar a metodologia proposta, elaborou-se um protótipo de Atlas Escolar para o município de Sorocaba-SP. Deve-se destacar que 
esta iniciativa é inédita para esta unidade administrativa, uma vez que até o momento da conclusão desta pesquisa, este município não dispunha de Atlas Escolar próprio.

Sorocaba, um município fundado em 1654, é notável pela sua importância econômica e política na história paulista e do Brasil, manifestada pela sua participação expressiva nos períodos do Bandeirismo, Tropeirismo e Industrialização. Atualmente, é um município de porte médio com 586.000 habitantes (IBGE, 2010). Por todos estes motivos, reunir os dados e as informações necessárias para confeccionar uma coleção de mapas temáticos, de modo a elaborar um Atlas Escolar que representasse o Local para o ensino e aprendizagem escolar, segundo a metodologia proposta, foi um desafio bastante complexo.

O protótipo do Atlas municipal de Sorocaba, com 136 páginas, reúne um capítulo inicial sobre Alfabetização Cartográfica, além de capítulos sobre História, Geografia e Ambiente. Dentro do tema História de Sorocaba, são abordados os períodos históricos mais significativos do município, além de tratar da própria evolução de desmembramentos territoriais paulistas, que compuseram o espaço sorocabano atual. Com relação à Geografia, foram incluídos 14 temas, tais como Relevo, Clima, População e Indústria. No capítulo do Ambiente, tratou-se do Saneamento Básico, Lixo e Reciclagem. Por fim, comparece o capítulo "Sorocaba em Zonas", onde se apresenta para cada uma das Zonas em que se divide o município - Norte, Sul, Leste, Oeste e Centro - as suas informações mais relevantes.

De modo a avaliar a adequação do Protótipo do Atlas ao seu público-alvo, professores e alunos do ensino fundamental, procedeu-se à sua avaliação em sala de aula. Tal avaliação ocorreu em duas Escolas Estaduais do município, sendo que

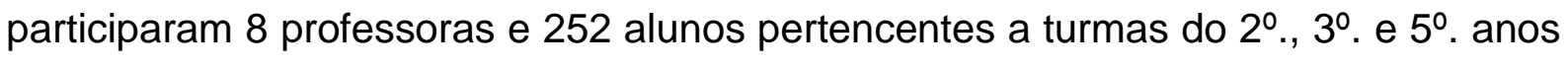
do Ensino Fundamental. As turmas dos 2․ e 3‥ anos trabalharam com atividades sobre o capítulo da Alfabetização Cartográfica. As turmas dos 5‥ anos, por sua vez, avaliaram os capítulos da História (Linha do Tempo) e da Geografia de Sorocaba (Relevo, Clima, Área urbana e rural, população, uso e cobertura do solo). 
Sob a ótica de uma pesquisa qualitativa, os resultados alcançados foram registrados por meio de gráficos, de modo a indicar o desempenho dos alunos frente às atividades propostas, extraídas do protótipo do Atlas. De forma geral, seu desempenho situou-se entre bom e satisfatório, revelando que a maioria dos alunos acertou mais de $50 \%$ das questões propostas.

As modificações adotadas nas pranchas temáticas, após a sua aplicação em sala de aula, foram decorrentes das sugestões das professoras, das dificuldades apresentadas pelos alunos e das observações da pesquisadora.

Fruto de uma ponderação geral sobre a pesquisa apresentada como tese de doutoramento pode-se considerar uma série de questões que merecerão uma reflexão mais apurada, ao mesmo tempo em que indicam soluções complementares.

A partir da afirmação de um leque de métodos de representação da cartografia temática concebido no final do século XIX, pode-se sempre discutir a validade de cada um em ser mais apropriado ou não às características e à forma de manifestação dos fenômenos considerados em cada tema a ser apresentado em mapa.

Assim, vale a pena tecer considerações, em particular sobre as representações dinâmicas e de síntese, que se fez questão que comparecessem no Atlas Escolar de Sorocaba.

As representações dinâmicas vão mostrar o dinamismo dos fenômenos ao longo do tempo. Este aspecto da realidade pode ser apreciado em termos qualitativos como quantitativos.

O atlas abordou as transformações que aconteceram no uso e ocupação da terra no município de Sorocaba estampando as situações de 1971 e de 2011, com o objetivo de proporcionar uma comparação entre os dois mapas e tentar demonstrar o que ocorreu no intervalo de 40 anos. Para tais representações adotou o método corocromático qualitativo, de relativa facilidade de leitura para os escolares. 
A parte difícil fica para a etapa da interpretação em termos de constatar quais importantes mudanças houve. Sem dúvida alguma a participação do professor aqui é indispensável.

Por sua vez as representações de síntese, por serem pouco exploradas nos livros didáticos e nos atlas, embora compareçam em alguns desses mapas, porém sem nenhum esclarecimento de que é um mapa diferente da maioria, geralmente analíticos.

O que se deseja com esta cartografia é chegar a uma representação integrada, holística, dentro de um raciocínio que entreviu a realidade como um todo coeso, onde a sociedade compõe com a natureza.

Assim, o mapa não mostra mais os elementos da realidade em estudo vistos em superposição ou em justaposição, mas, sim, a fusão deles em tipos. Isto quer dizer que o mapa delimitará conjuntos espaciais a partir do agrupamento de áreas unitárias de pesquisa, sendo caracterizados por agrupamentos de atributos e variáveis levados em conta na análise.

Outra representação digna de comentário é a que adotou o método das figuras geométricas proporcionais divididas para representar a população total, urbana e rural, segundo as zonas em que se estrutura o município de Sorocaba. Esta maneira de representar efetivos da população é bastante comum. O que deve ser dito acerca dela é o fato de exibir um resultado de superposição exaustiva, acumulando a representação dos totais com a respectiva representação das parcelas que os constituem, obrigando os pequenos leitores a fazerem um desdobramento da imagem para poderem ver os totais e as parcelas que os compõem.

O mapa sobre o clima de uma unidade administrativa também conta com sérias dificuldades, pois a concepção de clima é holística. O Clima diz respeito a como se percebe a sucessão dos tipos de tempo. Portanto é um mapa de síntese. Não se vêm mais representados os elementos climáticos como, pluviosidade, temperatura, pressão, ventos, frentes, etc., mas sim dois tipos de clima definidos 
por: Clima tropical com ventos de nordeste, alternadamente seco e úmido e Clima úmido com ventos de sudeste e entradas de ar polar.

A representação do relevo em mapa possui toda uma discussão à parte, pois se trata da aplicação do método isarítmico, adequado para fenômenos contínuos, portanto expresso mediante linhas de igual valor, no caso, as curvas de nível, entre as quais se intercala a sucessão das cores hipsométricas.

Embora de concepção complexa, foi escolhido de comum acordo com as professoras da escola onde se fizeram avaliações das páginas temáticas do Atlas, pelo fato de possibilitar trabalhar com a construção da respectiva maquete, facilitando a compreensão da realidade relevo representada no mapa.

A elaboração desta pesquisa possibilitou se pensar também no desdobramento de pesquisas complementares ou investigações completamente novas.

Uma primeira ideia de complementação seria a elaboração de um Manual do professor para o Atlas de Sorocaba apresentado como apêndice. Neste considerarse-ia um texto de fácil assimilação por parte do professor, para o encaminhamento do ensino e aprendizagem da Geografia com a participação dos mapas do atlas, além de incluir os respectivos exercícios para os seus alunos, os quais poderiam estar dispostos em um Caderno de atividades munido de um Guia para tanto.

Outra pesquisa com forte chamada para os momentos atuais seria a elaboração do mesmo atlas, acrescido das devidas possibilidades, em formato eletrônico.

Por fim, espera-se que esta pesquisa contribua com a divulgação da metodologia proposta, bem como com a documentação detalhada apresentada, servindo de referência para a elaboração de Atlas Escolares para outros municípios brasileiros.

Como temas para trabalhos futuros, sugere-se que: 
- se desenvolva, para o Atlas Municipal de Sorocaba-SP, um caderno de atividades e um manual do professor;

- se avalie o Atlas nos demais anos do Ensino Fundamental;

- se avalie o Atlas em Escolas Públicas Municipais e Escolas Particulares.

- se idealize também um atlas ilustrado e em formato eletrônico. 
REFERÊNCIAS 


\section{REFERÊNCIAS}

AGUIAR, Lígia M. B. O exercício da imaginação geográfica e a cartografia escolar: Práticas educativas com mapas através de atlas escolares municipais. Revista Geografares, n. 12, p. 258-288, 2012.

AGUIAR, Valeria T. B. Atlas geográfico escolar. 1996. 253 f. Tese (Doutorado em Geografia) - Universidade Estadual Paulista, Rio Claro, 1996.

Navegar, com mapas, é bem mais preciso! ALMEIDA, Rosângela, D. Novos caminhos da cartografia escolar: currículo, linguagem e tecnologia. (Org.). São Paulo: Contexto, 2011. 192 p.

Os atlas de Geografia: peso na mochila do aluno. Revista Geografia e Ensino, Belo Horizonte, v.6, n.1, p.39-42, mar. 1997.

ALMEIDA, Aluísio de. Sorocaba: 3 séculos de história. Sorocaba-SP: OTTONI, 2002. 415p.

ALMEIDA, Ary. Elementos de cartografia do atlas geográfico escolar: curso de férias para professores. Rio de Janeiro: IBGE, p. 197-202, 1968.

ALMEIDA, N. M. C.; PEREIRA, M. L. R. Os parâmetros curriculares nacionais e a geografia. In: SIMPÓSIO REGIONAL DE GEOGRAFIA, 2.,2003, Uberlândia. Anais...Uberlândia: Universidade Federal de Uberlândia, 2003. 13 p.

ALMEIDA, R. D. Integrando Universidade e Escola por meio de uma Pesquisa em Colaboração. 2001. f. Tese (Livre-Docência) - Universidade Estadual Paulista, São Paulo, 2001.

.(Org.). Novos rumos da cartografia escolar: currículo, linguagem e tecnologia. São Paulo: Contexto, 2011.192 p.

ALMEIDA, R. D; PASSINI, E. Y. O espaço geográfico: ensino e representação. São Paulo: Contexto, 1994.

.(Org.). Cartografia Escolar. São Paulo: Contexto, 2010. 224p.

ALMEIDA, R. D, SANCHEZ, M. C.; PICARELLI, A. Atividades cartográficas. São Paulo: Atual, v. 2, 38p.,1995.

ANDERSON, J. ; VASCONCELLOS, R. Mapas para e por crianças: possíveis contribuições dos cartógrafos. In: COLÓQUIO DE CARTOGRAFIA PARA CRIANÇAS, 1., 1995, São Paulo. Anais...LEMADI - USP; LEG-UNES: São Paulo, 1995. 
ANTUNES, A. R.; MENANDRO, H. F.; PAGANELLI, T. I. Estudos Sociais: teoria e prática. Rio de Janeiro: Access, 1993. 178p.

ARONOFF, S. Geographic information systems: a management perspective. Ottawa: DL Publications, 1989. 249p

ARTIMO, K. The bridge between cartographic and geographic information systems. In: MAC. EACHREN, A. Me TAYLOR, D. R. F. (Ed.). Visualization in modern cartography. Londres: Elsevier Science, 1994.

BALCHIN, W.G.V. “Graphicacy”. Geography, v.256, n.57, p.185-195, 1972.

BARBOSA, R.P. O sistema de atlas complexos de planejamento no Brasil. Revista Brasileira de Geografia, v.39, n.3, p.144-150, 1977.

BELLO, J. L. P. Educação no Brasil: a história das rupturas. Pedagogia em foco, Rio de Janeiro, 2001. Disponível em:<http://www.pedagogiaemfoco.pro.br/heb14.htm > Acesso em: 6/10/2012.

BERTALANFFY, L. von. General system theory: foundations, development, application. New York: George Braziller , 1968.

BERTIN, J. ; GIMENO, R. A lição de cartografia na escola elementar. Boletim Goiano de Geografia, Goiânia, v.2, n.1, p. 35 - 56, jan./jun., 1982.

BERTIN, J. La graphique et le traitement, graphique de l'information. Paris: Flammarion, 1977.

. La graphique. Comunications, Paris, v.15, p.169-185, 1970.

BOCHICCHIO, V. R. (Coord.) Manual de cartografia: atlas atual geografia. São Paulo: Atual,1993.

BONIN, S. Novas perspectivas para o ensino da cartografia. Boletim Goiano de Geografia, Goiânia, v.2, n.1, p.73-87, 1982.

BRASIL. Ministério da Educação. Secretaria de Educação Fundamental. Parâmetros Curriculares Nacionais: geografia. Brasília: MEC/SEF, 1988. 156p.

BRASIL. Ministério da Educação. Secretaria de Educação Fundamental. Parâmetros Curriculares Nacionais: geografia. Brasília: MEC/SEF, v.5, 2001.

BRASIL. Secretaria de Educação Fundamental. Parâmetros curriculares nacionais: história, geografia/ Secretaria de Educação Fundamental. Brasília MEC/SEF, 1997. 166p. 
CALLAI, H. C; CALLAI, J. L. Grupo, espaço e tempo nas séries iniciais. In: CASTROGIOVANNI, A. C. et. al. (Org.). Geografia em sala de aula: práticas e Reflexões. Porto Alegre: AGB, 1998, p.70.

CAMARGO, L. F. R.; FORTUNATO, M. R. Marcas de uma política de exclusão social para a América latina. In: TERRA LIVRE.13. DOSSIÊ: Os PCNs em discussão. São Paulo: A.G B., 1997, p. 20-29

CANDAU, V. M. Reformas educacionais hoje na América Latina. In: CURRícULO: políticas e práticas. Campinas: Papirus, p. 29-42, 1999.

CAPEL, H. Filosofia y ciencia en la geografia contemporánea. 2.ed. Barcelona: Barcanova, 1983, p.115.

CARLOS, A. F. A.; OLIVEIRA, A. U. (Orgs.). Reformas do mundo da educação: parâmetros curriculares e geografia. São Paulo: Contexto, 1999.

CARLOS, A. F. A. (Org.). Apresentando a metrópole na sala de aula. In: (Org.) A geografia na sala de aula. São Paulo: Contexto, 1999.

CARLOS, A. F. A. O consumo do espaço. In: Geografia. São Paulo: Contexto, 1999, p. 173-186. .(Org.). Novos caminhos da . O lugar no/do mundo. São Paulo: Hucitec, 1996.

CASTELLAR, Sonia. (Org.). Educação geográfica: teorias e práticas docentes. 2. ed. São Paulo: Contexto, 2007. 167 p. (Novas abordagens, Geousp, v. 5).

.A cartografia e a construção do conhecimento em contexto escolar. In: ALMEIDA, R.D. (Org.). Novos rumos da cartografia escolar: currículo, linguagem e tecnologia. São Paulo: Contexto, 2011. p. 121-135.

CASTRO, I. E. O problema da escala. In: CASTRO, I. E. et al. (Org.) Geografia: Conceitos e Temas. 2. ed. Rio de Janeiro: Bertrand Brasil, 2000.

CASTROGIOVANNI et al. (Org). Geografia em sala de aula: práticas e reflexões. Porto Alegre: AGB, 1998.

CEZAR. Adilson. História de Sorocaba: síntese. Uniso: Sorocaba, 2002, 73 p. il.

CEZAR. Adilson. (Coord.). Calendário. Sorocaba-SP: Paratodos, 2002. il. color.

CHERVEL, A. História das disciplinas escolares: reflexões sobre um campo de pesquisa. Teoria e Educação, v.2, 1990.

BOLIGIAN, L. e ALMEIDA, R.D. A cartografia nos livros didáticos no período de 1824 a 1936 e a história da geografia escolar no Brasil. In: ALMEIDA, R. D. (Org.). Novos 
rumos da cartografia escolar: currículo, linguagem e tecnologia. São Paulo: Contexto, 2011.

CLARY, M.; DUFAU, G.; DURAND, R.; FERRAS, R. Cartes et modèles à l'école. Montpellier: Reclus, 1987. $112 \mathrm{p}$.

CUNHA, Antônio Geraldo da; HOUAISS, Antônio. Dicionário histórico das palavras portuguesas de origem tupi. São Paulo: Melhoramentos, 1978. 357 p.

CRAMPTON, J.Maps as social constructions: power, communication, and visualization. Progress in Human Geography, v. 25, n. 2, p. 235-252, 2001.

CURY, C.R.J. A Educação Básica no Brasil. Educação e Sociedade, Campinas, vol.23, n.80, set.2002, p.168-200.

DAINVILLE, F. de. Le langage des géographes. Paris: Picard, 1964.

DAMIANI, A. L. A geografia e a construção da cidadania. São Paulo: Contexto, 1999. (A geografia na sala de aula).

DELAZARI, L. S; OLIVEIRA, L. C., Reflexões sobre atlas eletrônicos, Bol. Ciênc. Geod., Curitiba, v. 8, n. 2, p.79-91, 2002. Durban: ICA. 2003. Disponível em:<http://www.icaci.org/en/ICAStrategicPlan2003-08-16.pdf.>. Acesso em: 20 out. 2010. p. 17.

DIAS, M. H. Leitura e comparação de mapas temáticos em geografia. Lisboa: FLUL, 1988.

DODGE, M; KITCHIN, R.; PERKINS C. Rethinking maps: new frontiers in cartographic theory. Londres: Routledge, 2009.

DOURADO, L. F. Políticas e Gestão da Educação Básica no Brasil: limites e perspectivas. Educação e Sociedade, Campinas, vol.28, n.100, p.921-946, out. 2007.

DUARTE, P. A. Cartografia Temática. Florianópolis: Ed. da UFSC, 1991. . Fundamentos de Cartografia. Florianópolis: Ed. da UFSC, 1994, 16p. 
FEDERAL OFFICE OF TOPOGRAPHIC SWISSTOPO, National maps os Switzerland: digital and interactive, 2009 Disponível em: <http://www. Swisstopo.admin.ch /internet/swisstopo/en/home.html>. Acesso em: nov. 2010.

FELBEQUE, R. Atlas escolares: uma análise das propostas teórico-metodológicas. Boletim de Geografia (Maringá), n.2, p.36-41. 2001. Rio Claro, 2005. Tese (doutorado em Geografia) - IGCE, UNESP.

FERREIRA, G. M. L. Atlas geográfico: espaço mundial. São Paulo: Moderna, 1998.

FERREIRA, G. M. L. Geografia em mapas: O Estado de São Paulo. São Paulo: Ed. Moderna, 1995. 88p.

FERREIRA, G .M. L.; MARTINELLI, M. Os atlas geográficos para crianças: a alfabetização de sua linguagem. Revista Geografia e Ensino. Belo Horizonte, v.6, n.1, p.35-39, mar.1997.

FERREIFA, G. M. L. Moderno atlas geográfico. 5. ed. rev. e ampl. São Paulo: Moderna, 2011.

FERREIRA, G. M.L.; MARTINELLI, M. Atlas geográfico ilustrado. São Paulo: Moderna, 2004.

FONSECA, F. P.; OLIVA, J. T. A geografia e suas linguagens: o caso da cartografia. In: CARLOS. A. F. A. (Org.). A Geografia na sala de aula. São Paulo: Contexto, 1999.

FRANCISCHETT, M. N. A cartografia escolar crítica. Artigo aceito no GTD 05 do ENPEG2007. Disponível em: <http:www.uff.br/enpeg2007> Acesso em:26.05.2011.

FREITAS, M. I. C. A cartografia no ensino básico: experiências em cursos de formação continuada de professores. 2011. 203 f.Tese (Livre-Docência) Universidade Estadual Paulista, São Paulo, 2011.

(Org.). Cartografia e meio ambiente. Rio Claro: IBGE/UNESP, 2005. 177 p. il. color. (Série Cadernos Cecemca, v. 13).

FREITAS, M.I.C; YOKORO, C.M. A cartografia na Formação Continuada de Professores: mitos, medos e experiências vividas. In: ENCONTRO DE GEÓGRAFOS DA AMÉRICA LATINA, 12., 2009, Montevidéu, Uruguai. Anais eletrônicos....Montevidéu, Uruguai: Universidad De La república, 2009. Disponível em: <http.//egäl2009.easyplanners.info/buscar.php.> Acesso em: 03/12/2010.

FREITAS, M. R. ; GARCIA, L. B. R. Educação cidadã: propostas de materiais didáticos que unem os conceitos de tempo e espaço em sala de aula. Geografia Associação de Geografia Teorética - Rio Claro-SP, v. 28, n.2, p. 261-277, 2003. 
GALVÃO, M. V.; BARBOSA, R. P.; BOTELHO, C.C.; ALMEIDA, A. O plano mínimo para os atlas estaduais. In: SBC. CONGRESSO BRASILEIRO DE CARTOGRAFIA, 5.,1971 ,Rio de Janeiro: SBC.... Rio de Janeiro, 1971.

GEORGE, P. et al. A geografia ativa. São Paulo: DIFEL, 1969.

GIRARDI, Eduardo Paulon. Proposição teórico-metodológica de uma Cartografia Geográfica Crítica e sua aplicação no desenvolvimento do Atlas da Questão Agrária Brasileira. 2008. Tese (Doutorado em Geografia) - Faculdade de Ciências e Tecnologia, Universidade Estadual Paulista, Presidente Prudente, 2008.

GOMES, H. Espaço/Tempo em geografia. Boletim Goiano de Geografia.v.1-3, n.3, p. 105-134, 1983.

GROSSI, E. P. Proposta alternativa e análise crítica dos Parâmetros Curriculares Nacionais. n. 4, do mandato como Deputada Federal, 1996.

GUÉRIN, J. P. Géographie et représentation. In: André, Y. et alii. Représenter l'espace; l'imaginaire spatial à école. Paris : Anthropos, 1989. p. 3-5.

GUIRAUD, P. A semiologia. Lisboa: Presença, 1983.

GUMUCHIAN, H. Les représentations en géographie: définitions, méthodes et outils. In: ANDRÉ, Y. et al. Représenter l'espace: l'imaginaire spatial à l'école. Paris: Anthropos, 1989.

HÄGERSTRAND, T. Migration and area, Lund Studies in Geography, n.13, 1957.

Harley, J.B. Deconstructing the map. Cartographica, v.26, n.2, p. 1-20, 1989.

HARTSHORNE, R. Propósitos e Natureza da Geografia. São Paulo: Oscite, EDUSP, 1979.

HAYDT, 1997. Recursos Didáticos. Disponível em:

http://www.uemmg.org.br/list.noticia.php/origem/20/noticia/503/titulo/Recursos

Didáticos>. Acesso em: 15 nov. 2010.

HEIDEGGER, M. Ser e Tempo. Petrópolis: Vozes, 1987.

HOLANDA, V. Modernizações e espaços seletivos no nordeste brasileiro. Sobral: conexão lugar/mundo. (Tese Doutorado). São Paulo: ed. da autora, 2007.

HUBER, S; SCHMIDT, C. $2^{\text {nd }}$ Atlas of Switzerland: interactive concepts, functionality and techniques. Proc. of $21^{\text {st }}$ International Cartographic Conference (ICC), "Cartographic Renaissance", Durban, South Africa, 2003. 
IBGE. Atlas do censo demográfico 2000. Rio de Janeiro: IBGE, 2003.

Atlas geográfico escolar. 3. ed. Rio de Janeiro: IBGE, 2006.

. Primeiros_dados_divulgados. Disponivel em:

<http://www.censo2010.ibge.gov.br. $/>$ /index.php? uf $=35>$. Acesso em: 15-12-2010. Dados divulgados no Diário Oficial da União em: 04-11-2010.

ICA. ICA Strategic Plan 2003 - 2011. Durban: ICA, 2003.

ICA. Cartographic visualization. Enschede: ICA, 2001.

INEP - Instituto Nacional de Estudos e Pesquisas Educacionais. Disponível em: <http://www.inep.gov.br.. . Acesso em: fev. 2009.

INSTITUTO GEOGRÁFICO DE AGOSTINI. Atlante geográfico metódico de Agostini, 2006-2007. Novara: IGA, 2006.

INTERNATIONAL CARTOGRAPHIC ASSOCIATION. A strategic plan for the International Cartographic Association, 2003-2011: as adopted by the ICA General Assembly, 2003-08-16.

KOLACNY, A. Informação Cartográfica. Conceitos e termos fundamentais na Cartografia Moderna. Geocartografia: textos selecionados de cartografia teórica. GECART-FFLCH/USP, 1994, v. 2.

KRAAK, M-J. e ORMELING, F. Cartography: visualization of spatial data, 3. ed.. Harlow: Prentice Hall, 2010.

LACOSTE, Y. La géographie: ça sert d'abord, à faire la guerre. Paris : Maspero, 1976.

LAMA, J. P. La avispa y La odrquídea hacen mapa em el seno de um rizoma: cartografía y máquinas, releyendo a Deleuze y Guattari. Pró-Posições, v.20, n. 3, p. 121-145, 2009.

LASTORIA, A. C. A nova função do atlas na escola. Jornal de Piracicaba, Piracicaba, 31 mar.2002.

LASTORIA, A. C.; MELLO, R. C. Cotidiano e lugar: categorias teóricas da história e da geografia escolar. Universitas, Fernandinópolis, v. 4, p. 27-34, 2008.

LASTORIA, A. C. A cartografia escolar e a concepção de Atlas escolar municipal. Dialogus, Ribeirão Preto, v. 3, p. 111-126, 2007.

LASTORIA, A. C.; MIZUKAMI, M. G. N. Os processos de pensamento do professor, o ensino reflexivo e as teorias pessoais. Revista de ciências da educação, Lorena [São Paulo], v. 6, n. 10, p. 9-21, 2004. 
LASTORIA, A. C. (Org.). Atlas escolar histórico, geográfico e ambiental de Riberão Preto. Ribeirão Preto: [s. n.], 2008. v.1. 140 p.

LAWRENCE, V. Mapping out a digital future for ordnance Survey. The Cartographie journal. vol.39, n.1, p.77-80, jun. 2002.

LE SANN, Janine G. A caminho das noções básicas de geografia: uma proposta metodológica. Belo Horizonte: Dimensão, 2001. 2 v.

Atlas escolar de Lagoa da Prata. Belo Horizonte, 2002.

Atlas escolar de Padre Paraíso. Belo Horizonte, 2002.

Dar o peixe ou ensinar a pescar? Do papel do atlas no ensino fundamental. Revista Geografia e Ensino, Belo Horizonte, v. 6, n. 1, p.31-34, mar. 1997.

Geografia: elaborando um atlas municipal. Presença Pedagógica, Belo Horizonte, p. 47-55, maio/jun. 1995.

LE SANN, Janine G.; TORRES, M. E. L. de O. Q.; FERREIRA, S. A. Estudos sociais e geografia na escola primária: orientações metodológicas de 1a. a 4⿳亠丷a . Séries. Contagem: Littera Maciel, 1993.

LEMOS, Amália Inês G. de. (Org.). Turismo: impactos socioambientais. São Paulo: Hucitec, 1996. 305 p. il. (Geografia: teoria e realidade, n.31).

LESTEGÁS, F.R. La elaboración del conocimiento geográfico escolar: ¿ de la ciencia geografica a la geografía que se enseña o viceversa ? Íber - didáctica de las ciencias sociales: geografía e historia (Barcelona), n.24, abr. 2000. p.111.

LIBAULT, A. Tendências atuais da cartografia. Boletim Paulista de Geografia, v.44, n.5-14, 1967.

LOCH, R. N. Cartografia: representação, comunicação e visualização de dados espaciais. Santa Catarina: Ed. da UFSC, 2006.

LOPES, J. J. M. e VASCONCELLOS, T. de. Geografia da infância: reflexões sobre uma área de pesquisa. Juiz de Fora: FEME, 2005. p. 80.

MACEACHREN, A.M. How maps work: representation, visualization and design. New York: The Guilford Press, 1995.

MACEDO, E. F. Parâmetros Curriculares Nacionais: a falácia dos temas transversais. In: Currículo: políticas e práticas. Campinas: Papirus, p.43-58, 1999.

MACHADO-HESS, Elizabeth de Souza. Na busca de uma metodologia da cartografia temática para o trabalho com mapas em geografia. 2001. 198 p. Dissertação (Mestrado) - Faculdade de Filosofia, Letras e Ciências Humanas. Departamento de Geografia, Universidade de São Paulo, 2001. 
A cartografia na era da informação: infocartografia. GEOUSP (Espaço e Tempo), São Paulo, n. 06, p. 43-48, 1999.

.A criança diante do Atlas Escolar: mapas de análise e síntese. In: COLÓQUIO DE CARTOGRAFIA PARA CRIANÇAS, 3.,São Paulo. Anais... São Paulo: Departamento de Geografia / FFLCH-USP, 1999. p. 30-31.

. A dimensão social dos mapas. AGB Informa, v.65, n.2, p. 6, 1997.

. A linguagem do mapa: como entendê-la?. Temporis (Ação), Goiás, v. 2, n.

2, p.7-15, jun.1998.

. Infocartografía: desde los datos hasta la información. In: CONVENCIÓN TROPICO '99. Geografía, Meteorología y Agricultura Tropical. La Havana, Cuba, 1999.

MADEIRA, R. B. Linguagem, semiótica e comunicação. São Paulo: Ed. da Plêiade, 1996.

MAGNOLI, D. e SCALZARETTO. Atlas geopolítico. São Paulo: Scipione, 1996.

MAIO, A.C. di. Formação do professor e o ensino de cartografia: velhos e novos desafios. Boletim de Geografia [Maring], n.2, p.250-259, 2001.

Boletim de Geografia [Maringá], n. 2, p. 254.

MARQUES, A.J.; GALO, M.L.B.T. Escala Geográfica e Escala Cartográfica: distinção necessária. Bol. Geog., Maringá, v.26-27, n.1, 2008-2009, p.47-55.

Os atlas geográficos para crianças: a alfabetização de sua linguagem. Revista Geografia e Ensino, Belo Horizonte, v.6, n.1, p.35-39, mar. 1997.

MARTINELLI, M. Mapas da geografia e cartografia temática. 6. ed. ampl. atual. São Paulo: Contexto, 2011.

.Atlas geográficos para escolares: uma revisão metodológica. In: ALMEIDA, R.D. (Org.). Novos rumos da cartografia escolar: currículo, linguagem e tecnologia. São Paulo: Contexto, 2011.

As representações gráficas da geografia: os mapas temáticos. Tese de Livre-Docência, USP/FFLCH-DG, São Paulo: Edição do autor, 1999.

. Cartografia temática: caderno de mapas. São Paulo: EDUSP, 2003. 
. Dos atlas impressos aos atlas eletrônicos: perspectivas para uma nova cartografia infantil? In: COLÓQUIO DE CARTOGRAFIA PARA CRIANÇAS, 3,1999 ,SÃO PAULO. Anais... São Paulo: AGB/USP, 1999.

. Gráficos e mapas, construa-os você mesmo. São Paulo: Moderna, 1998. $120 \mathrm{p}$.

Atlas geográfico: natureza e espaço da sociedade. São Paulo: Ed. do Brasil, 2003.

- Cartografia dinâmica: espaço e tempo nos mapas. Geousp: espaço e tempo, v.18, p.53-66, 2005.

. As cartografias e os atlas geográficos escolares. Revista da ANPEGE, v. 7 , n.1, número especial, p.251-260, out. 2011.

O ensino da cartografia temática. IN: CASTELLAR, S. (Org.). Educação geográfica: teorias e práticas docentes. São Paulo: Contexto, 2005.

Representações gráficas: mapas e gráficos na geografia. In: PROJETO ARARIBÁ. Informes e documentos: geografia. São Paulo: Moderna, 2006.

. Um atlas geográfico escolar para o ensino-aprendizagem da realidade natural e social. Portal da Cartografia. Londrina, v.1, n.1, p.21-34, maio/ago. 2008.

MARTINELLI, M.; FERREIRA, Graça M. L. A Cartografia para os atlas geográficos para crianças. In: COLÓQUIO DE CARTOGRAFIA PARA CRIANÇAS,1., 1995, Rio Claro. Anais... Rio Claro: UNESP/USP, 1995. p. 37-40.

MATIAS, L. F. Por uma cartografia geográfica: uma análise da representação gráfica na geografia. 1996154 f. (Dissertação de mestrado). São Paulo: Faculdade Filosofia, Letras e Ciências Humanas DG-USP, 1996.

MELHORAMENTOS/IBGE. Atlas Geográfico Melhoramentos. Brasil. São Paulo, Cia. Melhoramentos de São Paulo, 1998.

MENEGUETTE, Arlete A.C. Atlas interativo do Pontal do Paranapanema: uma contribuição à educação ambiental. 2001. Tese (Livre Docência em Cartografia) UNESP, Presidente Prudente, 2001.

MIRANDA, Leodete; AMORIM, Leonice. Atlas geográfico de Mato Grosso. Cuiabá: Entrelinhas, 2001.

MORAES, A.C.R. Geografia. Pequena história crítica. São Paulo, Hucitec, 1995. 
Hucitec, 1993.

; COSTA, W.M. Geografia crítica: a valorização do espaço. São Paulo:

MOLES, A. e ROHMER, E. Psychologie de l'espace. Tournai: Gastermann, 1972.

MORAES, L B. A cidade em mapas: Goiânia e sua representação no ensino de geografia. Goiânia: Vieira, 2008. 171 p. (Ensaios temáticos).

MOREIRA, R. O que é geografia. São Paulo: Brasiliense, 1988.

MOREIRA, Antonio Flávio; SILVA, Tomaz Tadeu da (Orgs). Currículo, Cultura e Sociedade, SP: Cortez, 2001.

MORGAN, C. A magia dos mapas. Seleções do Readers Digest, Lisboa, tomo 37, n. 222, 1989.

NAHUM, E. P. Mapas Brasil: regiões brasileiras. Série Cadernos, São Paulo: Scipione, 1988.

NARSKIKH, R. S. O atlas escolar geográfico brasileiro. Boletim Geográfico, Rio de Janeiro, v.21, n.174, p.325-329, maio/jun. 1963.

NETO, A. T. Haverá, também, uma semiologia gráfica? Boletim Goiano de Geografia. Goiânia, v. 4-6 n. 1-2,UFG: Cegraf, 1984-86.

NETTO, J. T. C. Semiótica, informação e comunicação. São Paulo: Perspectiva, 1989.

NICOLETTI, Fabiana et al. ALMEIDA, Rosângela Doin de. (Org.). Atlas municipal escolar - Rio Claro: geográfico, histórico, ambiental. Rio Claro: UNESP - Rio Claro, 2002. 113 p. il. color.

NIMER, E.; O’NEILL, M.M.; CORRÊA R.L. Projeto Atlas Nacional do Brasil: a concepção teórica. Revista Brasileira de Cartografia, v. 50, n.3, p.151-155, 1988.

NUÑES, J. J. R. Ideas para el uso de las Caras de Chernoff en La Cartografia Escolar. Bol. Geogr., Maringá, v.28, n.1, 2010, p.5-15.

OLIVEIRA, C. Curso de cartografia moderna. Rio de Janeiro: IBGE, 1988.

OLIVEIRA, L. Estudo metodológico e cognitivo do mapa. São Paulo: USP-IG, 1978. 
. Estudo metodológico e cognitivo do mapa. In:, ALMEIDA, R. D. (Org.). Cartografia Escolar. 2. ed. São Paulo: Contexto, 2010.

OLIVEIRA, A. R.; ALMEIDA, R. D. O estudo da localidade através de atividades com mapas municipais no ensino fundamental. In: COLÓQUIO DE CARTOGRAFIA PARA CRIANÇAS, 1999, São Paulo. Anais... São Paulo: AGB/USP, 1999. p. 35-36.

OLIVEIRA, A. R.; ALMEIDA, R. D. O estudo da localidade através de atividades com mapas municipais no ensino fundamental. COLÓQUIO DE CARTOGRAFIA PARA CRIANÇAS, 3., Anais... São Paulo: AGB/USP, 2000, $158 \mathrm{p}$.

OLIVEIRA, Livia. A construção da noção de concentração territorial por alunos de $1^{\circ}$ grau. Orientação. v. 6, p. 5-20, nov. 1985.

OLIVEIRA, R. M. O saber cartográfico e o exercício do poder. In: ENCONTRO DE CARTOGRAFIA DO NORDESTE, 1.,1987, Recife. Anais... Recife, 1987.

PAGANELLI, T. I. Da Representação do Espaço ao Espaço da Representação. In: COLÓQUIO DE CARTOGRAFIA PARA CRIANÇAS. Rio Claro, Anais...: Rio Claro, 1995.

PAGANELLI, T. I. et al. Estudos sociais: teoria e prática. Rio de Janeiro: ACCESS, 1993.

et al. A noção do espaço e do tempo: o mapa e o gráfico. Orientação, v.6, p. 21-33, 1985.

PARREIRAS, Elza M. M. F.; RODRIGUES, Janete O. Elaboração de atlas geográfico: uma metodologia de trabalho. In: CONGRESSO BRASILEIRO DE CARTOGRAFIA, 13, 1987, Brasília. Anais... Brasília: SBC, 1987. p. 573-579.

PASSINI, E. Y. Alfabetização cartográfica e o livro didático: uma análise crítica. Belo Horizonte: Lê, 1994.

PASSINI, E. Y.; PEZZATO, J. P. Discussão sobre a metodologia da alfabetização cartográfica ou metodologia para leitura/compreensão de mapas pela criança. In: COLÓQUIO DE CARTOGRAFIA PARA CRIANÇAS, 3.,1999, São Paulo. Anais... São Paulo: AGB/USP. 1999. p. 14-22.

PELETEIRO, M. et. al. La lectura del mapa del atlas en el 3er. ciclo de la escuela primaria. In: CONGRESO INTERNACIONAL SOBRE COMUNICACIÓN, TECNOLOGÍA Y EDUCACIÓN, 2. Livro de actas, 1998, p.313-318. 
PENTEADO, H. D. (Org.), Pedagogia da comunicação: teorias e práticas. São Paulo: Cortez, 1998.

PESSOA, Rodrigo Bezerra. Um olhar sobre a trajetória da geografia escolar no Brasil e a visão dos alunos de ensino médio sobre a geografia atual. 2007. 130 f. Dissertação (Mestrado) - Universidade Federal da Paraíba. Paraíba, 2007.

PEREIRA, R. M. F. A. Da gênese que se ensina à gênese da geografia moderna. 3. ed. Florianópolis: Ed. da UFSC, 1999, p.36-37.

PEREIRA, R. M. F. A. Da geografia que se ensina à gênese da geografia moderna. 2. ed. Florianópolis: Ed. da UFSC, 1993, p. 36-7.

PETCHENIK, B.B. Cognition in cartography. Cartographica Monograph, v.14, p.117-128, 1997.

Fundamental considerations about atlases for children. Cartographica, v. 24 n.1, p.16-23, 1987.

PIAGET, J. Formação do simbolismo na criança. Rio de Janeiro: Zahar, 1974.

PIAGET, J. \& INHELDER, B. A representação do espaço na criança. Trad. Bernardina Machado de Albuquerque. Porto Alegre: Artes Médicas, 1993. 507p.

PICARELLI, A.; SANCHEZ, M. C. ;ALMEIDA, R. D. Coleção atividades cartográficas. São Paulo: Atual, 1995.

PIÑEIRO PELETEIRO, M. R. e MELÓN ARIAS, M. C. El papel del atlas en la enseñanza. Íber [Barcelona], n. 13, p. 37-45, 1997.

POIDEVIN, D. La carte moyen d'action: conception - réalisation. Paris: Ellipses, 1999.

PONTUSCHKA, Nídia Nacib. Parâmetros Curriculares Nacionais: tensão entre Estado e escola. In: Carlos, A. F. A. \& Oliveira, A. U. De (Org.). Reformas do Mundo da Educação - Parâmetros Curriculares e Geografia, GEOUSP 2. Novas abordagens, São Paulo: Contexto, 1999.

PREFEITURA MUNICIPAL DE SOROCABA. Secretaria de Educação e Cultura. Divisão de Cultura. Tropeirismo. Sorocaba: PMS, [2008]. 
PREFEITURA DO MUNICÍPIO DE SÃO PAULO. (São Paulo). Secretaria Municipal de Educação. Geografia, [São Paulo]: Ed. da UNESP, [200-]. 28 p. il. color. (Centro Municipal de Ensino Supletivo, v.2).

RACINE, J.B. et al. Escala e ação, contribuições para uma interpretação do mecanismo de escala na prática da geografia. Revista Brasileira de Geografia, v.45, n.1, p.123-135, 1983.

RAISZ, E. Cartografia Geral. 2 de., Rio de Janeiro: Científica, 1964, 414 p.

RATAJSKI, L. Metodyka Kartografii Spoleczno-gospodarczej. Warszawa: PPWK, 1989.

REDE NACIONAL DE FORMAÇÃO CONTINUADA DE PROFESSORES. São

Paulo: Cecemca-unesp.Disponível:em:

$<$ http://cecemca.rc.unesp.br/cecemca/curso ead/cursos ead.htm.> acesso em 27/04/2011.

ROBINSON, A.H. e SALE, R.D. Elements of cartography. 3. ed. New York: John Wiley \& Sons, 1969.

RUA, João et al. Para ensinar geografia: contribuição para o trabalho com $1^{\circ}$ e $2^{\circ}$ graus. Rio de Janeiro: ACCES, 1993. 311 p. il.

SALICHTCHEV, K. A. Cartografía. La Habana: Pueblo y Educación, 1979.

SANTOS, M. A Natureza do Espaço. Técnica e Tempo. Razão e Emoção. SP: Hucitec, 1996.

SANTOS, M. Técnica, espaço, tempo: globalização e meio técnico - científico informacional. São Paulo: Hucitec, 1994

. Espaço e método. São Paulo: Nobel, 1997.

. O trabalho do geógrafo no terceiro mundo. São Paulo: Hucitec, 1996.

. Pensando o espaço do homem. São Paulo: Hucitec, 1982.

Por uma economia política da cidade. São Paulo: Hucitec, 1994. 
Por uma geografia nova. São Paulo: Hucitec, 1996.

- Técnica, espaço, tempo: globalização e meio técnico - científico informacional. São Paulo: Hucitec, 1994.

. Da totalidade ao lugar. São Paulo: EDUSP, 2005, p. 27.

O retorno do território. In. SILVEIRA, M. L. De et al. (Org.). Território, globalização e fragmentação. 3. ed. São Paulo: Hucitec,1996.

- Por uma outra globalização: do pensamento único à consciência universal. Rio de Janeiro: Record, 2000.

SANTOS, M. M. D. dos. A representação gráfica da informação geográfica. Geografia, v.12, n.23, p. $1-14,1987$.

SANTOS, M. M. D. dos. O uso do mapa no ensino-aprendizagem da geografia. Geografia, v. 16, n. 1, p. 1-22, 1991.

SANTOS, V. L. Cartografia temática e seu desenvolvimento: algumas considerações. In: CONGRESSO BRASILEIRO DE CARTOGRAFIA, 15.1991. Anais... 1991. v. 2, p. 357-362.

SARACENI, Vínicius. (Dir.). Atlas ambiental: Bebedouro - SP. São Paulo: Vistadivina, 2008. 105 p. il. color.

SAUSEN, Tânia Maria. Cartografia na escola. PGM 5 - Cartografia e Novas tecnologias. Salto para o futuro/TV Escola. Disponível em: $<$ http://www.tvebrasil.com.br/salto $>$. Acesso em: 05 mai. 2008.

SAVIANI, D.O plano de desenvolvimento econômico da educação: análise do projeto do MEC. Educação e Sociedade, Campinas, vol.28, n.100, p.1231-1255, out. 2007.

SILVA, J. A. da e FREZZA, J. S. "A construção das noções de espaço e tempo nas crianças do ensino fundamental”. Cojectura, v.15, n.1, p.45-53, 2010.

SILVA, J.L.B. da. O que está acontecendo com o ensino de Geografia?Primeiras Impressões. In: PONTUSCHKA, N. N.; OLIVEIRA, A. V. de (Orgs). Geografia em perspectiva. São Paulo: Contexto, 2002.

SILVA, M.A.B. da O Atlas escolar municipal de Sena Madureira - AC. Boletim de Geografia, [Maringá] n.2, p. 151-156. 2001. 
SILVA, T. T. Documentos de identidade: uma introdução às teorias do currículo. 2. ed. Belo Horizonte: Autêntica, 2004.

SILVA, T. T. Documentos de identidade: uma introdução às teorias do currículo. 2. ed. Belo Horizonte: Autêntica, 2004.

SIMIELLI, M. E. R. O mapa como meio de comunicação: implicações no ensino de geografia do 1ำ grau. São Paulo: FFLCH/DG-USP, 1986.

SIMIELLI, M. H. Primeiros Mapas: como entender e construir. 3. ed. São Paulo: Ática, 1995. 4 vol.

SIMIELLI, M. R. Cartografia no ensino fundamental e médio. São Paulo: Contexto, 1999. (A Geografia na sala de aula).

SIMIELLI, M. Elena R. Comunicação cartográfica e o atlas geográfico escolar. In: CONGRESSO BRASILEIRO DE CARTOGRAFIA, 11., 1983, São Paulo. Anais... São Paulo: SBC, 1983. p. 269-277.

. Atlas geográfico escolar. São Paulo: Ática, 2001.

. Geoatlas. 32. ed. São Paulo: Ática, 2006.

SCHWARTZMANN, S.; BROCK, C. (Ed.) Os desafios da educação no Brasil. Rio de Janeiro: Nova Fronteira, 2005.

SLOCUM, T.A.; MCMASTER, R.B.; KESSLER,F.C.; HOWARD, H.H. Thematic cartography and geovisualization. 3. ed. Upper Saddle River: Pearson Prentice Hall, 2009.

SMITH, Welber Senteio. Os peixes do Rio Sorocaba. A história de uma bacia hidrográfica. Sorocaba, SP: TCM - Comunicação, 2003, 160 p.; il.

SOARES, M. Letramento: um tema em três gêneros. Belo Horizonte: Autêntica, 2002.

SOTO, A.G.M. e LÓPEZ, M.O. Análisis y síntesis en cartografía: algunos procedimientos. Bogotá: Universidad Nacional de Colombia, 2005.

SOUZA, J. G. A cartografia e o movimento de renovação da geografia brasileira. Geosul, n. 18, Ano 9, 2 sem. 1994. 
SPÓSITO, E. S. A vida nas cidades. São Paulo: Contexto, 1994.

STEFAN, H., RENÉ, S., MARIANNE, R., LOREZ, H. Multivariate Mapping in High Quality Atlases. Institute of Cartography, Switzerland: ETH Zurich, [200?].

STRAFORINI, R. Ensinar geografia: o desafio da totalidade-mundo nas séries iniciais. (2ª Ed.). São Paulo: Annablume, 2008. 188 p.

TARDIF, M. Saberes docentes e formação profissional. Tradução de: Francisco Pereira. 10 ed. Petrópolis: Vozes , 2010. 325p.

TAYLOR, D.R.F. Some new applications in the theory and practice of cybercartography: mapping with indigenous people in Canada's north, Conference Proceedings: $\mathbf{2 4}^{\text {th }}$ International Cartographic Conference, Santiago de Chile: ICC, 2009.

A conceptual basis for cartography: new directions for the information era. The Cartographic Journal, Enschende, ITC, v.28, 1991, p.214.

. Perspectives in visualization and modern cartography. In: MACEACHREN, M. e TAYLOR, F. (Ed.). Visualization in modern cartography. Londres. Elseiver Science Ltd., 1994.

. Some new applications in the theory and practice of cybercartography:

mapping with indigenous people in Canada's north, Conference Proceedings: $24^{\text {th }}$ International Cartographic Conference, Santiago de Chile: ICC, 2009.

THIOLLENT, M. Metodologia da pesquisa-ação. São Paulo: Cortez, 2005.

TSUJIOKA, Helena M.F.D. et al. PASSINI, Elza Yasuko. (Org.) Alfabetização cartográfica: vivência de uma pesquisa - ação crítico colaborativa. Maringá: Eduem, 2009. 69 p. il. color. (Coleção Fundamentos, n. 53)

TUAN, Y. Topofilia: um estudo da percepção, atitudes e valores do meio ambiente. Rio de Janeiro: DIFEL, 1980.

VASCONCELLOS, R.; ANDERSON, J. A linguagem cartográfica. Dom Bosco Informa, Piracicaba, 01 out. 2001.

VESENTINI, J. W. Geografia, Natureza e Sociedade. São Paulo: Contexto, 1989. 
VESENTINI, J. W. Educação e ensino de Geografia: instrumentos de dominação e/ou de libertação. In: CARLOS, A. F. A. (Orgs.). A Geografia na sala de aula. São Paulo: Contexto, 1999.

VIDAL de LA BLACHE, P. Princípios de geografia humana. Lisboa: Cosmos, 1956.

VIEIRA, E.F.C. Produção de material didático utilizando ferramentas de geoprocessamento. Minas Gerais: UFMG (Monografia), 2001.

VIEIRA, N.M. A linguagem gráfica no processo ensino-aprendizagem da história. Franca: FHDSS, 1988.

VLACH, V. \& VESENTINI, J. W. Geografia crítica: o espaço social e o espaço brasileiro. São Paulo: Ática, 1996. v.2.

VYGOTSKY, L.S. A construção do pensamento e da linguagem. São Paulo: Martins Fontes, 2009.

WALLON, H. Psicologia e educação da criança. Lisboa: Vega Universidade, 1979.

WIEGAND, P. (Ed.). Oxford student atlas. Oxford: Oxford University Press, 2002.

Learning and teaching with maps. London: Routledge, 2006.

WURMAN, R. S. Ansiedade de Informação: como transformar informação em compreensão. São Paulo: Cultura, 1991. 


\title{
APÊNDICE
}

\author{
APÊNDICE A - ATLAS ESCOLAR DE \\ SOROCABA - SP - HISTÓRIA, GEOGRAFIA \\ E AMBIENTE. ANOS INICIAIS DO ENSINO \\ FUNDAMENTAL
}

